UNITED STATES DEPARTMENT OF THE INTERIOR

J. A. Krug, Secretary

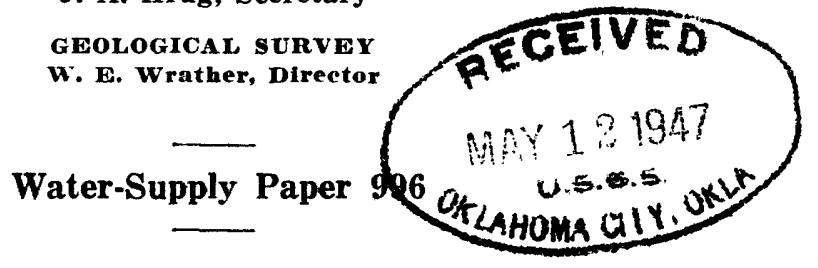

\author{
GEOLOGIC FEATURES OF THE \\ CONNECTICUT VALLEY, MASSACHUSETTS \\ AS RELATED TO RECENT FLOODS
}

BY

RICHARD H. JAHNS

Prepared in cooperation with the COMMONWEALTH OF MASSACHUSETTS DEPARTMENT OF PUBLIC WORKS
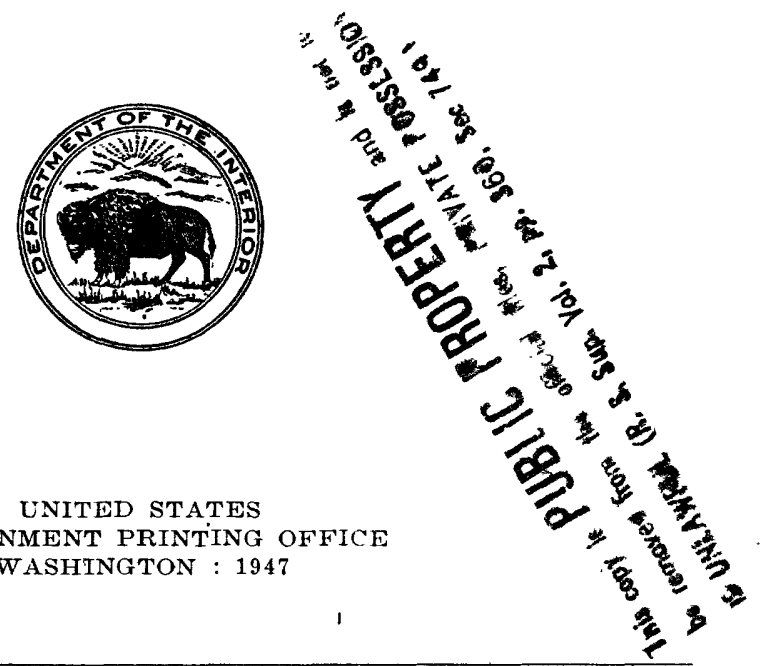

UNITED STATES IOVERNMENT PRINTING OFFICE WASHINGTON : 1947

For sale by the Superintendent of Documents, U. S. Government Printing Office, Washington 25 , D. C.

Price $\$ 1.75$ 


\section{CONTENTS}

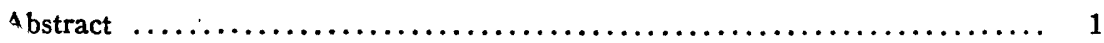

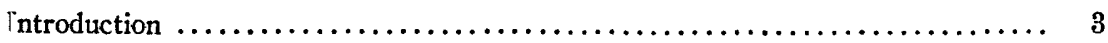

Purpose and scope of investigations $\ldots \ldots \ldots \ldots \ldots \ldots \ldots \ldots \ldots \ldots \ldots, \mathbf{3}$

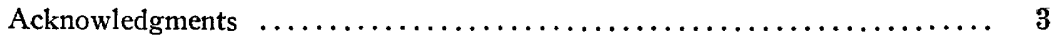

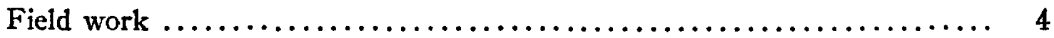

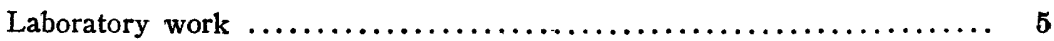

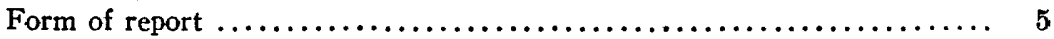

Jeneral features of the Connecticut Valley drainage basin in Massachusetts.... 6

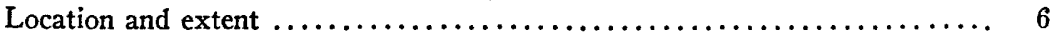

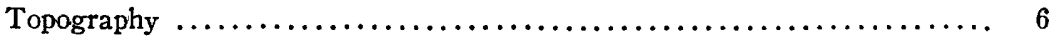

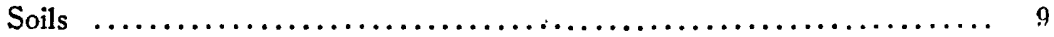

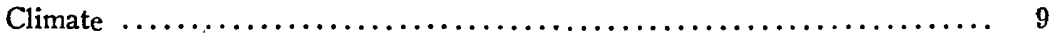

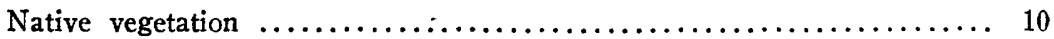

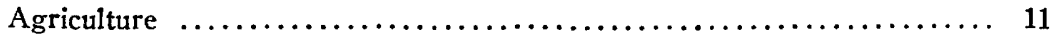

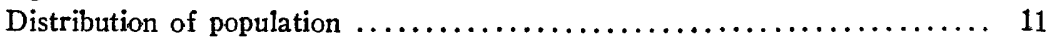

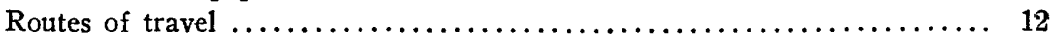

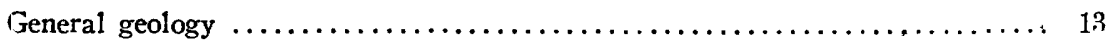

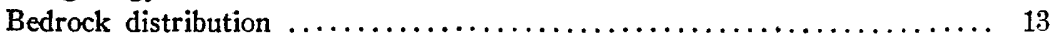

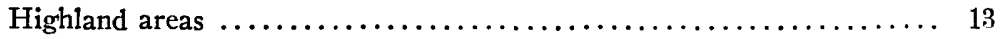

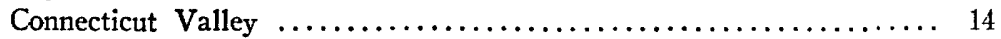

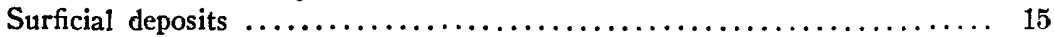

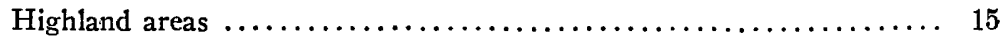

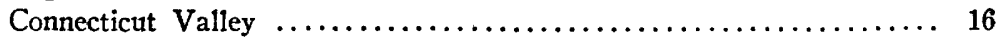

Physiographic development of the Connecticut Valley in Massachusetts ....... 17

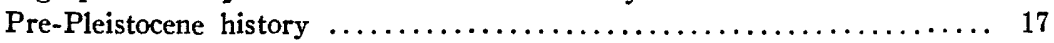

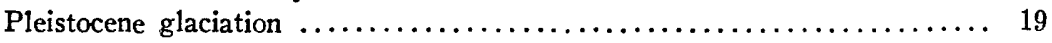

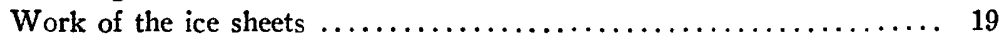

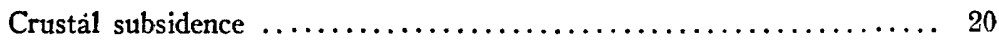

Disappearance of the last ice sheet $\ldots \ldots \ldots \ldots \ldots \ldots \ldots \ldots \ldots \ldots \ldots, 21$

Formation of high terraces $\ldots \ldots \ldots \ldots \ldots \ldots \ldots \ldots \ldots \ldots \ldots, 21$

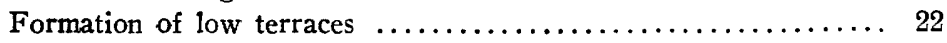

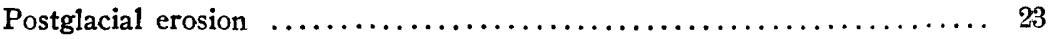

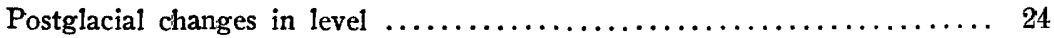

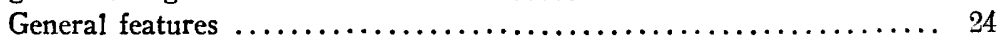

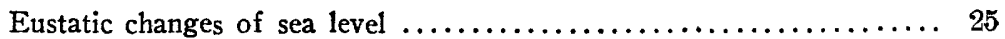

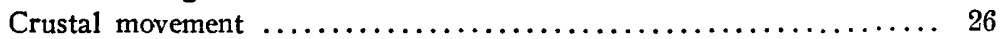

Changes of level in the Connecticut Valley .................. 27

Development of the postglacial Connecticut River .................. 29

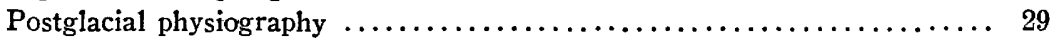

Establishment of a postglacial course $\ldots \ldots \ldots \ldots \ldots \ldots \ldots \ldots \ldots, 29$

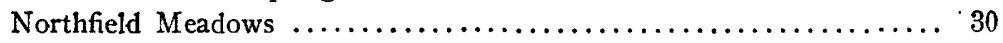

Turners Falls Gorge $\ldots \ldots \ldots \ldots \ldots \ldots \ldots \ldots \ldots \ldots \ldots \ldots \ldots \ldots \ldots, 30$

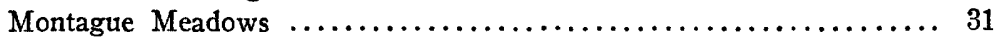

Hadley-Hatfield Meadows $\ldots \ldots \ldots \ldots \ldots \ldots \ldots \ldots \ldots \ldots \ldots \ldots \ldots . \ldots \ldots$

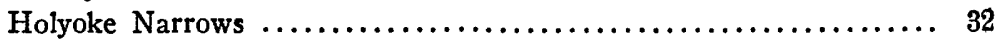

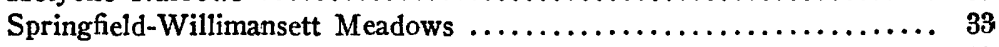

Summary of postglacial physiography $\ldots \ldots \ldots \ldots \ldots \ldots \ldots \ldots \ldots \ldots, 33$ 
Development of the postglacial Connecticut River-Continued. . Page

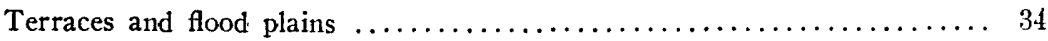

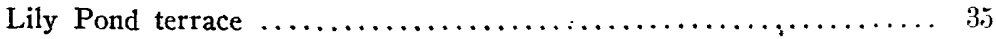

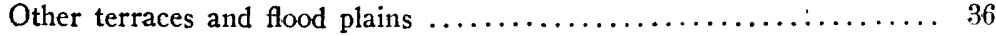

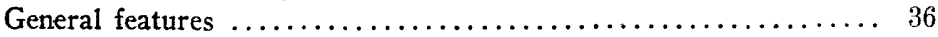

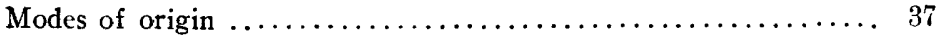

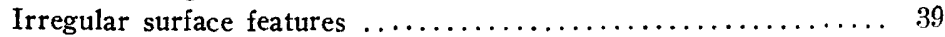

Terrace and flood-plain distribution $\ldots \ldots \ldots \ldots \ldots \ldots \ldots \ldots \ldots \ldots \ldots$

Northfield Meadows ........................... 40

Gorge areas ............................. 40

Other meadow areas $\ldots \ldots \ldots \ldots \ldots \ldots \ldots \ldots \ldots \ldots \ldots \ldots \ldots \ldots$ 4n

Tributary terraces and flood plains $\ldots \ldots \ldots \ldots \ldots \ldots \ldots \ldots \ldots \ldots \ldots$

Causes of normal river-terrace development $\ldots \ldots \ldots \ldots \ldots \ldots \ldots \ldots \ldots \ldots$

Connecticut River terraces $\ldots \ldots \ldots \ldots \ldots \ldots \ldots \ldots \ldots \ldots \ldots \ldots \ldots \ldots$

Meanders and oxbows $\ldots \ldots \ldots \ldots \ldots \ldots \ldots \ldots \ldots \ldots \ldots \ldots \ldots \ldots \ldots \ldots$

Flood-plain and terrace deposits $\ldots \ldots \ldots \ldots \ldots \ldots \ldots \ldots \ldots \ldots \ldots \ldots$

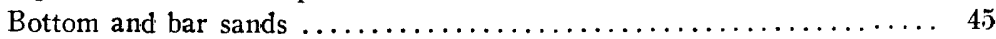

Lower flood-plain sequence $\ldots \ldots \ldots \ldots \ldots \ldots \ldots \ldots \ldots \ldots \ldots \ldots \ldots \ldots$

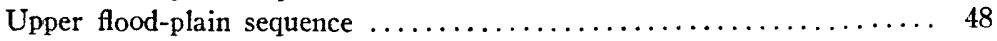

Recent flood deposition $\ldots \ldots \ldots \ldots \ldots \ldots \ldots \ldots \ldots \ldots \ldots \ldots \ldots \ldots$

Summary of Connecticut River terraces and flood plains........... 50

Characteristics of the Connecticut River and its tributaries $\ldots \ldots \ldots \ldots \ldots \ldots \ldots$

Connecticut River $\ldots \ldots \ldots \ldots \ldots \ldots \ldots \ldots \ldots \ldots \ldots \ldots \ldots \ldots \ldots \ldots \ldots \ldots \ldots$

Channel characteristics $\ldots \ldots \ldots \ldots \ldots \ldots \ldots \ldots \ldots \ldots \ldots \ldots \ldots \ldots \ldots$

Lateral channel control $\ldots \ldots \ldots \ldots \ldots \ldots \ldots \ldots \ldots \ldots \ldots \ldots \ldots \ldots \ldots$

Principal tributaries $\ldots \ldots \ldots \ldots \ldots \ldots \ldots \ldots \ldots \ldots \ldots \ldots \ldots \ldots \ldots \ldots \ldots \ldots$

Flood-inundation cycle $\ldots \ldots \ldots \ldots \ldots \ldots \ldots \ldots \ldots \ldots \ldots \ldots \ldots \ldots \ldots \ldots$

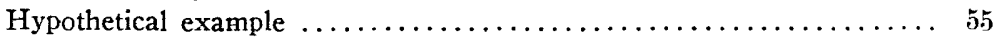

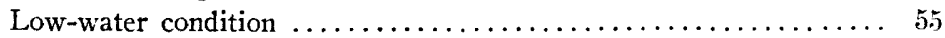

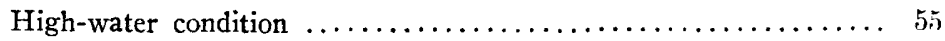

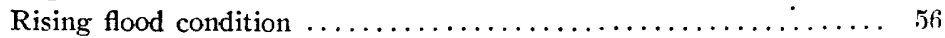

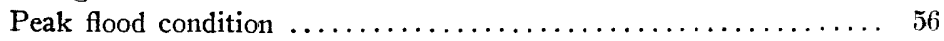

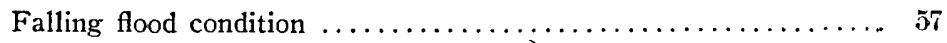

General features of the 1936 and 1938 floods $\ldots \ldots \ldots \ldots \ldots \ldots \ldots \ldots \ldots \ldots$

Flood of March $1936 \ldots \ldots \ldots \ldots \ldots \ldots \ldots \ldots \ldots \ldots \ldots \ldots \ldots \ldots$

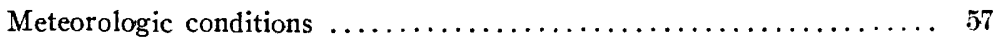

Nature of the flood $\ldots \ldots \ldots \ldots \ldots \ldots \ldots \ldots \ldots \ldots \ldots \ldots \ldots \ldots \ldots$

Flooded areas $\ldots \ldots \ldots \ldots \ldots \ldots \ldots \ldots \ldots \ldots \ldots \ldots \ldots \ldots \ldots \ldots$

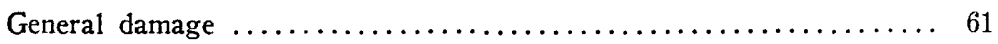

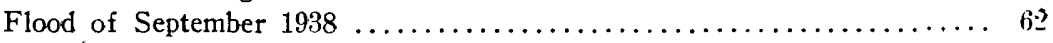

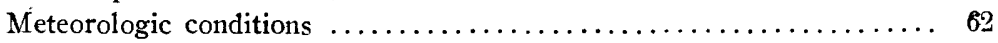

Nature of the flood $\ldots \ldots \ldots \ldots \ldots \ldots \ldots \ldots \ldots \ldots \ldots \ldots \ldots \ldots$

Flooded areas $\ldots \ldots \ldots \ldots \ldots \ldots \ldots \ldots \ldots \ldots \ldots \ldots \ldots \ldots \ldots \ldots \ldots$

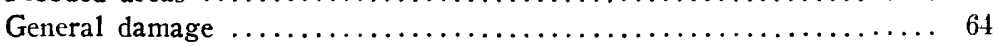

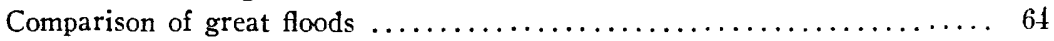

Erosional effects of the 1936 and 1938 floods $\ldots \ldots \ldots \ldots \ldots \ldots \ldots \ldots \ldots \ldots \ldots \ldots \ldots \ldots \ldots$

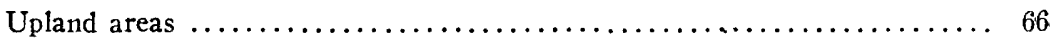

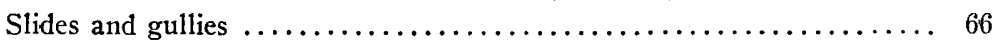

Channel and flood-plain erosion $\ldots \ldots \ldots \ldots \ldots \ldots \ldots \ldots \ldots \ldots \ldots$

Channel diversion $\ldots \ldots \ldots \ldots \ldots \ldots \ldots \ldots \ldots \ldots \ldots \ldots \ldots \ldots \ldots \ldots$

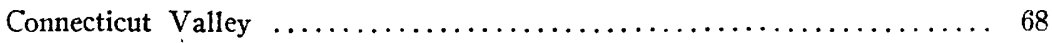

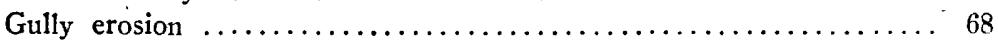


Erosional effects of the 1936 and 1938 floods-Continued.

Connecticut Valley-Continued. . Page

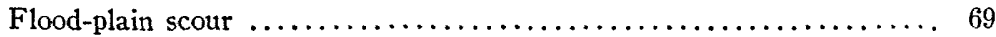

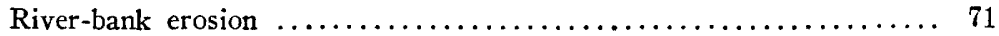

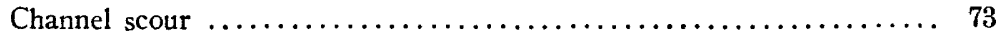

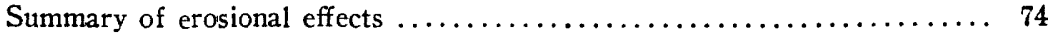

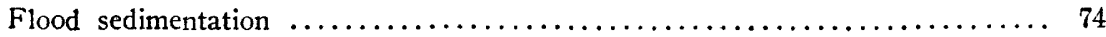

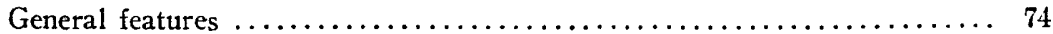

Modes of transportation ................................. 74

Factors that influence transportation and deposition of sediment $\ldots \ldots \ldots 75$

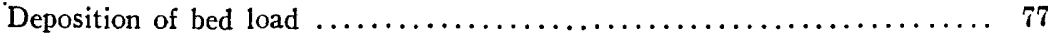

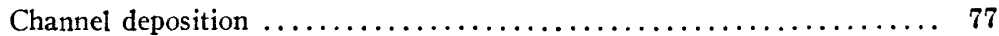

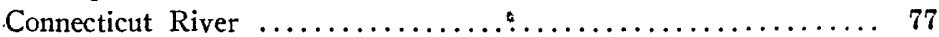

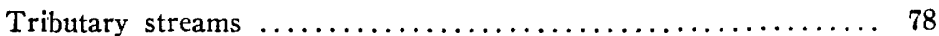

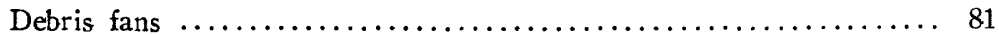

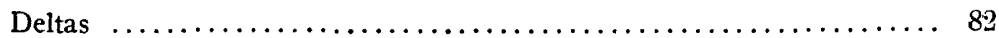

Suspended-load deposits of recent floods $\ldots \ldots \ldots \ldots \ldots \ldots \ldots \ldots \ldots \ldots$. 84

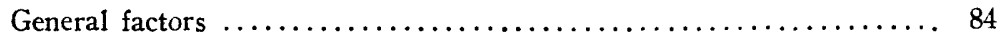

Distribution, appearance, and preservation $\ldots \ldots \ldots \ldots \ldots \ldots \ldots \ldots .65$

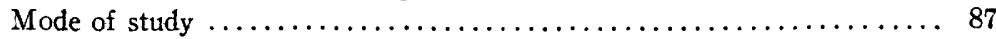

Field investigations $\ldots \ldots \ldots \ldots \ldots \ldots \ldots \ldots \ldots \ldots \ldots \ldots, 87$

Mechanical analyses $\ldots \ldots \ldots \ldots \ldots \ldots \ldots \ldots \ldots \ldots \ldots \ldots \ldots \ldots$

Materials in the depesits $\ldots \ldots \ldots \ldots \ldots \ldots \ldots \ldots \ldots \ldots \ldots \ldots . \ldots \ldots$

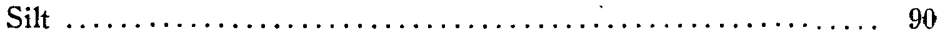

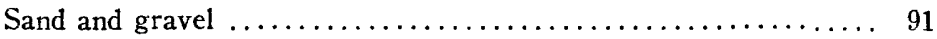

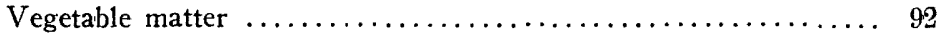

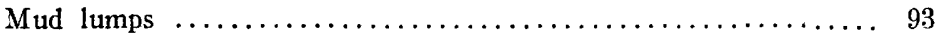

Other materials $\ldots \ldots \ldots \ldots \ldots \ldots \ldots \ldots \ldots \ldots \ldots \ldots \ldots \ldots \ldots$

General features of the deposits $\ldots \ldots \ldots \ldots \ldots \ldots \ldots \ldots \ldots \ldots \ldots \ldots \ldots$

Thickness .................................... 94

Mechanical composition ............................ 96

Sedimentary structures $\ldots \ldots \ldots \ldots \ldots \ldots \ldots \ldots \ldots \ldots \ldots \ldots . \ldots 7$

Criteria for recognition and discrimination of flood deposits $\ldots \ldots \ldots \ldots 98$

Age-environmental relations $\ldots \ldots \ldots \ldots \ldots \ldots \ldots \ldots \ldots \ldots \ldots \ldots \ldots \ldots$

Effects of environment on textures of deposits $\ldots \ldots \ldots \ldots \ldots \ldots \ldots \ldots 110$

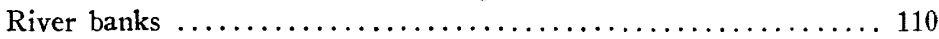

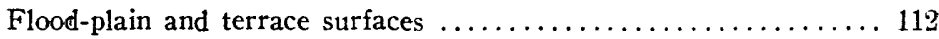

Embayments in small tributary ravines $\ldots \ldots \ldots \ldots \ldots \ldots \ldots \ldots 112$

Flood-plain surfaces at mouths of large tributaries $\ldots \ldots \ldots \ldots \ldots 113$

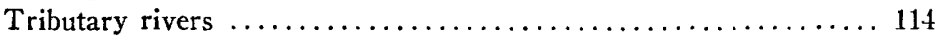

Summary of suspended-load deposits $\ldots \ldots \ldots \ldots \ldots \ldots \ldots \ldots \ldots \ldots \ldots \ldots$

Materials associated with the flood deposits $\ldots \ldots \ldots \ldots \ldots \ldots \ldots \ldots \ldots \ldots \ldots \ldots$

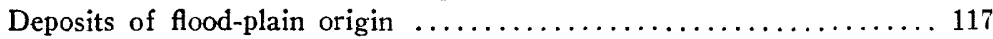

Deposits of floods of probable occurrence during past 150 years .... 121

Deposits of unknown or doubtful origin $\ldots \ldots \ldots \ldots \ldots \ldots \ldots \ldots \ldots \ldots \ldots$

Relation of this study to the study of earlier flood deposits $\ldots \ldots \ldots \ldots \ldots 125$

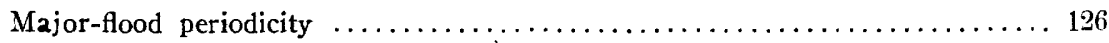

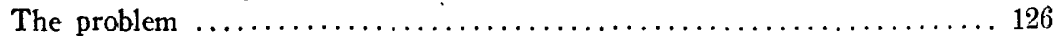

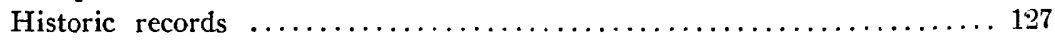

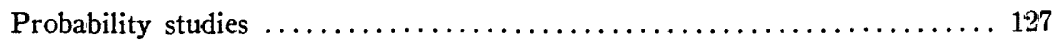

Evidence of modern-flood deposits beneath the flood deposits of $1936 \ldots \ldots 128$

Evidence of deposits at levels higher than the flood crest of 1936 ...... 129 
Major-flood periodicity-Continued. Page

Evidence from low river-terrace sections $\ldots \ldots \ldots \ldots \ldots \ldots \ldots \ldots \ldots \ldots . \ldots 129$

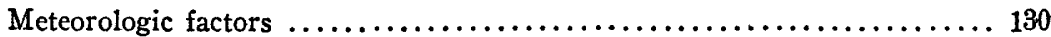

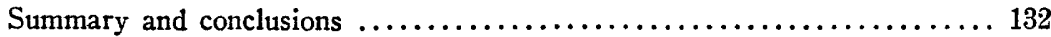

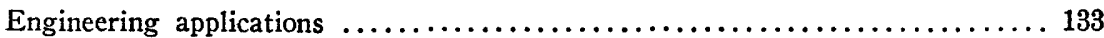

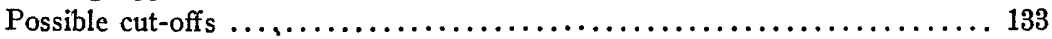

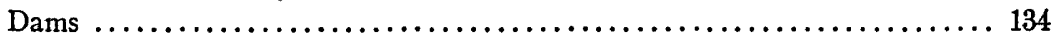

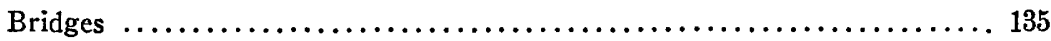

Mechanical analyses of flood sediments and associated materials $\ldots \ldots \ldots \ldots \ldots 137$

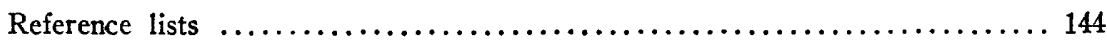

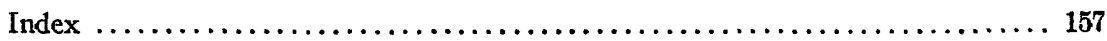

\section{ILLUSTRATIONS}

Plate 1. Generalized physiographic map of the Massachusetts part of the

Connecticut Valley and adjacent areas ............... In pocket

2. Generalized geologic map of the Massachusetts part of the Connecticut Valley and adjacent areas .................. In pocket

3. Quadrangle index map of central-western Massachusetts showing physiographic division of the principal flood-plain and river-

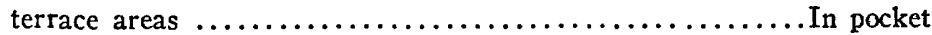

4. $A, B$, Northampton region of the Connecticut Valley; $C$, Northfield area, 2 days after passing of flood crest in March

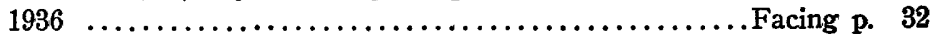

5. Axial part of the Connecticut Valley north of Mount Warner and southwest of Mount Toby ..................... In pocket

6. $A, B$, East bank of Connecticut River 1 mile south of

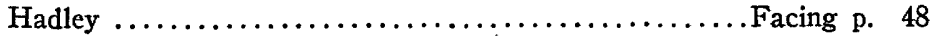

7. Profiles of the Connecticut River and other important rivers in the United States.$\ldots \ldots \ldots \ldots \ldots \ldots \ldots \ldots \ldots \ldots \ldots \ldots$. In pocket

8. Block diagrams of an idealized area along the Connecticut River, showing relations of certain river stages to land forms ...... In pocket

9. Discharge curves for the Connecticut River and important tributaries in Massachusetts during the period March 8 to April 10,

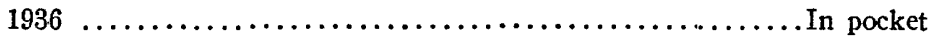

10. Connecticut Valley areas inundated by floodwaters in March 1936, compared with total river-terrace and flood-plain areas ..... In pocket

11. $A$, Connecticut and Fort Rivers in Hadley area at normal winter low-water stage; $B$, Generalized map of Quaternary land forms in the Hadley area ........................... Facing p. 64

12. Connecticut and Fort Rivers, floodwater inundation in March 1936 .............................................. 72

13. $A, B$, Hadley area during flood of March $1936 \ldots \ldots . .$. Facing p. 80

14. $A, B$, River conditions near Mount Tom Junction.........Facing p. 81

15. Gage-height curves for the Connecticut River at Montague, Mass., March 8 to April 10, 1936, and September 18 to October $11,1938 \ldots \ldots \ldots \ldots \ldots \ldots \ldots \ldots \ldots \ldots \ldots \ldots \ldots$. In pocket

16. Recent flood-crest profiles of the Connecticut River in Massachu-

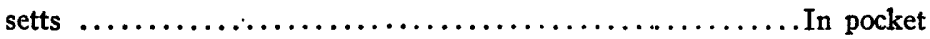


Plate 17. $A, B$, Recent gully and fan development west of Montague Facing p. 88

18. Bed-load characteristics of certain Connecticut Valley streams In pocket

19. $A, B$, Flood sediments near Connecticut River, March 1936 ............................................... 96

20. $A, B$, Typical flood deposits of Connecticut River.........Facing p. 104

21. General characteristics of recent flood deposits in the Connecticut

River drainage basin, Massachusetts ................. In pocket

22. Typical structural criteria for discrimination and interpretation of flood deposits $\ldots \ldots \ldots \ldots \ldots \ldots \ldots \ldots \ldots \ldots \ldots \ldots \ldots \ldots \ldots \ldots$ In pocket

23. $A, B, C, D$, Flood deposits in banks of small stream east of East Deerfield .............................. Facing p. 120

24. Relations and characteristics of recent flood sediments in lower part of small stream east of East Deorfield .............. In pocket

25. General characteristics of recent flood sediments of the Connecticut River in various depositional environments ............ In pocket

26. Graphs of mechanical analyses of Connecticut Valley flood sediments and associated deposits ....................... In pocket

27. General characteristics of certain pre-1936 deposits in the Connecticut Valley ................................. In pocket

28. Distribution throughout the year of damaging floods on the lower Connecticut River ............................ In pocket

29. Comparison of flood-crest heights at Hartford, Conn. ..........In pocket

30. General summary of certain meteorologic conditions over the northern and central parts of the Connecticut River drainage basin for the period 1888 to $1939 \ldots \ldots \ldots \ldots \ldots \ldots \ldots \ldots$. In pocket

31. $A, B$, Davitt Memorial Bridge in Chicopee........... Facing p. 136

32. $A, B$, Flood conditions in lower Avery Brook, west of East Charlemont ............................. Facing p. 144

33. $A, B$, Bridge structures subject to flood damage........Facing p. 145

Figure 1. Drainage basin of the Connecticut River $\ldots \ldots \ldots \ldots \ldots \ldots \ldots \ldots$

2. Suggested general structure and mode of development of Connecticut River flood plains during postglacial time ........... 38

3. Bed-load characteristics of Sawmill River south of Montague,

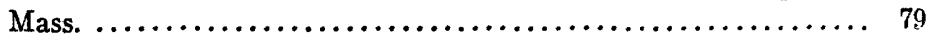

4. Ideal sections of Connecticut River flood deposits ........... 104

\section{TABLES}

TABLE 1. Climatic features of the Connecticut River drainage basin ...... Page 10

2. Important cities in the Massachusetts part of the Connecticut River drainage basin ......................... 12

3. Geologic time classification of United States Geological Survey..... 18

4. Connecticut River terrace and flood-plain levels in Massachusetts ... 34

5. Section of sediments in low terrace (III), north edge of swirlpit area, 1 mile north of Hatfield $\ldots \ldots \ldots \ldots \ldots \ldots \ldots \ldots \ldots . \ldots \ldots$

6. Section of sediments in intermediate terrace (II), east bank of Connecticut River, 1.6 miles northwest of Montague ......... 47

7. Comparison of certain major rivers of the United States ....... 52 
TABLE 8. Relative extent of floodwater inundation in the Massachusetts part of the Connecticut Valley, March 1936

9. Comparative crest stages of great floods at selected points in the Connecticut River drainage basin .................... 6.5

10. Sections showing typical flood deposits $\ldots \ldots \ldots \ldots \ldots \ldots \ldots \ldots . \ldots 8$

11. Partial chemical analyses of flood sediments and associated materials from the Connecticut Valley, Mass. ................ 91

12. Section of flood deposits on bank of Fourmile Brook between River Road and Central Vermont Railroad, 0.2 mile northwest of Northfield Farms

13. Comparative thicknesses of recent flood deposits of the Connecticut River ................................... 95

14. Sections showing typical flood deposits $\ldots \ldots \ldots \ldots \ldots \ldots \ldots \ldots \ldots$

15. Relative duration of successive river conditions during extraordinary flood periods of March 1936 and September 1938 ...... 103

16. Sections showing typical flood deposits in small tributary stream northwest of fish hatchery $\ldots \ldots \ldots \ldots \ldots \ldots \ldots \ldots \ldots \ldots \ldots \ldots$

17. Sections showing flood deposits on lee side of river bend 0.7 mile north of North Hadley .......................... 111

18. Section showing flood deposits on bank of Fort River, 200 feet downstream from Old Mill Pond dam .................... 114

19. Sections showing typical flood deposits from flood-plain areas along Deerfield River ................................ 114

20. Section showing flood deposits at Station Wo2 in Westfield Meadows, near Tekoa Country Club, 1.5 miles west-northwest

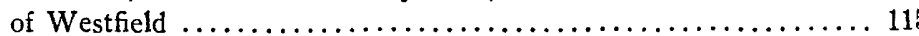

21. Section of sediments in eroded terrace front, east bank of Connecticut River, 1.1 miles south of Hadley ................ 117

22. Position and lithology of members of terrace section adjacent to swirl-pit area, 0.6 mile WNW. of North Hadley ............ 120

23. Sections showing recent flood desposits in relation to underlying deposits of unknown or doubtful origin 


\title{
GEOLOGIC FEATURES OF THE CONNECTICUT VALLEY, MASSACHUSETTS AS RELATED TO RECENT FLOODS
}

\author{
By Richard H. Jahns
}

\begin{abstract}
This report gives the results of a geologic study of certain features that bear upon the recent flood behavior of rivers flowing in the Massachusetts part of the Connecticut Valley. It is in part an outline of the physiographic history of the Connecticut River, a history that is treated in progressively greater detail as it concerns events occurring from Mesozoic time to the present, and in part a discussion of erosional and depositional processes associated with the extraordinary floods of March 1936 and September 1938.
\end{abstract}

The Connecticut River flows southward through Massachusetts in a broad lowland area of more than 400 square miles and is joined in this area by four large tributaries, the Deerfield and Westfield Rivers from the west and the Millers and Chicopee Rivers from the east. The lowland area, or Connecticut Valley province, is flanked on the west by the Berkshire Hills, a deeply incised uplifted plateau, and on the east by the central upland, or Worcester County plateau, a lower upland marked by rolling topography. Most of the broad, relatively flat valley floor is underlain by Triassic sedimentary rocks. Rising above it, however, are the prominent Holyoke-Mount Tom and Deerfield Ranges, which consist in large part of dark-colored igneous rocks, also of Triassic age.

There is evidence of several cycles of erosion in central western Massachusetts, the last two of which are of Tertiary age and appear to have reached mature and very youthful stages of topographic development, respectively. Immediately prior to the glacial epoch, therefore, the Connecticut River flowed in a fairly narrow, deep gorge, which it had incised in the rather flat bottom of the valley that it had formed at an earlier stage. A Pleistocene crustal subsidence probably of several hundred feet, for which there has been only partial compensation in postglacial time, was responsible for the present position of much of this gorge below sea level. That an estuary does not now occupy the gorge is due to a filling by glacial debris, notably by sediments deposited in late glacial lakes. Following disappearance of the last ice sheet and draining of the associated lakes, the Connecticut River resumed existence and began a new chapter in its history.

In those areas where the river regained its preglacial course, it now flows on sediments considerably above the rock floor of the old gorge. Where the gorge was narrow and deep, the upper parts of its walls have confined the postglacial river within rather narrow limits, as in the northern part of the state. Where it was sufficiently wide to be filled by glacial sediments over large areas, the postglacial river has meandered broadly, as in the area north of the Holyoke-Mount Tom Range. In two areas in Massachusetts and in one immediately south in Connecticut, however, the river was forced from its preglacial gorge, and its new channel has been superimposed on bedrock, with development of rapids and falls. Each of these postglacial rock channels acts as a spillway whose level controls the local base level of 
the river as far upstream as the next spillway. These spillways are not to be confused with other, more spectacular gorges, which are of preglacial origin and in which the present river does not flow on bedrock.

The Recent Connecticut has formed extensive flood plains and terraces through repeated sequences of erosion by lateral corrasion and downward scour, followed by deposition of silt and sand veneers. These features, although irregular in detail, appear to be assignable to five general levels, whose means are approximately 49,37 , 30,18 , and 10 feet above present mean river level. In addition, an 80-foot terrace in the northern part of the valley was left perched in its present position when the Connecticut abandoned its course over a rock barrier near Turners Falls in favor of an adjacent much lower gap. The normal terraces and flood plains slope very gently away from their riverward edges and are bordered on their inner margins by distinct scarps that in many places are the scars of earlier meanders. Most of them appear to have been formed as meander plains, and were subsequently covered with typical flood-plain deposits. The early Recent Connecticut had strong mêandering tendencies, which have become progressively less and less pronounced. Only one meander, the peculiar bend at Hadley, exists today, but several oxbows and one large oxbow lake are preserved.

It is possible to correlate some of the well-defined stages of recent great floods along the river with the inundation of certain flood-plain and terrace levels from place to place. This has been helpful in the interpretation of layers of markedly different texture in the recent flood deposits. The flood of March 1936, which broke all existing discharge and crest-height records along the lower Connecticut, was especially remarkable because it caused temporary resumption of flood-plain activity on many parts of the 30 -foot terrace level, an unprecedented action since settlement of the valley. The hurricane flood of September 1938, which reached crest heights nearly as great, also inundated this terrace, but to a lesser degree.

Erosion by the excessively heavy runoff in both 1936 and 1938 took the form of landslides on steep slopes, local and. small gullying in pastures and along roads, and very severe bank corrasion along large rivers in the upland regions, but was generally confined in those regions to rather small areas. In the Connecticut Valley heavy, destructive river scour on fertile flood plains and terraces occurred at points of extraordinary floodwater concentration. Strong bank erosion was confined to the outer margins of two bends; the stabilizing influence of vegetation was effective at all other places.

Most of the sedimentation associated with the recent floods was in the form of suspended-load deposition of sands and silts to an average depth of $13 / 8$ inches over an inundated area 38 square miles in extent in 1936, and to an average depth of $7 / 8$ inch over a slightly smaller area in 1938. Clay is absent from these deposits. Vegetable material such as leaves, twigs, stalks, and wood chips is intimately mixed with sandy deposits in some places and occurs as distinct partings in others. The sedimentary sequences are commonly layered, and it is possible to correlate thickness and texture of these layers with the height and duration of the various flood stages.

Nearly 200 mechanical analyses show that the deposits of the March 1936 flood are generally coarser than those of the later hurricane flood. Both show best sorting on the outer margins of flood-plain areas and in the ravines of small tributary brooks and are coarsest on the river banks. Systematic textural variations are definitely related to differences in depositional environments, but these variations are not of great magnitude. The flood deposits of large tributary rivers are appreciably coarser than those of corresponding age and position along the Connecticut.

From an evaluation of known historic records, together with evidence furnished by the texture, structure, thickness, and position of the recent flood sediments and materials associated with them, it is concluded that no flood as great as or greater 
than that of March 1936 has visited the Massachusetts portion of the Connecticut Valley since civilization began there, and probably not for several hundred years prior to that time. Although there is no reason to believe that an equally or even more severe flood could not occur at any time in the future, the chances for such an occurrence at any time appear to be small.

Several notes and suggestions concerning engineering applications of this study are included at the end of the report. A rather extensive bibliography on a variety of subjects related to the text of the report is appended.

\section{INTRODUCTION}

\section{PURPOSE AND SCOPE OF INVESTIGATIONS}

The investigation of the recent flood behavior of the lower Connecticut River was undertaken by the Geological Survey at the suggestion of Richard K. Hale, Commissioner of Waterways for the Commonwealth of Massachusetts. It was hoped that this study might lead to a determination of the periodicity of such extraordinary floods as those of March I936 and September 1938, which is an important factor in the designing of bridges, dams, and other structures affected by river discharges of great magnitude, as well as in the formulation of a unified, well-considered plan for flood control. The most promising avenue of approach to the problem appeared to be the spatial and textural relations of the recent flood deposits to associated older materials.

After field work was begun on the problem, however, it became apparent that a thorough knowledge of the postglacial activity of the Connecticut River would be essential to any reasonably complete understanding of these flood deposits and their significance as related to the frequency of great floods. Hence, the investigation was extended to include the older river sediments and those deposits of the glacial sequence that bear directly on the problem. The mutual relations and physiographic characteristics of such Quaternary deposits were examined as thoroughly as time permitted. The reconstructed history of the postglacial Connecticut River, as well as those phases of the earlier physiographic history of the general region that are included in this report are largely the outgrowth of these expanded studies.

\section{ACKNOWLEDGMENTS}

The investigations were carried on in cooperation with the Commonwealth of Massachusetts. They were begun under the direction of $\mathrm{G}$. R. Mansfield, who, during the 4 days he spent with the writer in the field, drew on his previous experience with flood-deposit studies in the Ohio Valley in making many valuable suggestions. L. W. Currier, who has studied general flood conditions throughout western New England, contributed important information and suggestions during many discussions in the field and in the office. Professor Robert Balk, of Mount Holyoke College, furnished much information concerning the geology 
of the valley and the central upland areas. H. B. Kinnison, district engineer in the Water Resources Branch of the Geological Survey, made available unpublished gage-height and discharge data for the hurricane flood of 1938, as well as topographic maps on which had been outlined the position of maximum extent of the 1936 flood waters. The writer is also indebted to members of the Water Resources Branch for making mechanical analyses of many of the sediment samples collected and to members of both the Water Resources and Geological Branches for critical examination of the manuscript.

Acknowledgments are due to James Daly and Arthur Regan, of the Holyoke Daily Transcript-Telegram, for furnishing many photographs of flood scenes in the valley; to Col. J. S. Bragdon, district engineer, United States Army Engineers Office in Providence, R. I., for the use of aerial photographs taken in March 1936; to G. C. Whitney, of the Greenfield Recorder-Gazette, for supplying a vivid description, as well as photographs of flood scenes in the Turners Falls-Montague area; and to W. F. Cummings, chief engineer of the Boston and Maine Railroad, G. A. Kirley, chief engineer of the Boston and Albany Railroad, R. D. Garner, chief engineer of the Central Vermont Railway, and G. E. Harkness, bridge engineer of the Massachusetts Department of Public Works, for detailed information concerning flood damage to bridges in the Massachusetts portion of the Connecticut River watershed during 1936 and 1938 .

\section{FIELD WORK}

Eight weeks were spent in the field during June, July, and September I939 and 2 additional weeks in April 1940. During those periods the glacial terraces along the axial portion of the Connecticut Valley were examined in many places and the river terraces and flood plains were examined and mapped in reconnaissance. Detailed sections of the flood plains and river terraces were measured at 14 places. Where the Connecticut has been diverted from its preglacial channel a study of the critical areas was made wherever possible. Investigations of flood damage were made along the Connecticut River, as well as along the middle and lower reaches of the Deerfield, Westfield, Millers, Sawmill, and Chicopee Rivers.

Inspection of recent flood sediments in the valley was made at 6 I I places, chosen to give the most uniform distribution consistent with the locations of reasonably undisturbed deposits. Detailed sections were measured and interpreted at 204 of these localities, and 262 representative suspended-load samples were collected. These included deposits of the floods of November 1927, March 1936, and September 1938, as well as deposits of the spring high water period of I939. In addition, samples were taken from flood-plain and terrace sections, from deposits of floods earlier than 1927, and from deposits lying above the level reached by 
the I936 flood waters. Thirty bed-load samples were collected from high-water riffles and bars along 6 rivers, from a small debris fan, and from a coarse deltaic deposit.

\section{LABORATORY WORK}

One hundred ninety-three mechanical analyses were made of suspended-load deposits, including those of recent floods, earlier floods, and those of unknown or doubtful origin. The analytical work was done in the laboratories of the Water Resources Branch of the Geological Survey by M. D. Reeves and J. D. Hem under the direction of C. S. Howard. Sieve analyses of 18 bed-load samples were made by the writer, and partial chemical analyses of 5 miscellaneous samples were made by R. E. Stevens in the chemical laboratories of the Geological Survey. Microscopic examinations of concentrates from some of the mechanical analyses were made by the writer, although available time permitted nothing more than an identification of their mineral and rock constituents.

\section{FORM OF REPORT}

This report is largely an outline of the physiographic history of the Connecticut River from Mesozoic time to the present. The features that indicate the postglacial behavior of the river are treated in greatest detail, and are used as a background for the interpretative discussion of recent flood deposits. Some important sections of the report are followed by summaries. Many of the processes associated with the flood activities of rivers are discussed only briefly, but rather extensive bibliographies covering the most useful references on the subject are included in the appendix. It is hoped that these bibliographic lists will bring up to date the list of references on floods published several years ago by the Geological Survey. ${ }^{1}$

Because the area investigated is large, the large-scale topographic maps that cover it are not included with this report. They are readily available from other sources, however, and should be at hand for a complete understanding of much of the information here given. Plate 3 shows the names and positions of the quadrangles for the areas mentioned in the text. Four small-scale maps of the valley and several large-scale maps of important areas are included.

1 Jarvis, C. S., and others, Floods in the United States, magnitude and frequency: U. S. Geol. Survey Water-Supply Paper 771, pp. 468-487, 1936. 


\section{GENERAL FEATURES OF THE CONNECTICUT VALIEY DRAINAGE BASIN IN MASSACHUSETTS}

\section{LOCATION AND EXTENT}

The drainage basin of the Connecticut River, which has an area of II,320' square miles, is the largest in New 'England. It extends from northern New Hampshire and adjacent portions of Quebec Province southward to Long Island Sound and drains large parts of four states. (See fig. I.) Its marked elongation is demonstrated by its maximum length of approximately 280 miles and its maximum width of but 62 miles. Of the entire basin area 2,7 ro square miles, slightly less than one-fourth, lies in Massachusetts.

The Connecticut River itself is nearly 400 miles long and has a fall of more than $I, 640$ feet. It flows in a southerly direction through central-western Massachusetts, where it is joined by four important tributaries. The Deerfield and Westfield Rivers drain large areas in the Berkshire Hills and join the Connecticut from the west near Turners Falls and Springfield, respectively. The Millers River flows westward from the so-called central upland and empties into the Connecticut a few miles east of Turners Falls. The Chicopee River, fed by the Swift, the Ware, and the Quaboag, flows into the Connecticut at Chicopee, between Holyoke and Springfield. The courses of these four chief tributaries form a symmetrical pattern about a north-south axis. (See fig. r.) Several smaller tributaries that flow directly into the Connecticut are also worthy of mention. From the west, Fall River empties at Turners Falls; Green River, near Greenfield; Mill River, north of Northampton; and Manhan and Mill Rivers, south of Northampton. From the east, Sawmill River enters south of Turners Falls; Mill River, northeast of Northampton; Fort River, east of Northampton; and Bachelor Brook, north of Holyoke.

\section{TOPOGRAPHY}

In a broad way, the Massachusetts part of the Connecticut River drainage basin is divisible into three parts, which trend from north to south. These are the Berkshire Hills on the west, the Connecticut Valley in the center, and the central uplands, or Worcester County plateau on the east.

The Berkshire Hills constitute the southern extension of the Green Mountain chain, commonly termed in this region the Green Mountain Plateau. In its northern part, the broad, gently undulating upland surface attains a general summit altitude of slightly more than 2,000 feet with local peaks rising to more than 2,800 feet. The general crest altitude gradually decreases southward to the Connecticut state line, where it is only I,500 feet. Because of the deep, narrow valleys of the Deerfield and Westfield Rivers and their tributaries, the maximum 


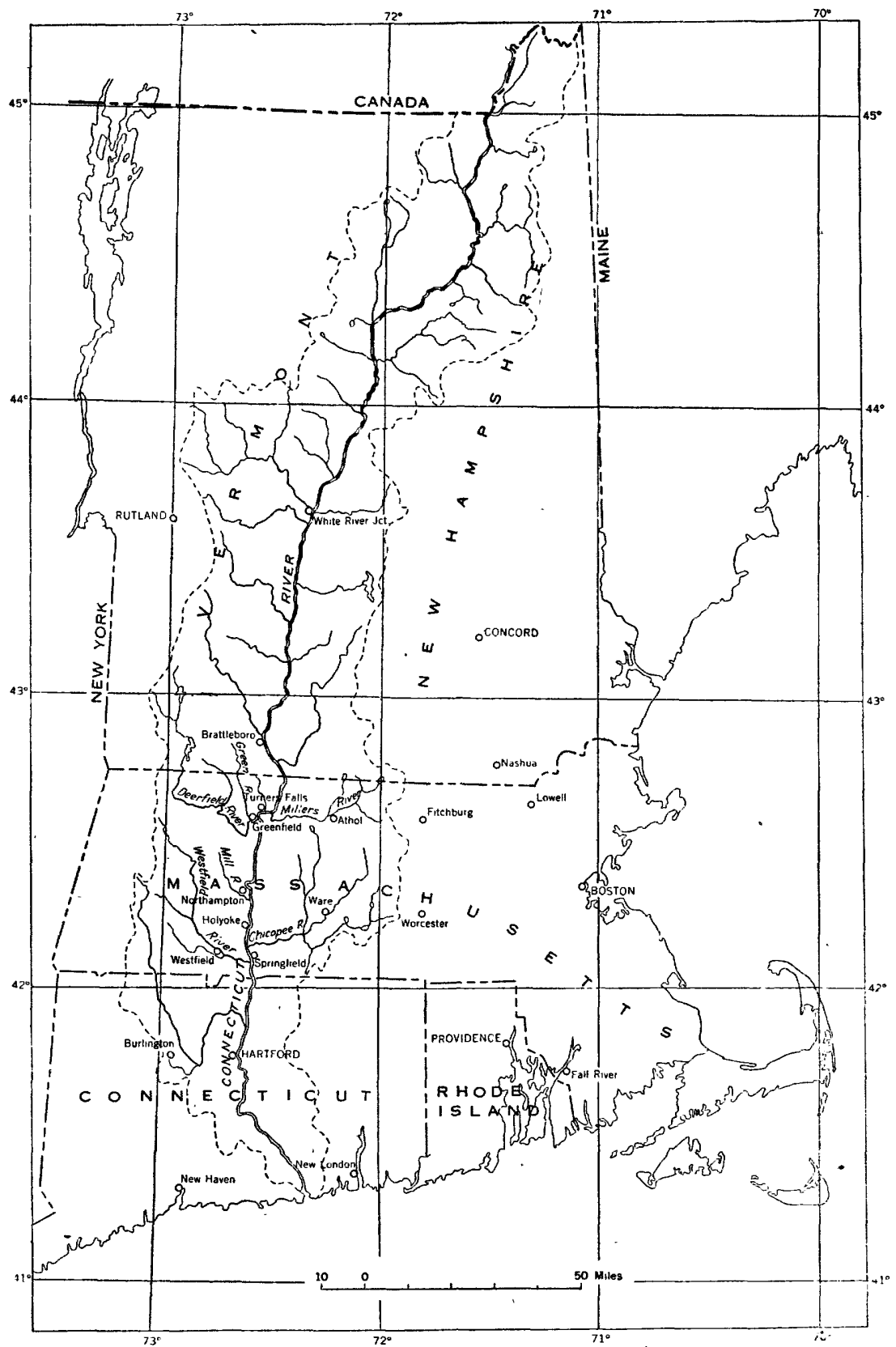

Figure 1.-Drainage basin of the Connecticut River.

total relief, nearly 2,300 feet, is relatively great. Very steep slopes are characteristic of some of the valleys, although the upland surface as a whole slopes gently eastward toward the Connecticut Valley. 
The central upland, or Worcester County plateau, is more broadly rolling, but lies in general at a much lower altitude than the Berkshire Hills. The topography of its easternmost portions is much subdued, so that the drainage divide is poorly marked. It rises to little more than I,O00 feet in most places. Excepting the lower course of the Millers River, the streams are not deeply incised, but flow in relatively broad, open valleys.

The Connecticut Valley, commonly called the central or Triassic lowland, is sharply delineated from the higher areas to east and west. The shape of this great lowland area is roughly that of a tall, narrow isosceles triangle, with its base at the Connecticut state line and its vertex at the Vermont state line. (See pl. I.) The valley floor, which occupies an area of 353 square miles, lies at altitudes between 100 and 400 feet. Its widest parts are flat to gently rolling plains, here called the Westfield, Springfield-Agawam, and Hadley Plains. (See pl. r.)

In all other parts of the Connecticut Valley, the generally flat topography of its floor is interrupted by prominent hills and ridges. Most impressive of these is the Holyoke-Mount Tom Range, a bold, crescentic ridge that extends westward from Belchertown and curves southward between Holyoke and Westfield. Mount Norwottock and Mount Holyoke, with altitudes of more than I,IOO and 950 feet, respectively, are the highest points of this ridge east of the Connecticut River. Immediately west and south of the river, Mt. Nonotuck ( 822 feet) and Mount Tom ( $\mathrm{I}, 2 \mathrm{O} 2$ feet) mark the crest line of the highest part of the range, which continues southward into Connecticut as a distinct but much lower ridge.

Mount Warner (5I4 feet), an isolated, nearly equidimensional hill, rises sharply from the Hadley Plain a few miles west of Amherst and forms a prominent landmark in an area of otherwise low relief. East of Sunderland the large, rugged mass of Mount Toby rises to an altitude of more than $\mathrm{I}, 260$ feet. This mountain marks the northern limit of extensive plains in the Connecticut Valley. West of the river, opposite Mount Toby, are two very steep-faced hills, North Sugarloaf (79t feet) and South Sugarloaf (652 feet). They mark the southern end of the Deerfield Range, a high, ridgelike mass, which extends northward to Greenfield, thence eastward in an arc to a point opposite Turners Falls.

All other highland areas within the Connecticut Valley are of lesser prominence and of smaller extent, with the exception of an ill-defined group of rolling to rugged hills between Turners Falls and Bernardston. That these are not strictly analogous to the ridges and hills already discussed will be shown in the following section. Small individual hills and knobs, as well as local groups of low ridges are scattered throughout the remaining parts of the valley. They are particularly common southeast 
of Springfield, south of the Holyoke Range, southwest of Easthampton, Northampton, and Northfield, and in the vicinity of Amherst.

Irregularly bounded areas of flat lowland meadows flank the Connecticut River and the lower reaches of the Deerfield; Westfield, and Chicopee Rivers. They lie below the general level of the valley floor, and the maximum elevation of those along the Connecticut exceeds 50 feet above normal river stage only in the Northfield area, where an anomalous 80 -foot terrace is very prominent. These meadows are the river-terrace and flood-plain areas of the Connecticut Valley; they represent the portion of the valley that has been subject to flood-water inundation in Recent geologic times.

\section{sOILs}

Most of central-western Massachusetts falls within the region where the brown forest soils of the North Atlantic states are developed. ${ }^{2}$ In the higher areas of the Berkshire Hills, however, podsolic soils, with their surface accumulations of raw humus, are developed to an appreciable degree. In general, the soils are weathered to a depth of 2 or 3 feet, and are only slightly leached. Individual types are dominantly stony, sandy, and silty loams and subordinately loamy sands and fine sands. ${ }^{3}$

The highland soils, derived mainly from till, are fertile but stony. The valley soils are generally free of stones. Those resting on glacial sands and sandy silts are relatively poor in plant food and because of their more porous structure are leached to a greater degree than the highland soils. The other important type, derived from river flood-plain silts, has undergone little or no leaching and is the most fertile soil in the region. The last named feature is largely responsible for the intensive farming activity closely adjacent to principal rivers.

\section{CLIMATE}

The climate of the Connecticut River drainage basin is humid and is characterized by long, cold winters, short but comparatively warm sum'mers, and frequent weather changes. Precipitation is so uniformly distributed throughout the year that no distinction between wet and dry seasons can be made for any area. There are important distinctions, however, between the climate of Vermont, New Hampshire, and the Berkshire Hills in Massachusetts and that of the lower portions of the drainage basin, notably the Connecticut Valley itself. (See table I). The central uplands area in Massachusetts has climatic conditions intermediate between these two.

Precipitation in the northern states averages about 40 inches per year,

a Latimer, W: J., Smith, L. R., and Howlett, Carey, Soil Survey of Franklin County, Mass.: U. S. Dept. Agr. Bur. Chemistry and Soils, ser. 1929, no. 9, pp. 14-18, 33-43, 1929. Latimer, W. J., and Smith, L. R., Soil Survey of Hampden and Hampshire County, Mass.: U. S. Dept. Agriculture, Bur. Chemistry and Soils, ser. 1928, no. 25, pp. 18-20, 40-57, 1928.

' Latimer, W. J., and Smith, L. R., op. cit., pp. 20-40, 1928. $689520-47-2$ 
of which about one-quarter is snow. Although the annual precipitation is somewhat greater in the valley areas to the south, a much smaller proportion occurs as snow there. The winter season is longer in Vermont and New Hampshire, the spring and fall seasons correspondingly shorter. The Connecticut Valley in Massachusetts, with its relatively warm spring and fall seasons, is characterized by a frost-free, or growing, period surprisingly long for so northerly a latitude.

TABLE 1.-Climatic features of the Connecticut River drainage basin ${ }^{1}$

\begin{tabular}{|c|c|c|}
\hline & $\begin{array}{l}\text { Vermont, New Hampshire } \\
\text { and Berkshire Hills } \\
\text { area in Massachusetts }\end{array}$ & $\begin{array}{l}\text { State of Connecticut } \\
\text { and Connecticut Valley } \\
\text { area in Massachusetts }\end{array}$ \\
\hline \multicolumn{3}{|l|}{ Mean temperature:2 } \\
\hline Winter $\ldots \ldots \ldots \ldots \ldots \ldots \ldots \ldots{ }^{\circ} \mathbf{F}$. & 19 & 28 \\
\hline 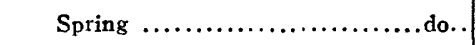 & 41 & 44 \\
\hline 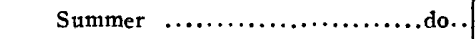 & 65 & 68 \\
\hline Fall ............................. & 47 & 52 \\
\hline 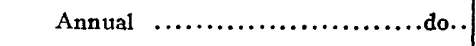 & 43 & 48 \\
\hline \multicolumn{3}{|l|}{ Mean precipitation:2 } \\
\hline Winter.$\ldots \ldots \ldots \ldots \ldots \ldots \ldots$.............. & 8.9 & 11.0 \\
\hline Spring $\ldots \ldots \ldots \ldots \ldots \ldots \ldots \ldots \ldots$ do.... & 9.5 & 11.1 \\
\hline 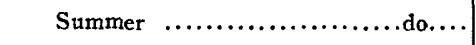 & 10.9 & 11.1 \\
\hline 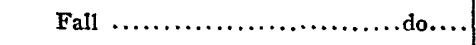 & 10.4 & 11.0 \\
\hline 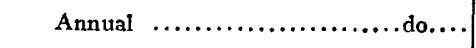 & 39.7 & 44.2 \\
\hline Mean annual snowfall ${ }^{3} . \ldots \ldots \ldots$...inches.. & 80 & 45 \\
\hline Average length of spring season .weeks.. & 5 & 8 \\
\hline Average, length of fall season $\ldots$. .do.... & 6 & 8 \\
\hline $\begin{array}{l}\text { Days per year. with temperature } 32^{\circ} \mathrm{F} \\
\text { or below. }{ }^{3}\end{array}$ & 180 & 26 \\
\hline $\begin{array}{l}\text { Days per year with temperature } 0^{\circ} \mathrm{F} \text {. } \\
\text { or below. }{ }^{3}\end{array}$ & 12 & 3 \\
\hline 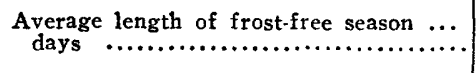 & 120 & 185 \\
\hline
\end{tabular}

1 All factors in the first column are used in accordance with definitions and data that appear in the climatic summary of the United State's, sections 84-85, issued by the United States Weather Bureau.

2 Based on records complete from 1888 through 1939.

Based on long-time records, but approximate because of difficulties in averaging data.

\section{NATIVE VEGETATION}

Those parts of the Connecticut River Basin that are not actively cultivated or used as pasture land are heavily wooded. The extensive development and maintainance of this forest cover has been of particular significance in retarding erosional processes occasioned by surface runoff, particularly in the upland areas. The nature of this vegetation in the 
Massachusetts portion of the basin is admirably summarized by Latimer and Smith, ${ }^{4}$ who make the following statement:

The area lies in a region where the forest flora of the south, typified by oak, chestnut, and yellow popular (tuliptree), merges with the spruce, canoe (white) birch, and hard maple forest of the north. The forest on the western highland consists mainly of spruce, beech, yellow birch, white birch, and rock maple; on the eastern highland, mainly of oak, chestnut, white pine, white birch, and gray birch; and in the valley the dominant growth is gray birch, white birch, pitch pine, oak, and cedar.

The natural vegetation of New Hampshire and Vermont is similar, except that the southern flora disappears northward and the coniferous types become increasingly numerous.

\section{AGRICULTURE}

Since the period of earliest settlement, New England has developed as a region of small farms. The stage of greatest agricultural expansion began early in the nineteenth century and reached its peak in 1880 , when farm acreage was at its maximum. Since that time, in response to changing market conditions, the amount of land under cultivation has decreased considerably. In the Massachusetts part of the Connecticut River Basin, this trend has resulted in gradual abandonment of upland farms in favor of the more fertile and advantageously situated lowland areas. The Connecticut Valley is the most intensively developed farming area in the state. Because of their position the most valuable crop lands are exposed to serious damage during floods, either by river scour or by heavy deposition of sand.

\section{DISTRIBUTION OF POPULATION}

The total population of the Connecticut River drainage basin, according to the I940 census, is approximately $\mathrm{I}, 200,000$, of which four-fifths is contained in the relatively small parts of the basin in Connecticut and Massachusetts. A four-to-one ratio also characterizes the distribution of people in the valley and highland divisions of the area in Massachusetts. The southern end of the valley in this area contains most of the important metropolitan and industrial districts, the final step in the concentration of population.

The large cities in the basin lie along major streams, most of which serve as sources of power and water for industrial use. The following table lists these important cities and shows the river or rivers along which each is located. Most of the smaller cities and towns also lie adjacent to principal drainage arteries.

- Latimer, W. J., and Smith, L. R., op. cit., pp. 2-3, 1928. 
TABLE 2.-Important cities in the Massachnsetts part of the Connecticut River drainage basin

[1940 census figures]

\begin{tabular}{|c|c|c|}
\hline City & Population & Rivers \\
\hline Springfield $\ldots \ldots \ldots \ldots \ldots \ldots$ & 149,554 & Connecticut. \\
\hline Holyoke .. & 53,750 & Do. \\
\hline Chicopee ....... & 41,664 & Connecticut and Chicopee. \\
\hline Northampton .. & 24,794 & Mill. \\
\hline Westfield & 18,793 & Westfield. \\
\hline Gardner .. & 20,206 & $\begin{array}{l}\text { Otter (tributary to Millers } \\
\text { River). }\end{array}$ \\
\hline West Springfield & 17,135 & Connecticut and Westfield. \\
\hline Greenfield & 15,672 & Green. \\
\hline Athol $\ldots$ & 11,180 & Millers. \\
\hline Easthampton & 10,316 & Manhan. \\
\hline Palmer & 9,149 & Quaboag. \\
\hline Ludlow .... & 8,181 & Chicopee. \\
\hline Montague City............. & 7,582 & Connecticut. \\
\hline Ware. & $7,5.57$ & Ware. \\
\hline
\end{tabular}

The Massachusetts part of the drainage basin supports a population of approximately 520,000. Of this, slightly more than a fifth may be classed as rural. Most of this rural population lives in districts suburban to the large cities or is engaged in farming enterprises carried on in valley bottoms immediately adjacent to the Connecticut River and to its larger tributaries. As a result of these concentrations, it becomes evident that a very large percentage of the population, both urban and rural, is directly affected by the behavior of the principal streams. In other words, any serious flood may be expected to create correspondingly serious problems for inhabitants in numbers out of all proportion to the relative extent of inundated areas.

\section{ROUTES OF TRAVEL}

The pattern of travel routes in the basin is closely controlled by topography. The Connecticut Valley, particularly the southern part, serves ideally as a wide avenue for north-south traffic, whereas the Berkshire Hills and the north-central upland region form effective barriers to direct or closely spaced east-west routes. The main east-west line of the Boston and Maine Railroad, for example, must follow the 
windings of the Deerfield and Millers Rivers; that of the Boston and Albany Railroad makes similar use of the Westfield and Quaboag Rivers. The valley, however, is served wholly or in part by north-south lines of the Boston and Maine, Central Vermont, and New York, New Haven, and Hartford Railroads.

The trunk highways, although not subject to the restrictive conditions that affect the railroads, nevertheless show much the same areal pattern. A large network of valley roads gives way to a few through routes in the flanking highland areas. The necessary confinement of transportation routes to the narrow river gorges of these highlands exposes them to flood damage which under certain conditions may become very serious.

Commercial navigation is restricted to that part of the Connecticut River south of Hartford, Conn., although the river is potentially navigable as far upstream as Holyoke. Water traffic therefore plays a negligible part in the Massachusetts area, principally because of dams and bedrock narrows at Holyoke and Turners Falls, as well as the shallowness of the river in intervening areas during the summer and early in the fall.

\section{GENERAL GEOLOGY}

\section{BEDROCK DISTRIBUTION}

\section{HIGHLAND AREAS}

The Berkshire Hills are composed chiefly of highly contorted metamorphic rocks, intruded over large areas by granitic and other crystalline igneous types. The metamorphic rocks consist of more than 20,000 feet of quartz-mica schists and amphibolites, with a thick section of paragneisses at the base. Several pronounced unconformities are present, but many important stratigraphic relations are obscured by faulting and intense folding. Most of these rocks are probably of Paleozoic age, although the basal units may be pre-Cambrian. Certain beds near the top of the section have yielded fossils of Devonian age in the vicinity of Bernardston, but no comparable evidence of age has been obtained from lower beds. The igneous types were probably erupted in Carboniferous time. (See geological time chart, table 3.) Partly because of their metamorphic and igneous character the rocks of the Berkshire Hills are relatively resistant to erosion, hence they have tended to maintain the area as a highland with respect to the Connecticut Valley.

The rocks of the central uplands are dominantly igneous with subordinate elongated masses of Paleozoic(?) metamorphic types. All are presumably of Paleozoic, and possibly of late Paleozoic age. In the vicinity of the drainage divide, at the eastern edge of the area, the uplands are underlain by Carboniferous(?) mica schist. Although relatively re- 
sistant to erosion, the dominant igneous rocks tend to form hills with slopes in general less steep than those in the Berkshire Hills. Additional data pertaining to these two areas are available in the references listed in the bibliography at the end of the report.

\section{CONNECTICUT VALLEY}

The broad lowlands of the Connecticut Valley are underlain almost entirely by Triassic sedimentary rocks. The distribution of these rocks nearly coincides with that of the valley area, as is evident from a comparison of plates $\mathrm{I}$ and 2. Sheets of dark-colored, basic igneous rocks, chiefly volcanic, occur at several places. These igneous rocks are resistant to erosion and form some of the most conspicuous ridges that rise from the valley floor, notably the Holyoke-Mount Tom and the Deerfield Ranges. (See pls. I and 2.) Both Mount Toby and the two Sugarloafs, on the other hand, are composed of very coarse arkosic sandstone and conglomerate. Mt. Warner and the hills south of Bernardston, the only other important high points in the valley, consist of pre-Triassic rocks, and so represent highland masses detached from the central uplands and the Berkshire Hills, respectively. The Triassic rocks merit a more detailed description than do those of the highland areas because they exercised a strong topographic control over land forms in the valley.

The so-called southern basin, or that part of the Triassic area south of Hadley and Northampton, contains a thick series of conglomerate, arkosic sandstone, and shale. The shales occupy central positions, and are flanked to east and west by the coarser sandstones and conglomerates. Two basaltic lava sheets and a zone of tuffaceous material in the vicinity of Mount Holyoke represent Triassic igneous activity in the area. The smaller, northern basin contains a much thinner sedimentary section and but one lava sheet. Conglomerates, very coarse and taluslike at Mount Toby, and arkosic sandstones predominate. The correlation between the two basins is given by Bain ${ }^{5}$ as follows:

\section{Southern Basin}

Chicopee shale, Longmeadow sandstone

Third sandstone.

Granby tuff, second lava sheet.

Second sandstone.

Holyoke [lava] sheet.

First sandstone and conglomerate.

\section{Northern Basin}

Lake beds, Mount Toby conglomerate and sandstone.

Sandstone and conglomerate.

Conglomerate and sandstone.

Deerfield [lava] sheet.

Sugarloaf arkose.

sain, G. W., The northern area of Connecticut Valley Triassic: Am. Jour. Sci., 5th ser., vol. 23, p. 65,1932 . 
In view of their continental origin, it is scarcely surprising that the sedimentary rocks vary greatly in character, both horizontally and vertically, over relatively short distances. Emerson ${ }^{6}$ has demonstrated that at many places totally dissimilar beds were deposited contemporaneously; he states that the Deerfield lava sheet flowed over the muddy bottom of the basin and rests in sequence on the Mount Toby conglomerate, the Longmeadow sandstone, the Sugarloaf arkose, and then again on the Mount Toby conglomerate.

Because the Triassic beds are younger, they are much less deformed than the rocks of the highlands. Their general low to moderate westward and southeastward dips (pl. 2) appear to be a result of a broad postTriassic tilt. Many normal faults cut and offset the basalt ridges; one of these faults may be responsible for the present position of the Deerfield River near its junction with the Connecticut. Much of the eastern edge of the northern basin is defined by a fault, on which at least some of the movement is post-Triassic. Both sides of the southern basin may be similarly defined. Opinions differ concerning the exact locations and continuity of some of these faults, hence they are not included in the geologic sketch map (pl. 2), and the boundaries of the Triassic belt are marked by a dashed line. There is an even greater divergence of opinion concerning the relative amount of post-Triassic movement on the western border faults. It may be stated, however, that varying amounts of postTriassic movement along most of the pre-Triassic border faults has resulted in the maintenance of a grabenlike structure through much of the Connecticut Valley.

\section{SURFICIAL DEPOSITS}

\section{HIGHLAND AREAS}

The blanketing of New England by ice sheets during the Pleistocene epoch has long been an accepted chapter in the later geologic history of the region. Striated, grooved, and polished ledges and erratic boulders attest to the erosive and transporting powers of the ice, but chief among the results of its activity is the mantle of glacial drift that covers most of the area. In central and western Massachusetts, this drift is nearly everywhere the surficial cover; it is absent only from those most-exposed areas where the ice rested directly on bare-rock ledges. Locally, of course, it is covered by later alluvial deposits.

Although it contains stratified deposits of coarse sand and gravel, the drift throughout the Berkshire Hills and central uplands is most commonly a coarse, incoherent, heterogeneous' and unstratified boulder-sand mixture, best described as stony till. This material is distributed as a thin but continuous cover over the more rolling upland areas. Where the larger rivers and streams have cut below the general plateau surface,

- Emerson, B. K., Geology of Massachusetts and Rhode Island: U. S. Geol. Survey .Bull. 597, pp. 96-97, 1917. 
however, the till is correspondingly more variable in thickness. It is virtually absent on the steep rock slopes flanking the upper Deerfield River, for example, whereas in some other places it covers the underlying bedrock to depths of 60 feet or more. Its composition is equally variable. Locally it is represented by accumulations of angular boulders; elsewhere it is a gritty, structureless mass of clay and tiny rock fragments, in which are set boulders of various compositions, sizes, and degrees of angularity. The heterogeneity and stony nature of this upland till enable it to maintain its position on very steep slopes and to resist erosion to a degree greater than is characteristic of most surficial materials.

\section{CONNECTICUT VALLEY}

The surficial deposits of the valley may be classified as follows:

I. Till (ground moraine and drumlins).

2. Glaciofluvial and glaciolacustrine deposits.

3. Postglacial flood-plain and dune deposits.

The valley till, derived in part from the relatively soft Triassic rocks, is sandy and structureless. It differs from the highland till, whose source was predominantly crystalline rocks, in containing fewer and smaller boulders and in having properties that justify the usage of such names as "hardpan" and "boulder clay." The amount of clay actually present, however, is very small. The coarser constituents are set in a dull gray, tough, compact matrix composed of very fine attrite rock particles. This material is most widely exposed within the valley on rounded hills of relatively slight relief, and represents those parts of the ground moraine not covered by later deposits of classes 2 and 3 above. Excellent examples of these till exposures are found southeast of Springfield, south of Westfield, and over a broad area south of the Holyoke Range.

Not all of the valley till is present as ground moraine, however. Rounded hills of elliptical plan, known as drumlins, are very common in the valley and in the lower-lying portions of the highland areas. These drumlins and drumlin groups rise as much as 200 feet above the surrounding plains, and appear to be composed largely, if not entirely, of till. Barnard Hill and Grassy Hill (Northfield quadrangle); Mount Castor, Mount Pollux, and adjacent hills near Amherst; and Round Hill in Northampton are outstanding examples.

The glaciofluvial and glaciolacustrine deposits occupy the greater part of the valley area as groups of broad terraces. The flat tops of the highest group lie about 200 feet above the level of the Connecticut River ; these terraces are composed of gravel and sand, and are located in general near the margins of the valley. Long Plain ( $\mathrm{pl.} \mathrm{5)}$ ) at the south edge of the Mount Toby mass, and Montague Plain, southwest of Millers Falls ( $7^{1 / 2}$-minute Greenfield quadrangle) are members of this 
group. Below the high terraces are very wide and more centrally placed terraces, consisting of värved clay capped by silt and sand, which form large areas of low relief, such as the Hadley Plain. (See pls. I and 5.) A more detailed discussion of the character and genesis of the terrace deposits appears on pages 34 to $5 \mathrm{I}$.

The flood-plain deposits occupy well-defined areas over the lowest parts of the valley, and lie in positions flanking major streams. The levels of such deposits vary from 6 to 80 feet above that of the adjacent river, and their materials are chiefly fine sand and silt. The floodplain sediments are geologically the most recent in the entire region, and the recent flood silts are the youngest members of this group.

\section{PHYSIOGRAPHIC DEVELOPMENT OF THE CONNECTICUT VALLEY IN MASSACHUSETTS}

\section{PRE-PLEISTOCENE HISTORY}

That part of pre-Pleistocene history which bears directly upon the physiography of the Connecticut Valley began with the start of the Mesozoic era. (See table 3.) The preexisting rocks, many of which had been subjected to severe crustal disturbances in past geologic ages, were extenseively folded, faulted, recrystallized, and invaded by igneous material during the tectonic activity that marked the close of the Paleozoic era; the faulting that was a part of this activity outlined the depression now occupied by the Connecticut Valley, which in general sank as a unit with respect to the flanking crustal masses. During Triassic time vast amounts of debris were deposited in the sinking fault basin, and igneous material was injected into and extruded upon these sediments. New crustal movements followed deposition. The basin-border faults probably became active again, and new faults formed within the basin. It is likely that movement along one of the latter caused a largescale discrepancy in the present thickness of the Triassic rocks. Throughout most of the valley the surface of the pre-Triassic complex now lies several hundred feet below sea level. Over a large triangular area in the northeast part, however, the very irregular pre-Triassic surface lies more than 200 feet above sea level, and is actually exposed in many places. This uplifted block is bounded on the south by the Holyoke Range and extends northward between the Connecticut River and the east valley border as far as Northfield; it has been termed the Mount Toby triangle by Emerson. ${ }^{i}$

\footnotetext{
${ }^{2}$ Emerson, B. K., Geology of Massachusetts and Rhode Island: U. S. Geol. Survey Bull. 597, p. 129,1917 .
} 
TABLE 3.-Geologic time classification of United States Geological Survey

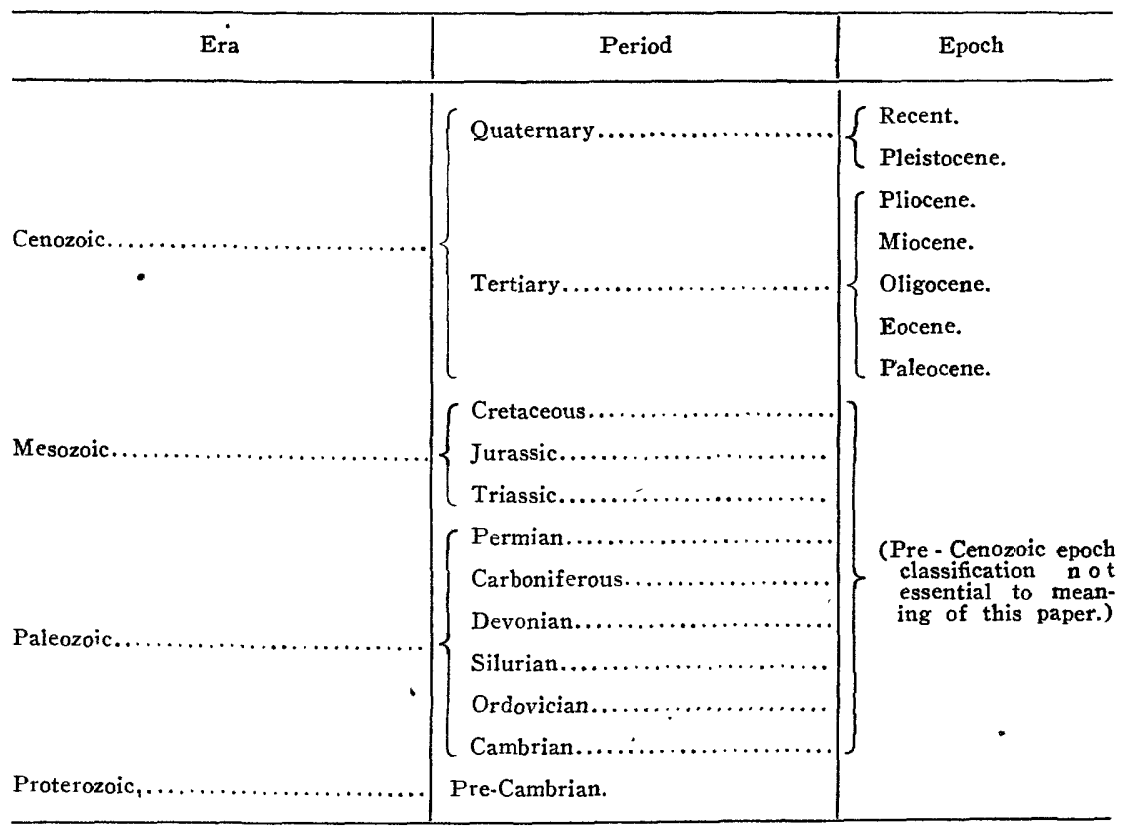

The eastward tilting of the Triassic strata, and the uplift of mountain masses that probably were larger than those in western Massachusetts today may be ascribed to the post-Triassic faulting. According to present concepts, this was followed by two great erosion intervals that occupied the remainder of the Mesozoic era and probably the early part of the succeeding Tertiary period. The so-called Fall Zone erosion cycle and the later New England Upland cycle, each of which ultimately led to the formation of a peneplain, are here grouped together and their activities considered as a unit. The processes active during each were essentially alike; furthermore, the Fall Zone peneplain probably does not exist in central western Massachusetts, having been. removed by erosion during development of the New England Upland peneplain. The ultimate result of these prolonged periods of erosion and degradation was the formation of the so-called New England Upland peneplain, a widespread, remarkably smooth plain, broken in only a few places by residual hills of moreresistant material. Well-preserved remnants of this surface now form a large part of the summit area of the Berkshire Hills. The Connecticut Valley did not then exist; its softer rocks lay at the same general level as the adjacent crystallines. The cycle of erosion was nearly completed.

A long period of gradual uplift, accompanied by a gentle southeasterly tilt, terminated the upland cycle. In response to this differential uplift, a system of major streams was formed on the peneplain surface. These streams adopted southerly, rather than southeasterly courses because of 
their partial adjustment to structure of the underlying bedrock; tributaries, as they worked headward, developed similar southerly courses, thus forming a pattern like the upward-reaching branches of a tree. The Connecticut River, having established its partly subsequent, partly consequent course on the bedrock and on the loose materials that mantled the peneplain surface, soon encountered bedrock everywhere in its downward cutting. In many places, its established course proved to be out of adjustment with respect to the distribution of hard and soft portions of the terrane. Where belts of very resistant rock were crossed, gorges were cut; where the rock was more easily removed, broad valleys eventually were formed. In this manner the Connecticut River was superimposed on the Holyoke-Mount Tom Range, as well as on the Deerfield-Mount Toby mass, both of which soon projected above the valley floor because of their superior resistance to erosion.

During the latter part of the Cenozoic era, this cycle of erosion had reached the stage at which a wide, flat valley and dominantly rounded, mature upland areas characterized the landscape of central-western Massachusetts, which probably was similar in many respects to that of the present time. The valley area was worn almost to sea level, whereas the areas underlain by the durable pre-Triassic crystalline rocks remained in a much retarded stage of the cycle. In its lower reaches, the Connecticut River was sluggish and essentially at grade.

These conditions were interrupted, however, by another regional uplift. The Connecticut was rejuvenated because of the lowering of base level and gradually intrenched itself into its broad, previously graded valley floor. A pronounced gorge, now below sea level, was developed through Massachusetts and Connecticut, and a wider trough, now occupied by Long Island Sound, was cut in the soft Cretaceous sediments south of the present Connecticut shore line. The uplift also caused the formation of gorges in major tributary streams, as well as in the lower reaches of minor tributaries. This renewed cutting process was the initial stage in yet another cycle of erosion, whose progress was halted, however, by the advent of the Pleistocene ice sheets.

\section{PLEISTOCENE GLACIATION}

\section{WORK OF THE ICE SHEETS}

The relatively, warm climate of the Tertiary period was supplanted at the beginning of the glacial epoch by colder, much more rigorous conditions. In response to this general change, great ice sheets gradually spread over northern North America, mantling even the highest mountains. Western Massachusetts was covered to considerable depths by such ice, which slowly moved in a southerly to southeasterly direction. Adthough it is generally recognized that the ice advanced and retreated several times, alternating with periods of warmer, interglacial climate, the 
evidence bearing on the details of this history is not so clear in New England as in other parts of the continent.

By the close of Tertiary time, the long-active processes of weathering probably had formed a thick, extensive blanket of soil and soft, rotted rock, similar to that now found in the unglaciated Piedmont region in certain of the southern states at the present time. As the ice sheet, whose maximum thickness was perhaps a mile or more, advanced over this soil cover, it experienced little difficulty in removing vast amounts of the relatively soft, yielding material, which became the principal source of the till. In most areas, such erosion was maintained until or even after fresh bedrock was encountered, as shown by the grooved and polished ledges so common wherever resistant rocks occur. In addition to the rounding and smoothing of bedrock hills, the ice was able to remove blocks of solid rock by plucking, particularly from the exposed ridges of jointed lava on the Holyoke-Mount Tom Range. The most significant amounts of bedrock removal, however, were accomplished in areas underlain by the relatively soft Triassic sediments, especially in areas where the ice was crowded hetween flanking hills or ridges. Even in such places, though, the ice was unable to effect any important general changes in the preglacial landscape.

Till was deposited during both advance and retreat of the ice sheets, and occurs chiefly as ground moraine, an unevenly distributed cover with slight topographic expression. No deposits definitely recognizable as end moraines have been found. The other chief occurrence of till is in the form of drumlins, the rounded, elliptical hills so numerous in the valley and in the eastern border area of the Berkshire Hills, where they rise to heights of $\mathrm{I} 5$ o feet or more. The till deposits to some extent reflect the nature of the nearby bedrock, as well as the probable amount of weathered material available to the ice. This is demonstrated by the contrast between the valley and highland tills. Although both are sandy, the highland till is looser, coarser, and more bouldery. The valley till, though undoubtedly of wide distribution, is now covered over large areas by later deposits; this buried till has been exposed in several places, however, by the cutting of the postglacial Connecticut River.

\section{CRUSTAL SUBSIDENCE}

A general subsidence of the land occurred during the glacial epoch, and probably reached a maximum of 200 to 300 feet. $^{8}$ The stream-cut valley of Long Island Sound was occupied by marine waters as the glacial ice withdrew. The preglacial gorge of the Connecticut River now lies below sea level as far north as the Mount Toby area. It cannot be stated with assurance that sinking of the land was due to the enormous weight of the

${ }^{8}$ Sharp, H. S., The physical history of the Connecticut shore line: Connecticut Geol. and Nat. Hist. Survey Bull, 46, p. 45, 1929. 
ice masses that lay upon it, but such a hypothesis is compatible with the meager data bearing on the question.

\section{DISAPPEARANCE OF THE LAST ICE SHEET}

The manner in which the last ice sheet disappeared fron New England has been the subject of considerable discussion for many years. ${ }^{9}$ Most earlier investigators favored the concept of a moving ice mass whose front receded in more or less orderly fashion because of melting in excess of forward motion. During its gradual northerly and northwesterly withdrawal, the ice front was thought to have adjusted itself to the increasing relief of the area by assuming lobate forms, one of these lobes having occupied the Connecticut Valley. A second and perhaps more recent hypothesis of ice removal is that of dissipation by stagnation. The active ice is assumed to have been bordered by a stagnant zone in which large blocks and masses of ice wasted away where they happened to be. Much disagreement exists about the extent of the stagnant ice at any time. Some students of New England glaciology believe that this zone was relatively narrow and retreated northward along with the front of the active ice, whereas others support the view that most of the ice south of the mountain barriers extending from the Adirondacks to Maine became stagnant as a unit soon after its maximum extension.

\section{FORMATION OF HIGH TERRACES}

Whatever the mode of disappearance of the last ice sheet, it seems certain that essentially stagnant masses of ice played an important role. Evidence for this lies in the presence of eskers and crevasse-fillings, commonly of branching pattern, as well as of heavily pitted kame terraces with well-preserved ice-contact faces. Excellent examples of these features lie along the valley edge west of Northfield, east and southeast of Montague, and along certain parts of the north side of the Holyoke Range. Terminal and recessional moraines, such as are normally deposited at the front edge of an active ice sheet, are either absent or very poorly developed throughout the region.

As the ice was disappearing from the Connecticut Valley area, large bodies of melt water accumulated in basins dammed by drift masses in the valley north of Middletown, Connecticut. The basin in Massachusetts was occupied by three connected lakes, and the nature of the sedimentation in each has had great effect in controlling the activity of the postglacial Connecticut River. The three melt-water bodies were named Lakes Springfield, Hadley, and Montague by Emerson. ${ }^{10}$ Lake Springfield occupied much of the valley south and east of the Holyoke-Mount Tom Range, the much smaller Lake Montague occupied the valley north

\footnotetext{
- See Bibliography, under section on Quaternary geology.

${ }^{10}$ Emerson, B. K., Geology of Old Hampshire County, Mass.: U. S. Geol. Survey Mon. 29. pp. $609-718,1898$.
} 
and east of the Deerfield-Mount Toby Range, and Lake Hadley lay over most of the remaining valley area.

Broad, flat-topped terraces were formed along the margins of the lakes by deposition of glacial sand and silt carried by melt-water streams. In general, these terraces reach altitudes of 220 to 240 feet in Lake Springfield, 300 to 330 feet in Lake Hadley, and 320 to 380 feet in Lake Montague, and show much more extensive development on the east side of the valley than on the west. Oustanding examples are the Montague Plain ( $7 \frac{1}{2}$ Greenfield quadrangle), Long Plain, south of Mount Toby (pl. 5), and the Springfield-Agawam Plain, including the Chicopee sand plain, adjacent to the Chicopee River. (See pl. I.) These marginal high terraces have been variously interpreted as deltas formed in essentially open bodies of water, ${ }^{11}$ as deposits in an estuary, ${ }^{12}$ and, to a certain extent, as ice-marginal features built before the lakes came into existence. ${ }^{13}$ Certain narrow, higher terraces appear to belong to the last category, although the writer is inclined to view most of the forms as delta-outwash plains, ${ }^{14}$ or deposits built out over and around lingering ice masses into bodies of open water beyond. Montague Plain and the Springfield-Agawam Plain are excellent examples of such forms, and consist of relatively coarse sediments carried by the torrential waters of the proglacial Millers and Chicopee Rivers, respectively. The sediments show fluvial bedding in the kettled parts of the terraces, deltaic bedding in most of the unkettled parts.

Extremely rapid deposition probably led to the development of gently sloping fans in the shoreward portions of the deltas. It is impossible to estimate the amount of ice present in the lake basin itself during the formation of these higher terraces, but it is certain that the terrace deposits ultimately filled up very large parts of Lakes Montague and Springfield. Similar forms were less well developed in Lake Hadley, probably because no large contributory drainage system was present.

\section{FORMATION OF LOW TERRACES}

Finer-grained sediments accumulated quietly on the lake bottoms. These included the well-known varved clays and silts of the region. Locally they are more than Ioo feet thick along the axis of the valley, but wedge out toward its edges; they are most widely distributed over the Lake Hadley basin, where encroachment by higher-level sand and gravel terraces was slight. In this basin, they form a very broad, gently undulating plain of deposition, the Hadley Plain, much of which lies at

\footnotetext{
II Emerson, B. K., op. cit., pp. 609-718, 1898.

12 Fairchild, H. L., Pleistocene marine submergence of the Connecticut and Hudson Valleys: Bull. Geol. Soc. America, vol. 25, pp. 219-242, 1914.

${ }^{13}$ Flint, R. F., The glacial geology of Connecticut: Connecticut Geol. and Nat. History Survey Bull. 47, pp. 80-104, 1930; Late-Pleistocene sequence in the Connecticut Valley: Geol. Soc. America Bull., vol. 44, pp. 981-982, 1933.

${ }^{14}$ Jahns, R. H., and Willard, M. E., Quaternary deposits in the Connecticut Valley, Massachusetts: Am. Jour. Sci., vol. 240, pp. 161-191, 265-287, 1942.
} 
altitudes of 160 to 180 feet. Small postlake dune areas comprise the only important sharply defined surface irregularities.

In areas where tributary streams entered the lakes, the varved silts and clays are overlain conformably by relatively thick deposits of coarser silt and sand. Such shoreward deposits lie at levels much lower than those of the high terraces previously mentioned, and form fan-like surfaces that slope gently away from the stream mouths and merge imperceptibly with deposits laid down in deeper, more quiet waters. Varved clays and silts compose the bulk of the quiet-water deposits, and in nearly all places along the banks of the Connecticut River where their base is exposed, they rest directly on bedrock; in places away from the river, however, they rest on till of variable thickness. Even in the deeperwater deposits, the varved sediments grade upward without break into considerable thicknesses of fine sand, a feature that is very well shown in a small area immediately north of Hatfield. The clays are unconformably overlain by flood-plain sands and silts in those places where the postglacial Connecticut River has trenched the lake-bottom deposits. In general, these lake-bottom sediments presumably rest against the outer faces of early-formed ice-contact deposits, but appear to extend for some distance beneath the later delta deposits. ${ }^{15}$

\section{POSTGLACIAL EROSION}

As the glacial ice melted from the highland areas, the processes of normal fluvial erosion became active once more. Most of the preglacial drainage pattern was restored, although the streams themselves were controlled by a new, slightly higher base level, particularly during the period in which the Connecticut Valley lakes were in existence. This slightly higher base level, due primarily to crustal subsidence during the glacial epoch (see pp. 21-23), probably had little effect on the erosive power and competency of the larger tributary streams, whose steep, - youthful profiles had been developed prior to glaciation in response to the late Tertiary uplift of the New England region. Further, the rather soft glacial drift, which mantled the upland areas and choked many of the gorges, offered little resistance to rapid removal by running water. The streams were torrential and debris laden at first because of their proximity to the melting ice, but subsequently they lost much of their volume and became more like the present streams. Since then most of their activity has been to erode the drift cover. With few exceptions, areas in which bedrock appears over much of the surface have been affected only slightly.

The draining of Lakes-Springfield, Hadley, and Montague, which may have been accomplished through the breaching of a drift dam at

15 Jahns, R. H., and Willard, M. E., op. cit. pp. 177-178, 181-188, 272-283, 1942. 
Rocky Hill, Conn., ${ }^{16}$ was followed by establishment of the postglacial Connecticut River, to which a detailed discussion is devoted in a succeeding section. Both the high marginal terraces and the lake-bottom plains, composed in large measure of rather loose sands and silts, have been much more susceptible to erosion than the heterogeneous, more compact till. Consequently, even small streams have achieved conspicuous results in their headward gully and ravine cutting. Long Plain Brook, south of the Mount Toby mass (see pl. 5), and Bennetts Brook (Northrield quadrangle) are examples of streams that have incised their channels into high sand and gravel terraces in this manner. The serrate cuter margins of many terraces may be ascribed to similar ravine cutting by smaller streams, and locally have been confused with ice-contact slopes. Where postglacial streams have not yet worked far headward, the original flat to gently undulating terrace surfaces are interrupted only by occasional dunes or by glacial kettles, such as those now occupied by Great Pond and Green Pond on the Montague Plain.

It is evident that all these processes of postglacial erosion are active in the Connecticut River basin today. They progress at rates which vary with meteorological conditions, and when the latter are more or less normal, the rates of erosion are low. When unusual conditions prevail, however, the rates may increase enormously, and under very severe weather conditions, such as periods of exceptionally heavy precipitation or very rapid melting of a thick snow cover, considerable erosion inay be accomplished by the much enlarged streams in a very short time.

\section{POSTGLACIAL CHANGES IN LEVEL}

\section{GENERAL FEATURES}

It is generally recognized that New England has been subjected to repeated changes of level in post-Pleistocene time. These changes of level have been of considerable importance in governing the behavior of the postglacial Connecticut River because of their effects on local and regional base levels, and for that reason they are treated here in some detail. Definite correlations between river activity and individual base-level changes are exceedingly difficult to make with any assurance, because of the extreme complexity of the factors involved, as well as the paucity of reliable basic data. The general aspects of the problem have been summarized by Johnson, ${ }^{17}$ who states:

The abstraction of vast qantities of water from the ocean to form the great ice sheets of the glacial period must have lowered the sea level, possibly as much as a few hundred feet; and the return of this water to the ocean consequent upon the

${ }^{16}$ Loughlin, G. F., The clays and clay industries of Connecticut: Connecticut Geol. and Nat. History Survey Bull. 4, p. 24, 1905. Flint, R. F., Late-Pleistocene sequence in the Connecticut Valley: Geol. Soc. America Bull., vol. 44, pp. 977-981, 1933.

17 Johnson, Douglas, The New England-Acadian shore line, pp. 131-132, New York, John Wiley and Sons, Inc., 1925. 
melting of the ice must similarly have raised sea level. The weight of the ice may have depressed the earth's crust beneath it, while beyond the ice margin, the crust may have been bulged upward in a low, broad arch due to the transfer in depth of material pressed out from beneath that part of the earth's crust which yielded under its burden of ice. When the ice melted, the depressed area would rise again; but, as Barrell has shown, the rising central area might carry the marginal bulges upward with it, causing a further rise of areas already appreciably elevated. Later these marginal areas might be expected to subside. The mass of the ice, by the attractive force which it exerted upon the waters of adjacent parts of the ocean, must materially have raised the sea level along coasts near to the ice margin; and with the disappearance of the ice sheets, the waters must have fallen. During these changes in the relative level of land and sea, there may have been others quite unrelated to glaciation, such as broad continental and suboceanic movements involving isostatic readjustment of large sections of the earth's crust, more limited compressive movements associated with earth shrinkage and often tending to destroy rather than to establish isostatic equilibrium, the rise of sea level due to partial filling of the ocean basins by sediments washed in from the lands, and possibly a further slow rise due to secular gain in the volume of ocean water.

Most of the above factors are to be correlated with the advance and subsequent wastage of a single ice sheet. That more than one such cycle occurred over New England is fairly certain; the complexities of changes in level increase accordingly. Nevertheless, the post-Pleistocene oscillations may be related to the waning of the last, or late Wisconsin ice sheet, and dealt with on that basis. They may be divided into two general categories-eustatic changes of sea level and crustal movement.

\section{EUSTATIC CHANGES OF SEA LEVEL}

Although it is generally agreed that sea level has risen since the climax of the last glaciation through the addition of melt water to the ocean bodies, the magnitude of the change appears to be cloaked in doubt. Many estimates have been submitted during the past century. Those most widely quoted have been made chiefly on theoretical grounds by Antevs ${ }^{18}$ and Daly. ${ }^{10}$ Daly believes that the sea level is now approximately $\mathrm{I} 32$ feet higher than at the time of maximum glaciation; Antevs, however, places his estimate at 290 to 305 feet. More recently, Flint ${ }^{20}$ has summarized existing opinions on the subject and has drawn comparison with his own observations in the Connecticut Valley. He estimates the amount to be probably much nearer 150 feet than the higher value suggested by Antevs, and bases this conclusion chiefly on the known excavation of present bedrock valleys and of Long Island Sound to depths of approximately 150 feet below sea level.

Considerable quantities of ice now exist in latitudes and altitudes

18 Antevs, Ernst. The last glaciation with special reference to the ice retreat in northeastern North America: Am. Geog. Soc., Research ser. no. 17, p. 81, 1928.

10 Daly, R. A., Pleistocene changes of level: Am. Jour. Sci, 5th ser., vol. 10, pp. 285, 312 , 1925.

${ }^{20}$ Flint, R. F., The glacial geology of Connecticut: Connecticut Geol, and Nat. History Survey Bull. 47, pp. 215-218, 1930.

$689520-47-3$ 
sufficiently high to maintain a perennial cover. It therefore seems likely that the present sea level is slightly lower than it was during interglacial ice-free periods or during preglacial late Tertiary time. Possible reductions in the capacity of the ocean basins, as well as secular gain in volume of ocean water, would tend to reduce this difference, but the magnitúde of such a reduction probably would be relatively small. It would appear, therefore, that the present position of the integrated drainage system far below sea level, as noted by Flint, is to be ascribed to crustal subsidence during the Pleistocene, inasmuch as the drainage was not similarly drowned with respect to the nearly equivalent sea level of late Tertiary time, but instead is known to have been engaged in active gorge cutting. The present position of bedrock drainage channels, therefore, appears to be of little value as a datum for measurement of postglacial eustatic rise in sea level, estimation of which seems to be attainable only through calculations that are chiefly theoretical.

\section{CRUSTAL MOVEMENT}

The so-called late-glacial and postglacial upwarping which has affected northeastern North America has been the subject of considerable study by many investigators, including Hitchcock, Upham, Baldwin, De Geer, Woodworth, Fairchild, Goldthwait, Horner, Antevs, Chalmers, Dana, Hatch, Johnson, Leverett, Stanley, Stone, Johnston, and Lougee. ${ }^{21}$ Late-glacial fossil-bearing marine clays have been found in the Lake Champlain region at altitudes of more than 400 feet above present sea level and in the Hudson Bay region at altitudes of 600 feet or more. The presence of similar clays in the St. Lawrence Valley and in coastal areas of Maine and New Hampshire has been recorded. The altitudes and geographic positions of the several occurrences indicate a noteworthy postglacial crustal uplift, the magnitude of which has increased steadily northward and westward. This movement may be the result of crustal adjustment caused by removal of the load of ice.

Other effects of this upwarp have been noted in the Champlain, St. Lawrence, and Great Lakes regions in the form of appreciably tilted proglacial lake terraces. Far less convincing, however, are the reported occurrences of "marine shore lines" and "marine benches," the profiles of which have been interpreted as indicating an uplifted and tilted marine plane. It has been demonstrated that many of these are of glaciofluvial or glaciolacustrine origin, and therefore not necessarily indicative of a single plane. Further, many of the areas once thought to have undergone marine inundation are now known to have contained bodies of fresh water only. The Connecticut Valley is an excellent example. Although many of the past observations are erroneous or mislcading, either because of their reconnaissance nature or because of the

21 See bibliography, under section on Quaternary geology. 
incorrect assumptions upon which their interpretations were based, nevertheless there is a sufficient amount of reliable data to justify the hypothesis of distinct postglacial crustal upwarp over most of northeastern North America. .

Evidence for this upwarp is present in the Massachusetts portion of the Connecticut Valley. Although considerable areas of the present highterrace surfaces were formed above the water plane of the valley lakes, which appear to have constituted one lake, and therefore do not furnish an accurate register of lake level, their outer, or more completely deltaic parts do integrate into a consistent lake-level profile that is unmistakable tilted from north to south, with a slope of slightly more than 4 feet a mile. The lake-bottom deposits also can be used to demonstrate tilt, but with greater difficulty and lack of assurance. Most of the broad plain of the Lake Hadley bottom, for example, is not a suitable datum because of the low, fanlike encroachment of the sands and silts supplied by the proglacial Deerfield River. Because that part of the plain east and northeast of Mount Warner was fairly free from such encroachment, however, it is reasonable to assume that it was therefore initially flat or nearly so. At the present time it slopes gently southward and southeastward, probably because of the postglacial tilt. Similar evidence appears to be more widespread in Connecticut, ${ }^{22}$ where the terraces of the late glacial sequence are developed more extensively; nevertheless, even there the possibility that the southward-sloping plains are due to initial deposition must be considered. In his recent study of the Quabbin Reservoir area in central Massachusetts (Belchertown I $5^{\prime}$ quadrangle), Balk ${ }^{23}$ has noted very extensive, even-topped, kettled terraces which slope southward with striking uniformity. The stirface of the terrace in the West Branch of the Swift River has an average fall of about $9 \frac{1}{2}$ feet per mile and the surface of the terraces in the Middle and East Branches fall 7 feet per mile for distances of 8 and 12 miles respectively. That much of the slope of these terraces was due to original deposition is evident, but crustal tilt may well have been an appreciable contributory factor.

\section{ChANGES OF LEVEL IN THE CONNECTICUT VALLEY}

Convincing evidence for two types of postglacial level changes is found in the Connecticut Valley. These changes were due to eustatic rise in sea level, as well as to crustal movement that resulted in uplift and southward to southeastward tilt. It seems certain that these two processes operated simultaneously, but their respective rates at any time were dependent upon so many widespread and little-known variables that they can be scarcely more than conjectural. The net cumulative

22 Flint, R. F.. Deglaciation of the Connecticut Valley: Am. Jour. Sci., 5th ser., vol. 24, p. 152. 1932 .

Balk, Robert, Personal communication, April 1940. 
effects of the two processes, however, are capable of evaluation in a few places.

Remains of trees as weil as of fresh-water and tidal-marsh vegetation in postglacial sand, clay, and peat beds now below sea level in the coastal region of Connecticut ${ }^{24}$ have been reported. Similar occurrences in the Long Island and New York City areas are recorded. They consitute compelling evidence that the sea once stood lower than its present position, and therefore that, in these areas, crustal uplift has been unable to keep pace with the eustatic rise of seal level during postglacial time. The present depth of the vegetation below sea-level gives a minimum value of the net submergence; this amounts to only a few feet along much of the Connecticut coast. The apparent southward increase in the depths of this vegetation below sea level, as recorded in the literature, is entirely in keeping with the concept of a southerly crustal tilt. In addition to the botanical evidence, Flint ${ }^{25}$ has noted the presence of submerged glaciolacustrine terraces in the New Haven region. Far less convincing, however, are the varved clays which lie below sea level, for these could have been formed normally in lakes whose bottoms extended below sea level, but whose waters were fresh.

The large area between the coastal region of Connecticut and the Champlain and St. Lawrence Valleys has apparently never been inundated by marine waters in Recent times. It is not known to contain fossiliferous marine clays above present sea level or beds of postglacial subaerial character now covered by sea water. In other words, features of value in directly determining the magnitude of net changes of level are absent in the Connecticut Valley north of the coastal area. If slightly curved, parabolic profiles are plotted, however, to connect the tops of known elevated marine clays and the bases of known submerged zones of nonmarine vegetation, and if the clays and vegetation are assumed to have been contemporaneous, the approximation of an early Recent datum plane is obtained. It is inaccurate insofar as two other conditions are concerned. First, the tops of the marine clays probably lay below the early Recent level of the sea. The depth of the water in which they were formed, however, may not have been very great, if we accept certain apparently valid correlations with marine shore-line features. Second, the zones of vegetation lay at various altitudes above the early Recent sea level. That this factor probably was small is indicated by the rather low relief of the areas in which these zones have been found, as well as by the fact that many of the same plant forms exist today in tidal marshes.

24 For discussions of individual occurrences, together with appropriate references, see: "Flint, R. F., The glacial geology of Connecticut: Connecticut Geol. and Nat. History Survey Bull. 47, pp. 216-218, 1930. Sharp, H. S., The physical history of the Connecticut shore line: Connecticut Geol. and Nat. History Survey Bull. 46, pp. 45-49, 1929.

25 Flint, R. F., op. cit., p. 216, 1930. 
Such hypothetical profiles, in spite of their approximate character, are nevertheless useful in interpreting within certain limits the zone wherein postglacial crustal uplift has been equal in magnitude to the eustatic rise of sea level. So far as the Connecticut Valley is concerned, this zone appears to trend east and west from a position probably not far north of Hartford, Connecticut. It is not to be confused with the so-called hingeline or zero isobase of crustal upwarp, which undoubtedly lies a considerable distance to the south; it represents, rather, a belt north of which crustal uplif.t has been greater than the eustatic rise of sea level. The net effect on the Connecticut River in Massachusetts has been, therefore, a lowering of its base level, as well as a progressive increase in the slope of its profile during Recent geologic time.

\section{DEVELOPMENT OF THE POSTGLACIAI CONNECTICUT RIVER}

\section{POSTGLACIAL PHYSIOGRAPHY}

\section{ESTABLISHMENT OF A POSTGLACIAL COURSE}

The Connecticut River began its most recent cycle of development after the disappearance of the last ice remnants and the draining of the late glacial lakes of the valley. Because the lakes probably were maintained by a barrier of drift, ${ }^{26}$ rather than bedrock, their draining must have been a relatively rapid process. As they became shallower and narrower, and the greater part of the lake bottoms emerged, a definite stream formed, which became the Connecticut River. This stream received the drainage from the more northerly parts of its present basin area, which were perhaps occupied by ice.

It seems evident that the Connecticut, although once again in existence as a river, had no chance to follow exactly its preglacial course, most or all of which was buried under considerable thicknesses of glacial and proglacial debris. It took its new course, rather, as a newly formed consequent stream on deposits of the glacial sequence, and as súch it followed the lowest parts of the lake bottoms consistent with drainage through sags in higher intervening areas. It may be assumed that the present route of the Connecticut River in Massachusetts corresponds closely over certain areas to its preglacial course, but in other areas its present route is distinctly new. These differences, together with the varied topography of the valley itself, allow a sixfold areal division of the river valley; in each division the postglacial Connecticut has reacted to its environment in a different way. From north to south, these areas are here termed the Northfield Meadows, the Turners Falls Gorge, the

\footnotetext{
${ }^{26}$ Loughlin, G. F., The clays and clay industries of Connecticut: Connecticut Geol. and Nat. History Survey Bull. 4, p. 24, 1905. Flint, R. F., Late-Pleistocene sequence in the Connecticut Valley: Geol. Soc. America Bull., vol. 44, pp. 977-981, 1933.
} 
Montague Meadows, the Hadley-Hatfield Meadows, the Holyoke Narrows, and the Springfield-Willimansett Meadows. (See pl. 3.)

\section{NORTHFIELD MEADOWS}

The Connecticut River tended to develop a meandering course as it flowed along the narrow strip of deposits exposed in the bottom of former Lake Montague in the north end of the valley. This was probably due in part to the presence of a bedrock threshold in the vicinity of Turners Falls; and in part to the debris-laden nature of the waters, which must have been actively supplied with glacial outwash from melting ice in some areas to the north. A third significant factor, more difficult to interpret accurately, is the relatively slight amount of southward crustal tilt that may have occurred at that time. The net effect, however, appears to have caused the river to flow at or nearly at grade.

As the extent of its lateral swings increased, the Connecticut was soon slowed appreciably because it impinged against the fronts of high flanking terraces and, of greater importance, against-ledges of bedrock. Bedrock exposures lie at or immediately adjacent to the positions of its widest lateral swings, and actually form the river bank northeast of Munns Ferry and opposite Pine Meadow (Northfield quadrangle). Because of these features, the Northfield Meadows area has an average width of only about a mile. It extends from the state boundary southward to the French King narrows (Millers Falls quadrangle), a distance of more than 8 miles. (See pl. 3.)

'It seems likely that the Connecticut River now follows much the same general course through the Northfield Meadows as that which it occupied during preglacial time, although its present bottom probably lies considerably above its preglacial bottom. The river does not flow on bedrock at any place in this area, so far as is known. . Given sufficient time, possibly with a lowering of base level, the river and its tributaries doubtless would ultimately remove the glacial and Recent fluvial deposits from this part of the valley and once more expose the gorgelike preglacial drainage pattern.

\section{TURNERS FALLS GORGE}

At the French King narrows, the beginning of the Turners Falls Gorge, all meadow areas of appreciable width disappear and are lacking for about 7 miles down the winding course of the river. Nearly all of this gorge section has bedrock on at least one side, and between the narrows immediately southeast of Turners Falls and the mouth of the Deerfield River ( $7^{1 / 2}$-minute Greenfield quadrangle) the Connecticut flows almost continuously on bedrock. The abrupt transition from the Northfield Meadows area to the gorge is striking. The genesis of the latter feature raises an interesting question, because its influence on the Recent activity of the Connecticut River has been profound. 
Emerson ${ }^{27}$ has demonstrated the Recent origin of this gorge, and makes the following statement about the probable preglacial course of the river:

The old bed of the Connecticut runs due south from Northfield Farms past Millers Falls, and thence southwest to join its present bed at the mouth of Sawmill River, in Montague. This course is marked by a line of kettle holes $* * *$ along the plain north of Millers River, by the sharp bend of the latter, and by the deep erosion basin that extends south from it. Farther on it is continued by the line of large kettle holes of which Green Pond and Lake Pleasant are the most important, and by the course of Pond Brook and Sawmill River.

These features, together with the distribution of bedrock in the area, leave little reason to doubt this position of the preglacial course shown in plates $I$ and 3 .

The reason for the diversion seems clear. Before the draining of glacial Lake Montague, the broadest part of its basin was almost completely filled by sands and gravels from the torrential waters of the lateglacial Millers River. These deposits, in large part deltaic, formed the Montague Plain, the steep front of which extends northward and northwestward from Montague past the west slope of Wills Hill to Turners Falls ( $7 \mathrm{I}^{1 / 2}$ Greenfield quadrangle). 'They completely covered the old bed of the Connecticut, in which a few large ice masses yet lay, and extended to the north, west, and southwest with gently sloping surface. With the draining of Lake Montague, the consequent Connecticut River followed the northern edge of this plain, where it abuts the higher bedrock hills, and cut its circuitous course along this contact past the crossing of a sandstone reef near Turners Falls, thence southward between the trap range (Rocky Mountain) and the bottom deposits of Lake Montague. Subsequently, its bed was entirely superimposed on bedrock for long distances. The Millers River now makes a great bend at Millers Falls, flows northward through a steep-sided, flat-floored valley cut in its own proglacial delta and thence through a narrow rock gorge at French King Bridge to join the Connecticut.

\section{MONTAGUE MEADOWS}

As in the Northfield Meadows, the Recent Connecticut River has been restricted in its lateral swings in the $7 / 2$-mile stretch between the mouth of the Deerfield River and Sunderland. Its ability to form even narrow meadow areas at the expense of glacial lake-bottom deposits is due to the fact that it follows a possible preglacial course of the Deerfield River from the New Haven railroad bridge at Montague City to the mouth of the Sawmill River ( $71 / 2$ ' Greenfield quadrange), and its own preglacial course from that point to Sunderland. For this reason, the river now exposes bedrock in several places along its banks, but does not seem to have a bottom of bedrock throughout the area. The maximum width of the

27 Emerson, B. K., Geology of old Hampshire County, Mass.: U. S. Geol. Survey Mon. 29, pp. 625-629. 1898. 
Montague Meadows is not more than a mile, because the preglacial valley was narrow, and the average width is half a mile or less.

\section{HADLEY-HATFIELD MEADOWS}

As the early Recent Connecticut issued from the constricted valley at Sunderland, it began to develop a long-continued series of broad meanders upon the wide, almost flat bottom of glacial Lake Hadley. Several scars produced by these meanders are now beautifully preserved as crescentic scarps. (See pl. 5.) Its first course probably did not depart greatly from that held in the late Tertiary. As suggested by Emerson, ${ }^{28}$ the river apparently followed the lowest areas in the old lake bottom to the preglacial gap through the Holyoke-Mount Tom Range about I2 miles from Sunderland. Higher-level glacial deposits prevented the adoption of a course down the Westfield Plain west of Mount Tom. (See pl. I.) The river apparently has been confined laterally by bedrock in but one small area within these meadows. Northwest of Mount Warner, three ledges of Triassic sandstone are exposed on the banks at sharp bends, and similar material forms a prominent ridge north of Hatfield on the west side of the river. Other, less effective barriers to its lateral swing are the large till masses on the west edge of the meadows area in the Easthampton quadrangle, as well as the high terraces which form thin veneers over bedrock at the base of Mount Holyoke.

The Connecticut has thus formed between Sugarloaf and the HolyokeMount Tom Range extensive meadow or terrace and flood-plain areas, which commonly reach widths of a mile and a half and are more than 3 miles wide in the vicinity of Hadley and in the oxbow area immediately north of Mount Tom Junction (Mount Toby, Mount Holyoke, and Easthampton quadrangles). Although it includes many individually named meadows, the entire area is here termed the Hadley-Hatfield Meadows. (See pl. 3.) It embraces some of the most fertile agricultural lands in New England, and is well known for the beauty of its landscape. (See pl. 4.) It is one of the areas most seriously affected by recent floods, and as such is treated in greater detail in another section.

\section{HOLYOKE NARROWS}

The Connecticut follows a constricted, gorgelike course for 7 miles downstream from Mount Tom Junction to the rapids at Holyoke. This stretch, the Holyoke Narrows, is divisible genetically into two distinct parts. As explained in the section on the physiographic development of the Connecticut Valley, the gap through the Holyoke-Mount Tom Range is of preglacial origin, and for this reason the river flows between walls of bedrock but is not bottomed by it in the part of the Holyoke Narrows north of Smiths Ferry (Mount Holyoke quadrangle). South of that

23 Emerson, B. K., op. cit., p. 733, 1898. 


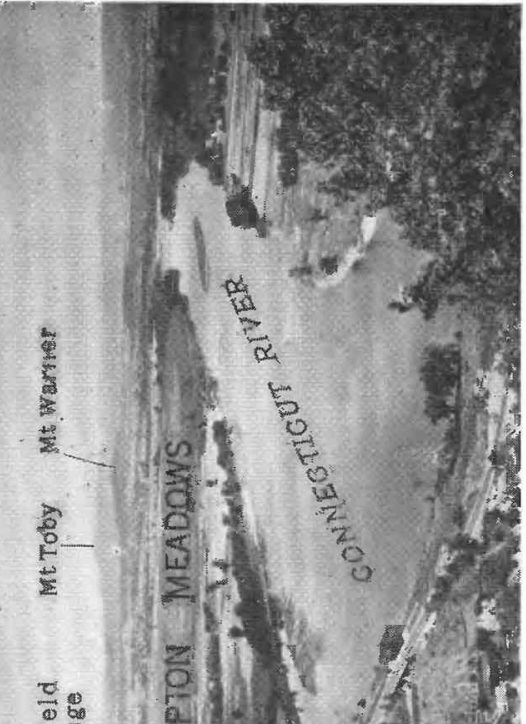

$\therefore$ : क्ष

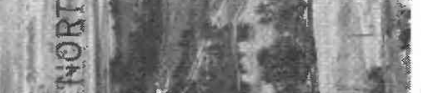

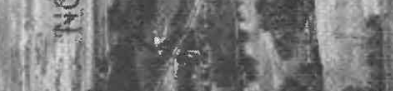

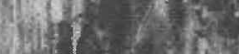

(1) 1 (1)

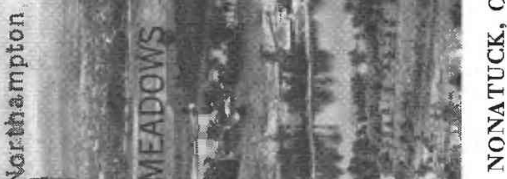

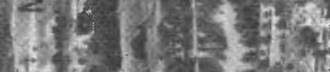

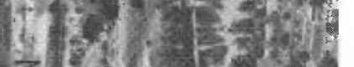

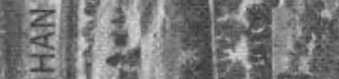

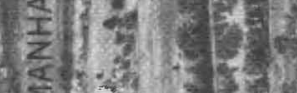

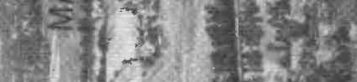

7. 6 का के

(15) $\sqrt{1045}$

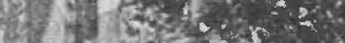

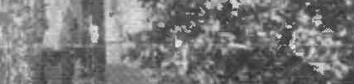

9.1 4 or atos

(1) $5(2)$

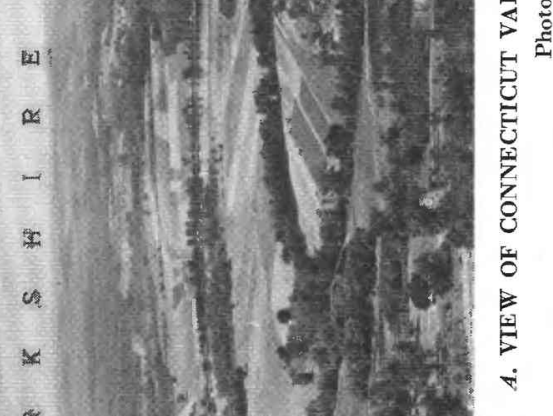

\& $(5)$ a

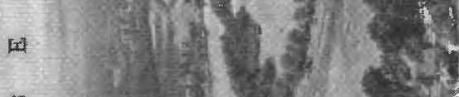

m

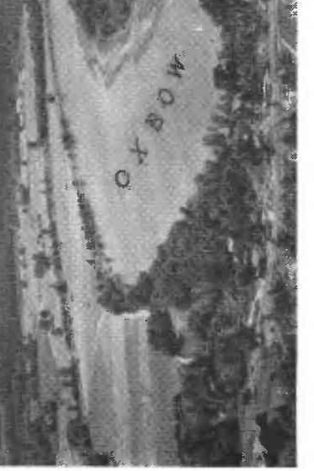

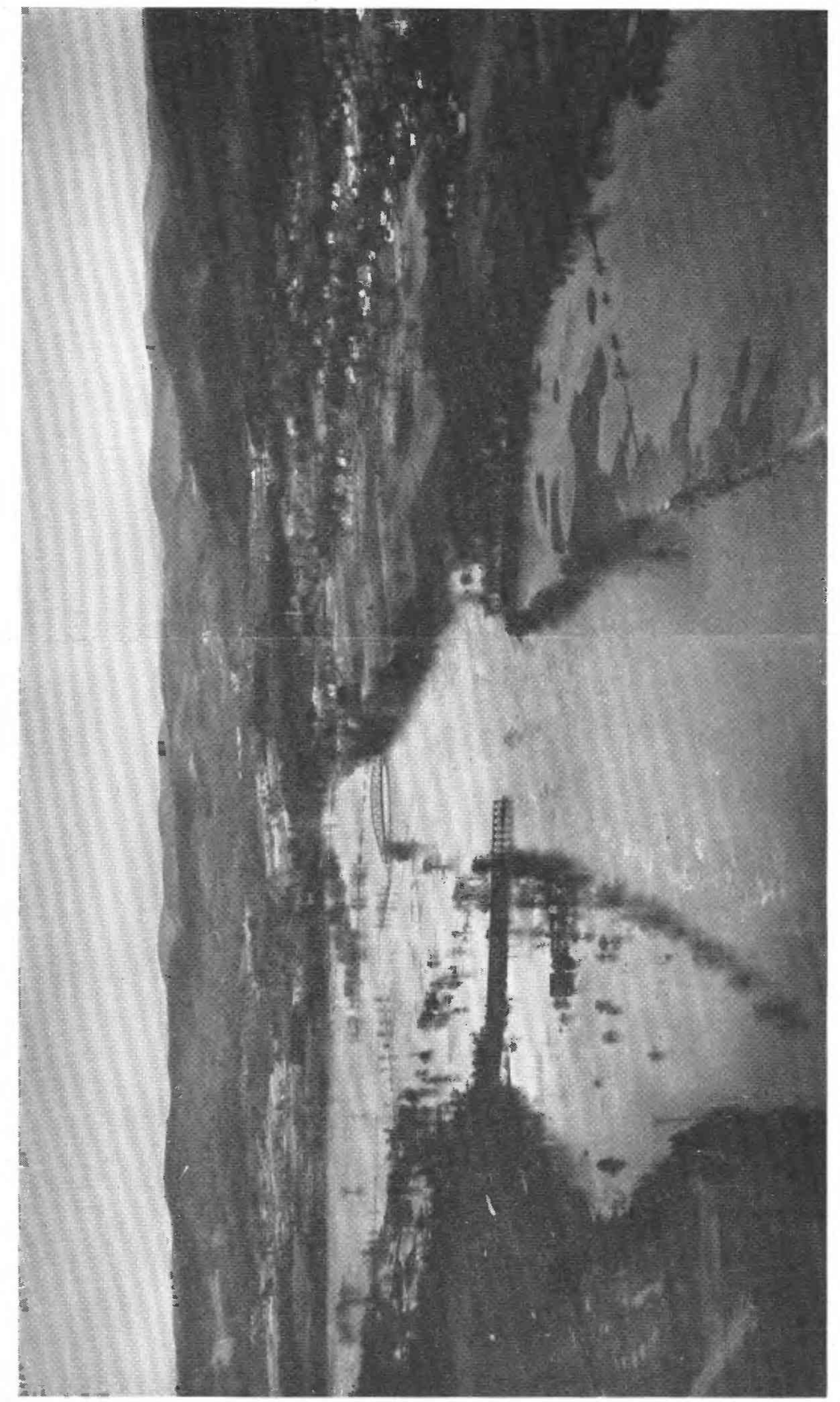

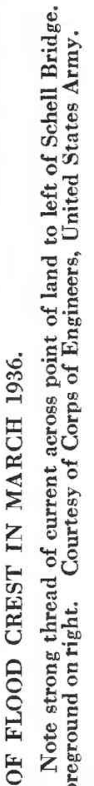

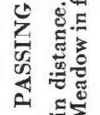

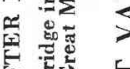

क ติ

政

政

8

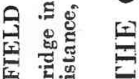

政

2

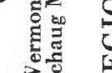

बूल

迹

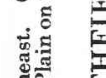

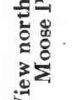

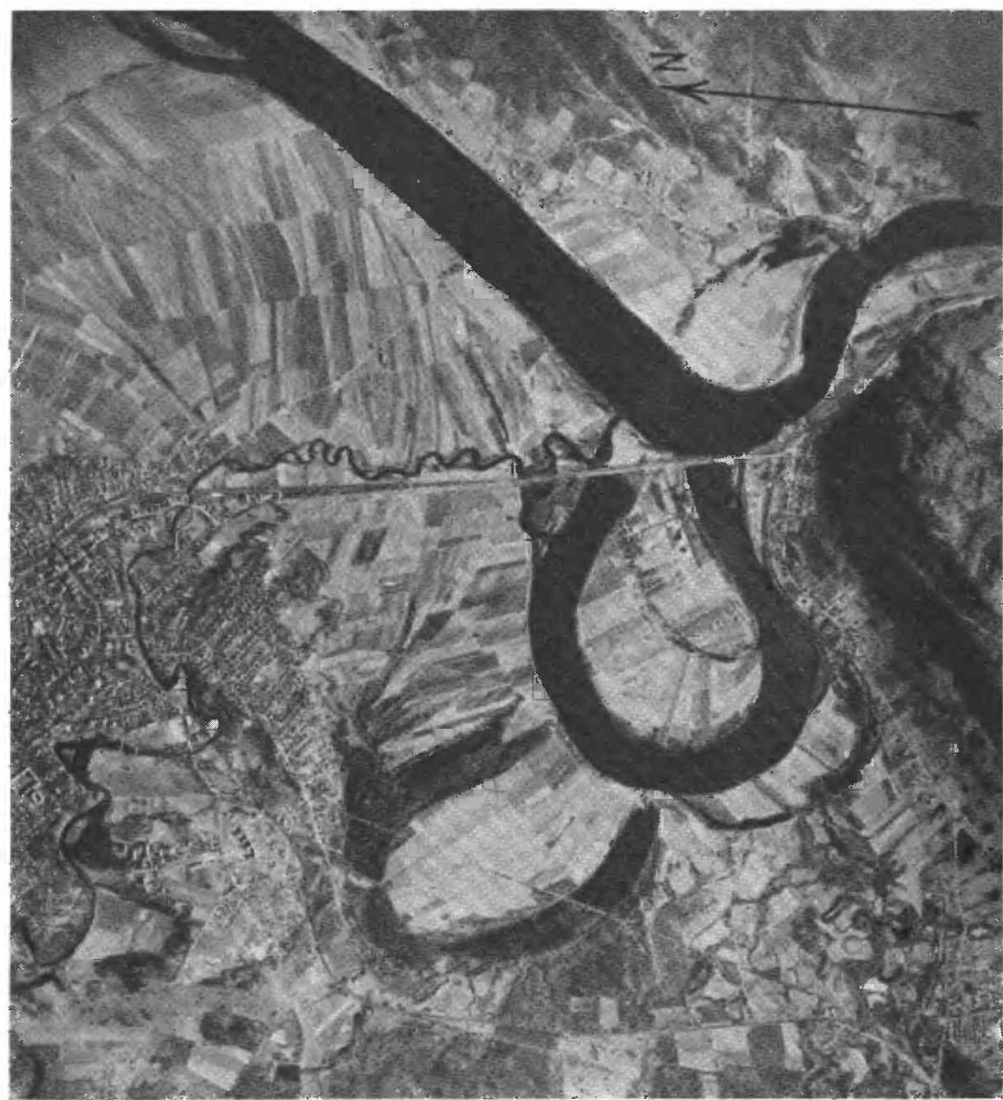



point, however, conditions similar to those at Turners Falls made the river flow directly on bedrock in a gorge of Recent origin.

The large delta of the preglacial Chicopee River filled in much of northern Lake Springfield to form the Springfield-Agawam Plain (pl. r) and buried the preglacial bed of the Connecticut River in the same way as the delta of the Millers River did farther north. Two possible routes of this preglacial bed, as suggested by Emerson, ${ }^{29}$ are indicated in plates $I$ and 3. Both are based on scanty data, and it is regretted that time did not permit as detailed a restudy of this area as was possible for the Montague Plain diversion. It is evident, however, that the preglacial bed lies some distance east of the present river channel, and possibly rejoins it in the vicinity of Springfield. With the disappearance of Lake Springfield, the Connecticut River was diverted from its former course at Smiths Ferry, and flowed between lake-bottom deposits on the east and the Mount Tom Range on the west; eventually it was superimposed on bedrock over much of the distance.

\section{SPRINGFIELD-WILLIMANSETT MEADOWS}

For the I 2 miles from Holyoke to the Connecticut State line, the area of Recent river activity broadens to widths of $\mathrm{I}$ to 2 miles. It is bordered on the east by the Chicopee River delta and on the west by lake-bottom deposits, deltaic sands of higher level, and scattered till masses. Bedrock is present, but has had little apparent effect on the river's course. The Willimansett Meadows north of Springfield almost certainly are a continuation of the Recent river course as developed north of Holyoke, as they lie west of the preglacial channel of the Connecticut. South of Springfield the Connecticut probably follows the general position of its preglacial channel within reasonable limits. It should be pointed out, however, that not far southward, in the Thompsonville-Windsor Locks area, Conn., the river again follows a Recent rock-bottomed course about 2 miles west of its preglacial path. ${ }^{30}$

\section{SUMMARY OF POSTGLACIAL PHYSIOGRAPHY}

The maximum width of flood-plain and terrace areas of the Connecticut River has been controlled during Recent times by the distribution of bedrock beneath or adjacent to the river channels. In those areas where the river has regained its preglacial gorge, it now flows on glacial sediments at an appreciable height above the rock floor of the gorge. Where the gorge was narrow and deep, the upper parts of its walls have confined the postglacial river within rather narrow limits, as in the Northfield Meadows and in parts of the Montague Meadows. Where the gorge or valley was sufficiently wide and shallow to be buried by glacial sediments

\footnotetext{
${ }^{29}$ Emerson, B. K., Geology of old Hampshire County, Mass.: U. S. Geol. Survey Mon. 29, pp. 513-515, 1898.

30 Flint, R. F., Late-Pleistocene sequence in the Connecticut Valley: Geol. Soc. America Bull., vol. 44, p. 984, 1933.
} 
over large areas, the postglacial river meandered broadly, as in the Hadley-Hatfield Meadows.

In those areas, however, where the river was forced from its preglacial gorge, its new channel has been cut into bedrock, with the development of rapids and falls. Each of these postglacial rock channels acts as a spillway in controlling the local base level of the river as far upstream as the next spillway. The three spillways that affect the region here discussed are, from north to south, the Turners Falls Gorge, the lower part of the Holyoke Narrows, and the Thompsonville Narrows in Connecticut just south of the State line. They are not to be confused with the larger, more spectacular gaps through the Holyoke-Mount Tom Range and between Mount Toby and the Deerfield Range, which are of Tertiary origin. These gaps have rock walls but are not bottomed by bedrock, and accordingly have had little effect on the local base levels of the present Connecticut River.

\section{TERRACES AND FLOOD PLAINS}

Throughout this report active flood plains are distinguished from river terraces, which represent older flood plains that are no longer active.

In his studies of the Connecticut Valley in Massachusetts, Emerson ${ }^{31}$ recognized and mapped four normal erosion levels in the areas occupied by the river since the glacial epoch. He contributed important observations and theoretical deductions concerning their origin, which have done much to clarify the meaning of many of their features. He was handicapped, however, by a lack of accurate and detailed base maps, especially for vertical control, and thus some of his terrace correlations and classifications now appear to be erroneous. The recently surveyed $7 \frac{1}{2}-$-minute quadrangle maps with Io-foot contours are now available for the valley area. (See pl. 3.) These new maps have served as excellent bases for the surveying of the areas affected by the levels of erosion. Most of the areas appear to be at one of five, rather than at one of four normal levels, and an additional one is at an anomalously high level. (See table 4 and fig. 2.)

TABLE 4.-Connecticut River terrace and flood-plain levels in Massachusetts

\begin{tabular}{|c|c|c|c|}
\hline \multirow[t]{2}{*}{ Level } & \multicolumn{3}{|c|}{$\begin{array}{l}\text { Height of surface above } \\
\text { mean river level (feet) }\end{array}$} \\
\hline & Low & High & General \\
\hline Lily Pond terrace, northward from Turners Falls.. & 76 & 84 & 80 \\
\hline 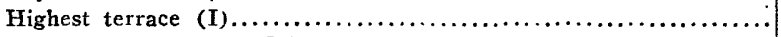 & 43 & 52 & 49 \\
\hline 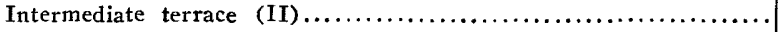 & 36 & 33 & 37 \\
\hline 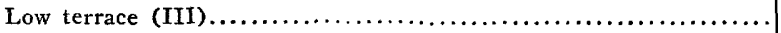 & 27 & 33 & 30 \\
\hline 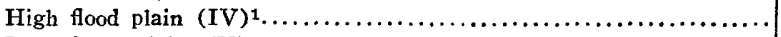 & 17 & 21 & .18 \\
\hline Low flood plain (V) $\ldots \ldots \ldots \ldots \ldots \ldots \ldots$ & 8 & 12 & 10 \\
\hline 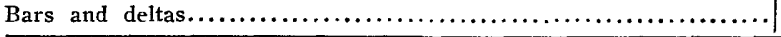 & \multicolumn{3}{|c|}{ Various elevations'below (V) } \\
\hline
\end{tabular}

'Includes certain areas mapped by Emerson as "bars and incomplete terraces"; is termed a flood plain because of its occupation by floodwaters a number of times each century.

31 Emerson, B. K., Geology of old Hampshire County, Mass.: U. S. Geol. Survey Mon. 29, pp. 725-733, 1898; U. S. Geol. Survey Geol. Atlas, Holyoke Folio (no. 50), 1898. 
The altitudes as shown in the table are the result of measurements obtained at I I9 points by hand leveling from bench marks or other points of known altitude. It is felt that these measurements, together with observations from each point, have served to establish the general height of approximately 80 percent of the terrace and flood-plain area in the main river valley south of Turners Falls. The figures given in the columns headed "Low" and "High" are reasonably accurate minima and maxima for the unscoured surfaces of their respective features. It is important to note that the figures under the column headed "General" do not represent mere numerical averages, but instead indicate within a few feet the altitude of nearly all portions of their respective flood-plain or terrace surfaces. Finally, it should be emphasized that there is a distinct gap between the maximum altitude of each level and the minimum altitude of the one immediately above. Small terrace remnants whose altitudes fall within' such gaps do exist, but are not common and are absent entirely over large areas. In short, a tentative fivefold division of the normal Connecticut River terraces and flood plains in Massachusetts seems empirically justified at this time, and is useful in the description of the forms involved. The writer hopes to continue his measurements in greater detail in order to establish and define more clearly the nature of this fivefold division.

\section{LILY POND TERRACE}

Immediately east of Turners Falls lies a narrow but prominent ridge of Triassic sandstone and shale that forms the southern wall of Bartons Cove. (See $7^{1 / 2} 2^{\prime}$ Greenfield quadrangle.) In this rock ridge are clearly preserved the scarps, plunge pools, and short, deep recessional canyons of two large waterfalls. These features have been attributed to the early Recent Connecticut River, ${ }^{32}$ which at one time must have flowed over the bedrock barrier with considerable fall. The waterfalls were successively abandoned, however, when the river stripped the coarse sands of the Millers River delta f.rom a more westerly, lower-lying gap in the ridge, through which it flows at the present time; this gap is known as "The Narrows."

A high terrace, about 80 feet above the present Connecticut, extends upstream from the lips of the abandoned waterfalls to points considerably north of the Massachusetts State line. This is the Lily Pond terrace of Emerson, ${ }^{33}$ apparently considered by him to indicate deposition during a late shallow stage of Lake Montague. The terrace was named from the small pond at the base of the higher waterfall, but the pond has since coalesced with Bartons Cove because of water storage behind the dam at Turners Falls. A normal fluvial origin for this terrace seems to be a more reasonable interpretation, chiefly because

32 Emerson, B. K., op. cit. pp. 724-725, 1898. Jefferson, M. S. W., The postglacial Connecticut at Turners Falls: Jour. Geol., vol. 6, pp. 463-472, 1898.

as Emerson, B. K., op. cit., p. 724, 1898. 
1. The terrace top lies about 25 to 30 feet below the level of the clay-bearing lake-bottom plain in the Northfield area.

2. The terrace surfaces appear to be similar to those of the high normal terrace (I) to the south.

3. The rather coarse materials of which the terrace is formed are much like those in terrace I; where varved clays are present, they underlie the terrace sequences with an erosional unconformity, and represent true bottom deposits of Lake Montague.

The distribution of the Lily Pond terrace is shown in a general way on plate IO. $^{34}$ It is of course absent south of Turners Falls. Its broadest development appears in the Northfield quadrangle as Cow Plain and the Second Moose Plain. (See pl. 4,C, left foreground.) Because of the great height of this terrace, it probably never has been inundated by Connecticut River flood waters since the abandonment of the waterfalls east of Turners Falls, a period of at least several thousand years. ${ }^{\mathbf{3 5}}$ ' .

\section{OTHER TERRACES AND FLOOD PLAINS}

GENERAL FEATURES

Where extensively developed, the normal terraces and flood plains appear as a series of broad, low steps that rise on either side of the river. Their surfaces, where uninterrupted by other features, are gently undulatory, commonly with very low slopes away from the river. Such slopes appear to be due to the following forms, either singly or in combination: (I) Natural levees on outer edge; (2) Abandoned and partly filled meander channels on inner edge ; (3) Similarly abandoned tributary channels.

Where natural levees are well developed, the transverse profile of much of a given terrace or flood-plain surface is commonly concave upward; where old meander channels are still clearly preserved, the transverse profile has a more uniform slope, and may be convex upward in that part farthest from the river. These variations in type of slope are slight but have been important in controlling loci of maximum erosion and deposition during floods.

The junctions of different terrace or flood-plain levels are commonly steep, sharply defined scarps, the height of which varies from place to place, but which in general closely approximates ro feet. (See pls. 6, A, I4, B.) These scarps, which have been dissected but little by erosion subsequent to their development, are in many places distinctly arcuate and doubtless are old meander scars. (See pl. 5.) The best examples are some scarps that have been cut into the glacial lake-bottom terraces; these mark lateral limits of erosion by the postglacial Connecticut River. A few terraces are succeeded by terraces of lower level in a downstream

\footnotetext{
${ }^{34} \mathrm{R}$. J. Lougee, in a personal communication, reports another higher early Recent terrace in southern New Hampshire, but it is not preserved in Massachusetts.

${ }^{35}$ Justification for this estimate is given on page 40 .
} 
direction rather than riverward; at such places the junction is not a scarp but takes the form of a more gently sloping zone of heavy scour.

Each individual surface slopes gently to the south at nearly the same angle as the river. Detailed measurements suggest slight southward convergences of the river profile with profiles of the terrace groups; the exact nature and amounts of these convergences are not known, however, and may be neglected so far as recent flood studies are concerned. Drainage of most terraces is by very small streams, which flow southward; in many places these are parallel to the Connecticut for long distances, and empty into old oxbows, larger streams, or the Connecticut itself. Most of the larger streams that enter the meadow areas flow along the base of the nearest scarp before discharging into the Connecticut. Excellent examples are Dug Brook and Russellville Brook in the Mount Toby quadrangle, Fort River and both Mill Rivers in the Mount Holyoke quadrangle, and Threemile Brook in the Springfield South quadrangle. Where such streams are absent, the inner margins of terraces are not uncommonly marked by elongate swamps.

\section{MODES OF ORIGIN}

The surface undulations on most terraces and flood plains are not distributed at random but follow a definite pattern. Close inspection reveals low, closely spaced parallel ridges, rudely curved to conform with the curvature of the river if they lie on a flood plain, or with the curvature of the inner scarp if on a terrace. These "scrolls" ${ }^{36}$ are the elements of "meander plains" formed by lateral accretion on the inner sides of meanders. This process has been described in some detail by Emerson, ${ }^{37}$ who traced the history of individual scrolls from their inception as river bars through their development as elongated islands to their incorporation into the adjacent meander plains. The scrolls of the Northampton Meadows, as seen from Mount Holyoke, stand out distinctly when the sun is low on the horizon or, better, after a heavy rain has caused the accumulation of ponded water in the narrow interscroll depressions. (See pl. $4, B$.)

Despite the common occurrence of scrolls and the evident origin of most Connecticut Valley meadow areas as meander plains, a cover of flood-plain sands and silts, the deposits of overbank floods, is nearly everywhere present. The thickness of this cover seems to have a remarkably slight effect on the preservation of scroll configuration on the present surfaces. (See pls. $4, A$, I I, $B$.)

Figure 2 illustrates the probable mutual relations of the present riverterrace and flood-plain levels, as well as three steps in their earlier de-

${ }^{36}$ Melton, F. A., An empirical classification of flood-plain streams: Geog. Rev., vol. 26, pp. $594-595,1936$.

${ }^{37}$ Emerson, B. K., Geology of old Hampshire County, Massachusetts: U. S. Geol. Survey Mon. 29, pp. 726-727, 731-733, 1898. 
velopment. No attempt is made to show internal structure, and the vertical scale is exaggerated for the sake of clarity. In section $A$ the postglacial Connecticut has cut a shallow trough into sediments of the late glacial sequence, and has formed a broad flood plain (I) at nearly equal elevations on both sides of the trough. Section B indicates a considerably later stage, in which the river has widened its original trough at the expense of the glacial deposits, in addition to removing much of its earlier flood plains (I), presumably by lateral corrasion and downward scour. A lower flood plain (II) has been developed, but is itself being attacked by the river in favor of a newer, still lower flood plain (III). A part of $\mathrm{I}$ is preserved as a terrace.
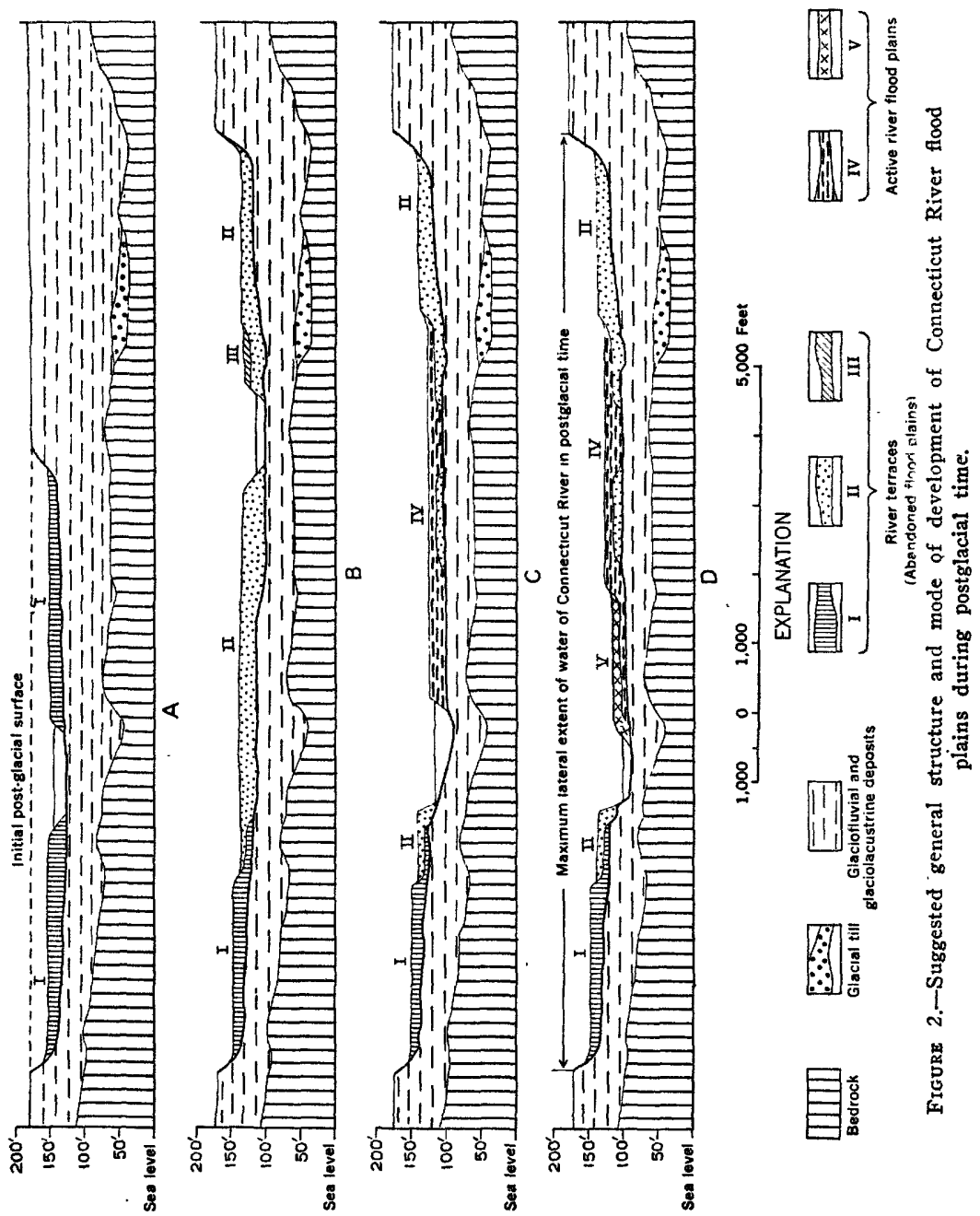

In section $C$ the river has completed the formation of flood plain III, and has entirely removed it to make way for flood plain IV. Benches I 
and II are now both terraces, although II may be within the reach of waters of occasional great floods. The nature of the contact of terrace and flood plain is largely hypothetical, inasmuch as good exposures of such critical sections are rare. Furthermore, an unconformity of this type is very difficult to recognize in any section composed of deposits laid down under the rapidly varying conditions of flood-plain sedimentation. In April 1940, however, a clear-cut exposure of a small isolated mass of older flood-plain material buried under much more recent river deposits was found in the low, freshly eroded east bank of the Connecticut I.5 miles south of Hadley, principally because the differences in materials involved permitted positive identification. The situation appears to be somewhat analogous to that shown near the center of section $\mathrm{C}$.

Section $D$ represents approximately the conditions as they now ext along the river. A new low flood plain (V) has been formed as a veneer over a scoured remnant of IV, which is on the point of abandonment as a true flood plain. Terrace III, which is actually widely preserved in the valley, is missing from this section. The river, which has been cutting downward into glacial sediments over large parts of each of the sections illustrated, here reveals a low exposure of these sediments on its left bank. Where this general situation actually occurs, the sediments thus exposed are commonly the varved clays of the glacial lake bottoms.

\section{IRREGULAR SURFACE FEATURES}

Surface irregularities on the river meadows are numerous. Elongated zones of scour, formed by strong overbank flobds, are conspicuous erosional forms. Individual scours tend to follow depressions between the scrolls of covered meander plains wherever possible, and consequently emphasize the crescentic pattern of those features. Old scours may be preserved on relatively high-level terraces, as for example on those south of Sunderland and in the vicinity of Bradstreet (Mount Toby quadrangle, pl. 5), and their presence may be attested by small streams, which follow them.

Natural levees, which rise locally as much as 6 or 8 feet above the plains behind them, are best developed along the straighter reaches of the river where the banks are fairly high. Those in the vicinity of Sunderland are fine examples. During many past floods these barriers have saved large areas from inundation.

The silts and sands of the glacial lake bottoms and Recent meadowlands have supplied material for the formation of many dunes. Most of those on river terraces are small; they are common along the eastern borders of the Northfield and Hadley-Hatfield Meadows. Larger and more numerous dunes lie near west-facing margins of the lake-bottom plains adjacent to the meadow areas just mentioned. 


\section{TERRACE AND FLOOD-PLAIN DISTRIBUTION}

NORTHFIELD MEADOWS

The Lily Pond terrace in the Northfield area owes its relatively wide original distribution to its great height, because it was formed well above many of the bedrock spurs that have restricted the lateral swing of the river during its later stages. The outer margin of this terrace is an unusually high scarp that marks the abandonment of the waterfalls over the Lily Pond "dam" near Turners Falls. Remnants of lower benches that correspond roughly in position to terrace II in downstream areas have been observed in only one place. Analogues of the lower terraces are common. It seems reasonable to assume, therefore, that the abandonment of the Lily Pond terrace occurred in middle or early Recent time, at least several thousand years ago, probably during the development of terrace II as a flood plain farther downstream.

Individual terrace and flood-plain areas are narrow and heavily scoured. Because of the constriction of the Northfield Meadows, many terraces give way to lower terraces on their downstream, rather than riverward edges. Because such boundaries are not well-defined scarps their exact delineation is more difficult here than in the broader meadows south of Sunderland. Benches corresponding to the low terrace (III) and the high flood plain (II) are most common.

\section{GORGE AREAS}

Tiny terrace and flood-plain remnants, which are preserved in favorable locations, are characteristic of the gorgelike portions of the present river. They have little significance in recent flood studies. An important exception, however, is a high terrace area half a mile or more in width on the east side-of the river south of Turners Falls. This evidently was formed by the early Recent Connecticut River at the expense of Lake Montague bottom deposits before it became superimposed on bedrock. This terrace has not been subject to floodwater inundation during historical time.

\section{OTHER MEADOW AREAS}

The distribution of the various terrace and flood-plain levels in the Hadley-Hatfield Meadows is unusual and has been largely responsible for the confinement of important recent flood damage to the southern, more densely settled parts of the area. Terraces are preserved almost to the exclusion of flood plains north of North Hadley, a condition that persists upstream throughout the Montague Meadows. The river has been incised into terrace III along most of this area and for hundreds of years has been forming natural levees, rather than lower-lying flood plains. (See pl. 5.) The situation is reversed in the Hadley-Northampton-Mount Tom Junction area, where the terraces are mere remnants as compared with the broad and continuous flood plains. Natural levees 
are virtually absent, and every few years floodwaters occupy rather large areas.

In the Springfield-Willimansett Meadows, flood plains and terraces that belong to all five general levels (see p. 34) are well developed and preserved. Terrace III occupies large parts of Springfield, West Springfield, and the densely settled area south of Willimansett, and presents dangers of inundation during the rare and exceptionally high floods. As in the Hadley-Hatfield Meadows, there is a tendency for most active flood plains to be confined to the southern portions of the area. Unlike the meadows in the vicinity of Mount Tom Junction to the north, however, the Agawam area in the southern part of the Springfield-Willimansett Meadows contains large remnants of high river terraces.

\section{TRIBUTARY TERRACES AND FLOOD PLAINS}

Narrow flood plains and terraces occur along the canyonlike upper and middle reaches of all tributary streams, but are not treated in this report. Extensive meadow areas are present, however, where large tributary streams traverse the valley floor before emptying into the Connecticut. Chief among these are the broad Deerfield Meadows and Westfield Meadows. (See pls. I and 3.) The Deerfield Meadows lie between narrow, high glacial terraces and are not visibly affected by bedrock spuirs at more than a few points, whereas the meadows along the Westfield, which have been studied in detail by Davis, ${ }^{38}$ traverse a region of very heterogeneous glacial deposits and, according to him, over a large area have been controlled by bedrock. Time did not permit a detailed study of the terraces and flood plains in these two tributary areas, although a few observations have suggested a possible correlation with the five general levels along the Connecticut River.

The Chicopee River has formed extensive terraces in a few places. (See pl. I.) Terraces along the Millers River are confined to the anomalous valley below Millers Falls. Smaller tributaries have their own sets of terraces and flood plains, most of which form veneers over wide erosion troughs cut either in glacial lake-bottom sediments or in deposits of the high Connecticut River terraces. On the other hand, low flood-plain sediments of the Connecticut River locally form veneers over older terrace deposits of tributaries, notably near the mouths of Russellville Brook, north of North Hadley, and Fort River, south of Hadley. (See p1. $6 A$.) The relatively great extent of meadow areas along the lower reaches of the smaller tributary streams appears to be the result of rapid cutting into the soft and nonresistant Quaternary materials.

as Davis, W. M., The terraces of the Westfield River, Mass.: Am. Jour. Sci., 4th ser., vol. 14, pp. 77-94, 1902.

$689520-47-4$ 


\section{CAUSES OF NORMAL RIVER-TERRACE DEVELOPMENT}

In general, the formation of river flood plains and their preservation as terraces during the orderly progress of a river's history may be attributed to one or more of the following causes:

1. Lowering of base level, either by crustal uplift af uniform magnitude over broad areas, by eustatic fall in sea level, or by a combination of both factors.

2. Differential crustal uplift, resulting in steepening of the river profile.

a. Constant or uniformly changing rate.

b. Pulsatory rate.

3. Preservation of individual flood-plain and terrace facets by bedrock spurs.

4. Broad climatic variations, causing variation in volume of the river, as well as in vegetation and soil cover of the drainage basin.

Apparently anomalous flood plains may be caused by:

1. Abandonment of one channel in favor of a bypassing lower one.

2. Stream capture.

3. Removal of a temporary base-level control, such as a lake or a resistant barrier or obstruction in the stream channel.

4. General addition or subtraction of stream load by natural or human agencies.

\section{CONNECTICUT RIVER TERRACES}

Among the causes of orderly stream terracing cited above, the first may be eliminated so far as the Massachusetts part of the Connecticut River is concerned, inasmuch as Recent crustal uplift in the drainage basin is known to have titled the land surface (see pp. 27-29). Further, the position of sea level has had no effect upon this part of the river during postglacial time because of the presence of rock barriers at Turners Falls, Holyoke, and Thompsonville. To permit sea level to exercise direct control over local base level upstream from a rock threshold, that threshold must lose its function as a barrier, either through drowning by marine waters or through complete destruction. Under present conditions in the lower part of the river headward erosion is slow, and has not succeeded in removing the first rock threshold in Connecticut. Consequently, the thresholds in Massachusetts have acted as independent local base-level controls throughout post-Pleistocene time.

Crustal tilt of this region since the disappearance of the ice sheets must have been an important, if not the chief cause for the Recent terracing along the Connecticut. It has been stated ${ }^{39}$ that the resultant lowering of base level progressed at a slow and fairly steady rate, a conclusion based mainly on the concept of an irregular vertical distribution of river-terrace and flood-plain levels in the valley. Such irregularity, however, does not appear to be entirely true in Massachusetts, as stated in an earlier connection. The general fivefold grouping of levels along the Connecticut may suggest, rather, a pulsatory lowering of base level, presumably the result of marked irregularities in the rate

s9 Davis, W. M., The terraces of the Westfield River, Mass.: Am. Jour. Sci., 4th ser., vol. 14, pp. 77-94, 1902. Flint, R. F., Late-Pleistocene sequence in the Connecticut Valley: Geol. Soc. America Bull., vol. 41, p. 983, 1933. 
of crustal tilt. The question is not one for detailed discussion in this report, but the suggestion is here made that a steady, uniform lowering of base level, and an implied similarly uniform rate of tilt, in the Massachusetts portion of the Connecticut Valley is a concept not entirely warranted by the facts as known.

The preservation of river-terrace remnants by bedrock spurs, a process first discussed by Miller, ${ }^{40}$ has been considered by Davis ${ }^{41}$ to be the principal explanation for the many small terrace facets at apparently random elevations in the valley of the Westfield River immediately west of Westfield. The bedrock spurs, which project into areas once occupied by the Recent Connecticut River and in a few places now occupy present river banks, demand further consideration of this process. Small terrace remnants at random elevations are exceedingly rare along the Connecticut. Preservation of such remnants by projecting rock ledges seems to have been a process of very minor importance, therefore, in the valley as a whole, chiefly because the necessary rock ledges are absent or rare in most areas of wide meadow development. Moreover, the outer boundaries of rock-flanked meadows along the Connecticut in Massachusetts do not show an areal pattern sufficiently cuspate to protect and preserve intermediate terrace facets. The part of the Westfield River described by Davis, therefore, is probably an area in the Connecticut Valley bottom that is almost uniquely favorable to such rock-defense processes, although they doubtless have been very active throughout the river valleys in the flanking highlands, where the bedrock consists mainly of crystalline types.

It is probable that broad climatic variations have occurred over western New England since the Pleistocene. Their effects upon the regimen of the Connecticut cannot be ignored, although it is almost impossible to estimate their relative magnitude. The evaluation of the various combinations of such effects and those of crustal tilt presents further complications. The net result of the various agents noted seems to have been a succession of local base levels that may have been falling with considerable irregularity of rate throughout post-Pleistocene time.

\section{MEANDERS AND OXBOWS}

The early Recent Connecticut River must have meandered to a considerably greater degree than its modern counterpart does. This is shown by the old crescentic scarps that mark the outer limits of its postglacial swinging in many places. Meandering was soon greatly curtailed in the Northfield and Montague Meadows, however, as the river encountered the ledges of rock in its down cutting and thus was restricted to a constantly narrowing belt of activity. A combination of bedrock spurs,

\footnotetext{
${ }^{40}$ Miller, Hugh, River terracing, its methods and their results: Proc. Royal Phys. Soc., pp. 263-305, 1883.

1 Davis, W. M., op. cit., pp. 77-94, 1902.
} 
till, and high-terrace deposits of the glacial sequence may have brought about the somewhat similar result in the Springfield-Willimansett Meadows. The scars of several large meanders are to be found on terrace edges in the vicinity of Agawam, but the meanders themselves were cut off many hundred or even several thousand years ago, and most traces of their oxbows have been obliterated.

The Hadley-Hatfield Meadows have supported by far the broadest meanders, one of which is preserved today as the great bend at Hadley. (See pls. I and 3.) After the draining of Lake Hadley, the Connecticut must have flowed in broad curves from Sunderland to Mount Tom Junction. As its meanders grew, were cut off, and formed again in new positions, there followed a gradual extinction, which progressed from north to south and straightened the river course accordingly. Meandering was long active south of Bradstreet, however, because of a deflection of the river by bedrock north of North Hadley (pl. 5), and even today the river follows a sharp bend before continuing southward. A very large oxbow, now partly occupied by Great Pond (Mount Toby quadrangle), and, two smaller more recent ones nearer the river are remnants of former meanders.

The history of the great. bend at Hadley (Mount Holyoke and Eastampton quadrangles) is more complex. It appears to have been formed as a normal meander during a period when the present low terrace (III) was still an active flood plain. Before river-bank erosion could proceed to the point where a normal cut-off was imminent, however, down cutting, presumably in response to base-level changes, had progressed so rapidly that the river had actually incised itself in its own flood plains. Bank erosion was retarded as a result, and much of the meander became essentially stable. Its present peculiar east-west elongation is due to subsequent bar and flood-plain accretion on the slip-off or lee slope west of Hadley and on a similarly situated part of the east edge of the Northampton Meadows.

The most remarkable oxbow series is that south of Northampton (Easthampton quadrangle); its development was responsible for the great width of the Hadley-Hatfield Meadows immediately north of the Mount Tom Range. (See pl. I.) A small, old oxbow is now occupied by Danks Pond and the lower end of the Manhan River northeast of Easthampton, and the western part of what may have been a very large meander is now occupied by Danks Swamp and Neds Ditch west of the Manhan Meadows. After the latter was cut off, the Connecticut formed one of its last great meanders, the neck of which ultimately became so narrow at Mount Tom Junction that the river broke through during flood stage in I840. ${ }^{42}$ A very perfect oxbow lake, still connected with the river at one cnd, marks this last abandoned segment of the river. (See pl. I.)

\footnotetext{
42 This flood, whose magnitude and activity were so great in the vicinity of Northampton, has not been included in previously published lists of Connecticut River floods, possibly because it was caused in part by ice jams and as such was essentially local in its effect.
} 


\section{FLOOD-PLAIN AND TERRACE DEPOSITS}

\section{BOTTOM AND BAR SANDS}

Complete terrace and flood-plain sections are well exposed in few places, nearly all of them along the banks of the Connecticut itself. Even in places where the river is actively cutting its banks a section must be visited soon after the high-water stage has passed, because it is quickly obscured by slump. This slump is largely due to the coarse, loose deposits of the bottom or bar sequence, which, where their bases are exposed, lie on eroded surfaces of varved clay or till, on bedrock, or, very rarely, on deposits of an earlier Recent river-terrace sequence. They represent the earliest deposits of a given terrace or flood-plain cycle. (See-accompanying sections of sediments.)

The base of a bottom and bar section usually consists of a 2 -inch to 3-foot zone of pebble or cobble gravel, commonly heavily stained or even cemented with iron oxides, more rarely with manganese oxides. Above the gravel lie medium to very coarse, well-bedded, moderately well sorted, locally micaceous sands with thin pebble beds. Iron staining in this part of the section is generally confined to a few thin beds. The dip is very gentle southward; where cross lamination occurs, the foresets lie in various attitudes but dip chiefly southward, moderately if the material is sand, much more steeply if the pebble content is large. This is a depsitional feature also noted in certain laboratory experiments. ${ }^{43}$ Topset beds are preserved only in the uppermost parts of the sequence, and show current ripple marks of large amplitude.

TABLE 5.-Section of sediments in low terrace (III), north edge of szirl-pit area, 1 mile north of Hatficld (Mount Toby quadranglc)

Flood deposits and subsequent eolian deposits :

Ft. in.

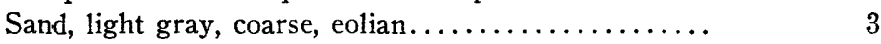

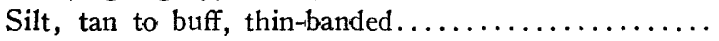

Upper flood-plain or loessiail sequence :

Soil, sandy, buff, with many living roots; capped with distinct sod zone..$\ldots \ldots \ldots \ldots \ldots \ldots \ldots \ldots \ldots \ldots \ldots$
Soil, dark gray, sandy, with many roots; grades fairly sharply but irregularly into material above and below

Silt, very fine, tan to dark gray, structureless; loessial

Silt, fine, sandy, gray to buff, spotted with small ironstained patches; very faintly bedded.............

Silt, fine, buff, alternating with $1 / 2$-inch beds of silt, gray, sandy $\ldots \ldots \ldots \ldots \ldots \ldots \ldots \ldots \ldots \ldots \ldots \ldots \ldots \ldots$

Total, upper flood-plain sequence..........

\begin{tabular}{ccc}
1 & 3 \\
& & \\
& 6 & 2 \\
& 7 \\
& 7 \\
& $10 \mathrm{~T} / 2$ \\
\hline 5 & $4 \mathrm{r} / 2$ \\
\hline
\end{tabular}

43 Nevin, C. M., and Trainer, D. W., Jr., Laboratory study in delta building: Geol. Soc. America Bull., vol. 38 , p. $453,1927$. 
TABLE 5.-Section of sedincnts in low terrace (III), north edgc of swirl-pit area, 1 mile north of Hatfield (Mount Toby quadrangle)-Continued

Lower flood-plain or "banded" sequence:

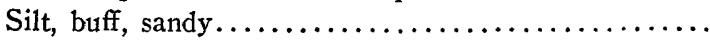

Sand, gray, medium to coarse, cross-laminated, lentic-

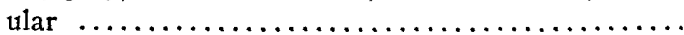

Silt, buff, sandy, alternating in 1 -inch beds. with sand,

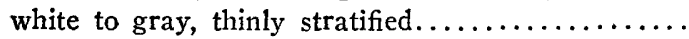

Sand, white, strongly cross-laminated.............

Silt, sandy, mottled brown, and silt, gray, sandy, alternating in thin beds; two thin clayey lentils near middle .................................

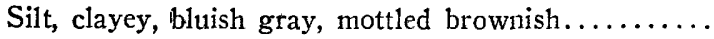

Sand, fine to coarse, white to gray, loose...........

Sand, fine, thin-bedded, ripple-marked; scoured and

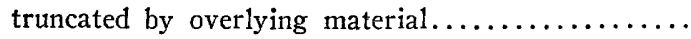

Silt, sandy, mottled, locally contorted..............

Sand, coarse, white, ripple-marked, iron-stained zone

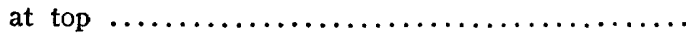

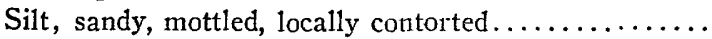

Sand, coarse, white, loose, alternating in $1 / 4$-inch beds with silt, buff, sandy....................

Sand, white, coarse, evenly bedded; strongly truncates

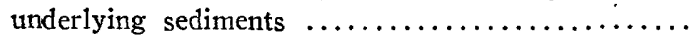

Silt, gray, sandy, poorly bedded, mottled brown; $1 / 2-$ inch blue clayey silt at base.................

Silt, bluish gray, clayey, mottled, and sand, $\tan$ to gray, mottled, alternating in $3 / 4$-inch to 1 -inch beds.

Total, lower flood-plain sequence.

Bar and bottom sequence:

Sand, coarse, light gray, blotched with brilliant red

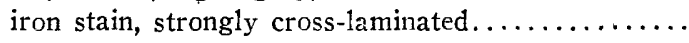

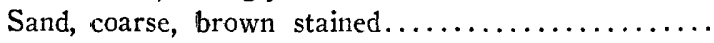

Sand, medium to coarse, light gray, lenticular........

Sand, coarse, stained and cemented to a black; hard mass by iron and manganese oxides..............

Sand, buff to brownish, fine to coarse.............

Sand, silty, pearl gray, locally much contorted, lenticular

Sand, very coarse, light gray, locally cross-laminated; stained and cemented near base................

Sand, medium to coarse, locally silty, strongly crosslaminated; local bluish-gray clayey bands.........

Sand, coarse, cross-laminated, and pebble gravel,

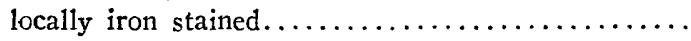

Total, bar and bottom sequence............

$5 \quad 4 \quad 4 / 2$

Glacial sequence:

Varved clay, bluish gray, with local thick laminae; poorly exposed, base not exposed.............. 
TABLE 6.-Section of sediments in intermediate terrace (II), east bank of Connecticut River, 1.6 miles northwest of Montague (71/2-minute Greenfield quadrangle)

Material derived from adjacent recent flood deposits :

Sand, white to gray, medium-grained, structureless;

probably eolian ...........................

${ }_{1}$ Upper flood-plain or loessial sequence:

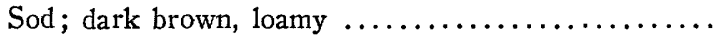

Soil ; loamy to sandy, buff to brown, structureless....

Silty loam; buff, structureless, mottled with small, irregular brownish spots; grades imperceptibly into material above and below; in part loessial; weathers into rectangular blocks

Silt, buff to tan, very fine, very faintly bedded.......

Silt, sandy, pinkish buff, alternating in $1 / 2$-inch faint beds with silt, very fine, buff; whole nearly struc-

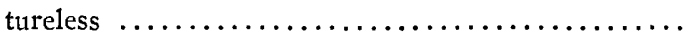

Silt, fine, buff, with many irregular patches of dark limonite stain; persistent zone.................

Silt, fine, tan to buff, mottled with bluish-gray and pinkish spots and patches; in part loessial; breaks into blocky masses .........................

Silt, sandy, tan, structureless; grades into finer material above

17

2

Silt, very fine, chocolate brown, in part loessial; very sticky when wet; bears local inclusions of sand, tan, medium to coarse, surrounded by aureoles of blue clayey silt; upper contact sharp and marked by

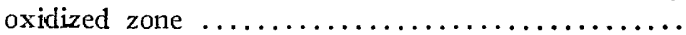

Upper flood-plain or loessial sequence-Contintied.

Silt, similar to material immediately above, but has 10 faint $1 / 2$-inch to $11 / 2$-inch beds of sandy silt.......

Total, upper flood-plain sequence...........

\begin{tabular}{ll}
1 & 3 \\
\hline 11 & 5 \\
\hline
\end{tabular}

Lower flood-plain or "banded" sequence:

Sand, light gray, coarse, in thin horizontal beds...... 6

Silt, chocolate brown, thin-bedded................

Sand, light to medium gray, in thin and horizontal

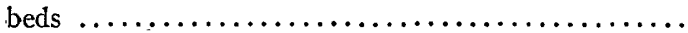

Silt, chocolate-brown to buff, alternating in 2 to 4 -inch beds with sand, medium to coarse, light gray, loose

Silt, sandy, greenish gray, thin-bedded; upper half with current ripple marks...................

Sand, very coarse, light gray, micaceous, horizontally bedded

Silt, dark gray to brown, sandy, alternating in $1 / 2$-inch to 1 -inch beds with sand, light gray, medium to coarse, horizontally bedded $\ldots \ldots \ldots \ldots \ldots \ldots \ldots$.

Sand, locally silty, gray to greenish brown, pseudo cross-laminated; well-defined current $r$ ipples

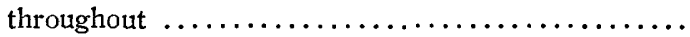

Silt, dark brown, sandy; forms resistant band on

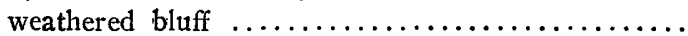


TABLE 6.-Section of sedinchts in intermediate terrace (II), east bank of Connecticut River, 1.6 miles northrest of Montague (7//2-minute Greenfield quadrangle) -Continued

Ft. in.

Sand, locally silty, light gray to brownish, in thin horizontal beds $\ldots \ldots \ldots \ldots \ldots \ldots \ldots \ldots \ldots \ldots$.

Total, lower flood-plain sequence..........

\begin{tabular}{ll}
1 & 6 \\
\hline 12 & $61 / 2$ \\
\hline
\end{tabular}

Bar and bottom sequence:

Sand, light gray, very coarse, local small pebble zones; generally horizontally bedded.............

Sand, light gray, pebbly, loose; finer beds gently foreset downstream; 6 -inch, coarse pebble beds foreset very steeply; typical bar bedding............

Gravel, pebbly, with thin interbeds of heavily ironstained sand; local irregular clots of manganese-

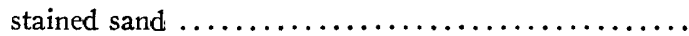

Gravel, pebbly to cobbly near base; heavily ironstained, especially near base $\ldots \ldots \ldots \ldots \ldots \ldots \ldots$

Total, bar and bottom sequence........... $2 \quad 2$

$3 \quad 111 / 2$

$1 \quad 10$

\begin{tabular}{ll}
3 & 2 \\
\hline 11 & $11 / 2$ \\
\hline
\end{tabular}

Glacial sequence :

Varved clay; bluish to greenish gray, silty, poorly exposed; top marked by horizon of strong springs

Total thickness of section, to river level (lowwater stage $) \ldots \ldots \ldots \ldots \ldots \ldots \ldots \ldots \ldots$

\section{LOWER FLOOD-PLAIN SEQUENCE}

The lower flood-plain, or "banded" sequence, consists of alternating beds of medium-to-coarse, loose sand and of compact sandy silt. This alternation gives rise to differential wind scour on freshly exposed river banks, so that a fluted or banded appearance results. (See section in pl. $6, B$.) The deposits of this sequence probably record the raising of the bar above normal river level as a low flood plain, with corresponding changes in sedimentation. The sands and silts are commonly ripplemarked, and many of the thicker beds show a pseudo cross lamination due almost entirely to lee-side concentration of garnet and magnetite during progressive downstream ripple movement (pl. 6,B.), a feaure of very common occurrence on the Colorado River delta. ${ }^{44}$ The lower flood-plain deposits pass into those characteristic of the upper flood-plain sequence by a gradual disappearance of the medium-to-coarse sand beds.

UPPER FLOOD-PLAIN SEQUENCE

The fine, sandy silts that form a thick, continuous veneer over each meadow area in the valley are representative of the upper flood-plain or loessial sequence. They constitute the meander-plain cover, and were

44 McKee, E. D., Some types of bedding in the Colorado River delta: Jour. Geol., vol. 47, p. $71,1939$. 


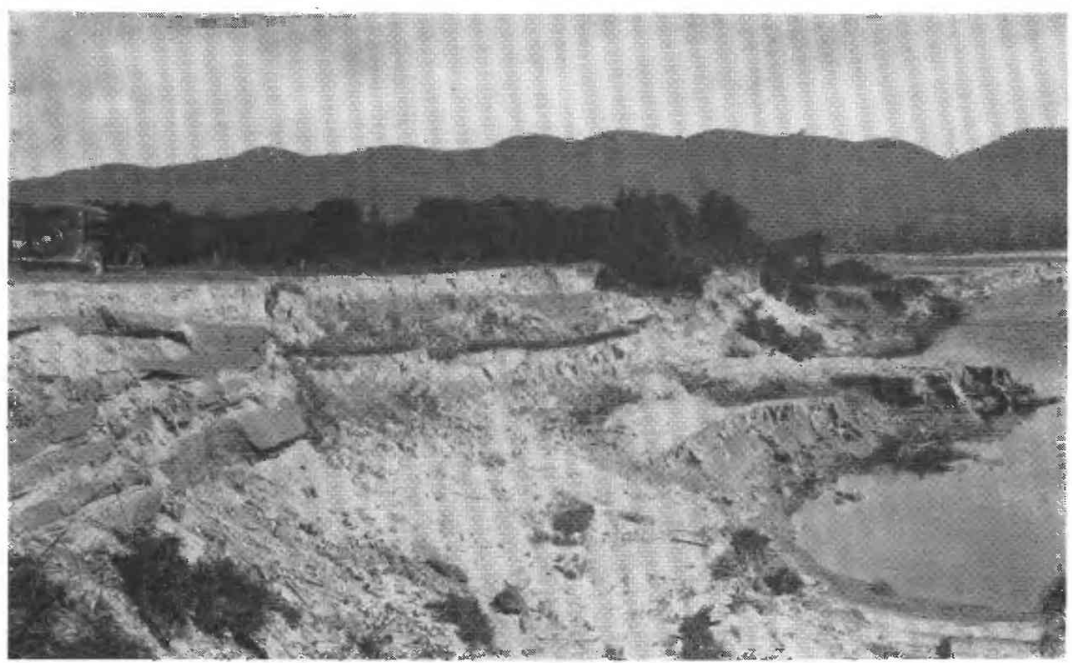

A. GENERAL VIEW SOITHEAST, WITH HOLYOKE RANGE IN BACKGROUND.

Low terrace (III) at left, Fort River terrace veneered with Connecticut River flood-plain deposits in distance at right. Note slump from terrace face. Low projection into river in right foreground is varved clay.

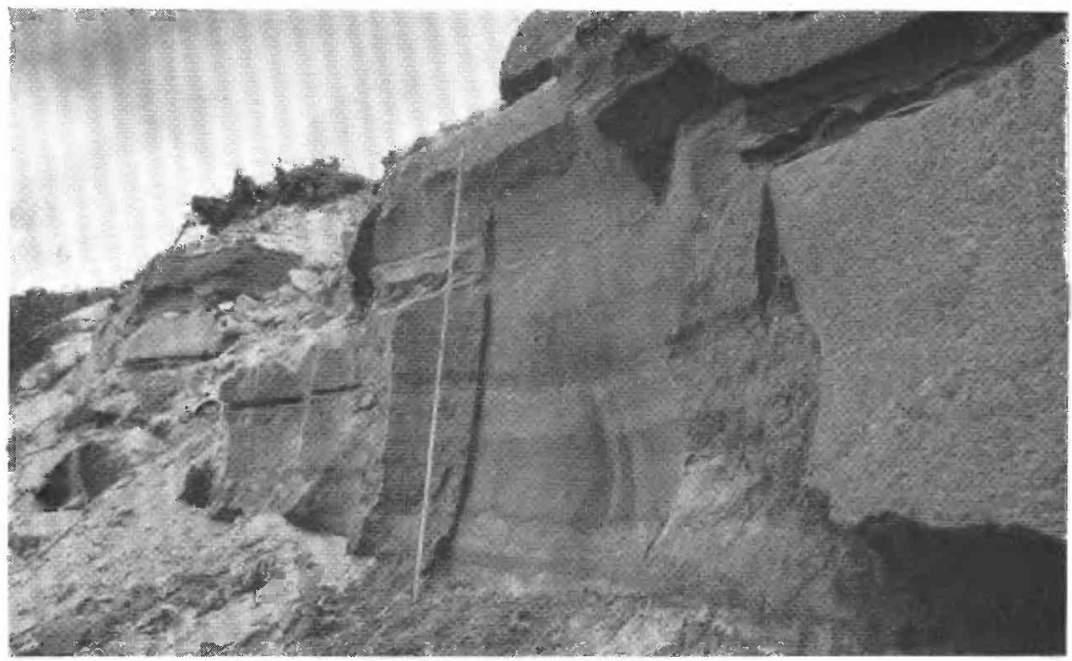

B. DETAIL OF LOWER FLOOD-PLAIN DEPOSITS, MERGING INTO BAR OR BOTTOM SANDS NEAR BASE OF FRESHLY TRIMMED AREA.

Note ripple mark and pseudo cross lamination.

EAST BANK OF CONNECTICUT RIVER 1 MLLE SOUTH OF HADLEY. 

termed water-formed river loess by Emerson, ${ }^{45}$ who pointed out their similarity to the Rhine loess. As shown in the foregoing sections, much of the basal portion consists of clearly and thinly stratified sandy silts, annual deposits of the river in a rather low flood-plain environment. These deposits pass gradually upward into material of the same general origin and texture, but whose structure has been entirely destroyed through reworking by roots, worms, burrowing mammals, wind, rain, frost, and ordinary slump. This massive, compact material is characteristically gray to buff or tan, and is mottled with small spots of iron stain, which may mark the positions of roots or of old worm burrows.

The relative thicknessess of the stratified and massive portions of the sequence vary greatly from one terrace or flood plain to another, or even from one place to another on the same terrace. Stratified sections containing more than 230 recognizable annual alternations have been observed in deposits of terrace III, for example, as contrasted with the very few present at a similar position in the foregoing section of terrace II. The massive deposits vary in thickness from 2 to 6 feet, and form vertical walls at the tops of actively eroded river bluffs. They are capped by a loamy soil, obviously derived from them.

Not all of the massive deposits are of the same general age, however. Most of those in any given terrace are the reworked products of ordinary over-bank flood deposition, which occurred when the terrace was a flood plain. Others, however, are of much later origin, though scarcely distinguishable from the underlying deposits, and were formed of material brought in during very late Recent time by the wind and, locally, by exceedingly high floods, as well as of material derived from the underlying loess through cultivation, slump, or similar processes. They appear as a continuous layer, 6 inches to 2 feet thick, which caps all terraces and terrace scarps and which merges into the most recent river deposits at the tops of the present flood plains.

\section{RECENT FLOOD DEPOSITION}

The depositional processes active along the river today must be much like those responsible for the accumulation of the materials that make up each present terrace section. Bars and low islands are being formed and raised by the addition of gravel and coarse sand. Some have been incorporated with low flood plains as sandy beaches. As these beaches are built up to certain general levels, they are veneered with flat beds of finer. material, the thickness and coarseness of which depend largely upon the height of a given bar or beach during flood stages of the river. The higher flood plains are now developing their cover of structureless, in part loessial material. The great dust storms in the valley

45 Emerson, B. K., Geology of old Hampshire County, Mass.: U. S. Geol. Survey Mon. 29 , p. $729,1898$. 
after every serious flood doubtless provide the mechanism for much of this deposition.

The deposition of sediments by the recent excessively high floods was very unusual in several respects. Low flood plains were covered to such great depths by flood waters that they received coarse deposits normally characteristic of beaches and bars. The high flood plains were left with typical low flood-plain deposits, and terraces that had not been inundated for hundreds of years were thinly veneered with silty and sandy material. Floods of this magnitude form remarkable chapters in the depositional history of any river, and a more detailed discussion of their characteristics, as well as those of their deposits is given farther on.

\section{SUMMARY OF CONNECTICUT RIVER TERRACES AND FLOOD PLAINS}

That part of the valley in Massachusetts occupied by the Connecticut River during postglacial time is characterized by terraces and flood plains that apparently can be grouped into five general levels. An anomalous river terrace is present upstream from Turners Falls, and represents a flood plain formed when the river was held at a much higher level by a rock barrier. Its course across this rock barrier was abandoned at least several thousand years ago because a much lower.gap was then uncovered. The normal terraces and flood plains slope very gently away from the river and are bordered on their inner margins by distinct scarps that in many places are the scars of old meanders. Most of the benches appear to have been formed as meander plains, whose low and subdued scrolls are still visible in spite of a later cover of typical flood-plain. deposits. Elongated areas of scour and even the courses of small brooks commonly emphasize this scroll pattern.

The terrace and flood-plain areas, or "meadows," are narrow in the Northfield and Montague Meadows, partly because of lateral control by bedrock. They are broadly developed in the Hadley-Hatfield and Springfield-Willimansett Meadows, with the lower terraces and flood plains dominant in the southern portion of each area but virtually absent from the northern portions. Wide meadow areas are present along the lower courses of certain tributary streams, and seem to have many characteristics similar to those of the Connecticut. The terracing along all the streams probably was the result of lowered base levels, caused by postglacial southward crustal tilt, and possibly in part also the result of broad climatic variations over the drainage basin. A few terrace facets at random elevations owe their preservation to nearby protective bedrock spurs.

Meanders appear to have been characteristic of the early Recent Connecticut, but subsequently have become fewer and fewer in number. Over most of the broad meadow areas the river has a fairly straight course protected by natural levees, but great oxbows, some of them still bearing 
ponds or lakes, attest the recent presence of meanders in the central and southern parts of the Hadley-Hatfield Meadows. The great bend at Hadley is the only meander since 1840 , when the river broke through the neck of the large meander immediately north of the Mount Tom Range.

Each terrace is composed of materials that demonstrate its progressive passage through the stages of river bottom, river bars, beaches, low flood plain, and high flood plain. In general the sediments become coarser from the top to the bottom of any complete section. The flood-plain deposits in a given terrace are capped by structureless, compact material derived through working over by plants and animals, as well as by wind, rain, and frost. The present flood-plain sections are an incomplete series, inasmuch as they represent various intermediate stages in the terrace cycle.

\section{CHARACTERISTICS OF THE CONNECTICUT RIVER AND ITS TRIBUTARIES}

\section{CONNECTICUT RIVER}

The Connecticut River is about 390 miles long and has a drainage basin area of II,320 square miles above its mouth. Comparisons with other rivers are made in table 7 . Consideration of its path through Massachusetts, however, suggests that some of its general characteristics are most unusual. Its profile, for example, shows the presence of the three important bedrock thresholds in and adjacent to its Massachusetts portion. (See pl. 7.) The sharp breaks occur at Thompsonville, Conn. (A), Holyoke, Mass. (B), and Turners Falls, Mass. (C). Upstream from each rock barrier lies a wide meadow area of very low river gradient.

Plate 7 shows the profiles of other well-known rivers in the United States for comparison. Both the Potomac and the Roanoke have breaks near the lower ends of their profiles; these breaks, however, represent the Fall Line, upstream from which each of the rivers flows with appreciable gradient through a relatively narrow valley. That part of the Hudson immediately upstream from Troy and Albany flows in a fairly wide valley, but with much steeper gradient than is characteristic of corresponding parts of the Connecticut. The Sacramento and Ouachita Rivers are both streams of very low gradient along their lower courses; neither has a rock barrier similar to any of those along the lower Connecticut. 
TABLE 7.-Comparison of certain major rivers of the United States

\begin{tabular}{|c|c|c|c|}
\hline & $\begin{array}{l}\text { Total length } \\
\text { (miles) }\end{array}$ & $\underset{\text { (square }}{\text { Basin }}$ & $\begin{array}{l}\text { area } \\
\text { miles) }\end{array}$ \\
\hline Merrimack................ & 186 & & 5,015 \\
\hline Willamette................................... & 269 & & 11,200 \\
\hline 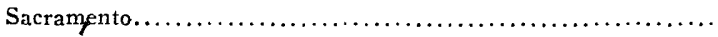 & 380 & & 27,100 \\
\hline Potomac............... & 383 & & 14,500 \\
\hline Connecticut............... & 392 & & 11,320 \\
\hline Roanoke............................ & 400 & & 9,630 \\
\hline 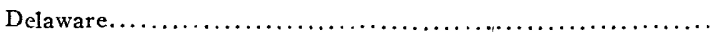 & 412 & & 12,765 \\
\hline 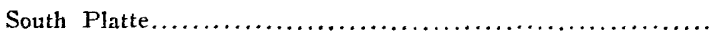 & 450 & & 24,080 \\
\hline Ouachita...$\ldots \ldots \ldots \ldots \ldots \ldots \ldots$ & 605 & & 24,790 \\
\hline Tennessee................. & 652 & & 40,600 \\
\hline Yellowstone............... & 670 & & 70,400 \\
\hline Platte.......... & 760 & & 90,200 \\
\hline 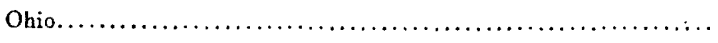 & 981 & & 204,000 \\
\hline Snake................... & 1,036 & & 109,000 \\
\hline Columbia.... & 1,210 & $\cdot$ & 259,000 \\
\hline Red............................... & 1,300 & & 66,640 \\
\hline Arkansas........................... & 1,450 & & 160,500 \\
\hline Missouri............................... & 2,470 . & & 529,000 \\
\hline
\end{tabular}

1 Data in part from Corps of Engineers, U. S. Army.

The Willamette River in Oregon is perhaps the most nearly comparable stream. It flows through the broad, alluviated lower Willamette Valley and is graded to a bedrock threshold at Oregon City, near its junction with the Columbia. The Merrimac flows over a similar barrier at Lowell, but the valley upstream from this point is relatively small. Most of the other, larger streams have low gradients in their broad-valley reaches, but are controlled by sea level, rather than by rock barriers; where rock does form the beds of these rivers, it is much more continuous than in the typically short barriers. The profile of the Ohio is entirely different from that of the Connecticut, and that of the lower reaches of the Columbia above tide water is more like the New Hampshire and Vermont portions of the Connecticut.

The presence of bedrock thresholds, backed by broad-valley, low-gradient reaches, seems to be characteristic of few rivers in the United States. This is scarcely surprising, because the thresholds along the lower Connecticut are the results of local river diversion through glacial interference. It serves to emphasize, however, the need for careful scrutiny of a river and its surrounding country before generalizations are made concerning its flood behavior and flood-plain activities. 


\section{CHANNEL CHARACTERISTICS}

Like the channels of nearly all rivers, that of the Connecticut is a succession of irregularly spaced and shaped shallows and deeps. The most prominent shallows are of course the bedrock riffles of the three thresholds. Immediately downstream from any bedrock baffle, the channel bottom is commonly deeply scoured, and this is followed downstream in turn by broad gravel bars. Similar bars encroach upon the channel from the slip-off or lee slopes of strong bends; in such places a corresponding deep forms on the opposite or outer part of the bend. Other channel obstructions tend to accumulate near the mouths of tributaries, where the current is retarded, and at places where it is deflected by dams, bridge abutments, or other man-made works. Bar formation has been very rapid, as in the vicinity of Hockanum (Mount Holyoke quadrangle), which marks the effective upstream limit of the ponding influence of the Holyoke Dam. The Westfield River also has laid down a large gravel fan in the Connecticut opposite Springfield:

Although the position of the deeper part of the channel is fairly stable wherever it impinges laterally on bedrock, elsewhere it shifts very rapid$1 \mathrm{y}$, as shown by successive river surveys, by reports of long-time residents of the area, and even by observations over periods of a few years. Many statements have been made concerning the presence of bars or islands in positions once occupied by the deepest parts of the channel. If the testimony of several old-time rivermen is to be accepted, the channel in the Hadley-Hatfield Meadows as a whole has shallowed considerably during the past few decades. Boats that drew 4 feet of water are said to have plied between Smiths Ferry and Sunderland in midsummer 50 years ago; now in summer the river is less than a foot deep over its entire width at many points along the same stretch. The exact cause for this shallowing is not known, but it may be due entirely to the reestablishment of a normally shallow channel after a temporarily deeper one had been formed by headward erosion in response to the slight increase in gradient supplied by the cut-off of the Mount Tom meander in I840.

\section{LATERAL ChANNEL CONTROL}

It already has been stated that the present channel of the Connecticut is restricted laterally by bedrock at one or more points in every division of the river valley. So far as further movement toward such rock buttresses is concerned, the channel may be considered essentially stable. The only other parts of the river channel that are laterally stable are the nearly straight areas where flood plains are absent. The river banks are the edges of terraces 28 feet or more above mean river level, and they are protected along most of their extent by well-developed natural levees. That part of the river between Sunderland and the sharp bend north of North Hadley shows complete development of these characteristics. In contrast, the river in the southern part of the Hadley-Hatfield Meadows 
follows the great Hadley bend during ordinary high water, but overtops its banks and flows across the high flood plain during extreme stages.

The more mobile parts of the river channel are in contact laterally with a variety of deposits. Where the river has encountered till, as for example near Northampton and south of Agawam, its lateral cutting has been considerably slower; where glacial lake-bottom deposits or river flood-plain deposits are encountered, lateral cutting is generally much more rapid. It is correspondingly slower where the river impinges on higher-level deltaic deposits of the glacial sequence.

Of considerable importance to the regimen of the present river has been the common practice among farmers of developing "made" land at the expense of the river channel by judicious control of tree growth along its banks. According to the statements of several old inhabitants of the North Hadley, Russellville, and Sunderland areas, local strips of land amounting to fifty yards or more in width have been made in this manner during the past two centuries. This practice has been popular in the Springfield-Willimansett Meadows north of the Westfield River mouth. The effect of such channel constriction has been to cause a slight rise in flood-water levels, although any exact measure of the rise is impossible.

\section{PRINCIPAL TRIBUTARIES}

As the large tributary streams issue from the highland areas, they undergo a sudden flattening of profile and a broadening of their valley bottoms. This decrease in gradient favors the formation of cones, fans, and bars. Some streams, like the Sawmill River, are braided for a mile or more from their point of entry into the relatively flat bottom of the Connecticut Valley. The Westfield, Millers, and Deerfield Rivers have developed braided, unstable high-water channels along corresponding parts of their courses, and the Deerfield has one small active bypass near Stillwater Bridge (Shelburne Falls and $7^{\mathrm{T} / 2^{\prime}}$ Greenfield quadrangles). Normal terraces and flood plains flank the rivers downstream from these depositional areas of coarse material.

\section{FLOOD-INUNDATION CYCLE}

The steplike arrangement of the river meadows in the Connecticut Valley and their fivefold vertical grouping make it possible to determine, within certain limits, the relative magnitudes of floods by a comparison of the extent of the areas inundated. Such comparison is unnecessary so far as the discharge values along the river are concerned, because they have been calculated by other methods, which are mathematically more reliable. ${ }^{46}$ A correlation between serious floods of known magnitude and the extent of areas inundated by each is important, however, because

46 Grover, N. C., and others, The floods of March, 1936; Part 1. New England rivers: U. S. Geol. Survey Water-Supply Paper 798, pp. 70-86, 1937. 
it furnishes a clear basis for comparing the erosive and depositional activities of different floods at different places in the flood-plain areas. It also demonstrates the remarkable extent of the geological work done by catastrophic floods as compared with that done by the river during the usual high-water stages, which cause inundation of the low flood plain (V) nearly every spring. For example, the concept of a single flood rising high enough to cover terrace surfaces long abandoned as active flood plains is one much neglected in past geologic studies of the work of rivers. Finally, the mere mapping of terrace and flood-plain boundaries in the Connecticut Valley affords opportunity for the correlation of flood discharge with inundation, for the prediction of characteristics of flow and flooding, and for recognition of most points of possible danger in future floods.

\section{HYPOTHETICAL EXAM̈PL}

Plate 8 illustrates, in a series of block diagrams, a somewhat idealized portion of the Connecticut Valley about 2 miles wide. Some vertical exaggeration has been necessary. Two terraces of glacial origin (G1), lie on the left. Adjacent to them are intermediate and low terraces (II and III) of the postglacial Connecticut River. The high flood plain (IV) appears on both sides of the river; into it on the left side has been cut a low flood-plain facet (V). Some of the scarps, such as that along the inner edge of terrace II, are probably meander scars. A natural levee (n1) and a dune (du) are also shown. The entire series is traversed by two small tributary streams (tr), into one of which flows a secondary tributary $\left(\operatorname{tr}^{\prime}\right)$. Succeeding blocks show the same area in certain flood stages, each of which refers to the flood of March 1936, during which occurred the greatest recorded inundation in the Connecticut Valley. The relations are not necessarily true of the entire valley, but are closely representative of most areas in it.

\section{LOW-WATER CONDITION}

The condition of low water, illustrated in plate $8, A$, is characteristic of the Connecticut during much of the summer and fall seasons. Flood plain IV forms high banks at the river edge, and even the banks of the lower flood plain, V, rise about I 5 feet above water level. The tributaries join the river as flowing streams at or near its banks. The Connecticut itself is sluggish and fairly shallow, though its rather straight course shown on the diagram is not conducive to the development of bars.

\section{HIGH-WATER CONDITION}

Plate $8, B$ shows the high-water condition that is reached by the Connecticut almost every spring, and in some years two or three times during the spring. It may represent also an incipient flood stage, because such high water usually indicates that throughout the drainage basin available 
moisture storage in the zone of aeration is fully utilized and that succeeding heavy precipitation may result in floods because of lack of natural storage.

The diagram shows the river swollen to characteristic high-water proportions. The low flood plain (V) is completely inundated by shallow water and the high flood plain (IV) stands only 5 or 6 feet above river level. The waters of the Connecticut have occupied the lower parts of the tributary valleys; the tributaries themselves empty into these temporarily ponded areas. Similar backwaters have occupied an old, partially filled oxbow, most of which lies outside the diagram toward the observer, and have extended to a point (ox) in the center foreground.

\section{RISING FLOOD CONDITION}

Plate 8,C, represents the rising condition of the flood of March 1936, but it is equalled or slightly exceeded by the crests of all other floods in the valley only 12 to 16 times in a century. The high flood plain (IV) is partly inundated, with only the natural levees and other low eminences projecting from the waters, which are probably actively scouring the surfaces between them and the scarp of terrace III. The flood waters are also encroaching much farther up the tributary valleys than before.

Floods at this general stage are very destructive to crop lands and to towns in the lower meadow areas. The floods like that of November I927, which seem to occur from three to four times in a century, ${ }^{47}$ reach heights slightly greater than that here shown. They completely cover the high flood plain (IV) to its inner margin, and rise several feet on the scarp of the low terrace. The damage they cause is correspondingly great. The flood of September 1938, only slightly lower than the great flood of March 1936, rose over the scarp of terrace III.

\section{PEAK FLOOD CONDITION}

Plate $8, D$, shows conditions at and near the peak reached by the March 1936 flood, which was unique among recorded floods of the Connecticut. In this diagram all flood plains are completely covered, as is most of the low terrace (III) and small parts of the intermediate terrace (II). Far greater volumes of water are required to raise the flood level an inch on the scarp of terrace III than to accomplish the same result at a lower stage on the scarp of flood plain IV. The unique extent of the March I 936 flood, as illustrated by the difference between C and D, is therefore truly remarkable. During the peak stage (D), the Connecticnt is shown overlying broad meadow areas as a vast lake, but strong currents are active. Considerable directed scour is in progress in favorable places, and the river accomplishes much general erosion and deposition. The flood waters in September 1938 acted similarly, but at their peak they covered

\footnotetext{
${ }^{47}$ Kinnison, H. B., The New England flood of November 1927: U. S. Geol. Survey WaterSupply Paper 636, pp. 87.90, 1930.
} 
parts of the low terrace (III) and did not reach terrace II. Both floods were exceedingly destructive over wide areas.

\section{FALLING FLOOD CONDITION}

So far as the flood-water level is concerned, the falling condition is exactly the equivalent of the rising condition. Plate $8, E$, however, shows certain effects of peak-condition flood waters on the low terrace (III). Strong, elongated scour zones, somewhat exaggerated in the diagram, have been developed. The positions of some of them are controlled by the scroll distribution on the terrace, but others owe their positions to the presence of nearby dunes, natural levees, or other surface irregularities. Similar scours probably would appear on the high flood-plain surface (IV) after the flood waters receded from it. The waters backed up into the tributary valleys slowly recede toward the river, and the tributaries soon resume their own activity in their lowermost courses.

\section{GENERAL FEATURES OF THE 1936 AND 1938 FLOODS FLOOD OF MARCH 1936}

\section{METEOROLOGIC CONDITIONS}

The extraordinary floods that occurred over New England in March I936 were preceded by an unusual combination of weather conditions, among which were two general storms during the periods March 9-13 and March I6-I9. Detailed analyses of the meteorological phenomena incident to the flood have been made by Lichtblau ${ }^{48}$ and others, ${ }^{49}$ and the general conditions are well described in the summary report ${ }^{50}$ on the New England floods. Briefly, very cold weather in the early winter had frozen the ground to at least normal depth, after which unusually heavy snowfalls occurred in January and February. The weather remained very cold until early mid-March, when unseasonably high temperatures and the extraordinary rainfall of the two storms combined to create the heavy runoff in the drainage basin.

\section{NATURE OF THE FLOOD}

The storm of March 9-13, together with the train of meteorological events that preceded it in Vermont, New Hampshire, and northern Massachusetts, served to create serious flood conditions along the Connecticut River beginning on March I2. (See pl. 9.) These conditions were considerably aggravated by the accompanying break-up of an unusually heavy ice cover, which had formed during the prolonged periods

\footnotetext{
${ }^{48}$ Lichtblau, Stephen, Weather associated with the floods of March 1936, in Grover, N. C., and others, The floods of March 1936; part 3, Potomac, James, and upper Ohio Rivers: U. S. Geol. Survey Water-Supply Paper 800, pp. 12-31, 1927.

¿ See bibliography, under section on meteorology and hydrology of New England floods.

${ }^{50}$ Grover, N. C., and others, The floods of March 1936, part 1, New England rivers: U. S. Geol. Survey Water-Supply Paper 798, pp. 12-14, 1937.

$689520-47-5$
} 
of very low temperatures in January and February. This first, or "ice" flood reached a stage where its waters covered much of the high floodplain area in the valley (See IV, pl. 8.) Although it rose to a distinct peak (pl. 9) and was the result of a distinct storm, it may be treated as a rising condition of the river (fig. 8,C) with respect to the greater flood that followed it. The causes and hydrologic behavior of both floods were closely related, and they overlapped considerably in their discharges. ${ }^{51}$

The second and more severe storm of March I6-I9 contributed so much additional water to the already swollen and overburdened streams that river stages began a rapid and spectacular rise on March I8. The record-breaking peaks were reached within 2 days, as shown on plate 9 . The peaks at Vernon, Turner Falls, and Holyoke were markedly flattened, probably because of storage action in the reservoir behind the dam at each of these cities. The Hartford "split peak" has been explained ${ }^{52}$ as the result of overtopping and partial destruction of the Colt and Clark Dikes there on March 20, followed by rapid flood-water occupancy of the large storage area behind the dikes.

The crest of the flood discharge passed from White River Junction to Turners Falls, a distance of 92 miles, in approximately 16 hours, and thus travelled at an average rate of nearly 6 miles per hour. The 70 miles between Turners Falls and Hartford were traversed in I4 hours, or at an average rate of 5 miles per hour. This downstream decrease in rate of crest travel may have been due in part to the corresponding decrease in river gradient. Of the principal tributaries in Massachusetts, those on the west side of the valley conributed discharge peaks a day or more earlier than those on the east side, which coincided in time with the Connecticut River peak. The Westfield and Deerfield Rivers were falling rapidly at the time when the discharge crest of the Connecticut was passing their mouths. These features may represent distinctions inherent in the types of runoff from those parts of the Berkshire Hills and central uplands that lie within the Connecticut drainage basin.

After the flood crest passed, the Connecticut River entered upon a falling water condition ( $\mathrm{pl}, 8, E$ ) which continued for a period of 8 or 9 days. On March 29, the river began a more rapid fall to a typical highwater level, which it maintained for 2 weeks or more. Thus the characteristics of the Connecticut River before, during, and after the two floods of March 1936 took the form of the clearly defined states shown in plate 8.

\section{FLOODED AREAS}

The waters of the Connecticut spread extensively during their peak stages in March 1936. Plate Io shows the flooded areas, the Lily Pond

\footnotetext{
51 Grover, N. C., and others, op. cit., pp. 374-375, 1937.

82 Kinnison, H. B., Conover, L. F., and Bigwood, B. L., Stages and flood discharges of the Connecticut River at Hartford, Conn.: U. S. Geol. Survey Water-Supply Paper 836-A, p. $14,1938$.
} 
terrace, and parts of meadow areas that were not flooded. With few exceptions, these last are remnants of terraces I and II. Table 8 indicates the relative dimensions of certain land forms in the valley and demonstrates a feature of considerable importance, namely, that during the great flood of March 1936, the Connecticut River waters reoccupied 38.0 square miles, or four-fiths of the entire area in which the river has been active since glacial time. This unusual amount was due mainly to the reoccupancy of most of terrace III, which, except for the high flood plain, is the most extensive meadow level in the valley.

TABLE 8.-Relative ('xtent of floodreater inundation in the Massachusetts part of the Connecticut Valley, March 1936

Valley bottom, total area .................... square miles.. 353

Water bodies within valley bottom, total area at normal level ................................... 12

Terraces and flood plains of Connecticut and lower Deerfield and Westfield Rivers, total

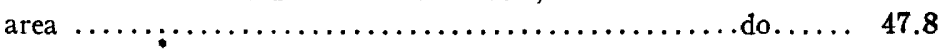

Terrace and flood-plain areas inundated by floodwaters, March 1936 . do...... 38

Relative amount of total river-terrace and floodplain areas inundated...$\ldots \ldots \ldots \ldots \ldots \ldots \ldots \ldots$ percent....

Relative amount of total valley-bottom area inundated do......

The profile of the flood crest, as constructed from published data, ${ }^{5 s}$ is shown in plate $I 6$ in comparison with lowest water levels of the river. It is evident that at its lowest-water stage the river, with a gradient of only 3 or 4 inches per mile in the meadow areas, accomplishes little work other than a slight shifting of bars in its channel. Much the same condition exists during mean-water stage, because, as before, nearly the entire fall through the state occurs at the two rock gorges, now occupied by dams. Juring high flood stages, however, conditions are materially changed. An increased total drop from one State boundary to the other, combined with an appreciable decrease in fall through the gorges causes a very marked increase in gradient throughout the meadow areas. This meadow gradient reaches 12 to $I 7$ inches per mile during especially severe floods and enables the water to accomplish nearly catastrophic physiographic changes.

In March, 1936, the entire Northfield Meadows area, including the fertile Pauchaug Meadow, Moose Plain, Great Meadow, Bennetts Meadow, Little Meadow, and Pine Meadow (Northfield quadrangle), was covered by flood waters. Conditions appear to have been considerably ag-

\footnotetext{
63 Grover, N. C., and others, op. cit., pp. 419-420, 1937. Massachusetts Geodetic Survey, High water data, floods of March 1936 and September 1938 in Massachusetts, pp. 27-35, Massachusetts Dept. Pub. Works, Boston, 1939.
} 
gravated by the barrier effect of the French King Narrows, situated immediately north of the mouth of the Millers River. (See pl. I6 and Millers Falls quadrangle.) Plate ${ }_{4}, C$ shows part of this inundation during the falling stage of the flood. The normal channel is indicated by the positions of bridges and by lines of trees that grow on the banks.

In contrast, the river in the Turners Falls Gorge was widened but slightly; the narrowness of the inundated low terrace resulted in similar confinement of the flood waters in the Montague Meadows. As they issued onto the Hadley-Hatfield Meadows, however, the flood waters spread out rapidly over the broad low-terrace areas north of Hatfield and North Hadley. (See pl. Io and Mount Toby quadrangle.) After passing a slight constriction between bedrock ridges opposite Mount Warner, they spread again to form the broadest area of flooding in the valley. Near-crest conditions in the vicinity of Hadley are shown in plates I $3, A$ and II, $A$. Plate II, $B$ is a generalized physiographic map of the area shown in plate II, $A$, and it shows that most of the low terrace (III) between Hadley and the Fort River escaped flooding. This may be attributed to the falling of the flood crest owing to the spread of the waters south of Sunderland (pls. Io and I6), and to the fact that the Holyoke Narrows could carry off the waters more efficiently than the French King Narrows below the. Northfield Meadows. Plate I4, $A$ shows the normal appearance of the meadow area southwest of Hockanum (Mount Holyoke quadrangle), looking toward Mount Tom Iunction, as compared with its appearance (B) during the flood. The low meadows are flood-plain areas, and a terrace remnant lies in the foreground.

As in the Turners Falls Gorge, the river was widened only slightly through the Holyoke Narrows. It widened again, however, in the Springfield-Willimansett Meadows, south of the Holyoke Narrows.' The Springdale Dike on the west side of the river opposite Willimansett was overtopped and a small but thickly settled portion of Holyoke was flooded. The much more extensive area between Willimansett and Chicopee (Springfield North quadrangle) was also flooded, and hundreds of people were driven from their homes. The waters covered the broad meadows opposite Chicopee, the northwestern and central parts of Springfield (including much of the business district), and nearly all of West Springfield. Large meadow areas between Agawam and Longmeadow were also flooded, in places to considerable depths. As in the Hadley-Hatfield Meadows, flood waters extended over both flood plains and most of the low terrace.

The lower reaches of the four great tributaries were also extensively flooded. The large Deerfield Meadows were almost entirely covered; part of the village of Deerfield was the only important area spared. (See pl. 10.) The Westfield Meadows were similarly affected. The Chicopee 
River, because of its narrow lower valley, spread far beyond its banks only in the broad meadows east of Chicopee Falls. The Millers River was almost ponded in its gravel-choked lower valley because of the bedrock narrows at its mouth.

\section{GENERAL DAMAGE}

The activities of the first flood (or rising condition of the "great flood" if both floods are treated as a unit) were normal as to discharge values in all parts of the valley in Massachusetts except in the southern end of the Hadley-Hatfield Meadows. This area was affected by a tightly packed ice jam that formed on March I3 at a point near Mount Tom Junction, $6 \mathrm{r} / 2$ miles upstream from Holyoke, and soon extended itself northward for a considerable distance. Nearly the entire flow of the swollen river was diverted across the inner part of the Hockanum Meadows, where it threatened to establish a new channel. This diverted stream returned to its normal channel near Mount Tom Junction, however, when the huge ice barrier broke during the evening of March I5, floated downstream at a rate of more than 6 miles per hour, and passed over the Holyoke dam at a stage of 9.5 feet above the crest. ${ }^{54}$ The battering of the great ice blocks is thought to have removed 5 to 8 feet of the granite crest of the dam for over three-fourths of its 1,020 -foot length. As soon as the normal channel was rid of the ice jam, it was reoccupied by the main current of the swollen river.

Most of the damage to agricultural land was done by local deep scour, strong river-bank corrasion, which was at some places accompanied by removal of many tons of material, and deposition elsewhere of appreciable thicknesses of rather coarse sediment. A tremendous amount of damage was done in thickly settled areas by the battering of large objects carried by the flood waters, by deposition of silt in and around huildings, and by the wetting of their interiors.

The Schell and Bennetts Meadow Bridges in the Northfield Meadows withstood a severe pounding by the river and by the ice blocks, barns, trees, and other objects that floated on its surface, although the Schell Bridge might have failed had not the main flood current passed by its western end. Three of the four spans of the Central Vermont Railway bridge (pl. $4, C)$ were carried away at 6:30 p.m., March I8, when the river stood more than a foot above the lower members of its trusses.

An abandoned steel trolley bridge at Montague City was destroyed on March I8, at $2: 10$ p.m. Not long afterward the nearby highway bridge, well known as the largest covered bridge of the broad-arch type in Massachusetts, yielded and failed, although it had withstood a long. continued battering during the flood of 1927. Two of its wooden spans floated downstream past the mouth of the Deerfield River and tore away two of the three steel spans of the New Haven Railroad bridge. It is

4 Grover, N. C., and others. The floods of March 1936, part 1, New England Rivers: U. S. Geol. Survey Water-Supply Paper 798, p. 17, 1937. 
said that one of the wooden spans later passed the heavy steel Boston and Maine Railroad bridge at East Deerfield ( $7^{1 / 2}$ minute Greenfield quadrangle) by being sucked completely under it.

The light steel highway bridge at Sunderland failed shortly after noon on March 18 . The old nine-span bridge of the Boston and Maine Railroad between Hadley and Northampton successfully resisted destruction because of its unusually high clearance, although many of its lower members were bent. The highway and trolley bridges immediately downstream, however, were badly damaged and battered out of alignment. The South Hadley Falls bridge below the dam at Holyoke was moved out of alignment; the terrific battering that it received from ice blocks, trees, houses, and other large objects was augmented by the effective hammering of great quantities of pulp wood torn from storage in the oxbow near Mount Tom Junction. Though seriously damaged, it was not destroyed.

The highway bridge at Willimansett escaped much injury because it was protected by the Boston and Maine Railroad bridge immediately upstream. This railroad bridge, a solid deck girder type, was loaded with gondola cars filled with scrap iron and gravel to resist the tremendous upward pressure of the flood. waters, which are said to have been more than a foot higher on the upstream than on the downstream side. Below Willimansett the river lost much of its velocity and became almost like a pool. The bridges near Springfield were much less seriously clamaged, on the whole, than those upstream.

Bridges, dams, and buildings along the Deerfield and Westfield Rivers received relatively slight damage, although a considerable amount of small-scale repair work was necessary. Conditions were different along the Millers River, however, where such structures were damaged or destroyed. Factory buildings and bridges were wrecked by ice where the river was forced into a constricted course through Athol and Orange, and similar serious consequences of artificial channel contraction were common downstream. Most of the damage to bridges and buildings along the Chicopee, River in Ludlow, Indian Orchard, Chicopee Falls, and Chicopee may be ascribed to serious encroachment on the normal river channel by dams, bridge abutments, and other structures.

\section{FLOOD OF SEPTEMBER 1938}

\section{METEOROLOGIC CONDITIONS}

The "hurricane flood" of 1938 occurred at a time nearly coincident with the passing of a hurricane over New England on September 2I, but was caused in large part by conditions not closely connected with that great storm. ${ }^{55}$ Most of the precipitation responsible for the flood

\footnotetext{
55 Paulsen, C. G., and others, The hurricane floods of September 1938: U. S. Geol. Survey Water-Supply Paper 867, pp. 8-34, 1940.
} 
seems to have been associated with a continental disturbance that centered over the Great Lakes region, and followed an earlier storm that contributed $\mathrm{I}$ to 4 inches of precipitation to the drainage basin during the period September 12-16. Thus the basin area was saturated with moisture when the major continental disturbance reached it on September I7. Precipitation became very heavy on September 21, when this "low" united with the hurricane "low," and it ceased abruptly after the hurricane passed. Of the total storm precipitation, which was heaviest over central Massachusetts, it is estimated that 3 inches was due solely to the hurricane. ${ }^{56}$ More detailed accounts of meterological conditions during this period are listed in the bibliography, section on meteorology and hydrology of New England floods. (See pp. I47-I48.)

\section{NATURE OF THE FLOOD}

The first storm of September I2-16 caused swelling of most streams in the drainage basin, but no serious high-water conditions along the Connecticut. The much heavier precipitation of the second storm, however, was quickly converted into heavy runoff. The Connecticut River rose very rapidly on September 20 and 21 , reached its peak in Massachusetts on September 22, and receded to stages only slightly above normal almost as quickly as it had risen. (See pl. 15.) Along the main stream, therefore, the general conditions during the critical portion of September $193^{8}$ were as follows: normal water, peak, falling, normal water. The rising condition was of such short duration that it cannot be considered a distinct feature as compared with that of the 1936 flood.

Although the hurricane flood along the Connecticut in Massachusetts reached discharge rates and heights second only to those of the March 1936 flood so far as all recorded floods are concerned, conditions were most severe along the tributary streams. Flood peaks were reached very rapidly, and the waters poured down the narrow canyons with devastating effect. Extraordinary discharges that exceeded all of those previously, recorded characterized the flow of the Millers, Chicopee, Deerfield, and Westfield Rivers.

\section{FLOODED AREAS}

The broadly flooded areas may be most simply described through a comparison with the areas flooded in March, 1936. As shown in plate I6, the crest profile was from 8 to Io feet below that of the 1936 flood in the Northfield Meadows. In spite of this difference, only the inner half of Moose Plain and a small part of Pine Meadow escaped flooding. In the Hadley-Hatfield Meadows, where the difference in crest heights was considerably less, the low terraces between Sunderland and North Hadley were thinly and only partly covered by waters. The broad flood plains

${ }^{50} \mathrm{Kimball}, \mathrm{J} . \mathrm{H}$. , The history and developments of the Long Island hurricane of September 21, 1938; report in manuscript form prepared for Power Group, New York Sec., Am. Inst. Elec. Eng., Dec. 6, 1938 , 
west of Hadley and south and east of Northampton, on the other hand, were completely covered. The crests in the Springfield-Willimansett Meadows were so nearly of the same height that the hurricane flood occupied essentially the same areas as did the flood of March, 1936, with the exception of small parts of Willimansett and a part of the business district of Springfield.

\section{GENERAL DAMAGE}

For most of the people who reside or own property in areas covered by the 1936 flood, the results of the huricane flood were an unpleasant repetition of those of its immediate predecessor, but the appalling list of damaged and destroyed bridges along the Connecticut was not duplicated. Structures that replaced those ruined in 1936 were designed and built to withstand future floods of like magnitude, and those that stood through the greater flood were so repaired and strengthened that they suffered little damage in 1938 .

Results were different along the large tributary streams. Waters of the Millers River, for example, severely damaged or totally destroyed factories; dams, highway and railroad bridges, and various artificial embankments, particularly at Millers Falls, Farley, Erving, Erving Mills, Wendell Depot, and Orange. (See Millers Falls and Orange quadrangles.) Factory buildings in Orange and Athol were broken into and their lower floors gutted by the flood waters. The Deerfield River and its tributaries were almost as destructive. Many small highway and railroad bridges, as well as dams and power plants, were greatly damaged or ruined, particularly between Shelburne Falls and Zoar. (See Hawley quadrangle.) $\cdot$

The Chicopee River destroyed the dam and power plant at Bircham Bend, and bridges at Chicopee Falls and Indian Orchard (Springfield

North quadrangle). Factory buildings were also severely damaged in those two cities, and in Chicopee, Ludlow, Thorndike, and Ware. The Davitt Memorial Bridge in Chicopee, a reinforced concrete-arch structure, was almost overtopped by the flood waters. (See pl. 3I.) At Woronoco the Westfield River rose over the northeast abutment of a large dam and cut through a thick mass of glacial drift to bedrock, making a deep new channel on the east side of the canyon. Considerable damage was done to bridges and other structures upstream, particularly at Russell and Crescent Mills, as well as far downstream in the city of Westfield.

\section{COMPARISON OF GREAT FLOODS}

The discharge and gage-height characteristics of the great flood of . 1936 and the hurricane flood of 1938 were strikingly different, even though their crest levels were nearly equal. (See pl. I6.) As shown in plate I5, the crest of the great flood was preceded and succeeded by stages of serious flood nature, whereas that of the hurricane flood rose and subsided very rapidly. The 1936 flood, although of extraordinary mag- 


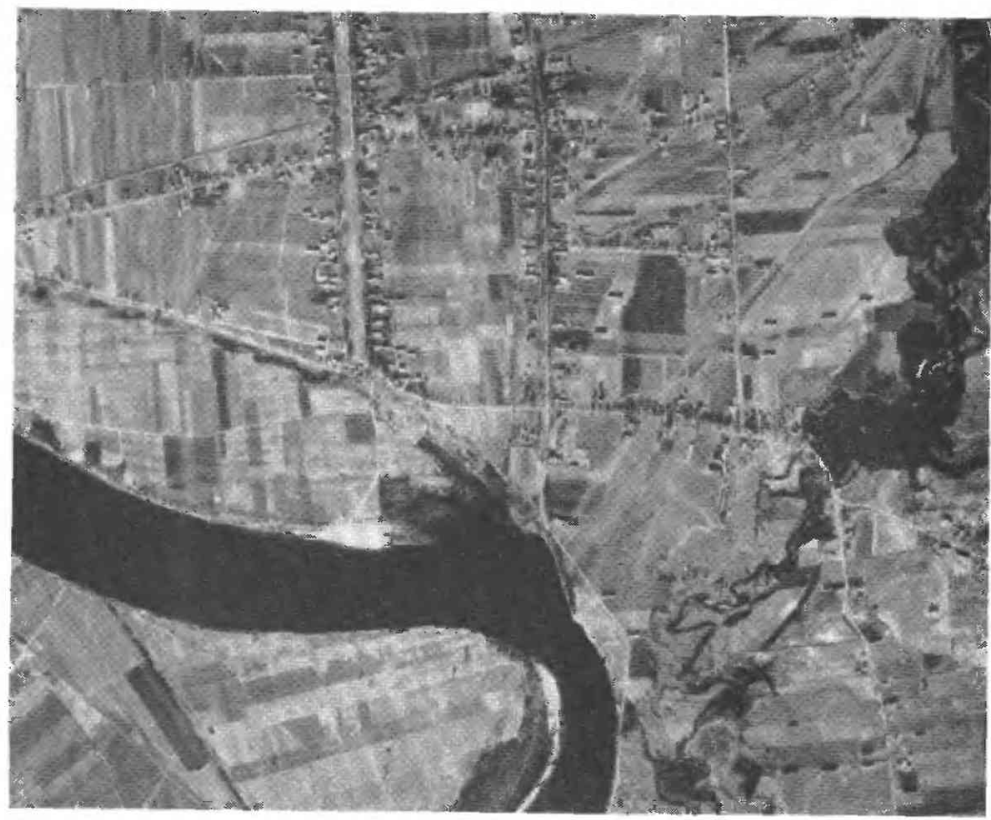

A. CONNECTICUTT AND FORT RIVERS IN HADLEY AREA AT NORMAL WINTER LOW-WATER STAGE.

Connecticut River on left; Fort River and Old Mill Pond on right; Hadley at center, top. Photograph courtesy of Fairchild Aerial Surveys, Inc.
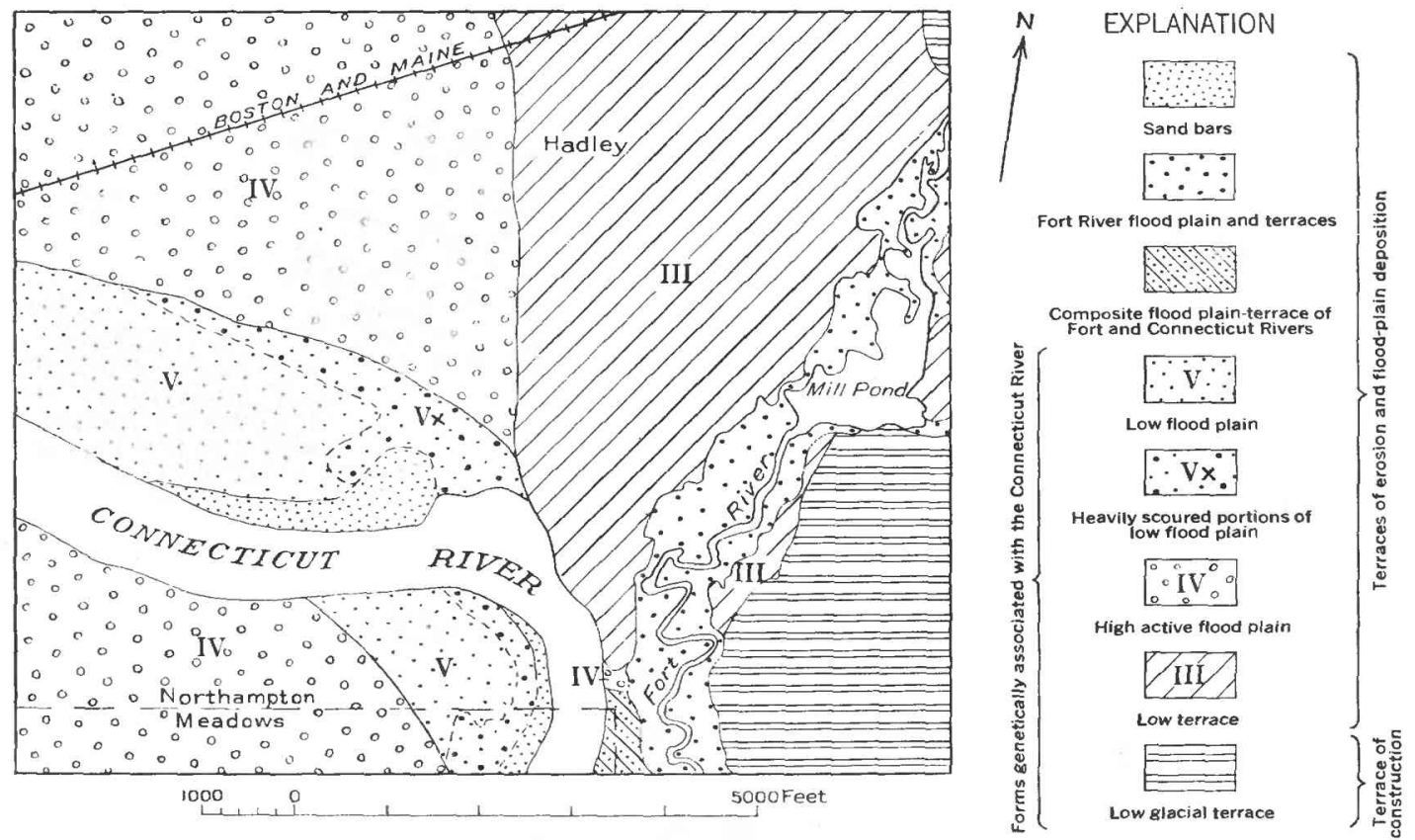

B. GENERALIZED MAP OF QUATERYARY LA ND FORMS IN THE HADLEY AREA. 
nitude, was relatively most serious along the main river. The hurricane flood, though of short duration as a great flood along the Connecticut, was of record-breaking intensity on many tributary streams, particularly those draining the central upland area of Massachusetts.

Data for the flood of November 1927 are given in table 9, which includes the crest stages of five great New England floods at selected points in the Connecticut drainage basin. Like the hurricane flood, that of 1927 was relatively most severe on tributary rivers, especially those in central and northern Vermont and in the White Mountain region of New Hampshire, where all existing discharge records were broken. The record stage established on the Connecticut at White River Junction was doubtless due to the tremendous discharge of the White River, which drains a large area in central Vermont. The 1927, 1936, and 1938 floods hold nearly every known discharge and crest-height record in the Connecticut River drainage basin. Prior to 1927 , most of the record peaks had been established by the floods of May I854 and April I862, data for which are included in the table. For the most complete existing list of floods along the lower Connecticut, together with peak values for each, the reader is referred to the summary paper by Kinnison, Conover, and Bigwood. ${ }^{57}$

TABLE 9.-Comparative crest stages of great floods at selected points in the Connecticut River drainage basin

\begin{tabular}{|c|c|c|c|c|c|c|}
\hline \multirow{2}{*}{ River } & \multirow{2}{*}{ Gaging station } & \multicolumn{5}{|c|}{ Gage height, in feet, for flood of- } \\
\hline & & $\begin{array}{l}\text { May } \\
1854\end{array}$ & $\begin{array}{l}\text { Apr. } \\
1862\end{array}$ & $\begin{array}{l}\text { Nov. } \\
1927\end{array}$ & $\begin{array}{l}\text { Mar. } \\
1936\end{array}$ & $\begin{array}{l}\text { Sept. } \\
1938\end{array}$ \\
\hline $\begin{array}{l}\text { Connecticut } \\
\text { Connecticut } \\
\text { Connecticut } \\
\text { Connecticut } \\
\text { Connecticut } \\
\text { Connecticut } \\
\text { White } \\
\text { Millers } \\
\text { Deerfield } \\
\\
\text { Chicopee } \\
\text { Westfield }\end{array}$ & 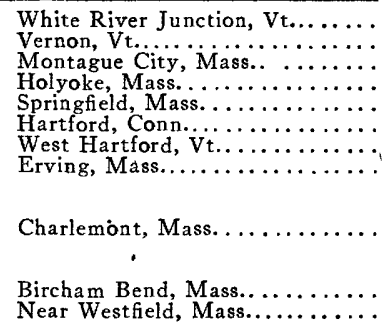 & $\begin{array}{l}\ldots \ldots \\
\ldots \ldots \\
10.5 \\
22.3 \\
529.8 \\
\cdots \cdots \\
\cdots \cdots\end{array}$ & $\begin{array}{l}\ldots \ldots \\
\cdots \cdots \\
12.5 \\
22.2 \\
28.7 \\
\cdots \cdots \\
\cdots \cdots\end{array}$ & $\begin{array}{c}135.0 \\
124.9 \\
342.7 \\
414.8 \\
422.4 \\
29.0 \\
229.3 \\
{ }^{6} \mathrm{Less} \\
\text { than } \\
4.95 \\
\text { 'Less } \\
\text { than } \\
5.98 \\
\text { 625.4 }\end{array}$ & $\begin{array}{r}32.6 \\
1128.8 \\
149.2 \\
116.8 \\
128.6 \\
137.6 \\
18.9 \\
10.9 \\
\\
14.2 \\
119.9 \\
19.9 \\
27.2\end{array}$ & $\begin{array}{r}26.7 \\
120.7 \\
44.7 \\
14.9 \\
25.8 \\
35.4 \\
19.3 \\
113.4 \\
\\
{ }_{120.2} \\
\\
{ }^{10}{ }_{129.4}\end{array}$ \\
\hline $\begin{array}{l}1 \text { Maximu } \\
2 \text { Maximu } \\
3 \text { Maximu } \\
4 \text { Maximu } \\
5 \text { Maximu } \\
6 \text { Maximu } \\
7 \text { Exceede } \\
8 \text { Flow at } \\
9 \text { Maximu } \\
10 \text { Gage de }\end{array}$ & $\begin{array}{l}\text { orded stage for station. } \\
\text { own stage to } 1936 . \\
\text { ge for period } 1904-35 \text {. } \\
\text { own stage for period } 1801-1935 \text {. } \\
\text { own stage for period } 1639-1935 \text {. } \\
\text { ge for period } 1915-35 \text {. } \\
\text { east once during } 1914-35 \text {. } \\
\text { lemont affected by storage in upst } \\
\text { ge height, affected by ice ja m; oth } \\
\text { ed during flood. }\end{array}$ & $\begin{array}{l}\text { ap } \\
\text { alu }\end{array}$ & $\begin{array}{l}f \mathrm{dr} \\
\text { eser }\end{array}$ & basi & . & \\
\hline
\end{tabular}

${ }^{57}$ Kinnison, H. B., Conover, L. F., and Bigwood, B. L., Stages and flood discharges of the Connecticut River at Hartford, Conn.: U. S. Geol. Survey Water-Supply Paper 836-A, 1938. 


\section{EROSIONAL EFFECTS OF THE 1936 AND 1938 FLOODS} UPLAND AREAS

\section{SLIDES AND GUL.I.IES}

The upland areas of central western Massachusetts, with their widespread cloak of vegetation, are susceptible to little gullying or to other processes of accelerated erosion. However, the rapid runoff of extraordinary volumes of water during the storms of March I936 and September I938 locally destroyed the relatively stable condition of the surface cover. It is not surprising that the areas so affected were small; nevertheless, their presence in the uplands and their very recent origin are both noteworthy.

The steep rock walls of many of the larger and deeper river gorges in the Berkshire Hills have a thin but fairly continuous cover of till, soil, and heavy vegetation. The bond between these surficial materials and the underlying glaciated bedrock probably never has been very secure, as is shown by the long-continued downward creep of the soils. This creep is generally so slow that in most places vegetation is able to grow uninterruptedly, but during periods of torrential runoff the bonding of the soil is further weakened by lubrication of its individual particles; the creep rate is thus tremendously increased locally and landslides may form. Many recent landslides, most of them rather small, were observed in canyons of the Deerfield and Westfield Rivers and in the lower tributaries of the Millers River, but were most common in the upper Deerfield in the vicinity of Zoar and on the west wall of Pulpit Rock Ridge (Hawley quadrangle). At the last-mentioned locality the narrow triangular scars of five very large recent slides extend 500 to 700 feet up the slope; they resemble similar features in the White Mountains of New Hampshire, another region of occasional excessively heavy precipitation.

Where farm lands are under cultivation, gully development does not appear to be a serious problem; where they are abandoned, the surface cover is stabilized through rapid growth of vegetation. Gullying occurs chiefly on steep, till-covered pasture slopes where the sod cover has been cut by small rills, which apparently started to erode along stock paths. The gullies formed from these rills are rarely deeper than 2 or 3 feet, because fresh till is commonly encountered at this depth and is apparently very resistant. According to the statements of farmers, old gullies were rapidly enlarged and new ones formed during periods of heavy storm runoff in the past few years, although such action has not been sufficiently great to constitute an acute problem in the region.

Improved secondary roads are favorable places for the development of small gullies. Erosion is most severe on slopes immediately above cuts and immediately below culverts, and in drainage ditches along roads where the grades are heavy. Many unimproved roads in the more sparsely 
settled portions of the upland areas, particularly those leading to abandoned farm houses, are severely gullied to depths of 2 feet or more, but these gullies are ultimately stabilized by vegetation.

\section{CHANNEL AND FLOOD-PLAIN EROSION}

It is generally recognized that tributary rivers in central western Massachusetts have severe floods several times a century. The conditions along such tributaries during and after floods have been well stated $^{58}$ as follows:

Immediately after such torrential runoff the surface conditions are favorable to recurring floods as the result of less severe storms. The high moisture content of the soil when winter sets in, the torn and gullied condition of the ground, which - favors rapid drainage, and the raw banks partly undercut by the meandering streams in surcharged channels, where great masses of earth and rock waste are seemingly poised ready to slough off when the spring thaw begins, all contribute to the higher stages and destructiveness of the next floods. The heavy burden of stones and gravel in motion along the stream beds, besides retarding the normal velocity and thereby causing overflow, adds greatly to the dynamic power of the flood for battering obstructions. At each widened section or reduction of slope a temporary rock-fill dam or bar is formed, around which the streams make wide detours by eroding the less resistant valley soil; and thus new chapters are begun in the record.

Conditions similar to those just outlined governed the four large tributaries in Massachusetts during the flood of March I936, but the breaking ice furnished additional battering rams of tremendous power. However, these floods appear merely to have set the stage for the devastating, record-breaking runoff of September 1938. Broad gravel fans and deltas, built out into the main streams by their tributaries during 1936 , did much to increase the height, lateral erosive power, and general destructiveness of the flood waters in 1938. Excellent examples of these features are to be found along the Deerfield River (Hawley quadrangle) at the mouths of Cold, Chickley, and Wilder Rivers and of Pelham, Mill, Avery, and Clesson Brooks. They doubtless will influence future floods in much the same manner, because they are re-formed during the end stages of each flood. Shoals and bars, as well as local jetties of coarse gravel and stone which are constructed for flood control, have similar undesirable effects during extraordinary floods.

The waters of the hurricane flood, laden with cobbles, boulders, and wreckage from structures upstream, rose over the normal river banks and spread destruction over the narrow flood-plain and low terrace areas. This was true at many places along the Westfield below Russell, where the river scoured steep-sided auxiliary channels, battered down or even sheared off entire groves of trees, and formed heavy, high-level gravel bars in the deepest parts of its former low-water channel. In many places the waters cut across the river bends and took a straight course

s Clark, G. G., McNary, J. V., and Jarvis, C. S., New England floods and highways, in Kinnison, H. B., The New England flood of November, 1927: U. S. Geol. Survey WaterSupply Paper 636, p, 100, 1930. 
down the valley. Where these bends were very sharp and bounded on their outer edges by high, resistant banks, the waters shot with great force across the flats on their inner sides, in a manner somewhat analogous to that noted on a much smaller scale in New York by Cole. ${ }^{59}$ The best example seen is the sharp bend on the Westfield River immediately north of Turtle Bend Mountain (Woronoco quadrangle). Where the normal channels are confined between high walls, most of the floodwater energy was expended in strong lateral corrasion, especially of glacial materials and artificial fills along the outer margins of bends. Such action caused the destruction of much of the State highway along the Cold River (Hawley quadrangle) and the damage to railroad embankments along the Deerfield, Millers, and Westfield Rivers.

\section{CHANNEL DIVERSION}

Large-scale channel diversions are rare in the upland areas because the valleys are narrow. Those of recent occurrence have been associated with poorly located or poorly protected dams, and are therefore due to interference with the normal activities of the rivers. The Westfield River flooded a low terrace at Woronoco, bypassed a dam at its northeast end, and quickly cut a wide gorge through approximately 60 feet of glacial drift to bedrock; it was later artificially restored to its normal channel. The Chicopee River rose over a similar terrace, destroyed a powerhouse and established the course it now occupies at Bircham Bend; the waters damaged the dam and then bypassed it to the south. Similar channel shifts were narrowly escaped on the Deerfield above Shelburne Falls, -on a tributary to the Ware River at Thorndyke, and at several other dams along the Chicopee.

\section{CONNEĊTICUT VALLEY}

\section{GULLY EROSION}

The best examples of Recent gully erosion in the valley bottom of the Connecticut are the small, rather straight, $\mathrm{V}$-shaped notches formed on the outer, oversteepened edges of glacial and postglacial terraces and flood plains. These developed rapidly in the soft terrace sediments. They vary in size and gradient according to the height of the scarp, its age, and the sandiness of the materials present in it. Most gullies or ravines in scarps of Pleistocene age, as well as those occupied by perennial brooks in younger scarps now have'normal parabolic profiles, and are developing further as small stream valleys. Many of the small, normally dry gullies in scarps of Recent age, however, are still working headward at a very rapid rate; their growth has notably increased in response to recent heavy precipitation and floods.

50 Cole, "W. S., Modification of incised, meanders by floods: Jour. Geol., vol. 45, pp. 648654, 1937. 
Those gullies developed on Recent scarps cut in till are of the parallel or faintly branching rill type, and are small. Those on glacial terraces are much larger and their heads are less steep and covered with vegetation. ${ }^{60}$ The profiles of some gullies in sediments of glacial lake bottoms show knick points where they pass from the sands and silts to the underlying, more resistant varved clays. The very recent sheet and gully erosion noted on the surfaces of glacial terraces in Connecticut by Bennett ${ }^{61}$ has been active in Massachusetts also, but apparently on a much smaller scale. This may be due in part to the greater extent of very flat, low-lying lake-bottom plains in Massachusetts, as well as to the high silt content of the deposits underlying the plains.

The shapes of gullies formed on the edges of river terraces or flood plains are affected by the resistance to erosion of the materials in which they are cut. The largest gullies in the meadow areas are represented on the newer topographic maps of the region. Many others have been formed since these maps were surveyed, especially in deeply scoured areas north of Hatfield, northwest of Hadley, and north of Northfield, most of which were formed in I936. The recent gullies that started on the edges of such depressions are rapidly enlarged by the waters of any later flood high enough to cover the meadows into which they are cutting. The deposits left on the surfaces of meadows by very large floods are particularly susceptible to rill erosion during periods of heavy rain, but none of the material is transported far; hence rill formation on the cultivated flood plains appears to have little serious consequence.

Another interesting type of gully is found on some of the till-covered ridges and hills in the valley. The best example is the lower course of a small intermittent brook on the north slope of Taylor Hill, o.9 mile westnorthwest of Montague. (See $7^{1 / 2}-$-minute Greenfield quadrangle.) The grassy bottom of the steep valley has been trenched by a large, irregular gully 8 feet deep. (See pl, I7,A.) This gully, which locally cuts to bedrock, heads at a road crossing halfway up the hill and empties onto an alluvial fan in a basinlike area $I, 500$ feet to the north. According to farmers who reside nearby, the gully was started in March 1936, presumably by a combination of heavy precipation and rapid thawing of the ground.

\section{FLOOD-PLAIN SCOUR}

A survey of all river terraces and flood plains in the valley has shown that recent deep scour was confined to areas where unusual volumes of rapid flood water flowed in March I936. Near Northfield the Connecticut River had a high east bank, which it could neither overtop nor rapidly erode, and floating debris piled up behind the Schell Bridge. These

\footnotetext{
${ }^{60}$ For gully classification, see Ireland, H. A., Sharpe, C. F. S., and Eargle, D. H., Principles of gully erosion in the Piedmont of South Carolina: U. S. Dept. Agriculture, Tech. Bull. 633, pp. 43-58, 1939.

61 Bennett, H. H., A permanent loss to New England: soil erosion resulting from the hurricane: Geog. Rev., vol. 29, pp. 196-204, 1939.
} 
conditions caused the scouring of a channel I,500 feet long, 400 feet wide, and more than 20 feet deep across the eastern corner of Moose Plain. (See Northfield quadrangle and pl. 4,C.) This channel is now occupied by the river as a bypass during its high-water stages. A similar, slightly smaller scour-channel was cut across a point of meadow land on the inner margin of a sharp bend immediately north of Munns Ferry. (See Northfield quadrangle.) At the outer margin of this bend is a high exposure of granitic gneiss, which forced the main current over a part of the meadow on the oposite side of the river during the peak stage of the flood.

In the area north of North Hadley (Mount Toby quadrangle), the main part of the current bent sharply to the west and encountered waters moving southward over the low terrace in the vicinity of Bradstreet. As a result, the flood waters crowded into the old oxbow now occupied by Great Pond and by Cow Bridge Brook and were trapped in its southern end. They broke through a low ridge at a point I.I miles north of Hatfield, and discharged southeastward through the constricted opening with tremendous volume and force. Large swirl pits were cut by these waters in the soft sediments of the meadow across which they flowed to rejoin the main channel of the river. Before the flood had subsided, many of the swirl pits had coalesced to form deeply scoured areas several acres in extent and of sufficient depth to expose the varved clays that underlie the old flood-plain sediments. An excellent detailed description of these interesting features has been published. ${ }^{62}$

The only other important area of heavy scour lies on the high flood plain (IV) about a half a mile northwest of Hadley. The river broke through a low dike built to protect the meadowlands between the two flanks of the great Hadley bend, and inundated the entire area west of State Highway 63. (See Mt. Holyoke quadrangle.) The ploughed fields south of the dike were scoured to depths of 15 feet or more (pl. 13,B), but a large cemetery, protected by an iron fence and by its sod cover, was left almost isolated in a broad scour basin.

Scours were shallow and restricted to relatively small areas where the flood-water velocities were not excessive. Most of them formed along previous loci of erosion, commonly interscroll depressions, particularly in the Hadley-Hatfield and Springfield-Willimansett Meadows. Several were formed along minor roads, where no protective grass cover was present, and still others were very, local features formed by eddies around houses, barns, posts, trees, and other rigid obstructions.

The sod cover of many areas resisted erosion to a striking degree. Grassed flood plains were not eroded even when they were covered by flood waters that flowed swiftly enough to deposit debris of cobble size far from the normal river channel, whereas ploughed fields on similarly

${ }^{62}$ Collins, R. F.. and Schalk, Marshall, Torrential flood erosion in the Connecticut Valley, March 1936: Am. Jour. Sci., 5th ser., vol. 34, pp. 293-307, 1937. 
situated flood plains were distinctly pitted and scoured. The Hockanum Meadows, for example, carried most of the early flood flow of the river during the $2 \mathrm{~T} / 2$ days of the ice jam but were only locally affected by erosion because of the protection supplied by a frozen sod cover. The ploughed fields of the flood plain northwest of Hadley, on the other hand, were severely gutted by floodwaters under somewhat similar circumstances. Finally, the scouring processes showed remarkable selectivity in areas where pastures and roads or cultivated fields are both present. For example, a 6-foot ditch formed along a small road immediately south of the northwest abutment of the Central Vermont Railway bridge near Northfield, whereas the adjacent grassed area was unaffected.

\section{RIVER-BANK EROSION}

The Recent Connecticut River cut into a considerable variety of materials during its wide lateral swings. At least one exposure of each kind now may be found along its banks, and the rate of bank erosion consequently varies from place to place. It is inconsiderable where the banks are composed of bedrock and slow where the material is till. Soft sediments of Pleistocene and Recent terraces compose most of the river banks, however, and because they are very easily eroded, lateral corrosion of such banks would be a serious problem along the Connecticut were it not for the trees and shrubs that are permitted to grow on the outer margins of most meadows.

Where unusually high banks are seriously undercut, large blocks of material slump slowly and with little rotation to lower positions, and the vegetation growing on their surfaces reestablishes itself nearer river level. The entire outer face of the bank is commonly thus stabilized, because the vegetation encourages deposition of silt, rather than erosion by subsequent floodwaters. This is the condition throughout most of the Northfield and Montague Meadows, as well as in the northern half of the Hadley-Hatfield and Springfield-Willimansett Meadows. In several places where tree growth is thick, undercutting of the banks has caused their upper edges to slump in such a way that the slumped portions are still attached to the adjacent meadow-surface material. This hingelike slump ultimately studs the faces of the bank with trees growing almost normal to it, and forms an effective barrier to river erosion. For example, the outer bank of the bend north of Hadley, with its riverwardtilted trees, has resisted all recent attacks by the Connecticut.

The outer margin of the bend south of Hadley, on the other hand, is now being cut back more rapidly than any other bank on the Connecticut River in Massachusetts. The river changes its direction nearly $130^{\circ}$ and attacks first the low terrace (III) and then a broad flood plain composed of materials deposited by both the Connecticut and the Fort Rivers. (See pl. Ir.) The great flood of 1936 swept away all stabilizing vegetation from the outer margin of this bend, so that the soft terrace and 
flood-plain materials were directly exposed to the full sweep of the current. Between that time and April 1940, when it was last visited by the writer, that part of the bank which bounds the terrace had been cut back several tens of feet, according to nearby residents, and the bank along the low flood plain was cut back more than 150 feet along at least $I, 200$ feet of its length.

Erosion is very rapid on this bend, not only during destructive floods, but also during ordinary high-water stages of the river. Here a bench of varved clay, which is flooded during high-water and flood stages, is overlain by several feet of coarse, loose sands, and these in turn are covered by a thick flood-plain sequence. (See section of terrace on pp. II7-II9.) As the river level drops to normal stage, the freshly exposed sands slump quickly and large sections of the overlying material break off. (See pl. $\sigma, A$.) The next high water sweeps this material away and perhaps again undercuts the banks, so that the entire process is repeated. At its present rate of bank erosion, the Connecticut should intercept the drainage of the Fort River (pl. I , $B$ ) well within the next 2 , centuries, allowing for the improbability of recurrence of extraordinary floods with the, frequency characteristic of the past few years. This is, therefore, a clear example of potential stream intercision. ${ }^{63}$

The cutting off of the great meander north of Mount Tom in 1840 caused considerable changes in the rates of bank erosion throughout the Hadley-Hatfield Meadows. The river gradient at Mount Tom Junction was suddenly increased and this activity created a low knickpoint in the longitudinal profile of the Connecticut. Inasmuch as cut-offs have been shown to have appreciable effects on the upstream profiles of rockbottomed rivers, ${ }^{64}$ it seems reasonable to infer that this knickpoint progressed upstream rather rapidly in the gravel bed of the Connecticut, until gradual flattening made it imperceptible and adjustment was essentially complete. It is significant that within a few years after the cut-off, farmers in the Hadley region complained of suddenly accelerated bank erosion, especially on the two bends discussed in the foregoing paragraphs. This erosion is said to have progressed upstream to the vicinity of Hatfield and North Hadley within a few years, and farmers who had been steadily acquiring "made land" (see p. 54) saw the high-water deposition suddenly cease as the river began to undercut and remove large sections of the banks. Apparently this action. stopped within a decade or two, and most of, the banks again became stable as the river succeeded in readjusting its profile.

Serious bank erosion in the Springfield-Willimansett Meadows is now confined to the broad bend south of Agawam, inasmuch as high, rip-

83 Goldthwait, J. W., Intercision, a peculiar kind of modification of drainage: School Sci. and Math., vol. 8, pp. 129-139, 1908.

a Macar, P. F., Effects of cut-off meanders on the longitudinal profiles of rivers: Jour. Geol., vol. 42, pp. 535-536, 1934. 


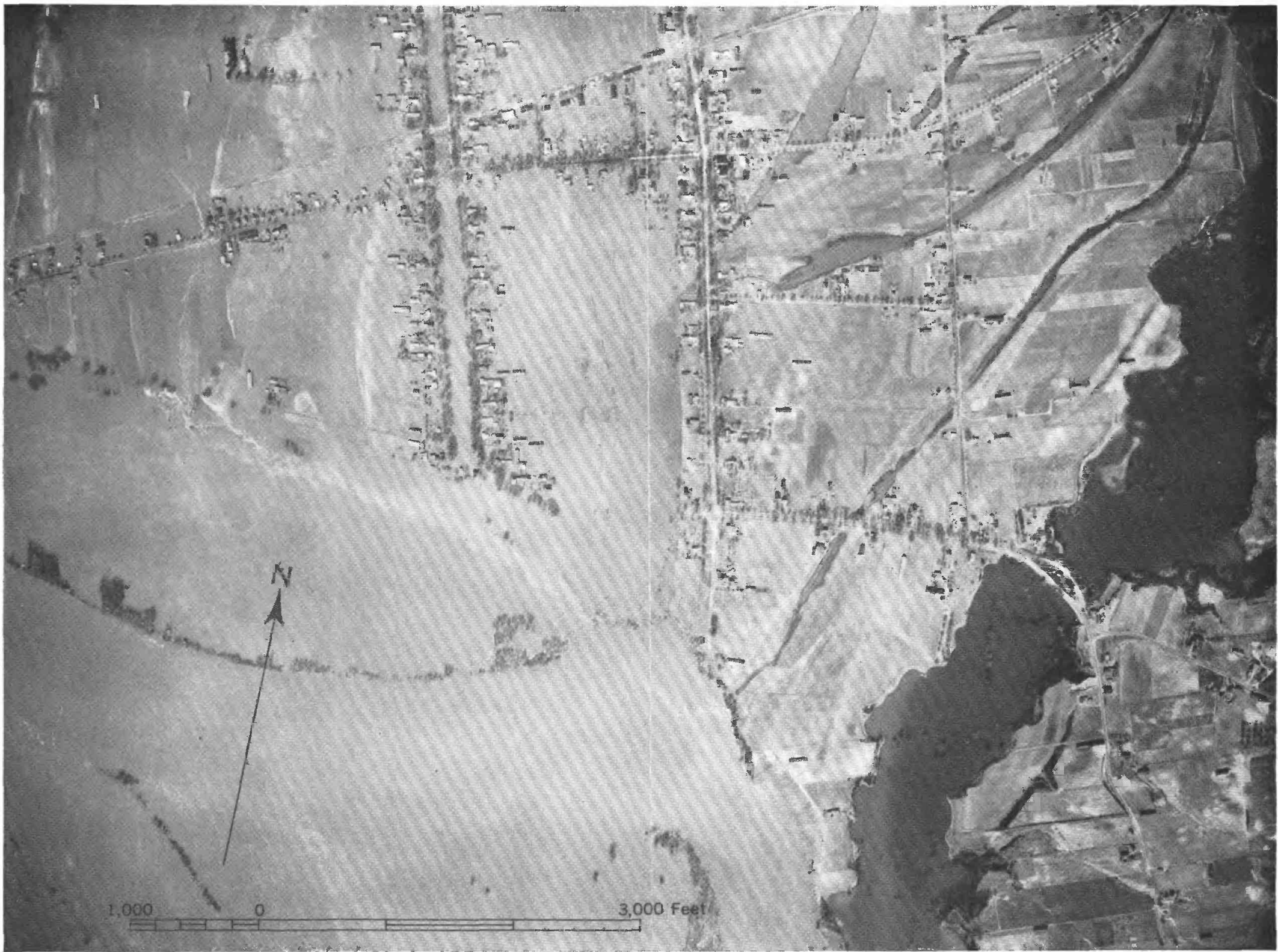

CONNECTICUT AND FORT RIVERS, FLOODWATER INUNDATION IN MARCH 1936.

Note great difference in degree of turbidity of the two rivers. Photograph courtesy of Corps of Engineers, United States Army. 

rapped dikes have been constructed for much of the distance between Springfield and Holyoke. Since 1935, the outer edge of the high flood plain (IV) half a mile northeast of Riverside Park (south of Springfield) has been moved back more than Ioo feet, and several hundred feet of a small road has been destroyed. A rather high bank on the east side of the river north of Chicopee was attacked by floodwaters. in 1936 and 1938 but is now protected by a great dike.

\section{CHANNEL SCOUR}

Comparatively little detailed information is available concerning the configuration of the river channel bottom before, during, and after floods. Although Emerson ${ }^{65}$ emphasized the usual return of shoals and low islands nearly to their preflood positions on the recession of each flood, nothing is known about the history of these shoals and islands during high flood stages. It is reasonably certain that tremendous scouring activity takes place during great floods, because coarse bottom materials are picked up by the swirling waters and dropped on meadow areas, bridge piers not built on bedrock commonly settle vertically as much as io to I5 feet, and the wreckage of steel bridges is known to have been shifted and even raised over obstructions on the channel bottom. Where strong, relatively narrow bypassing currents return to the normal channel, deep pools are formed; on the other hand, currents that have been spread broadly over meadow areas form shoals in the normal channel where they rejoin it. Similar differential effects doubtless exist at each place where the direction of river flow is appreciably altered during floods, whether the feature is to be measured in miles or inches.

As peak-condition waters recede, the main current of the river reverts to its normal channel and begins work on the task of reestablishing the pools and shoals that were disordered by the flood. If the channel plan has not been materially altered by the floodwaters, these pools and shoals are formed again in approximately their usual positions. The fact that they were actually removed in part and later reformed is demonstrated by the effects on the outer portions of low, wooded islands. These reappear in their approximate preflood positions and elevations after the river subsides, but without the slightest trace of their former vegetation.

A fairly rapid progressive shift of shoals has been determined for the area below Hartford, where navigation surveys of the channel have been made several times. Similar exact information for Massachusetts is not available, however, although the statements of persons long engaged in small-boat navigation indicate that slight changes in deep-water channel shape and position have occurred from year to year, and that considerable changes have occurred where great floods appreciably altered the entire channel plan.

es Emerson, B. K., Geology of Old Hampshire County, Massachusetts: U. S. Geol. Survey Mon. 29, pp. 731-732, 1898.

$689520-47-6$ 
Further evidence of the scouring power of the Connecticut River during flood stages was observed 'on the ledges of Triassic sandstone along the channel near the mouth of the Deerfield River, where broad undulatory flutings and potholes have been formed in the rock at a height of about 4 feet above low water. These features are commonly seen along rivers that have a much higher gradient and greater silt content than the Connecticut, and are still more remarkable here because they occur in rocks not ordinarily susceptible to fluting. ${ }^{66}$

\section{SUMMARY OF EROSIONAL EFFECTS}

The heavy runoff that resulted from the storms of March 1936 and Septeniber 1938 speeded up the normal processes of erosion and started several of an anomalous nature, but serious effects in central western Massachusetts were restricted to rather small areas. In the uplands, the principal results took the form of landslides on steep slopes, local gullying in pastures and along roads, and very severe erosion along the large rivers. The destruction of useful land adjacent to the lower Westfield River and the severe damage inflicted on 'many structures along the Westfield, Deerfield, Millers, and Chicopee Rivers were most important.

The central parts of the Connecticut Valley were the scenes of increased gully and rill development on an appreciable scale, especially on the surfaces of glacial terraces. River scour was destructive on fertile flood plains and terraces in the Northfield Meadows and in the southern half of the Hadley-Hatfield Meadows, but in March 1936 it was confined to points of extraordinary floodwater concentration. In general, riverbank erosion was not great, mainly because of the stabilizing influence of vegetation. Undercutting was exceptionally rapid, however, on the outer margins of bends south of Hadley and south of Agawam. Heavy channel scour by the Connecticut during high flood stages apparently causes noteworthy changes in the configuration of the channel, but in most places shoals and deeps seem to return nearly to their preflood positions when the waters recede to more normal levels. Shifting of these features is appreciable over a period of years, however.

\section{FLOOD SEDIMENTATION}

\section{GENERAL FEATURES}

MODES OF TRANSPORTATION

Sediment is transported by running water in two general ways, traction and suspension. Individual masses of the tractional or bed load are moved by several processes. Those which move along the irregular surface of the bed are rolled, except the more nearly tabular fragments,

${ }^{3}$ Maxson, J. H., and Campbell, Ian, Stream fluting and stream erosion: Jour. Geol., vel. 43. pp. $729-744,1935$. 
which advance by sliding. The irregularities in the stream bed, together with the turbulence they produce in the current, cause some of the finer and lighter particles to skip and leap along slightly above the channel bottom, a process known as saltation. ${ }^{67}$ The thickness of the zone in which saltation is active varies with the velocity of the stream, the degree and nature of turbulence of the current, and the type of the bed load.

The zone of saltation passes gradually upward into the zone of suspension, and the particles progressively decrease in size and density. Particles are held in the zone of suspension by the turbulence of the current; as velocity increases, their coarseness increases through the addition of the finer particles of the bed load. Conversely, as velocity decreases, the larger particles in the suspended load pass back into the bed load. This interchanging process is constantly active because local irregularities in velocity and turbulence are ever present; when either of these factors is progressively increased or decreased along the entire stream, the interchange becomes similarly progressive. As more and more particles pass from the tractional load to the suspended load, the force of the water moves more of the coarser material along the stream bed. This process is very effective during floods.

Although much of the sediment carried by the large rivers in the Massachusetts portion of the Connecticut River drainage basin during the two recent great floods must have been in the form of bed load, most of the flood deposits now visible on flood-plain and terrace surfaces undoubtedly represent suspended load. Vast amounts of such material are evidently of the type ordinarily moved by traction, but it was held in suspension during these floods because of their extraordinarily high velocities and turbulence.

Many investigations have been made during recent years to supplement. the classic experiments of Gilbert at the University of California in 1907'o9. The problems of transportation of sediment have been attacked theoretically and experimentally, and many field studies of suspended loads in rivers have been made; similar investigations of tractional loads have been started during the past few years. References to many of these investigations are included in the bibliography.

\section{FACTORS THAT INFLUENCE TRANSPORTATION AND DEPOSITION OF SEDIMENT}

The quantity of material moved by a given stream, either by traction or by suspension, is its load. The maximum amount of material that the stream is able to transport is its capacity, and the dianeter of the largest particle it can move is a measure of its competence. It follows that the load can never exceed the capacity and that the capacity and competence

${ }^{67}$ Gilbert, G. K., The transportation of debris by running water: U. S. Geol. Survey Prof. 1 Paper 86, pp. 26-30, 1914. McGee, W. J., Outlines of hydrology: Geol. Soc. America Bull., vol. 19. p. 199, 1908. 
undergo changes in the same direction, with all changes in the factors that govern them. The variables that influence stream capacity, as summarized by Gilbert, ${ }^{68}$ are included here because of their importance in the interpretation of conditions under which the recent flood deposits of the Connecticut River were laid down:

Capacity varies with slope. The greater the slope the greater the capacity; and the change in. capacity is always larger than the change in slope.

Capacity varies with discharge. When discharge is increased the resulting increase in capacity is greater than the increase in discharge; the capacity per unit of discharge is increased. But an increase in discharge does not enhance capacity so much as the same ratio of increase in slope.

Capacity varies with the character of the debris transported. The lower the specific gravity of the debris the greater the capacity - that is, the greater the weight of load which may be transported. The finer the debris the greater the capacity. $* * *$

Capacity varies with the ratio of depth of water to width of stream. In the main, capacity increases with increase of the ratio, $* * *$ but the opposite rule applies to very small values of the ratio. $* * *$

The ratio in which capacity is modified by a change in slope, discharge, fineness of debris, or depth of current is greater when the conditions are near competence than when they are far above competence. In other words, capacity is most sensitive to change in the conditions which control it when near its lower limit. $* * *$

If a stream which is loaded to its full capacity reaches a point where the slope is less, it becomes overloaded with reference to the gentler slope and part of the load is dropped, making a deposit. If a fully loaded stream reaches a point where the slope is steeper, its enlarged capacity causes it to take more load, and the taking of load erodes the bed. If the slope of a stream's bed is not adjusted to the stream's discharge and to the load it has to carry, then the stream continues to erode or deposit, or both, until an adjustment has been effected and the slope is just adequate for the work.

In making definite comparisons between capacity and mean velocity of a stream, Gilbert ${ }^{69}$ states :

If slope be the constant, in which case velocity changes with discharge, capacity varies on the average with the 3.2 power of velocity. If discharge be the constant, in which case velocity changes with slope, capacity varies on the average with the 4.0 power of velocity. If depth be the contant, in which case velocity changes with simultaneous changes of slope and discharge, capacity varies on the average with the 3.7 power of velocity.

Thus the capacity of a river increases very rapidly with an increase in its velocity, regardless of whether slope, discharge, or depth is constant, or whether all three vary. All the above-quoted statements apply to bed load or suspended load, provided that each is considered separately.

In discussing turbulence, a factor whose importance in influencing debris movement was minimized by Gilbert, Leighly ${ }^{70}$ states that velocity

${ }^{68}$ Gilbert, G. K., Hydraulic-mining debris in the Sierra Nevada: U. S. Geol. Survey Prof. Paper 105, pp. 26-27, 1917.

${ }_{69}$ Gilbert, G. K., The transportation of debris by running water: U. S. Geol. Survey Prof, Paper 86, p. 11, 1914.

${ }^{70}$ Leighly, John, Turbulence and the transportation of rock debris by streams: Geog. Rev., vol. 24, pp. 453-464, 1934. 
is a purely empirical function of such fundamental factors as' gradient and discharge, and that the "* * * characteristic distribution of intensity of turbulence $* * *$ is of prime significance for the configuration of stream channels composed of movable rock debris." he further states:

* * * it appears fairly certain that the behavior of such streams-the formation of multiple channels and midchannel bars, for example-is an expression of the development of more or less parallel bands of water, in each of which there is a thread constituting a local maximum of velocity. If, as appears probable, each thread of maximum velocity is accompanied by two threads of maximum turbulence, * * * the distribution of turbulence is complex.

Finally he makes the statement: "All stream deposits are formed in areas that are lateral to some thread of maximum velocity and its flanking threads of maximum turbulence."

\section{DEPOSITION OF BED LOAD}

\section{CHANNEI, DEPOSITION}

\section{CONNECTICUT RIVER}

The coarse, pebbly material carried as tractional load in the maximumvelocity channel of the Connecticut River during the great flood of 1936 and the hurricane flood of 1938 is now available for study in few places. Where deposited as bars, it has been subsequently removed by corrasion or veneered with coarse sands, so that little of it is exposed in the normal channel above low-water level. Such materials are found, however, in those few places where the channel with maximum velocity during the floods did not coincide with the normal channel, and are represented by local veneers on the bottoms of deep, bypass scours and swirl pits, and at a few points along faintly scoured outer margins of favorably situated flood plains and terraces. These veneers are of undoubted recent river origin, because there is no immediately adjacent source of such coarse materials. Whether the force of the current was of sufficient strength to lift the largest and heaviest fragments of the bed load to the floors of these scour areas, most of which are several feet above mean river level, is a question, and to this extent the veneers may not represent the bed load of the normal channel at peak stage. The difference, however, probably is not great.

The tractional material on the floor of the scour channel near the east edge of Moose Plain, north of Northfield (pl. $4, C$ ), consists of pebble gravel and very coarse, clean sand, a sieve analysis of which is shown graphically in plate $\mathrm{\tau} 8, A$. The pebbles are dominantly of silicic crystalline rocks, with a subordinate amount of slate fragments. This material is covered by an inch or less of fine, loose, micaceous sand, a large part of which is probably of eolian origin. Similar materials veneer the bottom of the scour channel immediately north of Munns Ferry. (See map of Northfield quadrangle.) 
If the local patches of coarse sand found near the scoured edges of the low terrace (III) east of Bradstreet (pl. 5 and Mount Toby quadrangle) are considered representative of bed-load deposits, the tractional flood load of the Connecticut River in the Hadley-Hatfield Meadows was considerably finer than in the Northfield Meadows. Such a downstream decrease in size of particles is probably more apparent than real, however, because of the force required to lift material more than 40 feet from the river bottom to the upper surface of terrace III, which immediately flanks the river throughout much of the Hadley-Hatfield Meadows, was probably great enough to cause rejection of large quantities of the coarser material by the upward-moving currents.

Bed-load deposits in interscroll depressions near the margin of the flood plain opposite Riverside Park (south of Springfield in SpringfieldWillimansett Meadows) consist of very coarse, micaceous sand, with sparse pebbles of pea size. Scattered pebbles and cobbles have been observed in protected places along the river 3 miles upstream, but are probably contributions of the Westfield River, the mouth of which lies less than a mile to the north. The Connecticut is unable to transport much material of this size, even during flood stages. This is indicated by a gravel fan that projects far out into its channel at the northerly mouth of the Westfield River.

Where the river gradient is markedly steepened, as in the Turners Falls Gorge and Holyoke Narrows, bed-load capacity is increased accordingly. However, the sources of materials coarser than those being supplied by the Connecticut from its upstream, lower-gradient reaches are inconsiderable. Hence the river is distinctly underloaded as it passes through its bedrock gorges, where it tears off and carries away large blocks of Triassic sandstone from its bottom, only to drop them where the gradient flattens out downstream. This increased transporting capacity was most clearly demonstrated at Holyoke during the flood of 1936. When the waters subsided, it was found that the huge granite blocks dislodged from the upper edge of the dam by ice buffeting had been carried downstream for distances as great as half a mile, a distinct contrast to tractional transportation in the meadow areas both upstream and downstream.

\section{TRIBUTARY STREAMS}

An examination was made of bed-load deposits along those parts of the Sawmill, Millers, Deerfield, Westfield, and Chicopee Rivers that flow across the Connecticut Valley floor. Field inspection showed that these deposits generally consist of rock fragments considerably coarser and more heterogeneous than most of the tractional materials of the Connecticut River. Where samples were collected for mechanical analysis, material smaller than 3 -inch mesh was taken in gallon containers for sieving, and the coarser fragments were carefully measured in the field 
and their respective weights computed, with certain allowances for variation in composition. The combined results are plotted as sieve analyses on plate I8.

The Sawmill River rises in the central upland area and flows westward through a narrow canyon into a small, nearly flat-floored valley $\mathrm{I} .3$ miles south of Montague. (See fig. 3.) Here it bends sharply and flows northward through the valley, which is an isolated area underlain by bottom deposits of late glacial Lake Montague, ${ }^{71}$ and then it bends again near

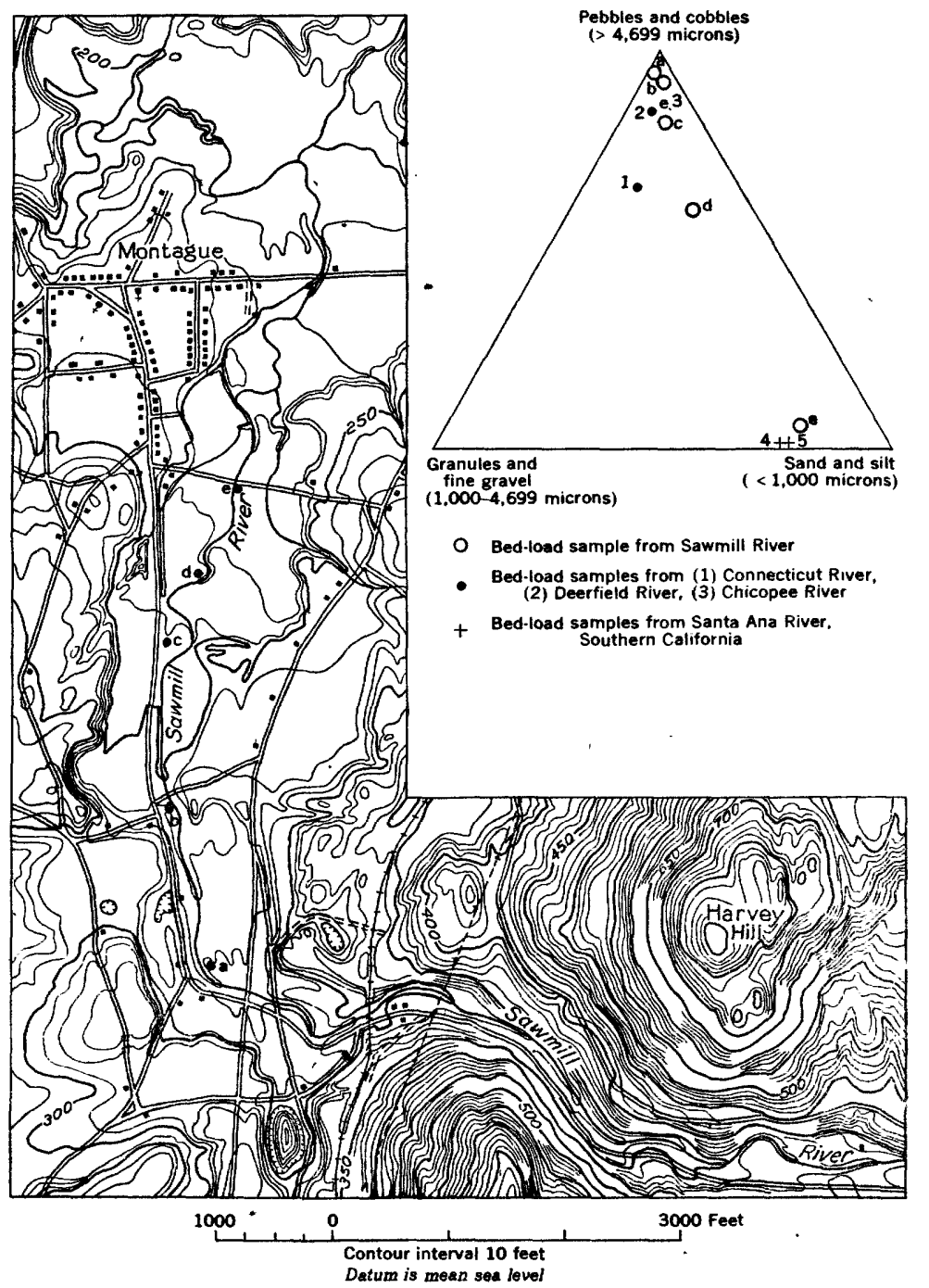

Figure 3.-Bed-load characteristics of Sawmill River south of Montague, Mass.

71 Emerson, B. K., Geology of old Hampshire County, Mass.: U. S. Geol. Survey Mon. 29, p. $673,1898$. 
Montague and flows westward and southwestward to join the Connecticut. The abrupt decrease in gradient at the point where it enters the valley west of Harvey Hill has caused it to release most of its tractional load between this point and the southern limits of Montague. Deposition of boulders and very coarse cobble gravel has formed a fan immediately downstream from the highway crossing about 0.2 mile west of the railroad. This deposition has been checked recently by dredging the channel. Abandoned stream courses on the north slope of the fan are clearly shown by one of the contours on the map. Anastomosing highwater channels are numerous a short distance downstream, and in the vicinity of Montague the low-water channel itself is braided.

Typical tractional material was collected from a riffle surface a foot above mean water level on the inside of the first large bend (a, fig. 3 ), and two other samples ( $b$ and $c$ ) were taken from somewhat similar situations 0.3 and 0.5 miles, respectively, downstream from a. Their mechanical analyses (pl. I $8, B$ ) indicațe a progressive downstream decrease in coarseness, which is clearly a reflection of the waning capacity of the river in this low-gradient part of its course. Samples a and b contain very little fine material, doubtless because the riffles from which they were collected are subject to annual scour by underloaded waters, so that nearly all sand and silt particles are removed to depths of 6 inches or more. Thus the original deposits were probably much more poorly sorted than their present remnants. The material in sample $c$ lay adjacent to a small high-water bypass channel and so was not affected to the same degree by this scour removal of finer particles.

Sample $d$ was collected from the inner edge of a sharp bend 0.6 mile downstream from a; it consists of bed-load material deposited by the hurricane flood water and apparently has escaped subsequent scouring. This material is not only finer than materials upstream, but it is much more poorly sorted. The mechanical composition of sample e, collected from a low river flat 0.7 mile downstream from a, represents a typical sandy veneer deposited on a pea-pebble gravel bar during either a late stage of the same flood or a subsequent high-water stage of the river. Some of the coarser fragments of this material may have been derived from the underlying gravel through the action of turbulent currents.

The progressive characteristics of samples a to e probably are generally representative of small-river deposits downstream from a point of marked decrease in slope of its gradient. On figure 3 they are compared on a triangular diagram with bed-load samples from the Santa Ana River, ${ }^{72}$ a larger but somewhat analogous stream in southern California, and with ordinary high-water channel samples from the Connecticut, Deerfield, and Chicopee Rivers.

The Millers River, another west-flowing stream, issues from its nar-

72 Troxell, H. C., and Peterson, J. Q., Flood in La Cañada Valley, Calif. January 1, 1934: U. S. Geol. Survey Water-Supply Paper 796-C, pp. 88-89, 1937. 


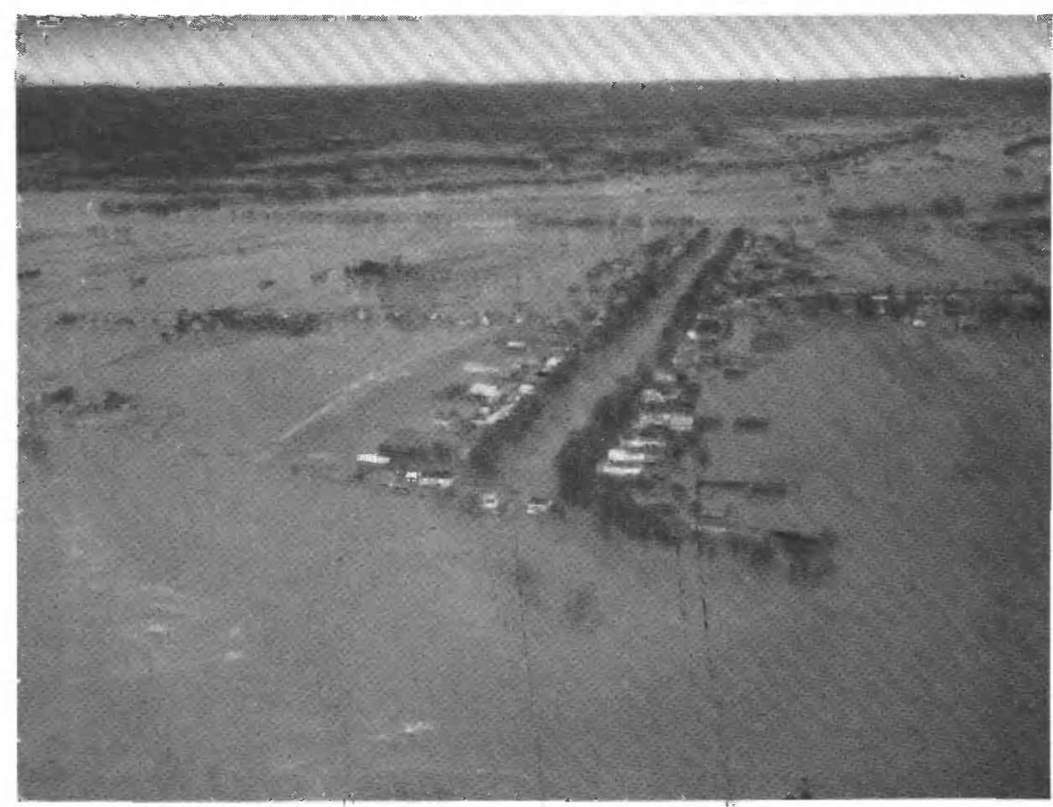

A. GENERAL VIEW NORTHWEST, SHOWING HADLEY IN MIDDLE FOREGROUND. Most of the inundated area is the high Connecticut River flood plain (IV).

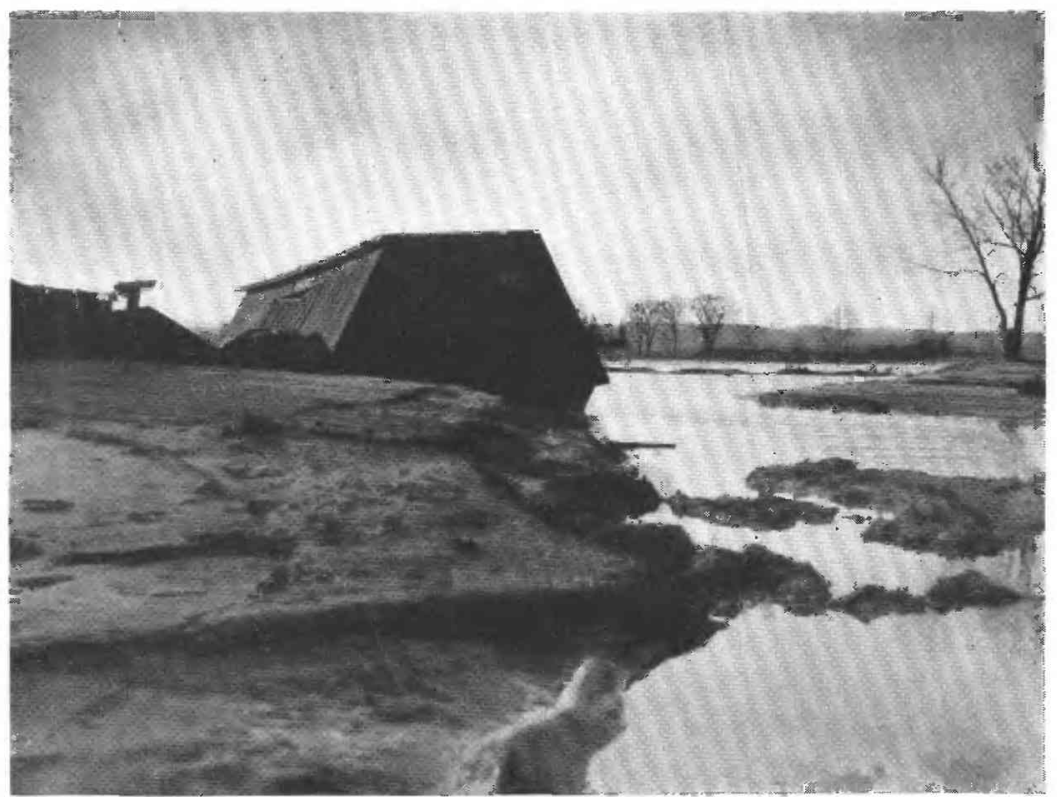

B. DETAIL OF FLOOD.PLAIN DAMAGE.

Thick deposit of sand at left, heavy scour on right.

HADLEY AREA DURING FLOOD OF MARCH 1936.

Photographs courtesy of Holyoke Daily Transeript-Telegram. 


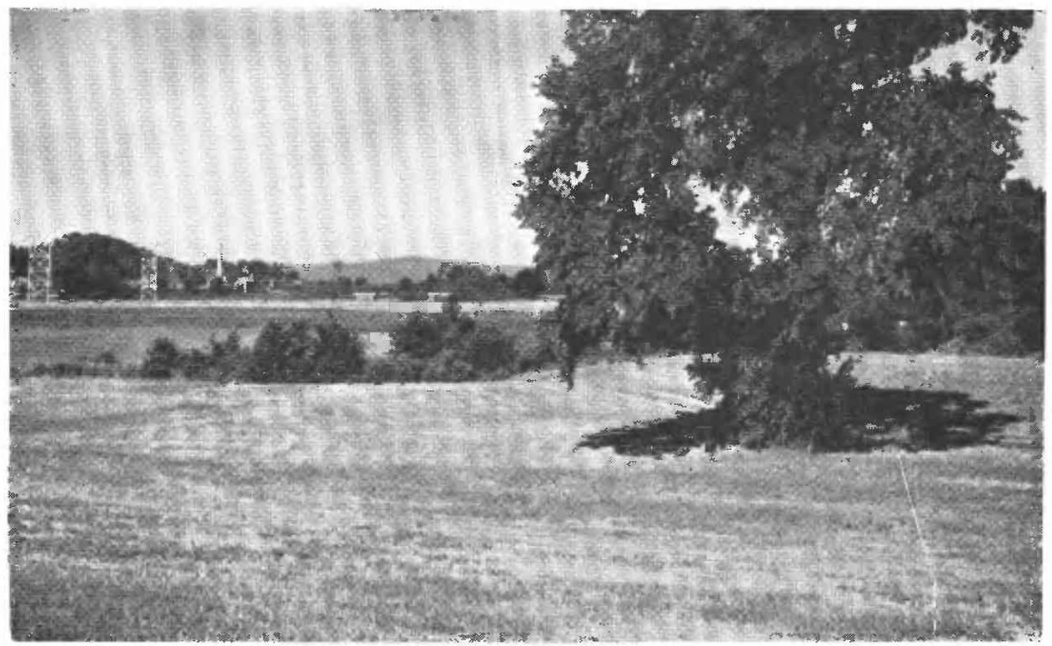

A. NORMAL APPEARANCE OF MEADOWS AND RIVER, JULY 1939.

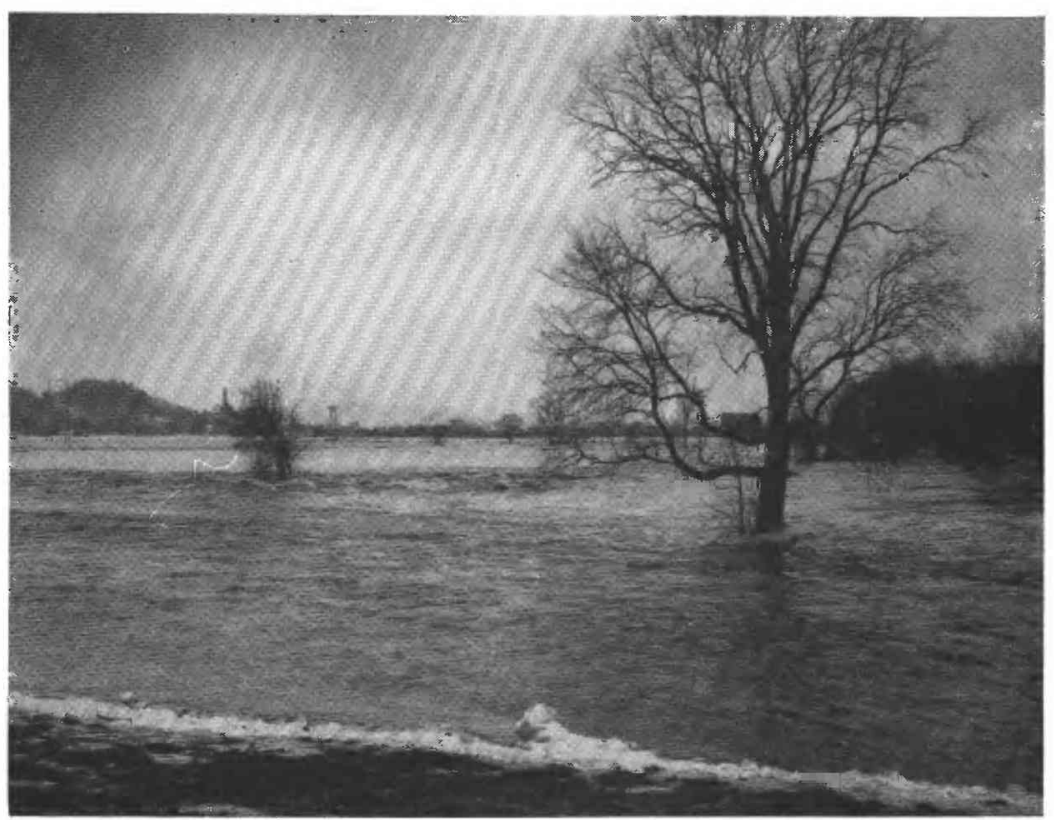

B. SAME AREA DURING FLOOD OF MARCH 1936.

RIVER CONDITIONS NEAR MOUNT TOM JUNCTION, LOOKING WEST. Photographs courtesy of Holyoke Daily Transcript-Telegram. 
row gorge at Millers Falls, makes a very sharp bend, and thence flows northward to join the Connecticut through the flat-bottomed valley it has cut into its proglacial deltaic deposits ( $7 / 2-$ minute Greenfield and Millers Falls quadrangles). Depositional conditions were therefore similar to those along the Sawmill River south of Montague. Three bed-load samples were collected in this valley. Sample I (pl. I8, $A$ ) was obtained from the very coarse, heavily scoured rubble on the slip-off slope of the bend immediately west of Millers Falls, and is remarkably well sorted. Sample 2 was collected from the same slip-off slope, but at a slightly higher, more protected position on the downstream end of the bend. The material has evidently retained a large portion of its finer constituents. Sample 3 represents the sandy capping of a gravel bar 0.4 mile downstream from sample $I$, and is strikingly similar to sample e from the Sawmill River.

A riffle on the south side of the Deerfield River 300 feet west of Stillwater Bridge (Shelburne Falls quadrangle) was sampled at a point approximately 3 feet above mean water. The sieve analysis for this material is plotted on plate $\mathrm{I} 8, A$. The curve is of the same general shape as that for material collected from a similar environment on the south side of the Chicopee River 0.5 mile west of Bircham Bend (Springfield North quadrangle). Bed-load samples were collected from riffles along the Westfield River 2.5 miles west of Westfield (sample I), 2 miles east of Westfield (sample 2), and 2.2 miles west of West Springfield (sample 3); their sieve-analysis curves appear in plate I8, $A$. They show a sorting unusually good for deposits so coarse, but this is probably due in part to the previously discussed processes of scouring.

The pebbles and cobbles of these tributary bed-load deposits are dominantly crystalline rocks, especially along the rivers in the northern part of the state. Silicic igneous types, granitic gneiss; schists, quartzite, intermediate and basic igneous types, phyllite, and slate are most common in approximately that order of abundance. Fragments of Triassic rocks are present in large amounts along the Chicopee River, and are fairly common along the lower Westfield. In general, there is a higher proportion of metamorphic types along the eastward-draining rivers that flow in the Berkshire Hills and of igneous types on those that flow from the central uplands.

\section{DEBRIS FANS}

The excessively heavy precipitations of the two storms of March 1936 caused the growth of several small debris fans where none had been known to exist before. They contrast with older, well-established fans, which are situated along the courses of perennial streams or at the mouths of large gullies, and have surfaces commonly covered with vegetation and veneered with rather fine, silty material.

The best observed example of a very recent debris fan lies in a small basin at the foot of the north slope of Taylor Hill, 0.9 mile west-north- 
west of Montague. It is a low, perfectly formed alluvial cone that spreads out from the mouth of a small, deeply-gullied intermittent stream (see p. 69) for more than $45^{\circ}$ feet in a general northerly direction. (See pl. I7,B.) A small, ungullied perennial brook that flows into the basin from the southeast has supplied little detritus to the fan. This coarse deposit covers what was once a pasture, and its rapid growth is ascribed by nearby residents to heavy, gully-forming runoff in the valley of the intermittent stream, especially during March 1936 and September 1938. Inasmuch as further headward growth of the gully is now prevented by a protected roadcrossing, and its downstream growth has been halted by bedrock in several places, the fan at its mouth may not increase much in size during future periods of heavy runoff.

Although this alluvial cone is small, it possesses nearly all the features characteristic of similar, but larger forms in the arid southwest, including a concave profile, apronlike plan, irregular outer margin, complex distributary channels, and an incised apex. Samples were collected from surfaces immediately adjacent to small spreading channels at the apex, and at points 200, 300, and 430 feet down the slope from the apex; they show the expected progressive decrease in coarseness. (See pl. I $8, B$.) Further, the bed load was evidently very poorly sorted, a condition which doubtless favored its mobility. ${ }^{73}$ It is true that much of the material may have been carried onto the fan as successive debris waves in the manner outlined by Troxell and Peterson ${ }^{74}$ in their studies of alluvial-fan flooding in southern California. The triangtular diagram in plate $18, C$ furnishes a comparison between the bed-load samples from the Taylor Hill debris fan and those from the alluvial cone of Pickens Creek, southern California, ${ }^{75}$ which has been the object of detailed flood studies.

A second example of a very recent fanlike bed-load deposit lies 0.4 mile southwest of North Sunderland Cemetery (Mount Toby quadrangle), adjacent to State Highway 63. It is confined to an elongated area several hundred feet in length, through which flows a very small brook, and its presence is clearly the result of a sharp decrease in the gradient of the brook.

\section{DELTAS}

Deltas of recent origin are most common in the upland areas, and occur in the channels of large rivers wherever tributary streams flow into them. They consist of very coarse gravel, and represent torrential deposition from the high-gradient tributaries during flood stages on the rivers into which they empty. Such gravel deltas are especially numerous along the Deerfield River between Shelburne Falls and Zoar, and bear

${ }^{73}$ Gilbert, G. K., The transportation of debris by running water: U. S. Geol. Survey Prof. Paper 86, pp. 178-179, 1914.

74 Troxell, H. C., and Peterson, J. Q., op. cit., pp. 88-92, 1937.

75 Troxell, H. C., and Peterson, J. Q., op. cit., pp. 88-90, 1937. 
testimony to its low gradient with respect to those of the smaller streams that drain into it. Trimming and reworking of these deltas by the Deerfield has destroyed much of their original structure and has coarsened their constituent materials by removal of the finer components.

Evidence of temporary reversal of these conditions was observed along the banks of the same river at several small railroad culverts (pl. $33, A$ ), the openings of which were apparently inadequate to pass the debrisladen flood waters of normally small tributary brooks. When the culverts became partly or wholly clogged on their upstream ends' by accumulations of wreckage and other debris, the waters of the brooks sought exit elsewhere. Thus deprived of rapidly flowing water from their upper reaches, the parts of the tributaries in the downstream portions of the culverts were relatively quiet and acted essentially as embayments of the swollen Deerfield River. From the latter stream they received deltaic deposits of sand and gravel, and for this reason many of the small brooks are now engaged in carrying such flood deposits away from the culverts. The sediments have foreset beds that dip upstream with respect to the tributaries, and the depositional forms are strictly analogous to the "reverse delta" noted by Leighly ${ }^{76}$ on the Colorado River at Bright Angel Creek.

During the recent floods the Westfield River added appreciable quantities of coarse gravel to its delta in the Connecticut River opposite Springfield. There is evidence of a similar, though less marked delta at the mouth of the Chicopee River. Both the Millers and Deerfield Rivers drop the coarser phases of their bed loads in the flat-floored valleys through which they flow before reaching the Connecticut; thus recognizable deltas are absent at their mouths. The distributions and relative positions of bed-load deltas indicate clearly that the competency of the smaller, higher-gradient streams is greater than that of the larger streams into which they flow, and therefore that bed-load competency is increased more by increase in gradient than by an increase in discharge. This is the same relation as that noted by Gilbert ${ }^{77}$ in connection with capacity.

The Connecticut River inundates the lower parts of its tributaries in times of flood. When the debris-laden tributary waters encounter these relatively quiet embayments, they lose much of their velocity and turbulence. The resulting deposition occurs in the normal channels of larger tributaries and thus is now not readily seen, but in many small brooks it developes features of unusual appearance. An excellent example of such features is afforded by a small, unnamed brook I.2 miles north of French King Rock. (Millers Falls quadrangle.). Where its flood waters came

76 Leighly, John, Turbulence and the transportation of rock debris by streams: Geog. Rev., vol. 24, pp. 463-464, 1934.

77 Gilbert, G. K., Hydraulic-mining debris in the Sierra Nevada: U. S. Geol. Survey Prof. Paper 105, p. 26, 1917. 
out from a small canyon into the broad meadow near Stacys Ferry, a fan of coarse gravel was laid down. The stream now crosses this fan and continues with uniform slope down a broad swale in the meadow for a distance of 300 feet, at which point its narrow, gravel-strewn normal channel broadens into a nearly circular area about 25 feet in diameter, which is covered with coarse gravel. Downstream from this deposit the channel reassumes its normal appearance. The only explanation that seems reasonable for the deposition of such coarse material over a sodcovered pasture at this point is that the deposit is a delta formed in a quiet-water embayment of the Connecticut River during the March 1936 flood. The position of the delta approximately 3 feet below the highwater mark on a nearby barn implies that rapid deposition, perhaps as a debris wave, occurred along the brook during flood-peak conditions on the Connecticut.

Few tributary streams formed flood deltas of material as coarse as that above. Most of them appear to have formed thin, sandy deltas progressively upstream as the Connecticut River level rose. It is doubtful whether this process was repeated to so great a degree in a downstream direction as the Connecticut receded, because the small brooks returned to normal flow sooner than the main stream did. The typical relations of such tributary deposits to sediments laid down in the embayment by the Connecticut are shown in figure $4, d$ and $e$. These Connecticut River sediments were of course carried as suspended load, and this may be true of the finer deposits of the tributaries as well. The only other observable deltas consisting of materials definitely recognizable as recent flood bedload deposits are those built into water bodies temporarily ponded by clogged bridges, landslides, and similar features.

\section{SUSPENDED-LOAD DEPOSITS OF RECENT FLOODS}

GENERAL FACTORS

It seems probable that an exceedingly small portion of the recent flood deposits laid down in areas inundated by the Connecticut River represents bed load in the normal sense. It is true that normally suspended particles carried onto flooded areas of meadowland were probably transported tractionally for appreciable distances immediately before they were deposited, but this may be viewed as a transitional stage of rather short duration and slight consequence. In the same manner, some particles on flooded surfaces of meadows may have been first set in motion as tractional load, but the strong turbulence in the shallow waters covering the meadow probably converted them quickly into suspended load. For these reasons, the deposits next to be described are considered to have been transported in suspension, and as such were subject to the actions and effects of the variables that influence stream capacity.

All of these variables that bear directly on the transportation and de- 
position of debris apply prímarily to normal stream channels, but can be applied equally well to the temporary and rapidly changing channels of streams in flood. The Connecticut River has presented an amazingly complex series of channel sections from place to place during the floods because of its extensive terrace and flood-plain system and its irregularities of longitudinal profile. When the river rises over its banks and occupies a given flood-plain area, for example, the stream velocity and turbulence across the flooded surface vary with the depth of water, the smoothness and slope of a flooded area, the shape and position of the banks where the water leaves its normal channel, and the amount of water so diverted. This set of conditions is repeated as each successively higher flood-plain and terrace level is flooded.

The factors mentioned vary considerably during different flood stages, and doubtless have secondary effects on the overloaded normal channel. Although it is impossible to evaluate them exactly, much can be learned of their general effects from the type of suspended materials deposited by the flood waters, if each individual deposit is properly correlated with its appropriate stage and corresponding type of flooding (pl. 8) when it was laid down. Hence the study of the flood deposits of the Connecticut River was approached by treating each recognizable layer individually wherever possible, and evaluating its particular depositional environment as accurately as observations permitted. Such an evaluation of the genetic significance of a layer and of the entire deposit of which it is a part may aid in the interpretation of older deposits now in river terraces, and may furnish clues in studying consolidated deposits of possible flood-plain origin.

\section{Distribution, APPEARANCE, AND PRESERVATION}

The distribution of the recent flood deposits from suspended load in the Massachusetts portion of the Connecticut Valley corresponds to the boundaries of the flood of March 1936, which are shown in plate 10. The I936 flood covered $3^{8}$ square miles, and the hurricane flood about 35 square miles; these areas include the inundated meadows of the lower Deerfield and Westfield Rivers. The materials laid down vary greatly in thickness. For example, test pits at favorable sites near the banks of the river exposed more than 6 feet of sediments ascribable to the two floods; whereas deposits of the same age are represented near the margins of flooded areas by extremely thin veneers of silt.

It is estimated that a blanket of sediment was deposited over the entire flooded area to an average depth of $13 / 8$ inches during March 1936 . This estimate is based on 6I I measurements of recent flood sediments in the valley, made across flood-plain and terrace areas, along small tributary streams, and along the banks of the Connecticut. On the same basis of estimation, a $7 / 8$-inch cover was added in September 1938. If the average weight of the materials is assumed, on the basis of their composition, to 
be I40 pounds per cubic foot, it is concluded that about $8,500,000$ tons of flood debris was carried into the valley as suspended load.and deposited there by the 1936 flood waters alone. The immensity of this deposit is demonstrated by a comparison with the 51,000,000 tons of material deposited by the Ohio River during January and February $1937^{78}$ over an area 65 times as great.

The general appearance of the flood deposits varies according to their original sedimentary characteristics, and also changes perceptibly with prolonged exposure in an undisturbed condition. For example, immediately after subsidence of the floods, the deposits on meadow surfaces appeared as rather thick covers of compact, dark brown sandy silt, commonly with broad current ripple marks. (See pl. 19,A.) As this material dried out deep mud cracks formed and divided it into large, polygonal blocks, which became much lighter in color. Undisturbed surfaces were soon covered with eolian material derived from nearby more rapidly drying deposits. The thicker, sandier deposits near the river banks (pl. $\mathrm{r}_{9}, B$ ), which were light gray to buff, underwent less change, although their surfaces were modified by wind action, slump, and the growth of vegetation. The deposits least changed are near the mouths of small tributary streams. They have been saved from wind scour by their protected positions and still retain their surface layers of silt, which are dark gray to brown and deeply mud-cracked.

Undisturbed flood deposits that appear to retain their genetic characteristics for long periods are restricted to small areas. Most of the flood sediments on the terrace and flood-plain surfaces have been thoroughly mixed by deep ploughing with the underlying loamy soil, and many others have been artificially removed. (See pl. I9.) Some thin deposits have been incorporated into underlying older materials by the action of roots, worms, rain, and frost. Deposits probably laid down by the flood of November 1927, for example; have been observed in all stages of incorporation, particularly in areas farther back from the Connecticut River. Finally, some have been completely removed by natural causes, such as stream and sheet erosion or wind scour.

Interpretable flood deposits are most commonly preserved along the banks of the Connecticut, on the banks of small tributary streams near their mouths, on the margins of swamps and other areas unsuited to cultivation, and on the walls of scour pits and scoured flood channels. In addition, small remnants are preserved on flood-plain areas near trees, roads, and buildings, and generally can be recognized by the vegetation growing through them. Search for undisturbed deposits is difficult in thickly settled areas unless made soon after the flood subsides. Vacant lots, parks, playgrounds, and overlooked corners of back yards are the

${ }^{78}$ Report of the Chief of the Soil Conservation Service, 1937, p. 21. 
locations most favorable for preservation, but the deposits themselves must be interpreted with caution.

\section{MODE OF STUDY}

\section{FIELD INVESTIGATIONS}

As these flood studies were made more than 3 years after the flood of 1936, the debris line marking its maximum outer margin was observed in but few places. The flood-crest heights recorded by stream gages and high-water marks on trees, banks, and buildings were used by Geological Survey engineers in estimating the position of this outer margin on largescale topographic maps of the valley area. The accurate location of the flood line was made available to the writer, and was supplemented with published maps ${ }^{79}$ for field use. No similarly accurate boundaries of the hurricane flood were used in the work, because their approximate positions could be obtained by comparison with the levels of the great flood.

Recent flood sediments were studied at 6I I localities in the valley, selected to obtain the most uniform distribution consistent with known occurrences of reasonably intact deposits. Detailed sections were measured and interpreted at 204 of these localities, and 262 representative samples were collected. The sections were divided for detailed study into members that represent sedimentation units or small groups of sedimentation units. As defined by Otto, ${ }^{80}$ a sedimentation unit is "that thickness of sedimentation which was deposited under essentially constant physical conditions." No samiple contained material from more than one such unit; this procedure thus constituted "environmental sampling." 81 Typical flood-deposit sections are illustrated in plate 20 and the corresponding measured sections appear in table Io.

In table Io all station localities are numbered, and the number of each is prefaced with a letter that indicates the quadrangle in which it lies. The relative positions of these quadrangles are indicated on plate 3. The symbols employed are as follows:

$\begin{array}{llll}\text { E } & \text { Easthampton } & \text { N } & \text { Northfield } \\ \text { G } & 7 \frac{1}{2} \text {-minute Greenfield } & \text { SF } & \text { Shelburne Falls } \\ \text { H } & \text { Hawley } & \text { SN } & \text { Springfield North } \\ \text { MF } & \text { Millers Falls } & \text { SS } & \text { Springfield South } \\ \text { MH } & \text { Mount Holyoke } & \text { Wo } & \text { Woronoco } \\ \text { MT } & \text { Mount Toby } & \text { WS } & \text { West Springfield } \\ \text { MTom } & \text { Mount Tom } & & \end{array}$

70 Massachusetts Geodetic Survey, High water data, flood of March 1936 in Massachusetts, figs. CTR-I to CTR-XVI, Massachusetts Dept. Pub. Works, Boston, 1936.

80 Otto, G. H., The sedimentation unit and its use in field sampling: Jour. Geol, vol, 46, p. $575,1938$.

81 Otto, G. H., idem, p. 570, 1938. 


\section{TABLE 10.-Sections showing typical flood deposits}

[Materials are those illustrated on pl. 20]

Station MTom 3

[N. bank of Goldine Brook, E. of bridge on U. S. Highway 5. See pl, 20,A. Appraximate distance below flood peak, March 1936, was 21 feet]

$a^{\prime}$. Silt, clayey, blue gray (1939).

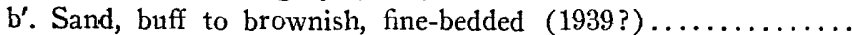

c'. Silt, dark brown; locally rootlet-filled $(1938) \ldots \ldots \ldots \ldots \ldots$

d'. Sand, medium to fine, buff; clearly pseudo cross-laminated. through lee-side concentration of magnetite and garnet on current ripples $(1938) \ldots \ldots \ldots \ldots \ldots \ldots \ldots \ldots \ldots \ldots \ldots$.

$\mathrm{e}^{\prime}$. Sand, buff to brownish, fine, thinly bedded; contains local

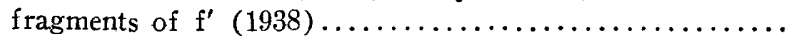

Inches

$f^{\prime}$. Silt, dark brown, root-filled; contains mud cracks filled by $\mathrm{e}^{\prime}$ and $\mathrm{d}^{\prime}(1936)$.

$g^{\prime}$. Similar to $d^{\prime}$ but with faint but continuous silty beds $1 / 2$ inch thick, $1 / 4$ inch and 2 inches from top; upper surface locally rippled (1936)

$h^{\prime}$. Soily material; dark brown, root-filled (pre-1936)........

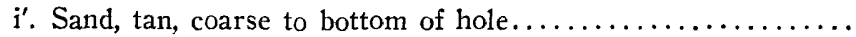

\section{Station MF 2}

[Bank of small brook near River Rd.; 0.4 mile NE. of French King Rock. See pl. 20,B. Approximate. distance below flood peak, March 1936, was 32 feet]

a. Silt, blue gray, clayey $(1938) \ldots \ldots \ldots \ldots \ldots \ldots \ldots \ldots \ldots \ldots \ldots \ldots \ldots \ldots .1$

b. Sand, faintly silty, chocolate brown, compact; bedding obscure (1938)

Inches

$2-3$

$c^{\prime}$. Silt, bluish to purplish gray, very compact; zone of $1 / 4$-inch sand lenses 1 inch from top; slightly sandy near base (1938)

d. Sand, silty, buff to tan; rich in leaves; faintly bedded; len-

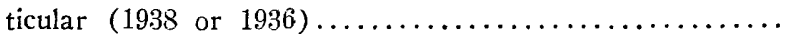

e. Silt, buff to olive gray, fine, sandy near top (1936) ........

f. Silt, purplish gray, very compact; bedding obscure (1936)..

g. Similar to $f$, but slightly coarser and locally rich in leaf and twig material $(1936) \ldots \ldots \ldots \ldots \ldots \ldots \ldots \ldots \ldots \ldots \ldots \ldots \ldots \ldots \ldots$.

h. Sand, white to gray, medium to coarse, evenly bedded; thin $\tan$ oxidized zone at top $(1936) \ldots \ldots \ldots \ldots \ldots \ldots \ldots \ldots$

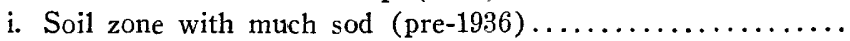

j. Silt, fine, compact, homogeneous; mottled brown; purplish in

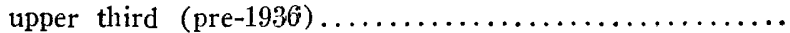

k. Sand, coarse, iron-stained, and silt, clayey, blue gray, alternating in beds $1 / 2$ inch to 2 inches thick; to bottom of hole (pre-1936)

Wherever possible a river or stream bank was stripped with a spade to expose the fresh flood sediments, but where the sediments lay on flatter surfaces, a hole approximately 2 feet square was dug to a depth governed by the thickness of the flood deposits or by the position of the local water table. The sediments on two adjacent faces of the hole were trimmed with a large knife to make their structural details more apparent. (See pl. 2o.) Wherever possible, each sample was collected 


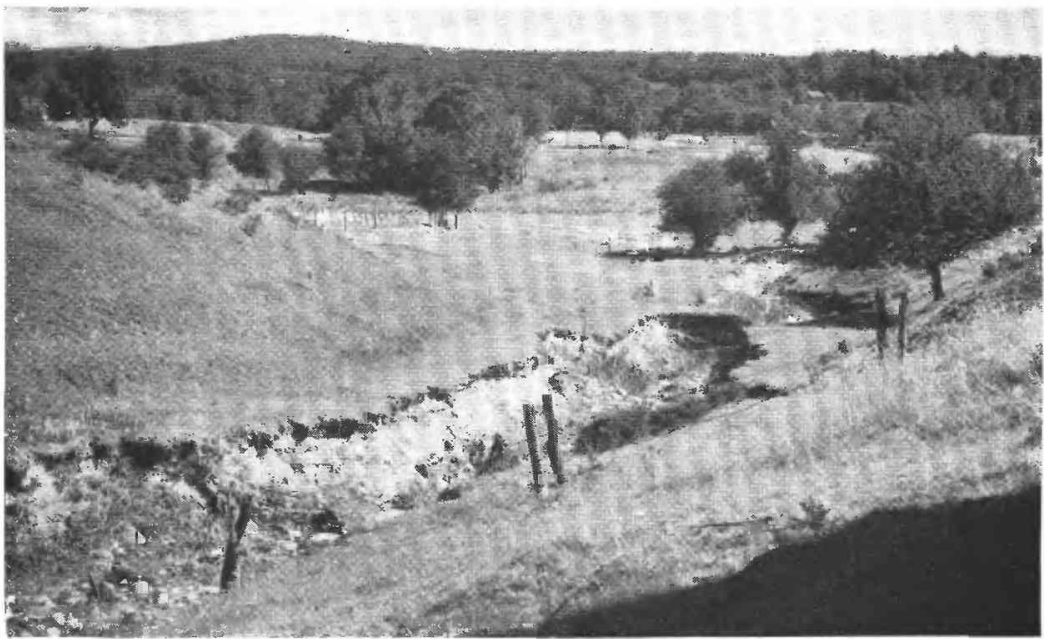

A. STRONG EROSION IN LOWER END OF SOD-COVERED VALLEY.

Apex of fan at far end of gully near the two trees.

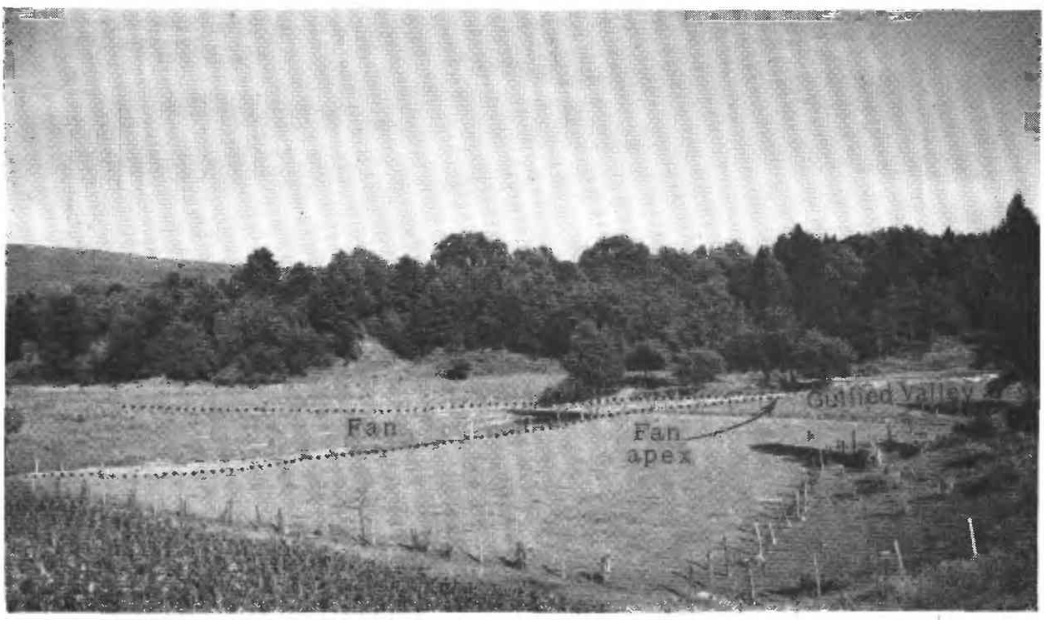

B. LOWER END OF SAME VALLEY.

Gully at right, debris fan at left.

RECENT GULLY AND FAN DEVELOPMENT WEST OF MONTAGUE. 

samples were generally well sorted, the three-fold division for the triangles was made about the rather small very fine sand group. Very fine sand is either abundant or dominant in nearly every analyzed sample; hence the grouping of sizes into three divisions of $<50$ microns, 50 to Ioo microns, and $>$ I00 microns in the triangular diagrams serves to emphasize textural differences that are not readily apparent in ordinary cumulative curves. Further, a diagram in which a point illustrates certain characteristics of a given unit permits the plotting, comparison, and ready interpretation of those characteristics for a great many units. Points near the very fine sand corner of the triangles represent materials that are very well sorted, whereas those representing more poorly sorted materials lie near the center or near the right hand edge of the triangle, because they thus include considerable amounts of the two end groups or of all three size groups.

\section{MATERIALS IN THE DEPOSITS}

SILT

The silty phases of the flood deposits vary greatly in appearance, but they are everywhere darker in color than the coarser, sandy beds. When moist, the firie silts are pearl gray, greenish or bluish gray, and dark grayish brown; when dry they are a very light gray to buff. Similarly, the coarser silts are chocolate brown, tan, and buff when moist, iight gray or buff when dry. Bedding is best in the coarser phases, and is generally thin and regular. The silt is the finest-grained material found in the deposits of the Connecticut Valley, and as such is the most coherent in any given flood section. Where it is the last-formed member of a deposit, it is commonly a dark, greasy-appearing, deeply mud cracked coating over those areas in which it has not been disturbed.

These silty constituents are markedly similar to the finer flood materials described from the Ohio Valley by Mansfield. ${ }^{83}$ They can be cut into smooth-sided blocks and are very sectile, although generally coarser than the distinctly clayey Ohio River deposits. A preliminary examination under the microscopic showed their chief constituents to be quartz. feldspar, garnet, hornblende, muscovite and biotite, magnetite, and several other opaque minerals. In addition, tiny fragments of fine-grained metamorphic rocks are present. Nearly all samples examined and tested were entirely noncalcareous. Clay minerals occur in very small amounts, but organic materials are rather abundant.

In many places below their surfaces, the silty deposits are mottled with small, irregular brown stains. These stains form around dead roots and worm burrows, and appear to be genetically analogous to the brown-stained surfaces of the deposits, as well as to similar stains on the

83 Mansfield, G. R., op. cit., pp. 701-702, 1938. 
outer surfaces of mud cracks. Mansfield ${ }^{84}$ has described similar features from the' Ohio Valley and has suggested that the deposits probably contained ferric iron as they were laid down, and that the iron was first reduced to the ferrous state by organic matter within the sediments, then reoxidized on exposure to the air. This explanation seems adequate for the Connecticut Valley occurrences. The partial analyses $I$ and 2 in table II represent the oxidized and unoxidized portions, respectively, of a flood silt from a bank of Cranberry Pond Brook, north of Sunderland. The samples were dried at room temperature before they were analyzed, so that most of the ignition loss is attributable to organic material and its contained water. It seems safe to assume that this organic material together with that already present on the depositional surface reduced the ferric iron in the fresh flood silt, which, according to reports, was reddish brown to brownish gray when it was first laid down. Local reoxidation resulted from admission of air to the mass through mud cracks and other openings, and seems to have been accompanied by an appreciable amount of leaching, as shown by the relative amounts of total iron in materials I and 2. Both were taken from the same sample.

TABLE 11.-Partial chemical analyses of flood sediments and associated materials from Connecticut Valley, Mass.

[R. E. Stevens, analyst]

\begin{tabular}{|c|c|c|c|c|c|}
\hline . & 1 & 2 & 3 & 4 & 5 \\
\hline $\mathrm{Fe}_{2} \mathrm{O}_{2}{ }^{1} \ldots \ldots \ldots \ldots \ldots \ldots \ldots \ldots \ldots \ldots \ldots \ldots \ldots \ldots$ & 4.16 & 5.64 & 5.22 & .... & ... \\
\hline MnO........... & .13 & .18 & .08 & .... & ... \\
\hline Ignition loss.............. & 5.36 & 5.80 & 9.48 & 1.30 & 4.02 \\
\hline
\end{tabular}

1 Total iron as $\mathrm{Fe}_{2} \mathrm{O}_{3}$; in the presence of organic matter it is impossible to distinguish by ordinary analytical means between $\mathrm{FeO}$ and $\mathrm{Fe}_{2} \mathrm{O}_{3}$.

1. Fine, reddish-brown flood silt from iron-stained zone along mud crack; bank of Cranberry Fond Brook, 0.15 mile from mouth. (See map of $71 / 2$-minute Greenfield quadrangle.)

2. Fine, bluish-gray flood silt from unoxidized zone adjacent to 1 , above; bank of Cranberry Pond Brook, 0.15 mile from mouth. (See map of $7 \frac{1}{2}$-minute Greenfield quadrangle.)

3. Soily material from terrace edge 2 feet above 1936 flood line; 0.1 mile south of Hockanum. (See map of Mount Holyoke quadrangle.)

4. Coarse gray flood sand, with local leaf and twig material; Fourmile Brook, near mouth. (See map of Millers Falls quadrangle.)

5. Coarse gray flood sand, with silty beds containing many leaves and twigs; mouth of brook 0.7 mile NNW. of fish hatchery, (See map of $71 / 2$-minute Greenfield quadrangle.)

\section{SAND AND GRAVEL}

The coarser phases of the flood deposits are mostly light gray or buff and loose textured. They are darker and more coherent, the greater the silt content. Thin bedding, rapid-current cross lamination, and ripplemarked upper surfaces are commonly well developed. In addition, a pseudo cross lamination is present in many of the more silty sands, and

s4 Mansfield, G. R., op. cit., 1938. 
consists of streaks of heavy minerals deposited on the lee sides of current ripples as they move downstream. This feature is analogous to that exhibited by many beds in the lower flood-plain sequence of most terrace sections (pp. 45-48) and throws light on flood conditions common on the earlier Recent flood plains.

The flood sands consist predominantly of quartz, feldspar, and muscovite, with subordinate amounts of magnetite, hornblende, garnet, and other heavy minerals characteristic of igneous and metamorphic rocks. Pebbles and granules in the gravels, which are nowhere coarse, consist of silicic crystalline rocks, basic igneous rocks, schists of an intermediate composition, slate, and, less commonly, small flakes and grains of Triassic shale and sandstone. Such gravelly beds usually exhibit a texture similar to that of coffee grounds.

\section{VEGETABLE MATTER}

Many of the sandier beds in the recent flood sequence, particularly those near the river banks, contain remarkably large amounts of leaves, twigs, wood chips, plant stems and stalks, and root fragments. These vegetable materials locally make up 60 percent or more of a given bed, and give to it a dark-gray to chocolate-brown color. Where the wood chips and stem material are dominant they are more or less uniformly scattered throughout the deposit; where leaves are the principal vegetable constituents, they occur as thin, dense mats, which form prominent partings. Although such material is common at the tops of sections, where it presumably settled during the recessive stages of the floods, it is more often found at the bases of sand and sandy silt beds, a peculiar condition which demands an explanation.

The ponding effect of Connecticut River embayments during flood stages was augmented at several points along the lower reaches of small tributary streams by landslips and by debris-choked bridges and culverts. As the small streams discharged into the bodies of quieter water so formed, they dropped most of their suspended load as deltas. The foreset beds of these deltas contain much vegetable material. A section measured on the bank of a small brook northwest of Northfield Farms (Millers Falls quadrangle) is given below (table I2); it represents a typical deltal sequence laid down in a body of quiet water ponded by a clogged bridge and for a short time by the Connecticut River itself. Sediments containing many leaves and twigs are confined to the most recent flood deposits, and most of the earlier flood deposits seem to have been removed by scour. These 1938 deposits are potential sources of concentrated vegetable material, which probably will be swept into the Connecticut by the early-stage, underloaded waters of the brook during the next flood. They would be deposited with sand and silt in favorable positions during the early rising condition of the Connecticut at points on or near its banks, 
TABLE 12.-Section of flood deposits on bank of Fourmile Brook between River Road and Central Vermont Railroad, 0.2 mile northwest of Northfield Farms

a. Silt, clayey, blue gray; dries to white, powdery material; re-

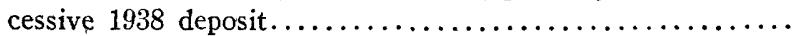

b. Sand, medium to coarse, light gray, cross-laminated; prominent 1 -inch twig, leaf, and stem zone at middle...........

c. Sand, silty, dark brown, very rich in vegetable material; oc-

curs as foreset beds ....................... $0-12$

d. Silt, clayey, bluish gray, compact and homogeneous; grades upward into $\mathrm{c}$; slightly sandy in lower half.............

e. Sand, light gray, matted compactly with leaves, wood fragments, stems, and twigs; locally silty; grades into d.....

f. Sand, light gray, very rich in leaves and stalks in lower half;

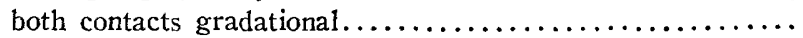

g. Sand, coarse, pebbly; bed-load deposit of 1938 flood?.......

h. Silt, clayey, compact; removed by scour in most places; recessive 1936 deposit?.............................

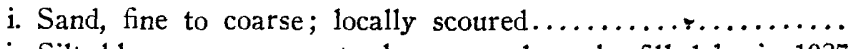

j. Silt, blue gray, compact, clayey; mud cracks filled by $i ; 1927$

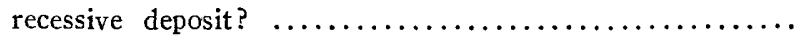

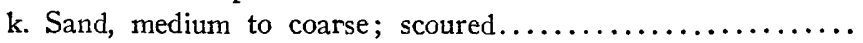

1. Silt, bluish gray, clayey, alternating in $1 / 8$ - to $1 / 2$-inch beds with sand, coarse; pre-1927 deposits?.................

Inches

$1 / 2$

$9 \pm$

$41 / 2$

$3 / 4$

$3 / 4 \pm$

$41 / 4$

$3 / 8 \pm$

$3 / 4-1$

$1 \pm$

$11 / 4 \pm$

10

and so weighted down with coarser material that they could not be carried away during subsequent higher stages. This general process, together with an early "cleaning up" of surficial vegetable materials by rising flood waters throughout the drainage basin, is thought to be responsible for the common occurrence of vegetable matter at or near the bases of flood sequences. A coarse, gray sand with zones of leaf and twig material was sampled near the mouth of Fourmile Brook (Millers Falls quadrangle). Its low ignition loss, I.30 percent (table I I, analysis 4), probably indicates that the amount of organic material and its included water is considerably less in these sediments than their appearance would suggest. A coarse sand, rich in vegetable matter, from the mouth of a small brook north-northwest of the fish hatchery (see table Io, analysis $5 ;$ pl. Io, $I$; and $7 / 2$-minute Greenfield quadrangle) was found to contain 4.02 percent of material lost by ignition, and the results obtained from analyses of finer sediments containing vegetable matter (table II, analyses I and 2) are of the same order of magnitude. A sample of soil derived from flood-plain sediments o.I mile south of Hockanum (Mount Holyoke quadrangle), on the other hand, is apparently much richer in organic constituents, a feature that is scarcely surprising because of its noteworthy content of roots and plant remains.

\section{MUD LUMPS}

Although homogeneity of texture is an outstanding characteristic of each bed in the flood deposits, a few exceptional occurrences have been 
noted. Wherever mud-cracked silts have been disturbed by subsequent flood waters, irregular chunks as large as 4 inches in diameter are commonly incorporated in the overlying sediments, near their base. Where these chunks retain their original tabular form, their positions indicate an interesting competition between current and speed of sedimentation. Some of the silt blocks were pried up by the current but were buried by silt before they could be turned over; thus they are laid in a position of upstream imbrication. A few were observed standing on edge, but most show downstream imbrication, and have reached their present altitudes by sliding from their original positions, or by having been completely turned over by the force of the current before burial.

Other mud lumps have a manifestly different origin, and were introduced from sources topographically higher than their present positions. Most lumps of this type were derived from silty or soily material in an adjacent river bank by undercutting and slump. A few of those observed apparently had been rolled for appreciable distances, because they were armored $^{85}$ with tiny pebbles, sticks, twigs, and even small leaves. A I938 deposit near the base of the east bank of the Connecticut at the East Deerfield railroad bridge showed a mud lump of this type "armored" with a bottle cap and a piece of broken glass.

\section{OTHER MATERIALS}

Most of the materials not already described were probably transported largely as' bed load, but their close association with the suspended-load sediments is responsible for their inclusion here. These materials are commonly of local derivation, and therefore aid in tracing directions of currents, as well as in evaluating their transporting capacities. Large numbers of flowerpot fragments, for example, were traced from their source at a nursery south of Smiths Ferry Cemetery (Mount Holyoke quadrangle) to points as much as a mile downstream, and were found in deposits of both the 1936 and 1938 floods. They were also seen in large quantities in bedrock crevices on the opposite side of the river some distance downstream. Cinders and clinker fragments were similarly traced southward from the Boston and Albany Railroad yards in West Springfield, and from the Boston and Maine Railroad yards at East Deerfield.

\section{GENERAL FEATURES OF THE DEPOSITS}

THICKNESS

Although the thickness of the flood deposits varies within wide limits. certain systematic trends appear in spite of many local fluctuations in sedimentation conditions. Table I 3 summarizes information concerning thickness of the deposits laid down by the two most recent floods in five general environments, as well as over the flooded area as a whole. All

85 Bell, H. S., Armored mud balls-their origin, properties, and role in sedimentation: Jour. Geology, vol. 48, pp. 1-31, 1940. 
figures except those in the bottom row represent only those examined occurrences where detailed sections were measured, and therefore are not wholly representative of the entire inundated area. The extent to which this is true is seen from a comparison of the two bottom rows. The localities for detailed measurement were selected where the sections were

TABLE 13.-Comparative, thicknesses of recent flood deposits of the Connecticut River

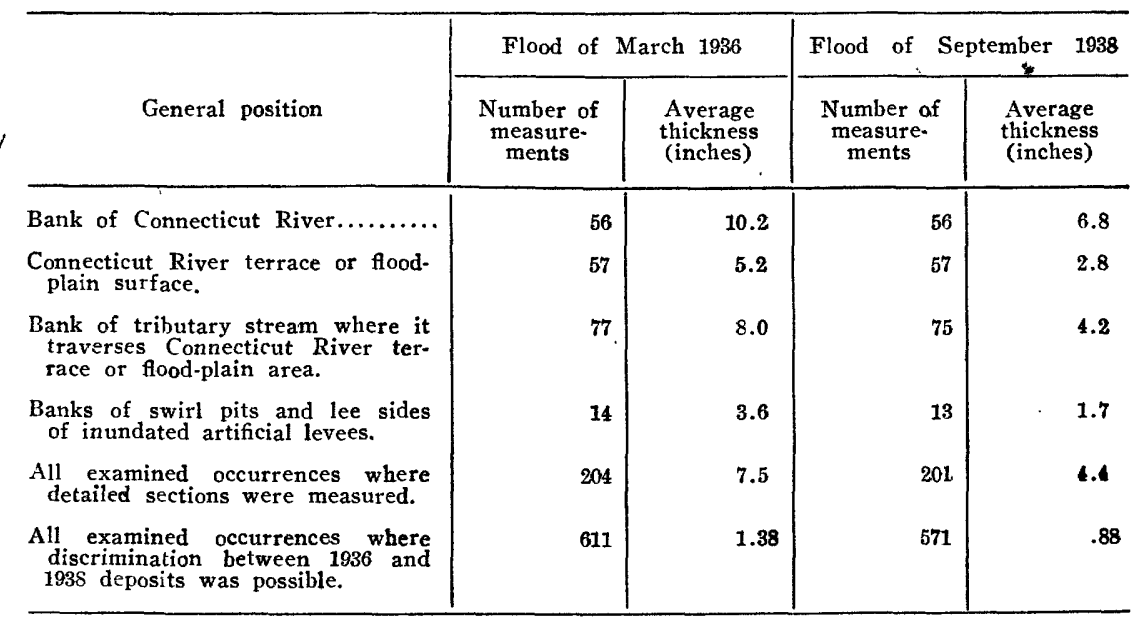

most complete, and the resulting preponderance of near-river localities thus furnishes a figure for average thickness (row 5 , next to the bottom) considerably greater than the true average. The many additional measurements from the intermediate and marginal portions of the flooded area, however, reduce these average figures to the smaller, more nearly representative values in the bottom row.

The deposits of the great flood of 1936 are considerably thicker than those of the 1938 flood. Not only is this true in general, but very few exceptions were noted. This is doubtless due to the greater discharge of the earlier flood, as well as its markedly longer duration. It is scarcely surprising that the maximum amount of material was deposited by the flood waters along the river banks, where the current was strongest, deposition of coarse sediment was most rapid, and the waters remained longest. The deposits are also thick on the sides of the small ravines cut by brooks, which cross the Connecticut River terraces and flood plains. Most of the ravines lay across the direction of flood current and acted as traps, receiving considerable amounts of sediment.

The thickness of flood materials is more variable on the meadows than in any other depositional environment. Because conditions there were nearer competence ${ }^{\varepsilon \boldsymbol{6}}$ than they were in the normal stream channel, the

${ }^{86} \mathrm{As}$ here used, competence is the limiting condition or conditions of volume, velocity, gradient, debris size, and channel shape, taken either singly or together, below which transportation will not take place. 
capacity of the floodwaters became very sensitive to the undulations and it regularities of their surfaces, and deposition was correspondingly more irregular. According to Gilbert, ${ }^{87}$ sensitivity of capacity to changes in the conditions that control it is greater when the conditions are near competence than when they are far above competence. Although the conditions in the small ravines were even nearer competence than those on the meadow surfaces, the factors affecting capacity in the ravines were far more regular. Deposits on meadow surfaces are thicker than those on the walls of swirl-pit areas, because in the latter much of the flood period was spent in erosive, rather than in depositional activity. Similarly, deposition on the lee sides of artificial levees did not take place until the levees were overtopped, hence the sediments there are relatively thin.

\section{MECHANICAL COMPOSITION}

Results of the mechanical analyses of the flood sediments have been plotted on the triangular diagrams of plate $2 \mathrm{I}$ and as cumulative curves on plate 26. It may be stated at the outset that the Connecticut Valley flood deposits are well sorted to a surprising extent for sediments of such rapid deposition. No layers containing material finer than silt and exceedingly few with fractions coarser than medium sand were observed in suspended-load sections. Plate 2I, $A$ shows the mechanical composition of representative deposits laid down by the 1936 flood; deposits of the I938 flood appear on plate $21, B$. Although these are slightly less well sorted and include several finer deposits, the two groups are strikingly similar. This is in close agreement with their appearance in the field. Both are considerably coarser, on the whole, than the composites of the Ohio and Potomac River flood deposits described by Mansfield. ${ }^{88}$ This is in keeping with the differences in profiles of the two rivers. (See pl. 7.) The Ohio and Potomac deposits are more poorly sorted, a feature which may be due in large part, however, to the inherently poorer degree of sorting in fine sediments as directly interpreted from their positions within the arbitrarily defined standard size-classification scale.

Analyses of suspended-load deposits from the Deerfield River appear on plate $21, E$. Those taken from flood plains in the canyon section of the river are considerably coarser than those from the Deerfield Meadows area. The combined deposits from the two widely different environments show a distribution not unlike that of the Connecticut River deposits. Not enough analyses of Deerfield River samples are available, however, to justify an interpretation of this correspondence in distribution.

\footnotetext{
${ }^{87}$ Gilbert, G. K., Hydraulic-mining debris in the Sierra Nevada: U. S. Geol. Survey Prof. Paper 105, p. 26, 1917.

8 Mansfield, G. R., Flood deposits of the Ohio River, January-February, 1937, in Grover, N. C., and others, Floods of Ohio and Mississippi Rivers, January-February, 1937: U. S. Geol. Survey Water-Supply Paper 838, pl. 25, fig. 2,C, 1937.
} 


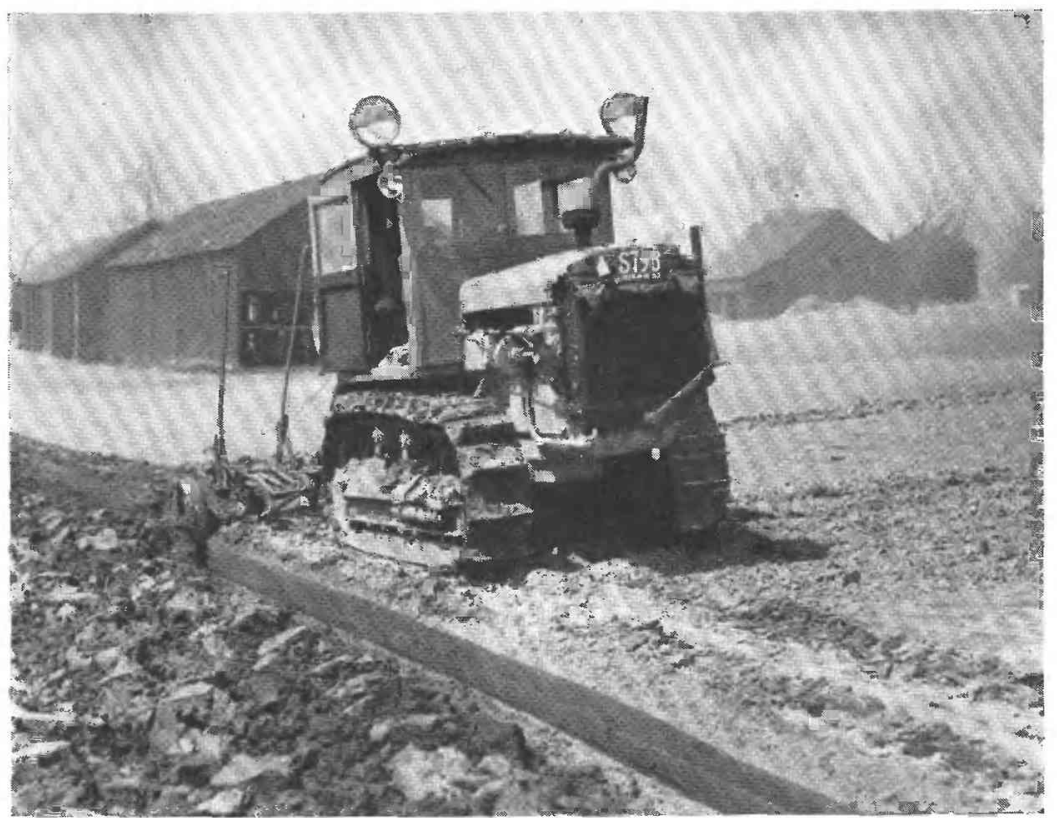

A. DEEP PLOWING CNDER OF COARSE MATERIAL DEPOSITED ON HIGH FLOOD PLAIN (IV). Note ripple-marked surface to right of tractor.

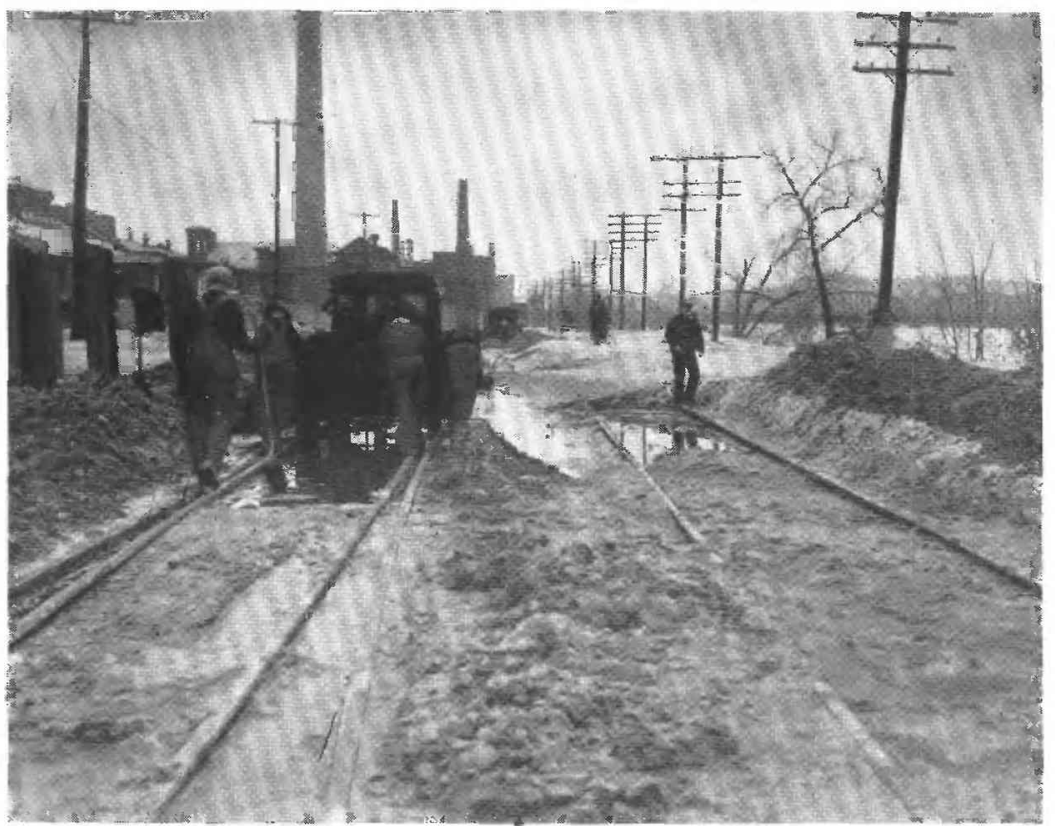

B. REMOVAL OF HEAVY SILT AND SAND DEPOSIT, HOLYOKE.

FLOOD SEDIMENTS NEAR CONNECTICUT RIVER, MARCH 1936.

Courtesy of Holyoke Daily Transeript-Telegram. 
4

- ${ }^{2} w^{2} x^{3}$

is th 


\section{SEDIMENTARY STRUCTURES}

The detailed structures of the individual flood materials have already been described, but some larger-scale features require further consideration. Bedding between layers of different material is commonly very sharp, especially in deposits on the banks of the Connecticut River and on the sides of ravines that cross the meadows. This is probably due in large part to rapidly changing conditions of channel flow as a result of the sudden occupation or quitting of nearby terraces or flood plains by the floodwaters. The neadows are so broad with respect to the relief of their surfaces that large areas can be completely flooded or abandoned with small changes in flood level. Also, the flood levels themselves characteristically change with great rapidity after occupying certain positions for appreciable lengths of time. (See pl. 15.) Local events also may be partly responsible for sharp changes in sedimentation in adjacent areas; most common of these are landslips, formation or sudden removal of debris dams, and channel shifts. Where the contact between two distinct layers is not sharp, the thickness of the gradational zone rarely exceeds half an inch, and is more commonly a quarter of an inch or less. Certain broad and faint textural gradations within thick layers are common, but the total differences involved are small.

The scouring of 1936 flood deposits by the waters of the 1938 flood was a process that contributed to the development of sharp contacts between layers, although it seems to have been active to a considerable extent only along the banks of the river. Intraflood scour relations also have been observed, and evidently were brought about by sudden quickenings or directional changes of the currents.

The mud cracks so commonly developed in the more silty materials that cap the 1938 flood deposits tend to form large polygonal blocks whose surfaces are flat or slightly concave upward. Where the usual sandy silt is covered with a thin, finer layer, which may represent a deposit laid down during a recessive stage of the same flood or a later deposit of the I939 spring high water, the polygonal surfaces are more markedly concave. This is in agreement with Bradley's statement ${ }^{89}$ that the amount of curvature in such blocks varies directly with the grainsize gradient of the material involved. The great depth to which some of the mud cracks opened is very striking. In several localities near the mouths of small brooks in the Montague Meadows, for example, distinct openings with oxidized faces were seen to extend downward for more than to inches. The mud cracks cross various layers with little or no change in atittude, and at the mouth of Gunn Brook, 2.5 miles north-northeast of Sunderland, a well-defined set transects a sequence consisting, from top to bottom, of 2 inches of dark, clayey silt, 4 inches of fine, silt-free sand, and 3 inches of sandy silt. This testifies to the

\footnotetext{
${ }^{89}$ Bradley, W. H., Factors that determine the curvature of mud-cracked layers: Am, Jour.
} Sci., 5th ser., vol, 26, pp. 60-64, 1933. 
control exercised over the structure by the upper silt and its extension to the lower silt. The deep openings appear to be confined to areas not more than to feet above mean river level,.which suggests that their great depths may be due to repeated immersion of the sediments during high-water stages of the river, with subsequent drying and progressive downward development of cracks. Most of them do not seem to have been filled with silt during these immersions, probably because the Connecticut is not heavily laden with sediment in the Montague Meadows during ordinary high water, and perhaps because the cracks close partly when the surrounding silt is wet.

\section{CRITERIA FOR RECOGNITION AND DISCRIMINATION OF FLOOD DEPOSITS}

The recognition of sediments of recent flood origin in the Connecticut Valley is generally not difficult even after several years. The surface appearance of undisturbed sediments is very characteristic, as is their blanketlike distribution over all topographic irregularities in the flooded areas. The downward extent of such deposits, however, is commonly more difficult to determine, especially on meadow surfaces, where the textures of the underlying older flood-plain deposits may be little different from those of the very recent deposits. Where problems of this sort arise, positive confirmatory criteria for the location of the lower boundary of the late flood deposits are essential and must be applied before the deposits themselves can be interpreted.

The presence of naturally deposited broken glass, bottle caps, scrap iron, and other products of modern civilization in such questionable sediments constitutes proof that they were laid down within the past three centuries, and the nature of such foreign materials commonly can be used to narrow the age limits further. Determination of the extent of burial of tree trunks gives a minimum measure of the thickness of the recent sediments; similar determinations can be made locally on fence posts, barns, and other structures which acquired weathered or otherwise distinctive surfaces before partial burial. Such evidence is especially effective when supported by reliable statements of nearby residents or by photographs. Strong angular discordance between two sedimentary series commonly indicates recent flood deposition on river banks or on the sides of scoured areas (pl. 22,E); this is not an entirely effective criterion, because similar relations exist between many pairs of older beds in flood-plain and terrace sections, although they are confined almost entirely to the lower flood-plain sequence. Zones rich in leaves and twigs strongly suggest recent flood origin for the beds in which they occur, but should be employed in connection with other evidence if possible. In the same way, a much disturbed, flat-lying, loamy zone of uniform thickness immediately beneath a normal bed commonly indicates a horizon of ploughing or other cultivation. on the meadow surface, but this should be interpreted with caution. All these features 
have been used by the writer in his determinations of the downward extent of many recent flood sequences in the Connecticut Valley.

Before attempting to assign different beds in a given section to the floods responsible for their deposition, the investigator should familiarize himself with the time of occurrence, crest height, and duration of each recent flood. In this way it is possible to eliminate some of the floods from consideration if the deposits in question occur at places topographically higher than levels reached by their waters. It is also possible to make tentative correlations between durations of floods and relative thicknesses of deposits, and between crest heights and coarseness of deposits. Where sediments deposited by more than one flood are found in the same section, the following features are helpful in their discrimination:

1. Angular unconformities.

2. Scour relations.

3. Drift sand.

4. Mud cracks and ripple marks.

5. Footprints and wheel tracks.

6. Soil and sod zones.

7. Roots of growing plants.

8. Old root zones.

9. Zones rich in vegetable matter.

10. Plowed or cultivated zones.

11. Mud lumps.

12. Sharp sedimentary contacts.

13. Marked lithologic changes.

Angular unconformities, generally found on the faces of river banks or other sloping surfaces, are due to erosion of the older deposit in such a manner that the slope of its upper surface becomes discordant with the slope of the surface on which it was laid down. This erosion may occur during the end stages of the earlier flood, during the early stages of the later one, or at some time between the two. Such discordance is very rare, however, within deposits of a single flood, because the necessary broadly alternating periods of deposition and heavy erosion do not appear to have existed along the river banks. Structural and age relations in typical flood sections are shown on plate 22, $A$ and $D$. Relations between recent flood sediments and earlier flood-plain material are illustrated in $E$; the results of their respective mechanical analyses appear in plate $26, B$. Measured sections are included in table $\mathrm{I} 3$.

Where erosion of the type explained above was not great enough to alter the configuration of the surface materially, disconformable relations commonly exist between deposits of different floods and may be recognized by irregularity of contact or by the local removal of beds from the lower sequence. (See pls. 20,B, 22, $B$ and $D$.) Such scour phenomena, however, should be used as interflood criteria with reservation because 
minor erosive stages may be active during a single flood. Nevertheless, it is true that not many intraflood scour relations were observed. A flood sequence deposited on a river bank or on an exposed meadow surface is generally covered by wind-blown sand or by slumped and wind-sorted material. This "drift sand" is easily distinguished from its water-laid associates by its uniformity of grain size, its lack of structure, its blanketlike covering of irregularities in the surface of the flood sediments, and its irregular thickness. It is a positive indication of exposure of the underlying material to the atmosphere. Examples are shown on plate 22, $A$ and $D$.

Mud-cracked surfaces are also clear and important criteria of exposure to atmospheric conditions. They may be filled by drift sand or by later flood deposits, as illustrated on plate 22, $C$ and $D$. Ripple-marked surfaces of beds covered by deposits of an entirely different nature commonly indicate a boundary between deposits of different floods, but also can be caused by sudden changes in sedimentation during one flood. Footprints in flood deposits (pl. 22,E) are reasonably reliable criteria, especially where they are filled with material of an appreciably different appearance. See pl. 23,C.) This is also true of wheel tracks. Both, however, should be carefully distinguished from indentations made during floods by grounding pieces of wreckage. (See pl. 22,C.) Where plainly recognizable, soil and sod zones constitute clear evidence of subaerial conditions. (See pl. 22, $B$ and $D$, and corresponding measured sections in table I4.) This is also true of old root zones where truncated and overlain by the finely stratified flood sediments. Shallow-rooted bushes and trees furnish a very clear-cut means for determining age boundaries in flood deposits that bury the bases of such plants, as shown in plate 22,F. The roots that grow from the trunk or stalk into the deposits indicate by their relative degrees of development the position of the interflood boundaries within limits narrow enough to correlate these boundaries with specific lithologic contacts.

TABLE 14.-Sections shozring typical flood deposits

[Materials are those illustrated in pl. 22. See also pl. 26, $A$ and $B$ ]

Station SN 5

[W. bank of river; 0.1 mile $\mathrm{S}$. of Ashley Ave. bridge. Approximate distance below flood peak, March 1936, was 9 feet]

a. Silt, sandy, dark gray $(1939$ ?) $\ldots \ldots \ldots \ldots \ldots \ldots \ldots \ldots \ldots \ldots \ldots \ldots \ldots \ldots$ 1/2

b. Sand, silty, fine, light gray, much cross-laminated; locally

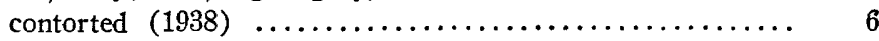

c. Sand, coarse, white, loose ; lenticular (post-1936, pre-1938).. $0-3 / 4$

d. Sand, fine light gray; thin-bedded, with silt zone at top (1936) 1-8

e. Silt, clayey, bluish, alternating in fine beds with sand, silty; very rich in rootlets; extends to bottom of hole (pre-1936) 10+ 
TABLE 14.-Sections shozving typical flood deposits-Continued

Station MH 17

[S. bank of creek, 3.0 miles W. of State Highway 13 bridge; 1.1 miles N. of Hadley. Approximate distance below flood peak, March 1936, was 13 feet]

Inches

a. Silt, clayey, blue gray, mottled with brown dots; more sandy

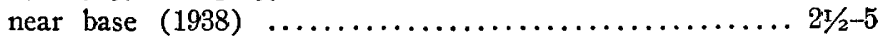

b. Silt, sandy, very thin bedded; locally removed by scour (1936) $0-11 / 2$

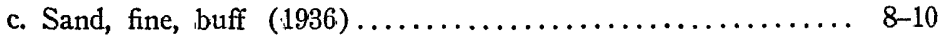

d. Soily material, dark, homogeneous, with large roots and vegetation zone at top; to bottom of hole (pre-1936)..... $7+$

\section{Station MT 12}

[E. bank of river; SW. corner of cemetery 0.6 mile SW. of Sunderland. Approximate dis. tance below flood peak, March 1936, was 8 feet]

Inches

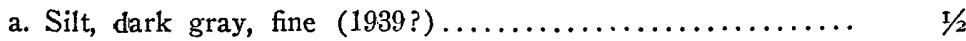

b. Sand, light gray, and silt, dark gray, finely interbedded; locally contorted by slump or.by grounding wreckage (1938) $1 / 2-21 / 2$

c. Sand, light gray, medium to fine, cross-laminated (1938) ... 1-5

d. Sand, gray, and silt, dark gray, finely interbedded; much leaf material; mud-cracked (1936) .................. $3 \pm$

e. Sand, medium to fine, light gray, locally cross-laminated; to

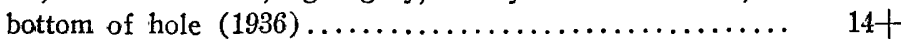

Station MF 4

[W. bank of river; end of Old Stacys Ferry Rd. Approximate distance below flood peak, March 1936, was 17 feet]

Inches

a. Sand, tan, silty, irregularly and finely bedded (1939?) . . . . 1/2-1

b. Silt, clayey, blue gray, compact $(1938) \ldots \ldots \ldots \ldots \ldots \ldots \ldots$

c. Silt, mottled, purplish brown $(1938) \ldots \ldots \ldots \ldots \ldots \ldots \ldots \ldots \ldots \ldots$

d. Sand, tan, fine-bedded, fills mud cracks in $f$ and $g$ (1938) .. 0-2

e. Sand, coarse, light gray, loose (post-1936, pre-1938) ...... 0-21/2

f. Silt, chocolate brown, clayey, lenticular (1936)......... 0-2

g. Sand, tan, silty, medium to fine, thin-bedded; locally ironstained; 1 inch zone of leaf material 3 inches from base

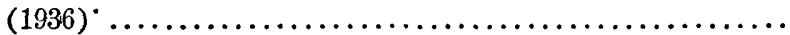

h. Silt, clayey, bluish gray to brown; zone of leaf material at top; grades into $g(1936) \ldots \ldots \ldots \ldots \ldots \ldots \ldots \ldots \ldots \ldots$

i. Silt, clayey, mottled, blue gray, interbedded with sand, fine, buff; well-defined sod zone at top (1927) .............

j. Clay, silty, compact, homogeneous, mottled brown, to bottom

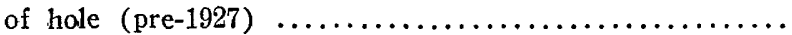

\section{Station MT 1}

[Edge of swirl pit in meadow area 0.8 mile NNE. of Hatfield. Approximate distance below flood peak, March 1936, was 7 feet]

Inches

a. Silt, dark gray; grades upward into lighter-colored, more

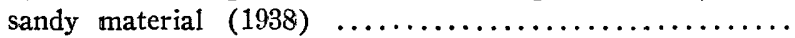

b. Sand, light gray, well bedded; local fine silty laminae (1938)

c. Silt, sandy, gray to buff; well bedded and locally cross-

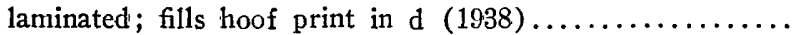

d. Sand, silty, well bedded, alternating with silt, gray, sandy; contains numerous clods of e (1936).................

e. Silt, sandy, buff, mottled tan to brown, little visible bedding, but contains horizontally oriented lenses of sandy material; .extends to bottom of hole (pre-1936) ............... 
Zones rieh in vegetable matter occur commonly at or near the base and at the top of a given flood sequence (pl. 22,D and corresponding measured section), but not consistently enough to serve as other than supporting evidence for more reliable criteria. Sharp sedimentary contacts and marked lithologic changes serve also as supporting rather than conclusive evidence, because they have been observed within the deposits of a single flood ( $\mathrm{pl} .20, A$ ), as well as at their upper and lower limits. Where the upper part of a sedimentary section on a meadow surface is greatly disturbed and churned to a uniform depth, cultivation is commonly the cause. If such a zone is covered by-later, stratified materials, its upper edge is the desired interflood contact. In a test hole near the south end of Bennetts Meadow (Northfield quadrangle), three distinct flood sequences were recognized by this feature and confirmed by other evidence in holes nearer the river. Mud lumps are eminently reliable criteria in distinguishing deposits of different age only where they can be identified with underlying material.

It seems evident from the foregoing discussion that some of the enumerated features are entirely reliable, whereas others should be used only as supporting or confirmatory evidence in the locations of boundaries between flood deposits of different ages. Most reliable are angular unconformities, drift sand, mud cracks, footprints and wheel tracks, soil and sod zones, root development of growing plants, old root zones, and mud lumps of known origin. Although some of these have been used as classic criteria in the interpretation of sedimentary structures, others are less well known but doubtless could be used in detailed studies of older river deposits.

\section{AGE-ENVIRONMENTAL RELATIONS}

The correlation of thickness and mechanical composition of flood deposits with the changing conditions under which they were laid down must be based upon a thorough study of the relations between the topography and the height and duration of each flood stage in each small area investigated. Observations have demonstrated that the widely and rapidly fluctuating conditions on flood-plain and terrace surfaces during floods, as well as the rarity of complete and undisturbed sections of flood sediment in those areas render them unsuitable for clearly tracing the depositional behavior of each flood. The banks of the Connecticut itself are'little better, partly because scour rendered many of the sections incomplete, and partly because it is very difficult in many places to assign deposits there to known floods. However, the small ravines that cross the meadows form traps of quiet water during flood stages and retain very complete and well-preserved sections whose beds delicately register the activity of the flood waters. In these ravines the depositional sequence for each flood truly reflects the height and duration of each of its different stages. 
The extraordinary flood conditions along the Connecticut River have been described on pages $55-57$ and illustrated on plate 8 . The approximate durations of the various river conditions during the 1936 and 1938 floods, as calculated from gage records in Montague City, are shown in table I 5. The ordinary spring high water of 1939 also was of sufficient duration to leave a significant depositional record. An inch or more of dark silt was laid down over areas adjacent to the river south of Holyoke (pl. 20,A), and smaller thicknesses upstream. (See pl. 22, $C$ and D.) Apparently this material was derived in part from the soft top layer of the 1938 flood sediments.

TABLE 15.-Relative duration of successive river conditions during extraordinary flood periods of March 1936 and September 1938

\begin{tabular}{|c|c|c|c|}
\hline \multirow{2}{*}{ Condition of river } & \multicolumn{3}{|c|}{ Approximate duration in hours } \\
\hline & Great flood 1936 & Hurricane flood & 1938 \\
\hline 1. High-water............... & 8 & & 24 \\
\hline 2. Rising.................... & 144 & & 20 \\
\hline 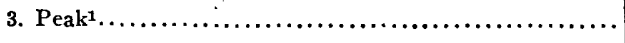 & 92 & & 25 \\
\hline 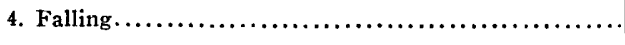 & 184 & & 64 \\
\hline 5. High:-water.................. & $360++$ & & 70 \\
\hline
\end{tabular}

1 Peak condition, as here used, includes not only the absolute maximum river stage, the peak stage as ordinarily used by the hydrologist and engineer, but the extraordinarily highwater stages immediately preceding and succeeding the maximum stage.

Figure 4 contains idealized columnar sections of typical flood deposits that would bè laid down in the tributary ravine nearest the observer on block A, plate 8 . Columns a to e correspond in location to points a to e, respectively, on the block. The sediments shown in the columns do not represent those found in any particular ravine in the Connecticut Valley, but are rather a composite of many obsefvations made in several ravines in the Northfield, Montague, Hadley-Hatfield, and Springfield-Willimanse:t Meadows. A brief reconstruction of the sedimentation conditions in this idealized area during the period 1936 to 1939 follows.

As a storm similar to that of March 1936 produces rapid and heavy runoff, the tributary stream is first affected, and lays down a deposit of sand $(F)$. As the Connecticut itself rises, sandy silt is deposited in its quiet-water embayment at $\mathrm{b}$ and $\mathrm{c}$, plate $8, A$. With continued rise to the high-water condition (pl. $8, B$ ), bank deposition involves a change to sand and silty sand, coarser sediments are deposited at point a by waters flowing across the low flood plain (V.), and point $\mathrm{c}$ is still receiving fine silt. These high-water deposits are thin because of the short duration of this general stage (table I4), and give way to those laid down under rising-stage conditions. (See pl. 8,C.) 
- Fine to coarse sand is dropped along the bank and at b. Sandy material is quickly deposited with silt at $\mathrm{c}$ by waters that now cover the high floodplain (IV), and d and e begin to receive quiet-water deposits. During this time the tributary has been contributing coarser material to the advancing embayment, which adds sand to the base of these quiet-water deposits. Its discharge, however, is now considerably less than it was when the early, coarse sand $(F)$ was laid down, inasmuch as runoff from its very small drainage area is decreasing. Sediments associated with the

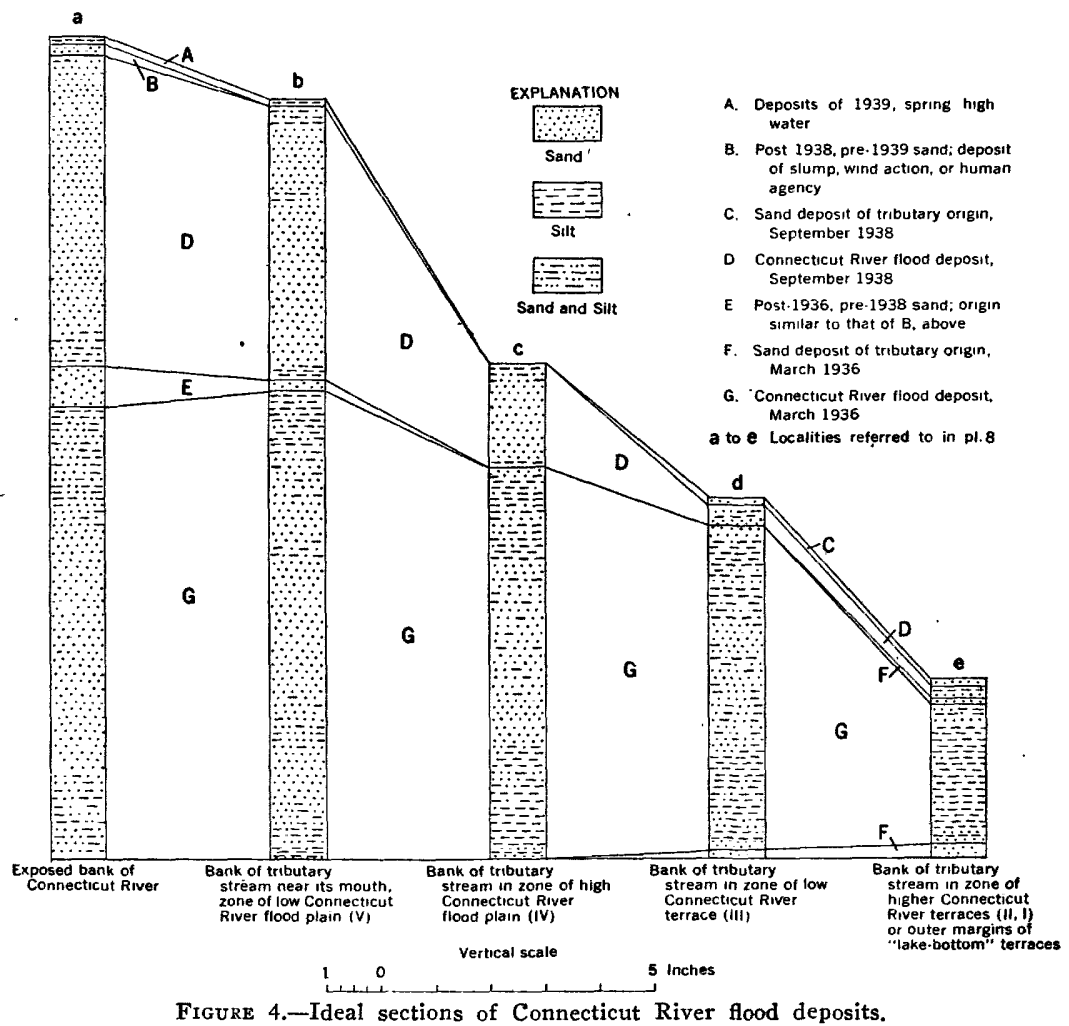

rising stages of the Connecticut River accumulate to considerable thicknesses, and pass into those characteristic of peak conditions (p1. 8,D) with merely a slight increase in coarseness, so far as points $a, b$, and c are concerned. At $d$ the silts are quickly covered with sandy deposits brought directly across the inundated low terrace (III) by the Connecticut flood waters, and at e the finer materials of the quiet-water embayment continue to accumulate.

This type of sedimentation persists until the waters recede to the falling, and longest-lasting condition. (See pl. 8,E.) Silt is received at e, but more slowly than before, the sandy materials at $d$ give way to silty ones, and sands and silty sands are dropped at $c$, where waters flowing 


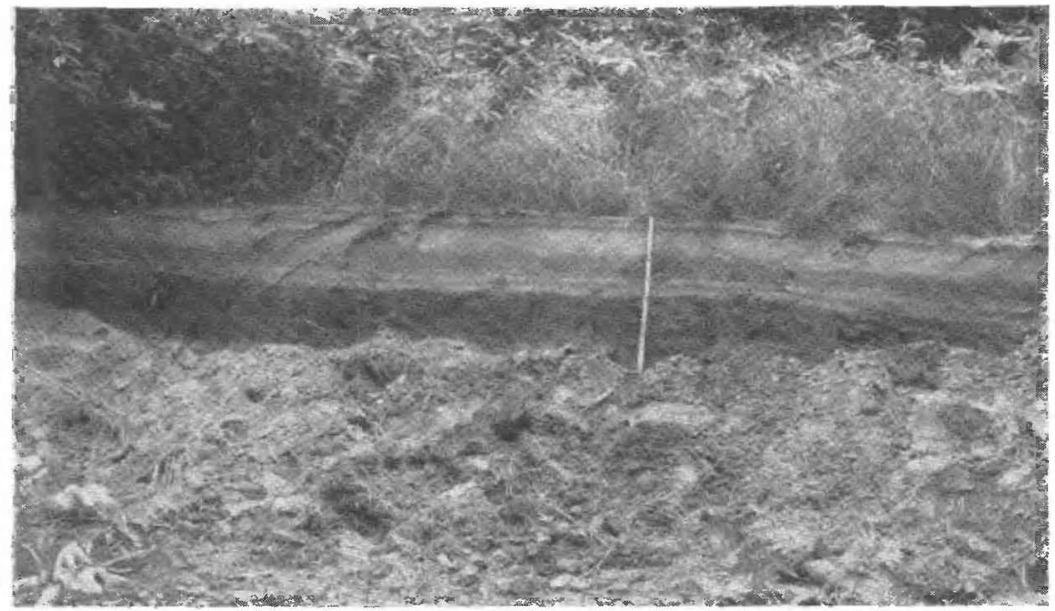

A. DETAIL OF BANK OF LOWER GOLDING BROOK, SOUTH OF HOLYUKE.

Upper half of section represents deposits of 1936 and 1938 floods and of 1939 spring high water. See table 10 for detailed descriptions.

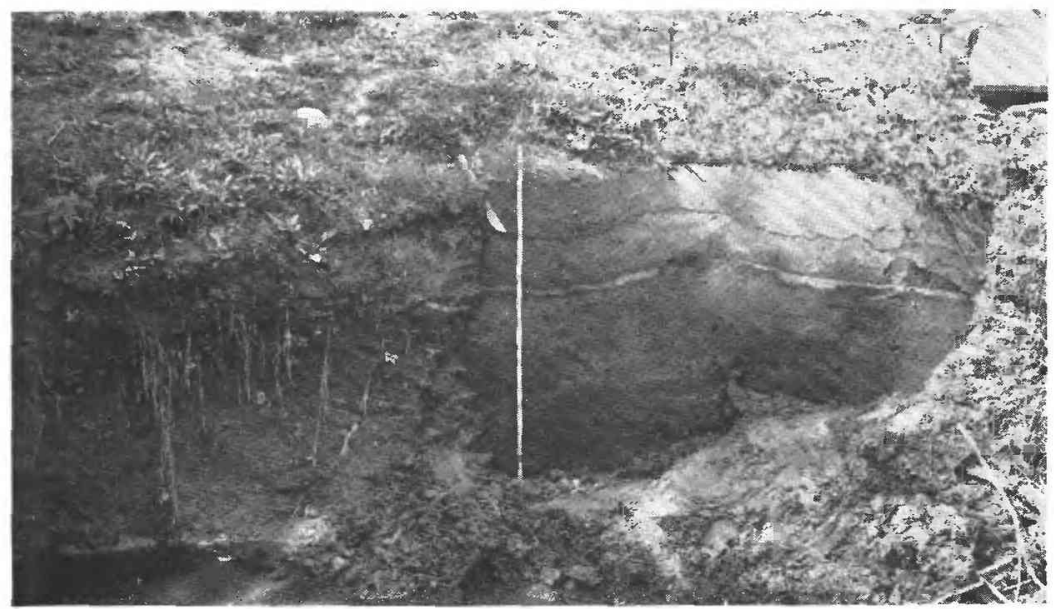

B. DETAIL OF BANK OF SMALL BROOK NORTH OF FRENCH KING ROGK, MILLERS FALLS QUADRANGLE.

Bank slopes toward observer. Thin, prominent sand layer and overlying sediments are recent flood deposits: lower tip of knife blade indicates contact hetween deposits of 1936 and 1938 floods. See table 10 for further details.

TYPICAL FLOOD DEPOSITS OF CONNECTICUT RIVER. 

across the high flood plain (IV) still pour over the ravine. Coarse sand deposition continues at $a$ and $b$. The retreating front of the embayment in the ravine is followed by slight sand deposition from the tributary stream, so that the tops of the quiet-water deposits are coarsened. As the river drops back to its ordinary highwater condition, the finer deposits are laid down at $a$ and $b$, but they are still dominantly sands. A recessive silt is now deposited at $c$, and embayment deposits are left above backwater level at $d$ and e, where the tributary stream is reworking them locally and adding sandy material of its own. The cycle is completed when mean river level is again reached. The total deposits of this flood (G, fig. 4) increase progressively in thickness downstream in the tributary ravine (from e to $b$ ), but are slightly thinner on the exposed bank at a than they are near the ravine mouth at $b$. This is due to removal of some of the bank material by scour during the flood, a process from which $b$ is safeguarded by its protected position.

Following recession of the floodwaters, wind-blown and slumped materials accumulate at $a$ and $b$ as drift sand. (See E, fig. 4.) This is the only important activity until later storms cause another flood cycle, in this case the hurricane flood. Return of a high-water condition causes sedimentation like that of the earlier flood, but the much shorter rising stages greatly reduce the thickness of fine deposits at the base of $c$ as compared with those of the earlier flood. Not only is the peak condition also of rather short duration, which restricts deposition of coarse material at $c$, but the crest itself is not high enough to cause much deposition of sandy sediment in the ravine at $d$ by waters flowing across the low terrace (III). The falling and second high-water conditions are both of shorter duration than the corresponding conditions of the earlier flood, so that thinner deposits are laid down at these times.

As compared with a flood of the 1936 magnitude, the net result of more rapidly fluctuating conditions in a flood of the 1938 type is to reduce the relative amounts of finer constituents at $a, b$, and $c$, and to reduce the total thicknesses of all deposits. As the floodwaters recede, the tributary brook forms the deposit $C$ (fig. 4 ), and a cover of drift sand ( $B$, fig. 4) is developed at a. Subsequent spring high waters, like those of I939, gather up and rework some of the sediment at the top of the preceding flood sequence, perhaps add a certain amount of material brought in from tributary areas, and deposit the whole as a thin cover of fine, dark silt (A, fig. 4) at a and b.

Many slight variations in conditions exist during the discharge of flood waters, even over very small areas. Hence no ravine traverse yields a section that reflects changing flood stages so completely as the composite just explained. However, actual sections do not differ greatly from the ideal composite. Thus the sequence of flood deposits in a small brook east of Deerfield was taken as a representative occurrence and studied in $689520-47-8$ 
considerable detail. (See pl. 24,A.) Its exact location is shown by the dotted line on plate $24, C$. The brook flows down a small ravine cut into bottom deposits of glacial Lake Montague, and drops over a steep bluff of Triassic shale before crossing a river terrace to join the Connecticut River. It follows a somewhat sinuous course on the floor of a small valley southwestward from the bedrock escarpment, but lies in a narrow ravine near its mouth.

A large part of the river-terrace area was covered by floodwaters in March 1936 and the entire valley shown in the sketch map (pl. 24,A) was flooded during the peak stage. This small area thus duplicates some of the important physiographic conditions shown on plate 8 , but the two flood-plain levels (IV and V) are absent. Detailed sections were measured and samples collected from nine stations (See pl. 24, sta 22, $A$ to 22,I.) Photographs of these flood-deposits sections appear on plate 23, the measured sections themselves are recorded in table 15 , and the results of mechanical analyses of selected samples are plotted on plates $24, B$ and $26, C$.

TABLE 16.-Sections showing typical flood deposits in small tributary stream northwest of fish hatchery (71/2-minute Greenficld quadrangle).

[See pl. 24, $A$ for detailed locations]

Station G22A

a. Silt, soily, with thin sod cover; scum of 1938 flood silt at top $(1936$ and 1938$) \ldots \ldots \ldots \ldots \ldots \ldots \ldots \ldots \ldots \ldots \ldots$

b. Silt, buff to tan, locally mottled brown (1936). (See pl. 26).

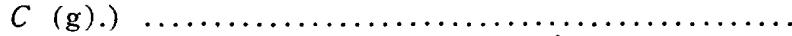

c. Soil, dark, with many roots; many fragments of Triassic

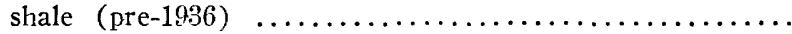

d. Rubble, tan, with many coarse shale fragments; extends to

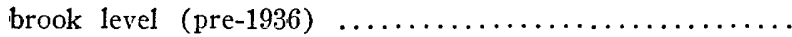

Inches

$$
1 / 4+
$$

$1-11 / 4$

$4 \pm$

$19+$

\section{Station G22B}

[See pl. 23,A]

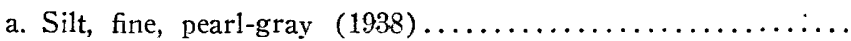

b. Sand, light grày, thinly bedded, with silt, dark (1938).......

c. Silt, sandy, bluish gray, faintly mottled; compact and homo-

geneous $(1936)$. (See pl. $26, C$ (h).).............. $31 / 2-4$

d. Soil, dark, with many rootlets (pre-1936)........... $21 / 2-4$

e. Sand, coarse, brown-stained, alternating in $1 / 2$ to $3 / 4$-inch beds

with silt, clayey; extends to brook level (pre-1936) ...... $17+$

Station G22C

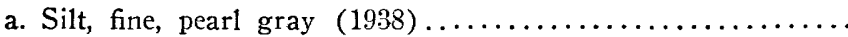

b. Sand, light gray, medium-grained; lenticular (1938).......

c. Silt, fine, light to bluish gray; fades upward into slightly coarser material; $1 / 2$-inch slightly sandy base (1936). (See

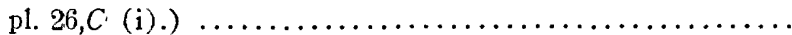

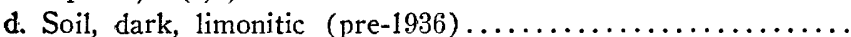

$1 / 8-3 / 16$

$1 / 4+$

e. Silt, fine, bluish gray (1927?) 
'ГABLE 16.-Sections shozeing typical flood deposits in small tributary stream northwest of fish hatchery (71/2-minute Greenfield quadrangle)-Continued

f. Soily material; dark, with many roots (pre-1927) .........

Inches

g. Sand, coarse, iron-stained, alternating in $1 / 4-$ to $1 \frac{1}{4}$-inch beds with silt, clayey to sandy; extends to brook level (pre-1927)

Station G22D

a. Silt, fine, light gray $(1938) \ldots \ldots \ldots \ldots \ldots \ldots \ldots \ldots \ldots \ldots \ldots \ldots \ldots \ldots \ldots$

b. Sand, medium to coarse, light gray to white; faintly iron

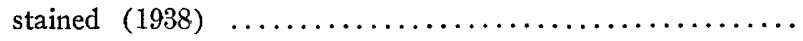

c. Silt, coarse, buff, very sandy at top and base; soil zone at

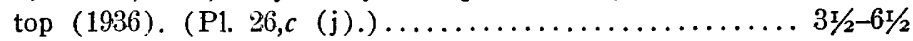

d. Silt, medium to fine, dark gray, compact, locally mottled;

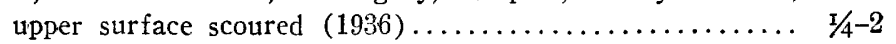

e. Soil, dark, iron-stained (pre-1936) $\ldots \ldots \ldots \ldots \ldots \ldots \ldots \ldots$.

f. Banded coarse sand and silt sequence, to brook level (pre1936)

$29+$

\section{Station G22E}

a. Silt, fine, bluish gray (1938)

b. Sand, silty, light gray to buff ; deposited around grass grow-

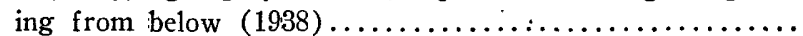

c. Silt, sandy, bluish gray, mottled brown, with soil zone at top; grades imperceptibly into d (1936). (See p1. 26,C (k).)..

d. Sand, fine, tan, micaceous, thinly bedded; local zones of leaf material; grades into e (1936). (See pl. $36, C$ (d).).....

e. Silt, very fine and clayey, bluish gray, mottled; $1 / 2$-inch sandy zone at base (tributary material?); sharply bounded at

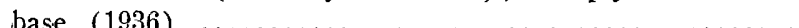

f. Soil, dark, ferruginous (pre-1936, post-1927) ...........

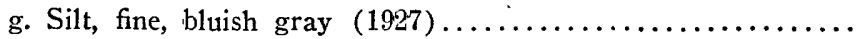

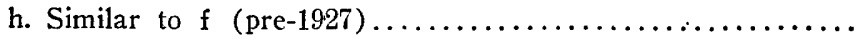

i. Banded coarse sand-silt sequence, to brook level.......... $16+$

\section{Station G22F}

[See pl. 23,C]

a. Silt, fine, dark gray, compact (1938)

b. Sand, light gray to white, loose, medium to coarse; local disturbed silty interbeds; fills hoof print in c (1938). (See

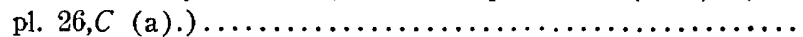

c. Soil, dark, with many roots $(1936) \ldots \ldots \ldots \ldots \ldots \ldots \ldots \ldots$

d. Sand, fine and brown, and silt, sandy, dark (1936)........

e. Sand, silty, chocolate brown; sharply bounded from f (1936).

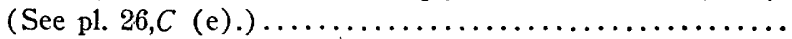

f. Silt, fine, buff to olive brown, mottled; sandy lenses in upper 2 in.; grades into mottled fine silt in lower $1 \frac{1}{2}-2$ in. (1936).

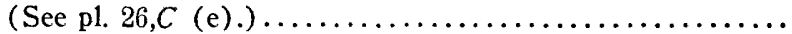

g. Sand, coarse, white, locally iron stained $(1927$ ?) $\ldots \ldots \ldots \ldots$ 1/2-2

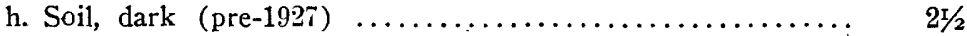

i. Banded, iron-stained coarse sand-silt sequence, to brook level $14+$ 
TABLE 16.-Sections showing typical flood deposits in small tributary stream northwest of fish hatchery (71/2-minute Greenfield quadrangle)-Continued

\section{Station G22G}

a. Silt, compact, fine, blue gray; local 1/16-inch crust of sandy

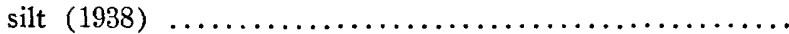

b. Sand, medium to fine, buff to dark brown, unevenly bedded, iron-stained; locally silty; very lenticular (1938).........

c. Silt, sandy, buff to dark brown, unevenly bedded; lenticular; strongly scoured and truncated by b $(1936) \ldots \ldots \ldots \ldots \ldots$

d. Silt, tan to buff with local patches of bluish gray; upper half very sandy and evenly bedded, with about $x / 4 \mathrm{in}$. bluish fine silt at top; lower half fine and very thin-bedded; all boundaries very gradational (1936). (P1. 26,C (m).).........

e. Silt; dark chocolate brown, compact; locally removed by scour

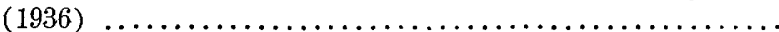

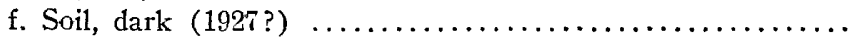

g. Silt, fine to sandy, bluish gray; sandy parts lenticular (19:7?)

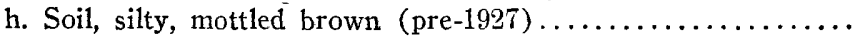

i. Banded, iron-stained coarse sand-silt sequence, to base of cut (pre-1927)

Inches

\section{Station
[See pl. $23, D]$}

a. Silt, fine, bluish gray to brown, broadly mottled; irregular sand lenses 4 inches from base (1938). (See pl. 26,C (b))

b. Sand, tan, thin and faintly bedded; local, poorly defined silty zones in upper 2 inches; lower $2 \mathrm{x} / 2$ inches finely and regularly banded, with more clayey beds toward base (1936).

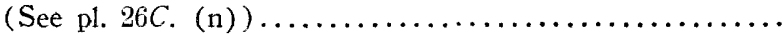

c. Silt, sandy, bluish gray, homogeneous, compact, locally iron-

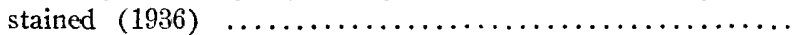

d. Soil, dark with many roots $(1927$ ? $) \ldots \ldots \ldots \ldots \ldots \ldots \ldots$

e. Silt, bluish, fine, mottled brown; faint $3 / 4$-inch sand zone near

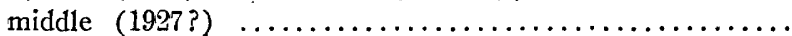

f. Silt, fine, brownish; no sand; apparently grades into e; con-

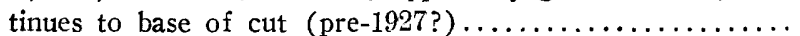

\section{Station G22I}

a. Sand, medium to coarse, interbedded with silt, sandy, with many twigs, leaves, and stalks; bedding very irregular and "wavy"; rapidly deposited sediments (1938). (See pl. 26,

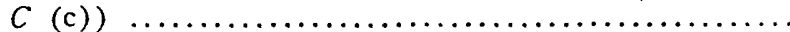

b. Sand, medium to coarse, light gray, interbedded with silt, sandy, dark gray, with many stalks, but not so many leaves; bedding irregular and "wavy"; extends to water level

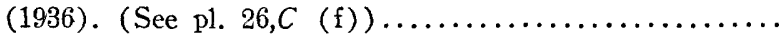

The dominant member in the' exposed sequences at points $22, B$ to $22, H$ (pl. 24; table I6) is a thick, compact, bluish-gray to tan silty sand, presumably a more or less quiet-water deposit of the I936 floodwaters. Its textural consistency is demonstrated by the close spacing of 
its cumulative curves ( $\mathrm{pl} .26, C$ ), although there is slight but systematic increase in coarseness toward the Connecticut River, a feature that is clearly evident in the triangular diagram, figure $19, B$. At station 22, $A$ (pl. 24; table I6), which corresponds to point e on plate 8, $A$, the total flood sediments are rather thin. Silt of the 1938 flood is merely a surficial scum. The 1936 deposit (pls. 22, $A(\mathrm{~b}), 24$; table 16), though thicker, has 'been partly reworked and "digested" into the underlying coarser material, hence its sorting is distinctly poorer than that of all the other deposits. At stations 22, $B$ and 22, $C$ deposition during both floods was of the quiet-water embayment type, and the thicker 1936 sediments become coarser at their tops and bases because of material contributed from the tributary stream itself. (See fig. 4,e.)

Peak-condition floodwaters that flowed directly across the low terrace were somewhat concentrated along its inner margin, and poured with great force across the tributary valley at point $22 \mathrm{D}$ (pl. 24,A), where they scoured some of the silts laid down in the quiet embayment waters of the immediately preceding rising stages. (See fig. 4,d.) The same general relations existed at the points downstream to $22, H$, although scour features are not so marked. Because the water on the low terrace was shallow during the 1938 flood, it concentrated in small depressions on the surface of the terrace, and so flowed into and across the tributary valley much more strongly at some places than at others. This is thought to be the explanation for the great textural variations in deposits of the 1938 peak stage from stations 22,D to 22,H: (See corresponding measured sections and the photographs in pl. 23.) At the mouth of the stream, station 22,I, the deposits are much coarser and more homogeneous than at any other observed place (fig. 4,a), and the sequences of the two floods are more nearly equal in thickness.

Further interest is added to these sections by the presence of deposits probably laid down during the flood of November 1927. (See p1. 23, $B$, $C$, and $D$.) They are comparable in thickness to the 1938 flood sediments, but appear to have been formed in quiet water, probably because the low terrace was not inundated. These older flood silts are overlain by about an inch of coarse, sandy deposits and underlain by considerable thicknesses of the same material, which is iron stained and distinctly banded. This material seems to represent deposits of the tributary stream. The excellent preservation and markedly finer texture of the 1927 flood deposits lead to the reasonable conclusion that absence of similar zones in the underlying tributary deposits probably indicates absence of great floods during the period of deposition of these deposits. It is significant that scarcely more than an inch of tributary deposits accumulated in the 9-year period I927-36. No Connecticut River flood reached point $22, C$, for example, during a period of at least 40 years prior to 1927 , because recognizable flood deposits are absent in a thick- 
ness of typical tributary deposits roughly corresponding to such a period. This is substantiated by the records. On the other hand, there is some evidence of earlier deposits at points $22, F$ and $22, G$, farther downstream, which may represent such earlier floods as those of 1922, 1909, 1902, I90 I, I895, or I894.

\section{EFFECTS OF ENVIRONMENT ON TEXTURES OF. DEPOSITS}

The flood samples have been divided into five general groups for purposes of comparison. Each group represents a broadly defined depositional environment. Environments so distinguished are river banks, flood-plain and terrace surfaces, embayments in small tributary valleys or ravines, flood-plain surfaces at mouths of large tributaries, and floodplain surfaces along the large tributary rivers themselves. The cumulative curves for nearly all samples are of the characteristic simple sigmoidal type, and very few show the two undulations toward the field of the finer particle sizes and toward that of the coarser sizes noted by Mansfield ${ }^{90}$ in the finer-textured Ohio Valley deposits. The rarity of this double hump in curves of the Connecticut Valley deposits supports Mansfield's suggestion that the feature may be due wholly or in large part to the arbitrary choice of 3 microns as a minimum size in the curves. The cumulative curves appear in plate 26 and data from them have been used in plotting points on the triangular diagrams of plate 25 .

\section{RIVER BANKS}

The flood deposits collected, from various points on river banks of straight or gently curving outline are remarkably uniform in texture. (See pl. 26,D.) Those of the 1936 flood are slightly coarser, on the whole, than those of the 1938 flood. Both are considerably coarser than flood deposits, sampled by Mansfield, ${ }^{91}$ on the banks of the Ohio River. (See pl. 25,A.) Samples from banks on the lee sides of river bends show much greater textural variations (pl. $26, E$ ), probably because of changing conditions of flow direction and turbulence during different flood stages. They are appreciably finer than those on straight banks because of their more sheltered positions. As on straight banks, however, the I938 deposits are finer, although only two samples of 1936 age are available for comparisons. All are much coarser than corresponding Ohio River samples. (See pl. 25,B.)

The outstanding difference between deposition at and slightly back from the edges of banks is shown by the curves in plate $26, F$. The samples from station MT 5 were taken from the north bank of the river on the lee side of the bend 0.7 mile north of North Hadley, the others (station MT 6) from a small flat to feet above mean river level and 20

${ }^{00}$ Mansfield, G. R., Flood deposits of the Ohio River, January-February, 1937, in Grover, N. C., and others, Floods of the Ohio and Mississippi Rivers, January-February, 1937: U. S. Geol. Survey Water-Supply Paper 838, pp. 729-730, 1938.

${ }^{21}$ Mansfield, G. R., op. cit., pl. 25, fig. 4A, 1938. 
feet from the bank edge. Table 16 contains corresponding measured sections. The curves show the marked textural differences between various samples that appear to be characteristic of lee-side bank deposition, and also demonstrate the greater coarseness of the materials at the edge of the river. Apparently those dropped on the small flat away from the river edge were carried by overflow currents sensibly weaker than the currents in the normal channel.

TABLE 17.-Sections showing flood deposits on lee side of rizer bend 0.7 mile north of North Hadley.

[See pl. 26, F]

Station MT 5 -

[N. bank of river. Approximate distance below flood peak, March 1936, was 26 feet]

a. Sand, loose, light gray; in part aeolian (1938) ...........

b. Silt, gray, sandy; contains much vegetable matter (1938)... 3

c. Sand, coarse, light gray, heavily cross-laminated (1938).... $4 \mathrm{t} / 2$

d. Sand, gray, and silt, tan to brown, finely interbedded (1938) $3 \mathrm{r} / 2$

e. Sand, dark, brownish gray, compact; locally well bedded

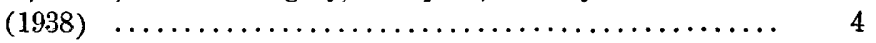

f. Sand, medium to coarse; much leaf and twig material (1938) $3 \mathrm{x} / 2$

g. Sand, light gray, grading downward into silt, dark gray, fine

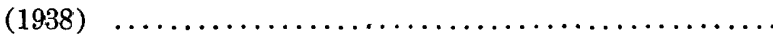

h. Sand, light gray, well bedded, at angular discordance with $g$

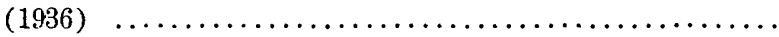

i. Sand, medium to coarse, cross-laminated; $1 / 4-$ to $1 / 2$-inch layers of leaves near base $(1936) \ldots \ldots \ldots \ldots \ldots \ldots \ldots . \ldots \ldots$

j. Silt, sandy, dark gray; compact, well bedded (1936)...... 11

k. Sand, coarse, light gray, alternating in 1- to 2 -inch beds with silt, clayey, blue-gray $(1936) \ldots \ldots \ldots \ldots \ldots \ldots \ldots \ldots \ldots$.

1. Sand, medium to coarse, locally iron stained; many leaves and twigs; extends to bottom of cut $(1936) \ldots \ldots \ldots \ldots \ldots 12+$

Station MT 6

[Small flat 10 feet above mean river level; 20 feet back from bank. Approximate distance below flood peak, March 1936, was 24 feet]

a. Silt, fine, dark (1938) ........................

b. Silt, dark gray, finely bedded; many leaves and twigs (1938) $7 \mathrm{~T} / 2$.

c. Sand, gray, and silt, brownish, finely interbedded (1938).... $21 / 4$

d. Silt, fine-bedded, compact sandy; grades into sand at base

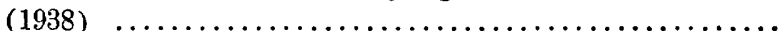

e. Silt, clayey; many roots $(1936) \ldots \ldots \ldots \ldots \ldots \ldots \ldots \ldots$

f. Sand, loose, gray, and silt, brownish $(1936) \ldots \ldots \ldots \ldots \ldots$

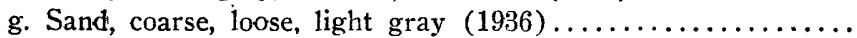

h. Silt, locally sandy, brownish; many leaves, stalks, and twigs

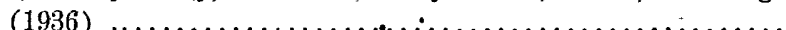

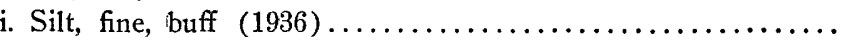

j. Sand, white, coarse, loose; lenticular $(1936) \ldots \ldots \ldots \ldots \ldots$

k. Silt, clayey, blue gray ; mottled brown $(1936) \ldots \ldots \ldots \ldots \ldots$

1. Sand, coarse, white, loose; grades downward into silt; extends to base of cut $(1936) \ldots \ldots \ldots \ldots \ldots \ldots \ldots \ldots \ldots \ldots, 6+$ 


\section{FLOOD-PLAIN AND TERRACE SURFACES}

Deposits on unscoured flood-plain and terrace areas adjacent to the river are distinctly finer than those along the banks. Furthermore, they are very uniform from place to place and are much better sorted. (See pls. 25, $C$ and $26, H$.) In general, those of the 1936 flood are coarser than those of the 1938 flood. The curves for deposits on meadows that show evidence of strong scour reflect the introduction of coarser material (pl. $26, \mathrm{G}$ ), and thus show poorer sorting. This is probably due to incorporated scoured material, as well as to contribution of sand by the strong scouring currents themselves.

Two well-defined groups of sediments exist on flood-plain and terrace surfaces more remote from the river. (See pls. 25,D and 26,I.) One consists of fine sand and silt of the type found on the riverward meadow surfaces, and the other consists of material considerably coarser. The finer type may represent rising- and falling-stage deposits, and the coarser those of the peak stages. Furthermore, a large proportion of sandy material was probably added to the flood sediments on outer marginal areas of flood plains and terraces by small tributary streams, whose deposits are known to be coarser than those of the Connecticut River itself. (See, for example, pl. 23.) These loads of tributary detritus presumably would be deposited over those parts of flooded meadow areas farthest from the main stream. The relatively better sorting of such marginal sediments with respect to those nearer the river, as noted in the Ohio Valley by Mansfield, ${ }^{92}$ is not a clearly recognizable feature of the Connecticut Valley.

\section{EMBAYMENTS IN SMALL TRIBUTARY RAVINES}

The flood sediments near the mouths of small tributary ravines (pl. $26, J-L$ ) have textural characteristics both of lee-side riverbank deposits and of flood-plain deposits. They vary appreciably from place to place like the riverbank deposits, and are well sorted like the flood-plain deposits. Although the 1936 materials are generally coarser, a few samples of 1938 flood sand are coarsest of all. This may mean that the large tributaries supplied coarser detritus to the Connecticut in 1938 than in 1936, because discharges along them were greater, and that the Connecticut deposited this coarser material on and near its banks during its peak stage. In addition to that contributed directly by waters crossing flooded meadows, much material laid down in the small tributary embayments probably drifts into them through the action of eddies. The comparative clarity of such embayment waters (pl. I I, $A$ ) suggests further that large amounts of material are possibly introduced from the much more turbid

\footnotetext{
92 Mansfield, G. R., op. cit., pp. 706-707, 1938.
} 
Connecticut channel by underflow of debris-charged waters, a process whose importance has been recognized in many places ${ }^{93^{\prime}}$.

A distinction in the curves has been made on the basis of locations of the simall tributary streams with respect to broad and narrow meadow areas along the Connecticut (pl. $26, J-L$ ). No important textural differences appear to exist between the sediments in such ravines in upriver, middle, or downriver parts of narrow meadow areas, but there is a suggestion of poorer sorting in ravines located in broad valley-bottom areas, such as the Hadley-Hatfield and Springfield-Willimansett Meadows areas. The addition of coarser constituents at such places is perhaps attributable to the currents that flow over the flood plains; these currents are much more powerful than those that flood the low terraces in the narrower valley-bottom areas, and are known to have lifted bed-load material onto flood-plain surfaces.

The coarser constituents are absent from deposits in tributary embayments at places more remote from their mouths ( $p l .26, M$ ), because during neither flood did such places receive sediment directly from flooded meadows. This is in contrast to areas nearer the river, where direct depcsition of materials of the type mentioned occurred at least during peak conditions. The silts and fine sands deposited in the back-water areas during such peak conditions are the textural equivalents of the deposits of the rising and falling conditions in parts of the same ravines nearer the Connecticut River. All such flood sediments in tributary ravines are compared in plate $25, E$ and $F$ with samples collected by Mansfield ${ }^{94}$ from somewhat similar situations in the Ohio Valley.

\section{FLOOD-PLAIN SURFACES AT MOUTHS OF LARGE TRIBUTARIES}

The low flood plain at the mouth of the Westfield River is normally 9 feet above mean river level. Mechanical analyses of flood sediments from this plain were plotted as cumulative curves; these appear in plate $26, N$ and correspond to certain members of the measured section at station $\mathrm{SS}_{3}$ in table 22. The deposits of the 1938 and 1936 floods are much coarser than those attributed to the 1927 flood, and are coarser than typical river-bank sediments, especially those in the Springfield-Willimansett Meadows. All are well sorted. The Chicopee River flows over a similar but smaller flood plain at its mouth, but samples were not collected there. The materials are coarser than those on adjacent Connecticut River banks and meadow surfaces.

\footnotetext{
B3 Barnes, F. F. Kraebel, C. J., and La Motte, R. S., Effect of accelerated erosion on silting in Morena Reservoir, San Diego County, Calif.: U. S. Dept. Agr. Tech. Bull. 639, pp. 7-8, 1939. Grover, N. C., and Howard, C. S., The passage of turbid water through Lake Mead: Amer. Soc. Civ. Eng. Proc., vol. 63, p. 64j-655, 1937. Fiock, L. R., Records of silt carried by the Rio Grande and its accumulation in Elephant Butte Reservoir: Am. Geophys. Union Trans., 15th Ann. Meeting, pt. 2, pp. 468-473, Nat. Research Council, 1934.

Mansfield, G. R., op. cit., pl. 25, 5, $A, 1938$.
} 


\section{TRIBUTARY RIVERS}

A sequence of flood deposits was examined on the north bank of the Fort River approximately 200 feet downstream from the Old Mill Pond dam. This area must have been the scene of unusual sedimentation from the waters flowing over the dam, because the deposits there are coarse and poorly sorted. (See pl. 26,O.) The relatively quiet waters of Old Mill Pond must have checked the transportation of coarse material before it could reach the dam, so that the coarse deposits below the dam are probably of very local origin. - These sediments were set in motion presumably by the underloaded waters pouring from the pond and were redeposited a hundred feet or more downstream as the waters lost much of their velocity and hence most of their capacity. A measured section of the deposits appears in table I8.

TABLE 18.-Section shozering flood deposits on bank of Fort River, 200 feet downstream from Old Mill Pond dam

[See pl. 26,O]

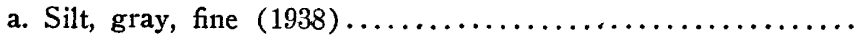

b. Sand, medium-grained, white, fairly compact (1938).......

c. Sand, light gray, coarse; local pea-sized pebble 'gravel zones

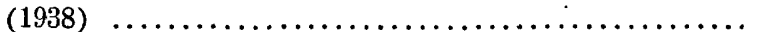

d. Silt, fine, well-bedded; somewhat lenticular; local zones with

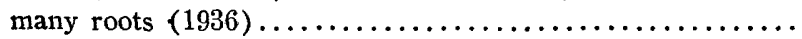

e. Sand, coarse, gravelly; poorly bedded; iron-stained in upper - 6 inches, white to light gray below; extends to bottom of

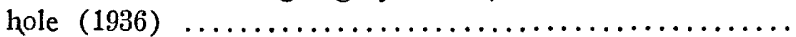

Inches

$1 / 8$ $1 / 2-3 / 4$ 7

$0-2$

$10+$

Plates $2 \mathrm{I}, C$ and $26, P$ show the textural characteristics of flood deposits taken from flood-plain surfaces along the Deerfield River. Superficially, the distribution of the curves is similar to that of curves for deposits on lee-side Connecticut River banks (pl. 26,E) and on meadow surfaces remote from the Connecticut River (pl. 26,I). This is due in part to the inclusion of samples a, b, and c (pl. 26,P), which were collected from the Deerfield Meadows (See pl. 3.) The others were obtained from the canyon area between Shelburne Falls and Zoar; they are moderately well sorted and their relative coarseness reflects the higher gradient of the river and of its flood plain. Measured sections from which the samples were collected are given in table I9.

TAELE 19.-Sections showing typical flood deposits from flood-plain areas along Deerfield River

[See pl. 26,P]

Station $G 29$

[Flood plain 0.7 mile SSW. of Deerfield; Deerfield Meadows]

a. Silt, clayey, light greenish gray, compact, very thin bedded,

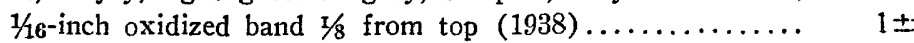


TABLE 19.-Sections showing typical fiood deposits from flood-plain areas along Deerfield River-Continued

b. Silt, fine, sticky when wet; scattered stalks and leaf fragments

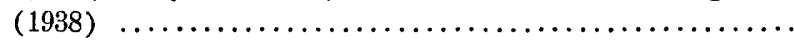

c. Similar to a, with sod zone at top containing many roots

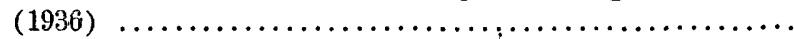

d. Silt, fine, compact, homogeneous; scattered leaves and stalks

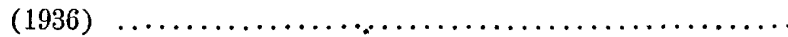

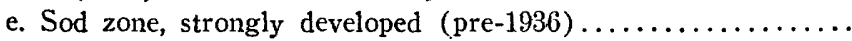

f. Soil, homogeneous, dark brown, sticky when wet; many rootlets; extends to bottom of hole (pre-1936)............

Inches

$31 / 4$

$r / 2 \pm$

$21 / 4$

$x / 2=$

$6+$

Station H 2

[Flood plain 1.4 miles WSW, of East Charlemont]

a. Silt, sandy, thinly and irregularly bedded (1938) $\ldots \ldots \ldots \ldots, 1 / 2-2$

b. Sand, medium to fine, tan, compact $(1938) \ldots \ldots \ldots \ldots \ldots .6$

c. Soil, dark, with sod zone at top (pre-1936?)........... 15/4

d. Silt, sandy, $\tan$ to brown, irregularly bedded (pre-1936) .... 15

e. Sand, buff to tan, medium to fine, compact ; extends to bottom of hole $\left(\right.$ pre-1936)............................ $7_{T}$

Station $\mathbf{H}$ 3

[Flood plain 0.7 mile $W$. of Charlemont]

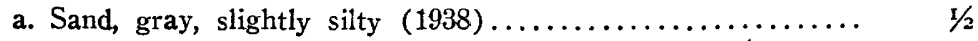

b. Sand, light gray, well bedded; rich in magnetite streak's (1938) 6

c. Soil, dark, capped by heavy sod zone $(1936) \ldots \ldots \ldots \ldots \ldots .2$

d. Silt, dark, sandy, compact; grades into e (1936).......... $3 \pm$

e. Sand, $\tan$ to brown, fine to coarse, extends to bottom of hole

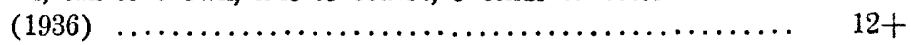

TABLE 20.-Section showing flood deposits at Station Wo2 in Westficld Meador's, near Tekoa Country Club, 1.5 miles west-northwest of Westficld

[See pl. 26, $Q$ ]

a. Sand, silty, tan to light brown, very micaceous (1938).... $3 / 4-2$

b. Similar to a, but purplish brown; grades irregularly into a

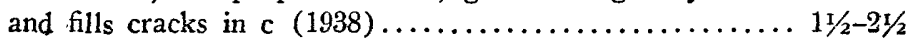

c. Sand, medium to fine, and silt, sandy; whole is purplish gray, sharply and finely bedded; light brown near base (1956)..

d. Soil, dark purplish brown; strongly developed sod zone at top; extends to bottom of hole (pre-1936)............ $7+$

A sequence of flood deposits in the Westfield Meadows near the Tekoa County Club (Woronoco quadrangle) was measured and sampled (Sec table 20 and pl. 26,Q.) Excepting a very slight admixture of coarse material, which may have been swept across the low meadow during a quickening in the flood current, the deposits consist of characteristic floodplain sediments so far as their texture is concerned.

\section{SUMMARY OF SUSPENDED-LOAD DEPOSITS}

Suspended-load deposits of the two most recent great floods in the Massachusetts portion of the Connecticut Valley are distributed over an area of $3^{8}$ square miles to an average depth of $2 \frac{1}{4}$ inches. They are 
thickest near the river and dwindle to mere films near the outer margins of the flooded area. The sediments that compose the deposits represent nearly all gradations from fine silt to medium sand; clay is not present. Leaves, twigs, stalks, and wood chips are common in the sandier materials, and are generally confined to horizons at the top, and at or near the base, of a given flood section. Artificial materials, such as broken glass and scrap iron, also occur in the deposits and confirm their flood origin.

Several criteria are valuable for discrimination of deposits laid down during different floods. The most reliable are angular unconformities, drift sand, mud cracks, footprints and wheel tracks, soil and sod zones, root development of certain growing plants, old root zones, and mud lumps of known origin. The thickness and texture of each member in a given flood sequence can be correlated with the height and duration of a definite period of the flood, especially in the deposits that occur in small tributary ravines that traverse meadow areas. Similar correlations in other depositional environments are possible, but the available sedimentary sections are rarely so complete.

In general, deposits of the 1936 flood are coarser than those of the 1938 flood. Both are best sorted on the outer margins of meadow areas and in the tributary ravines, and are coarsest on the river banks. Some systematic variations in texture with changes in depositional environments are of known occurrence, but are not of great magnitude. The flood deposits of large tributary rivers are appreciably coarser than those of corresponding age along the Connecticut.

\section{MATERIALS ASSOCIATED WITH THE FLOOD DEPOSITS}

The problem of determining the length of the period between the great flood of 1936 and the last flood of equal or greater magnitude is one of considerable engineering importance. The distribution and relations of recent flood deposits constitute one approach to the solution of this problem. As the Connecticut River has been progressively cutting downward and forming flood plains and terraces throughout postglacial time, its floodwaters in 1936 reached heights, as referred to given surface features, considerably lower than floods of equal discharge values did several thousand years ago. Hence, nearly all the materials that underlie the recent flood deposits are also of flood origin. To be sure, the sediments laid down in March I936, for example, lie directly on bedrock, till, and deposits of the late glacial sequence in several places, but such occurrences are of little significance. Bedrock and glacial deposits are exposed within reach of the river only in those places where the river itself has cut into them; the most recent flood deposits, therefore, will themselves be removed from such places in relatively short time. It thus becomes obvious that any critical sedimentary relations between 1936 
flood deposits and underlying materials will probably involve deposits of earlier floods.

Even though the materials underlying them may be of similar origin, the recent flood deposits commonly appear to be of markedly different nature. A careful study of the differences in the light of postglacial Connecticut River history has made possible an approximate evaluation of the minimum time gap represented by the contact between the recent and earlier deposits. Another avenue of approach relates to the materials above the levels reached by the 1936 and 1938 flood waters. If sediments similar to those laid down by the recent floods had been deposited at such higher levels in historic times, an earlier, higher flood would be indicated.

\section{DEPOSITS OF FLOOD-PLAIN ORIGIN}

Relatively young flood-plain deposits occur in the present flood plains; older ones in terraces. (See fig. 2.) The detailed sections of the low and intermediate terraces (III and II) that appear in tables 5 and 6, pp. $85-89$, show typical sedimentary sequences. Another excellent lowterrace section is that on the freshly eroded river bluff I.I miles south of Hadley (table 2I). Curves representing the mechanical analyses of selected samples are shown in figure $22 \mathrm{R}$. There is a clear-cut distinction between the sands of the bar and bottom and of the lower flood-plain sequences on the one hand, and the silty constituents of the lower and upper flood-plain sequences on the other. These silty constituents are closely grouped and are very well sorted, perhaps becat1se of their partly loessial origin; otherwise they are texturally like most of the recent flood deposits laid down on meadow surfaces. The bottom and bar sands are much coarser in texture, and are not from comparable depositional environments.

TABLE 21.-Section of sediments in eroded terrace front, east bank of Connecticut River, 1.1 miles south of Hadley

[Two points of measurement; B is 150 feet south of A. See pl. 26, $R$, for mechanical analyses and pl. $6, B$, for illustration of part of the section]

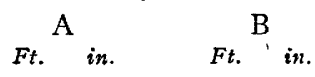

Post-1936 eolian veneer :

Sand, light gray, mdium to coarse; faintly bedded; in part eolian................

Flood deposit of peak stage, March 1936:

$41 / 2$

$13 / 4$

upper surface irregular................

Upper flood-plain sequence:

Soily silt, fine, structureless; upper 2 to 5 inches dark brownish gray, grading downward to a uniform tan............

Silt, texturally similar to material into which it grades upward; $\tan$ with reddish-brown mottles; structureless....... 
TABLE 21.-Section of sediments in eroded terrace front, east bank of Connecticut River, I.I miles south of Hadley-Continued

\begin{tabular}{|c|c|c|c|}
\hline \multicolumn{2}{|c|}{ A } & \multicolumn{2}{|c|}{ B } \\
\hline Ft. & $i n$ & Ft. & in. \\
\hline & 7 & & $75 / 2$ \\
\hline 2 & 2 & 1 & 9 \\
\hline 1 & $\begin{array}{r}11 / 2 \\
1 / 4\end{array}$ & 1 & $\begin{array}{r}61 / 4 \\
1 / 4\end{array}$ \\
\hline 1 & $\begin{array}{r}11 / 2 \\
1 / 2\end{array}$ & 1 & 0 \\
\hline & $113 / 4$ & & 11 \\
\hline & $31 / 2$ & & 3 \\
\hline 7 & 11 & 7 & 10 \\
\hline
\end{tabular}

Lower flood-plain sequence:

Sand, white, medium to coarse, evenly bedded; prominent ....................

Sand, white to gray, locally silty, alternating in thin beds with silt, fine, dark gray

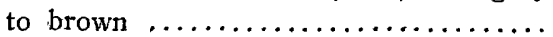

Sand, silty, dive brown to gray; sharply pseudo cross-laminated by heavy-mineral concentrates on lee sides of broad current

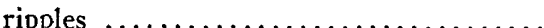

Sand, medium to coarse, horizontally bedded; white to buff; upper surface with current ripples $\ldots \ldots \ldots \ldots \ldots \ldots \ldots \ldots$.

Sand, fine, gray, very broadly rippled.....

Sand, silty, olive brown to gray; pseudo cross-laminated..$\ldots \ldots \ldots \ldots \ldots \ldots \ldots$.

Sand, medium to coarse, locally ripplemarked, alternating in $1 / 4$ - to 2 -inch beds with silt, fine, dark gray to $\tan . . . \ldots$. .

Sand, ripple-marked, locally contorted and iron-stained

Sand, medium to coarse, light gray to white, locally rippled and cross-laminated, alternating with silt, sandy, olive brown to buff. 
TABLE 21.-Section of sediments in eroded terrace froint, east bank of Connecticut River, I.I miles south of Hadley-Continucd
A
B
Ft. in.

Bottom and bar sequence:

Sand, loose, coarse, light gray; locally pebbly ; strongly cross-laminated, with topset beds absent; foreset zones 2 to 10 inches thick ..................... 10

\section{Glacial sequence :}

Clay, silty, varved, greenish to pinkish gray; many zones of "fat" and contorted material; extends to low-water level.......

\section{Total section to low-water level.... $34 \quad 73 / 4 \quad 34 \quad 11 \frac{1}{4}$}

A prominent, dark-gray, thin-bedded silty sand deposit of the 1936 Tod lies at the top of the upper flood-plain sequence in this terrace sec'ion. It is covered by coarse eolian sand, most of which is derived 'rom the loose bar and bottom sands near the base of the bluff. The food sand is a unique unit in the upper part of the section, and is dis"nctly coarser than any material in the top 5 feet of the upper floodplain sequence. Prior to 1940, it was present over a considerable area : $n$ a broad, low swale on the terrace surface. Rapid cutting of the bank Auring the spring high-water period of 1940 removed much of the 'iposit. Analogous occurrences, however; are common wherever the terrace III level (pl. 8) was inundated in 1936, and sections-are now xposed, notably immediately north and east of the swirl-pit area north of Hatfield and at the upper edge of small tributary ravines south and :outhwest of Sunderland.

The texture and position of the recent flood deposits at the tops of such sections suggest strongly that the 1936 flood was the only one to ' nundate those parts of the terrace surfaces extensively since the time they were active flood plains. To be sure, the 1938 flood also covered cortain portions of the low terraces, but not to any great degree; the critical places investigated were not quite reached by this flood. It might be argued that previous extraordinary floods may have left derosits that have since been removed by wind or water scour. Such a rquence of events is possible, but local traces or patches of the material should have been spared; detailed search on many exposed sections and in many test holes failed to reveal the faintest trace of such deposits. urthermore, some of the coarser beds laid down by the 1927 flood and carlier great floods are now well preserved in high flood-plain (pl. 8, IV) : actions. Had floods greater than that of 1936 occurred since cessation of ordinary flood-plain deposition on terrace III, similar traces of their i eposits night well be preserved there. 
It might be argued also that earlier flood deposits may have been incorporated and reworked into the upper flood-plain sequence so that they are now indistinguishable. It does not appear that this ever will be true of the 1936 sediments, because in many places they are considerably coarser than the very homogeneous underlying materials. Similar coarse deposits of past great floods are well preserved, and it seems probable than an earlier flood greater than that of 1936 would also deposit unusually coarse material in enough places on the low terrace surface to be recognized after a thorough search. Although cultivation might tend to destroy the identity of such material, many small, undisturbed meadow areas can be found. Finally, coarse eolian drift sand, so commonly present on the surfaces of the inundated low terraces, is absent from the underlying upper flood-plain sequence and thus also is unique in the record.

The analyses of selected samples from a terrace section adjacent to the swirl-pit area 0.6 mile west-northwest of North Hadley appear on plate $26, S$. Information concerning the position, thickness, and lithology of each sample is included in table 22. Figure 22, $T$ contains curves for all other flood-plain sediments sampled. Inasmuch as each sample came from a position immediately underlying recent flood deposits on meadow surfaces, only materials from the upper flood-plain sequence are represented. They are very well sorted and strictly similar in texture to most of those deposits of the 1936 and 1938 floods laid down on the riverward surfaces of present flood plains. Analyses of the samples of flood-plain and terrace deposits are represented in the triangular diagram of plate $27, A$, and show distinctly the excellent sorting that is characteristic of those deposits. Those of loessial origin are discriminated, and for the purpose of comparison, analyses of Ohio Valley loess ${ }^{95}$ are included.

TABLE 22.-Position and lithology of members of terrace section adjacent to szerirlpit area 0.6 mile WNW. of North Hadley

[See pl. $26, S$ ]

\begin{tabular}{|c|c|c|c|}
\hline $\begin{array}{l}\text { Sample } \\
\text { No. }\end{array}$ & Description of member & $\begin{array}{l}\text { Thickness } \\
\text { (inches) }\end{array}$ & $\begin{array}{c}\text { Distance of } \\
\text { upper edge } \\
\text { below surface } \\
\text { of terrace } \\
\text { (feet) }\end{array}$ \\
\hline MT $4 \mathrm{~d}$ & $\begin{array}{l}\text { Silt, in part loessial, tan to buff, structureless, fine } \\
\text { (upper flood-plain sequence). }\end{array}$ & 26 & 2 \\
\hline MT 4e & $\begin{array}{l}\text { Silt, sandy, gray to buff, locally iron-stained; bedding } \\
\text { indistinct (upper flood-plain sequence). }\end{array}$ & 7 & $41 / 6$ \\
\hline MT 4o & $\begin{array}{l}\text { Silt, sandy, gray to buff; locally very fine (lower } \\
\text { flood-plain sequence). }\end{array}$ & 10 & $61 / 3$ \\
\hline MT $4 k^{\prime}$ & $\begin{array}{l}\text { Sand, stained and cemented with iron and manganese } \\
\text { oxides; fine (bar and bottom sequence). }\end{array}$ & $x / 2$ & $10 \% / 2$ \\
\hline MT $4 o^{\prime}$ & $\begin{array}{l}\text { Sand, light gray, medium to coarse, local bands of } \\
\text { bluish silt; cross-laminated (bar and bottom sequence). }\end{array}$ & $14 \pm$ & $111 / 3$ \\
\hline
\end{tabular}

${ }_{05}$ Mansfield, G. R., op. cit., pl. 25, fig. 13, 1938. 

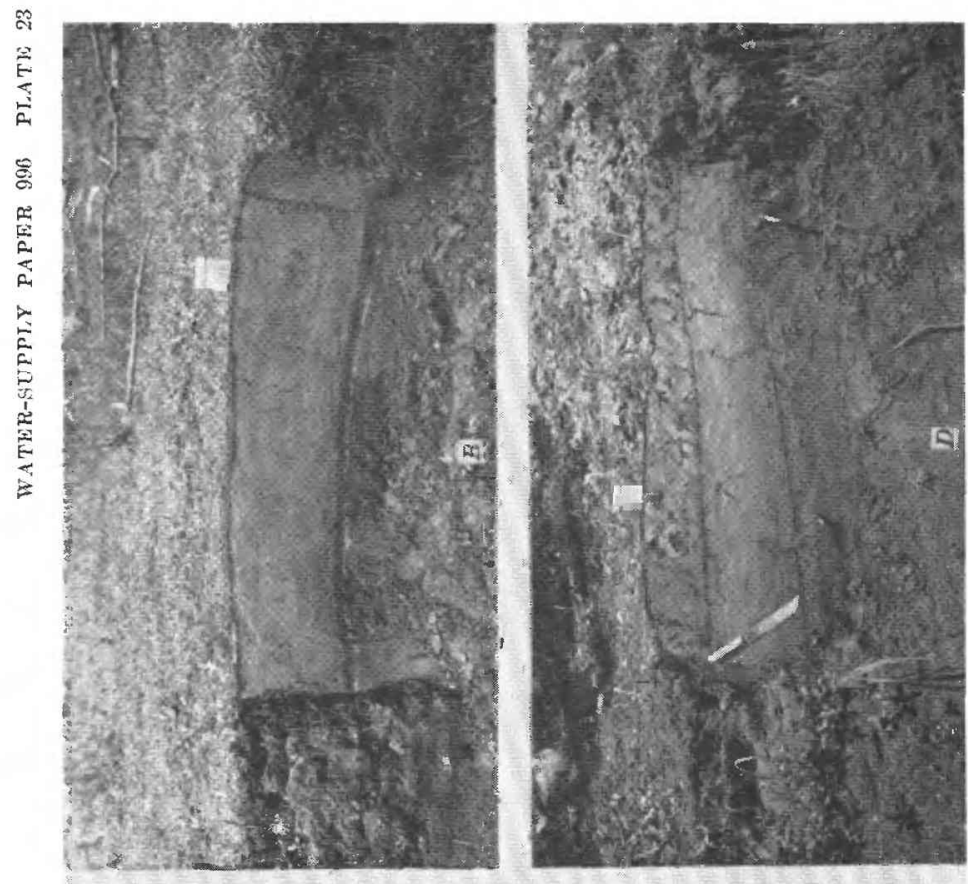

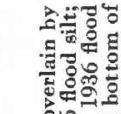

ㄷํ ซิ

乙 क्षे

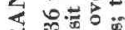

을융

造要卷

-

ค 류에

농

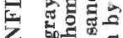

国 농

พ

다 कै

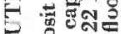

乙 헝유

我

त \&

ค ํㅐㅇㅢ

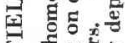

运

도 늘

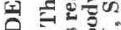

ค.:돈

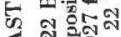

I 0 긴
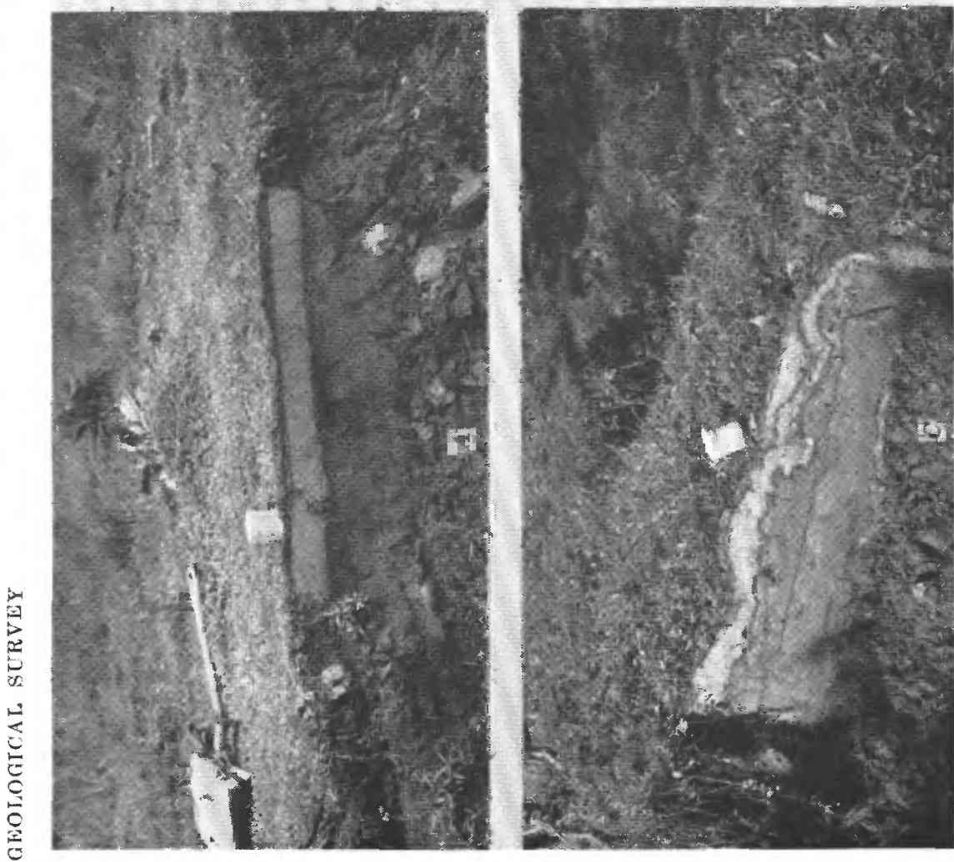

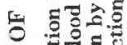

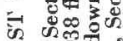

तi

5 b.

엉

田 오.

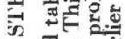

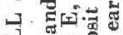

궈영

$\sum_{0}-0 \div$

का

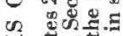

的的可

至

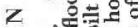

7 ह

क ज

जे

\& $3 \mathrm{i}^{2}$

舅

的的

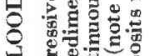

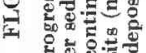

2.

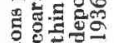
\%ั 



\section{DEPOSITS OF FLOODS OF PROBABLE OCCURRENCE DURING PAST 150 YEARS}

In many of the lower test holes nearer the river, deposits of earlier noteworthy floods were recognized beneath those of the 1936 flood. Some of these could be ascribed with reasonable assurance to the flood of November 1927 (pl. 23 and table I5), whereas others seemed to be older. The mechanical analyses of a few samples of such deposits are illustrated on plates $26, U$ and $27, B$ and show that the deposits differ little in texture from the majority of analyzed deposits of the recent floods. This is also true of their appearance in the field; structural criteria must be employed in order to distinguish them satisfactorily.

\section{DEPOSITS OF UNKNOWN OR DOUBTFUL ORIGIN}

The materials found beneath the 1936 flood deposits in many test holes did not lend themselves to ready identification, either because of their disturbed structure, because of their partial conversion to soil, or because of their totally unfamiliar appearance. Mechanical analyses of these materials (pls. $26, N, V, W$, and $27, C$ ), show that they are much more poorly sorted than those of the recent flood deposits. This is doubtless the result of reworking by roots, worms, cultivation, and similar agents, and of conversion to soil.

The sections measured at those localities where observed deposits of unknown or doubtful origin are overlain by recent flood sediments appear in table 23. SS $3 \mathrm{f}$ is a compact, root-filled hardpan found on a low flood plain at the mouth of the Westfield River beneath deposits corre-

TABLE 23.-Sections showing recent flood deposits in relation to underlying deposits of unknozen or doubtful origin

[See pls. $26, N, W$, and $27, C$ ]

\section{Station SS :}

[N. end of Big Island under transmission line; 0.1 mile from Connecticut River bank. Approximate distance below flood peak, March 1936, was 15 feet]

a. Sand, silty, buff to light gray $(1938) \ldots \ldots \ldots \ldots \ldots \ldots \ldots$

b. Sand, light gray, medium to coarse, faintly but horizontally

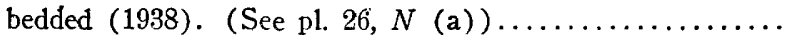

c. Sand, light gray, medium to coarse; many roots, with pronounced root zone.at top (1936). (See pl. 26, $N$ (b) )....

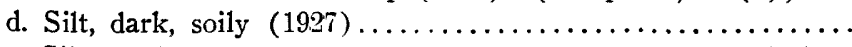

e. Silt, sandy, greenish gray, compact, homogeneous, faintly bed-

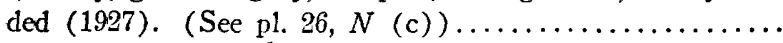

f. "Hardpan", silty, chocolate brown, very hard and compact, many roots; extends to bottom of hole. (See pl. $26, N$ (d))

Inches distance below flood peak, March 1936, was 8 feet]

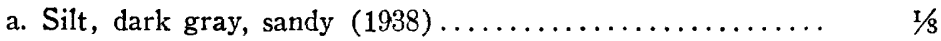

b. Sand, fine, gray, thin bedded; silty near base (1938) ...... 4

c. Silt, sandy, gray; sod zone at top; cracks filled by b (1936). $1 / 4$

d. Sand, medium-grained, light, locally with many rootlets (1936) $51 / 2$ $689520-47-9$ 
TABLE 23.-Sections shorcing recent flood deposits in relation to underlying deposits of unknowen or doublful origin-Continued

Inches

e. Silt, dark gray, sandy, alternating with much thicker beds of sand, fine, gray (pre-1936) .................. 1

f. Similar to e, with relatively thinner beds of sand (pre-1936) 11/2-2

g. Silt, soily, homogeneous : local traces of thin, regular bedding; dark at top, fading downward to tan; extends to bottom of hole

Station MH 2

[Flood-plain surface 0.3 mile S. of Hockanum. Approximate distance below ond peak, March 1936. was 28 feet]

a. Silt, clayey, bluish to brown; thinly banded (1938) ........

b. Sand, tan, medium to coarse, homogenous (1938?) .........

c. Silt, clayey, bluish gray, structureless; locally iron-stained along root holes; extends to bottom of hole.

Inches

$11 / 2$

$9 \mathrm{r} / 2 \pm$

$4+$

Station MH 4

[S. side of Bostion \& Maine RR. embankment; flood plain 0.7 mile W. of Hadley. Approximate distance below flood peak, March 1936, was 9 feet]

a. Sand, white, coarse, loose (1938) ..........................

b. Sand, tan, coarse, faintly silty $(1936) \ldots \ldots \ldots \ldots \ldots \ldots \ldots \ldots \ldots$

c. Loam, silty, dark; rich soil (pre-1936) ........... $8 \mathrm{r} / 2$

d. Silt, clayey, tan; local iron-stained spots; extends to bottom of hole $\ldots \ldots \ldots \ldots \ldots \ldots \ldots \ldots \ldots \ldots \ldots \ldots \ldots \ldots \ldots \ldots$

\section{Station MH 13}

[S. bank of Fort River at bridge near mouth. Approximate distance below flood peak, March 19.36, was 22 feet]

a. Silt, dark (1938)

Inches

b. Sand, medium to fine, light gray $(1938) \ldots \ldots \ldots \ldots \ldots \ldots$

c. Silt, sandy, gray; locally mottled brown (1938) ..........

d. Sand, tan to light gray; locally faintly silty $(1936) \ldots \ldots \ldots$

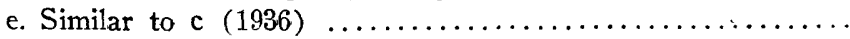

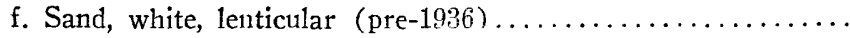

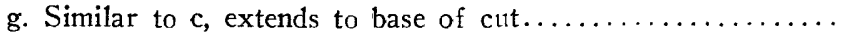

$1 / 8$

$1 / 2$

$51 / 2$

$13 / 4$

$3 \mathrm{~L} / 2$

$0-23 / 4$

$6+$

\section{Station MH 16}

[N. bank of Stony Brook near mouth; 30 feet upstream from highway bridge. distance below flood peak, March 1936, was 20 feet]

a. Silt, clayey, dark gray, thin bedded $(1939) \ldots \ldots \ldots \ldots \ldots \ldots$

b. Sand, medium-grained, well bedded; local coarser lenses of

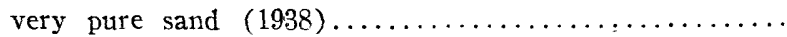

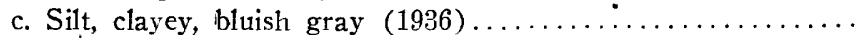

d. Sand, silty, light gray $(1936) \ldots \ldots \ldots \ldots \ldots \ldots \ldots \ldots \ldots \ldots \ldots$

e. Soily material, homogeneous; grades downward into mottled brown to gray sandy silt; extends to base of cut.........

Approximate

Inches

\section{Station MH 17}

[N. bank of brook, 30 feet W. of Hwy. 13 bridge; 1.1 miles N. of Hadley. Approximate distance below flood peak. March 1936, was 23 feet]

$a^{\prime}$. Silt, clayey, bluish gray, mottled with irregular brown patches; faintly sandy toward base $(1938) \ldots \ldots \ldots \ldots \ldots 2 \frac{1 / 2-5}{1}$ 
TABLE 23.-Sections showing recent flood deposits in relation to underlying deposits of unknown or doubtful origin-Continued

$\mathrm{b}^{\prime}$. Sand, fine, buff; local lenses of finely bedded silty sand at

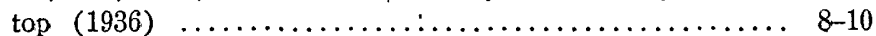

$c^{\prime}$. Soily material, dark, homogeneous; large roots; vegetation zone at top; extends to bottom of hole............. 7 .

Station MT 10

[Bank of Russellville Brook; 0.2 mile NNW. of Russellville. Approximate distance below Hood peak, March 1936, was 15 feet]

Inches.

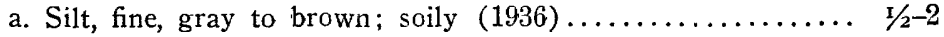

b. Silt, sandy, bluish gray, structureless; extends to bottom of hole

\section{Station MT 11}

[Bank of Dug Brook at W. end of Plumtree Road. Approximate distance below flood peak, March 1936, was 13 feet]

a. Silt, sandy, light gray, with bands of silt, fine, dark (1938).:

Inches

b. Sand, medium-grained, gray, faintly cross-laminated (1938)

c. Silt, sandy, dark gray, soil zone at top $(1936) \ldots \ldots \ldots \ldots$.

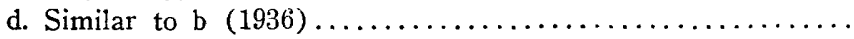

e. Silt, sandy, dark and soily; very rich in root material (pre1936)

f. Silt, sandy, gray; grades downward into sand; extend's to bottom of hole

lated with the flood of November 1927. It probably represents a compact soil formed from earlier flood deposits. Soily, homogeneous silt (station MTom I,g), which underlies flood deposits of pre-I936 age near the top of the high river bank 0.2 mile southeast of the Holyoke City Home is doubtless a somewhat disturbed meadow-surface deposit. Its faint, regular bedding suggests that it is a relatively recent flood sediment, rather than a member of the upper flood-plain sequence of the meadow in which it occurs.

A sample from station $\mathrm{MH} 2$ was collected from a low, swampy scour depression on the river edge of the flood plain 0.3 mile south of Hockanum. Its very fine texture $(4$, pl. $27, C)$, homogeneity, and topographic position support the view that it is a deposit laid down in very quiet, ponded waters, perhaps during the period $193^{6}-38$. It may be older, although much of the scour depression in which it occurs is said to have been cut in March 1936 . What is probably a typical representative of the upper flood-plain sequence in flood plain IV was found at a point near the Boston and Maine Railroad embankment 0.7 mile west of Hadley. This material (sample from station $\mathrm{MH} 4 \mathrm{c}$ ) is overlain by recent flood deposits and underlain by homogeneous, fine, tan silt. Nothing in its structure suggests that it is a more recent flood deposit, and its texture (b, pl. 27,C) is similar to that of materials in the loessial sequence. (See pl. 27,A.) 
Samples from station MH I3g, from a point near the mouth of the Fort River; $\mathrm{MH}$ 16,e, from an analogous point on Stony Brook; $\mathrm{MH}$ I7, $\mathrm{c}^{\prime}$, from a small ravine north of Hadley; and MT i I,e from the bank of Dug Brook r.5 miles north of Russellville, appear to be from somewhat disturbed deposits of flood-plain origin. Their textures are typical of flood deposits, except for the relative poorness of sorting characteristic of disturbed and reworked materials. The material at locality $\mathrm{MH}_{13}$, $\mathrm{g}$ is probably a part of the Fort River flood plain; the others are probably of Connecticut River derivation. Sample MT ıo, collected from Rusisellville Brook (Mount Toby quadrangle), is from a bed of structureless sandy silt covered by a thin veneer of 1936 flood deposits near the outer margin of the inundated area. It may be a local deposit of the brook itself, or an earlier, disturbed flood-plain deposit of the Connecticut. The latter is suggested by its texture, which is much like that of other floodplain materials, but its position in the field is more like that of a brook sediment.

Several deposits of unknown or doubtful origin were sampled at points above the level reached by the flood waters in March 1936; their mechanical analyses are plotted on plates $26, W$ and $27, C$. SN $2, b$ was taken from a very thinly laminated, compact silty sand bed on a high, narrow meadow surface on the southwest side of the Connecticut I.5 miles upstream from the Holyoke dam. Its field relations suggest that it is a local pond deposit in a shallow depression between the railroad embankment and the high bluff. This depression, according to reports, is partly flooded after every heavy raian. Samples from station $\mathrm{MH}$ 3,a-c were collected at Hockanum, and appear to represent soily materials derived from old flood-plain sediments at the outer margin of a river terrace. $\mathrm{MH}$ 3, a is a dark, rich soil, $\mathrm{MH}$ 3, b is an underlying transitional material, which

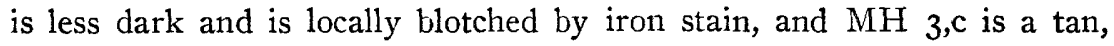
fine, structureless silt. Their common derivation is reflected in the correspondence of their textural analyses.

Two samples were collected f 1 om the low, grassy flat beside Bachelor Brook at the bridge of State Highway 63. (See Mount Holyoke quadrangle.) Here 4 inches of white sand $(9, \mathrm{pl}, 27, C)$ overlies a thick, bluishgray silt, which conţains blotches of finer, more strongly bluish material. (See 10, pl. 27,C.) A zone containing small fragments of old brick occurs 6 inches below the top of the bluish-gray silt. Both sediments appear to have been deposited by floodwaters of Bachelor Brook, and the upper bed may be of 1936 or 1938 age, possibly both. Neither bed persists for a great distance away from the stream. On the banks of Hart Brook 0.2 mile from its point of entry into Old Mill Pond (Mount Holyoke quadrangle) a dark, rich sandy soil overlies lenses of stream-laid sand. The analysis of this sandy soil (II, pl. 27,C and g, pl. 26,W) shows it to be moderately sorted and fairly coarse. It may represent $d$ 
flood-plain deposit of Hart Brook, possibly mixed with loessial material from nearby Connecticut River meadow areas.

The deposits discussed in the foregoing paragraphs are the only ones observed whose origins could not be determined in the field with reasonable assurance. All sediments obtained from levels above those reached by the 1936 floodwaters are explainable as materials of other than fairly recent Connecticut River flood origin. The absence of any recognizable modern flood deposits at these higher levels does not constitute absolute proof that such areas were never visited by modern floods. 'In his discussion of similar features in the Ohio Valley, Mansfield ${ }^{96}$ states :

On flat ground the growth of vegetation, the action of frost, erosion by wind and rain, to say nothing of cultivation or other activities of man, may be expected to blur or even obliterate all traces of an earlier record. On valley sides, slumping and stream erosion may be added to the list of agencies unfavorable to the preservation of such evidence. Even the rising stage of the flood $* * *$ might scour away traces of deposits left by earlier floods in such positions.

So far as the Connecticut Valley is concerned, the last sentence of this statement applies only to those areas near but within the margin of the area inundated in 1936; the other statements, however, apply equally well to extramarginal areas. In spite of the chances for rapid obliteration of an earlier record, it is impressive that no deposits ascribable to a modern flood were observed in many exposures and test holes above the reach of the 1936 flood.

\section{RELATION OF THIS STUDY TO THE STUDY OF EARLIER FLOOD DEPOSITS}

In general, the occurrences of floods of extraordinary magnitude in the Massachusetts portion of the Connecticut Valley may be said to bring back temporarily conditions of sedimentation that normally existed there hundreds or even thousands of years ago. During the great flood of March 1936, for example, the low terrace received much the same type of sediment that is deposited on the high flood plain by ordinarily great floods, and the high flood plain in many places received the type deposited ordinarily on the low flood plain. These generalities should be viewed with reservation, however, because discharges sufficiently great to create crest heights equal to those of the two recent floods also cause many abnormalities in. the types and positions of debris transported and deposited. Although the low terrace was inundated in March 1936 to approximately the same depth as the low flood plain is during ordinary spring high-water stages, the deposits laid down on the two areas are neither texturally alike nor of comparable thickness.

Coarse sand beds within sections of otherwise fine flood-plain materials record the transporting power of great floods. Such floods are thought

Mansfield, G. R., op. cit., p. 715, 1938. 
to be responsible for the presence of beds of sand I to 3 inches thick that were observed at several places in the lower part of the upper floodplain sequence of terrace and high flood plain sections. The I936 sand bed of the low-terrace section appears to be unique in that it lies in the upper part of the upper flood-plain sequence.

The mechanical analyses of recent flood and older flood-plain sediments demonstrate that they are textural counterparts in some places; but distinctly different in others. It is to be expected that the usual relatively fine-grained flood-plain sediments would be laid down during, high water and to a certain extent during rising and falling corditions of the great floods, and that coarser materials would be deposited during higher stages. This appears to be true of the sediments examined. The sediments of recent extraordinary floods therefore furnish a clue for the interpretation of somewhat similar conditions in older river-deposit sequences, or even in certain consolidated sediments. The study of such materials, however, should be undertaken only after the pertinent physiographic history of the specific river or region is thoroughly understood.

\section{MAJOR:FLOOD PERIODICITY}

\section{THE PROBLEM}

Determination of the frequency and magnitude of great floods has an important bearing on the design of dams, spillways, bridges, and similar works, and is a problem that has engaged the attention of engineers for many years. In problems of this sort, the magnitude of floods that are equalled or exceeded, on the average, once in Io years is termed a Io-year flood, and similar derivations are used for the terms 25-year, I00-year, and I,000-year floods. Structures affected by river discharges are commonly designed to withstand the effects of so-called Ioo-year floods, but because of the short period of available records, there may be considerable uncertainty as to the reliability of the determination of a flood of such periodicity.

For a direct comparison of great floods over a long period of time, it is necessary to employ their recorded crest heights, because it is only recently that discharge records have been kept or calculated for most rivers. Even though the gage heights may be accurately referred to sea level, they do not necessarily constitute a true comparison of the discharges. Man-made encroachments in the channel raise flood stages along the river for appreciable distances upstream, and artificially or naturally introduced detritus tends to raise the bottoms of aggrading streams and thus raise flood crests. This effect has been very pronounced in the Sacramento Valley, Calif., where long-time records indicate several feet of channel-bottom rise during the past century.

Along the Connecticut River a far more important factor, on a broader 
scale, has been its response to lowering of base level during postPleistocene time. It has lowered its bottom about 80 feet in the Montague Meadows and about 50 feet elsewhere since the draining of the late glacial Connecticut Valley lake. If the length of Recent time be taken as 10,000 to 25,000 years, the discussion here of so-called $1,000-$ year floods or the comparison of any floods over a very long period of time on the basis of their crest heights as referred to points along the valley is seen to be an entirely useless and misleading procedure. In view of the Recent history of the Connecticut Valley, therefore, it is not a question of a rise of river to heights greater than those of the March 1936 flood, but rather one of the length of the period prior to 1936 since the last flood of equal or greater height, as referred to points along the course of the river.

\section{HISTORIC RECORDS}

According to the most complete available records of Connecticut River flood stages, ${ }^{97}$ the flood of 1936 was the greatest ever noted at Hartford, Conn., and at Holyoke and Springfield, Mass. The earliest record relates to the flood of March 1639, and thus a 300-year period of more or less complete data for crests of great floods is available. Those flood crests that reached heights of more than 22 feet on the Hartford gage are indicated on plate 29 .

The continuous record of floods, too short, however, for such determination within close limits of confidence, indicates that the flood of November 1927 approximated a 25-year flood, so far as the lower reaches of the Connecticut River are concerned; nevertheless, it was actually exceeded in height but once by an earlier recorded flood. On the other hand, those of 1936 and 1938 are so much higher that they must be classed as extraordinary. It is possible that earlier floods of nearly as great magnitude may have escaped inclusion in the records. Such omissions seem rather unlikely, however, in view of the abundance of published data on early flood heights in the Connecticut Courant (now Hartford Courant) and many other newspapers and journals, to say nothing of private letters and other papers that have been made available to compilers of data of great floods. ${ }^{98}$

\section{PROBABILITY STUDIES}

The probability theory as applied to flood studies has been used much during the past 25 years. There is little doubt that the laws of probability can be employed to great advantage in the determination of the magnitude of the so-called 25-year flood, and in rare instances for a rough estimate of the magnitude of the Ioo-year flood, on a given river, pro-

\footnotetext{
rr Kinnison, H. B., Conover, L. F., and Bigwood, B. L., Stages and flood discharges of the Connecticut River at Hartford, Conn.: U. S. Geol. Survey Water-Supply Paper 836-A, pp. 16-18, 1938.

${ }^{88}$ Idem, pp. 2-4, 1938.
} 
vided that reliable records are available for long periods. The extrapolation of such basic data to reach numerical values for probable I,oooyear flood heights, however, appears to be a very risky procedure, and recently has drawn protests from many sources. Furthermore, extraordinary floods that have occurred along many rivers since such estimates were made have demonstrated their manifest inaccuracy.

It would seem that the "thousand-year flood" is largely a catch phrase, as pointed out by Merriam, ${ }^{69}$ and has little or no real significance. This is certainly true along the downward-cutting Connecticut River, where great floods of equal discharges spaced at I,000-year intervals would almost-surely reach entirely different heights, as referred to points along the valley and thus affect the various flood-plain and terrace levels in entirely different ways. Further, disagreement seems to exist between different individuals as to the methods of applying probability laws. According to Jarvis," "the flood which one man expects one year in 500 will be considered by another using the same data as likely to occur one year in $57 . "$

As Creager ${ }^{2}$ has pointed out, the recorded flood peaks on various rivers continue to rise as new data are added to the records each year. In this way, the basic data themselves are unsatisfactory for the calculation of great floods. The situation is summarized by the statement: ${ }^{3}$

* * * it has been proved by advanced studies and a greater accumulation of data, that the probability method is entirely inadequate

Thus floods have occurred on rivers which, based upon probability studies of prior records of considerable length, would have a frequency, not of the usually adopted 1,000 or 10,000 years, but of once in millions or even billions of years.

This may well apply to the great flood of 1936 in the Connecticut Valley, so far as its position with respect to reference points in the valley is.concerned. Furthermore, the occurrence of the almost equally great hurricane flood only 2 years later indicates that for a reasonable basis of extraordinary flood frequency determination, periods of tens of thousands of years must be used. These would carry far back into the glacial epoch.

\section{EVIDENCE OF MODERN-FLOOD DEPOSITS BENEATH THE FLOOD DEPOSITS OF 1936}

So far as observations could be carried, the flood deposits of 1927 or earlier age are confined to areas that lie at appreciable distances beneath the level reached by the flood waters in March 1936. Wherever they occur, they are thinner than the overlying 1936. and 1938 deposits, but in many places it has been impossible to determine whether this was due .primarily to differences in flood-crest heights or in durations of the floods.

\footnotetext{
90 Merriam, Thaddeus, letter to editor, Civil Eng., vol, 9, 1939.

1 Jarvis, C. S., Discussion in Am. Soc. Civil Eng. Proc., Papers and Discussions, p. 2028, 1927.

'Creager, W. P., Possible and probable future floods: Civil Eng., vol. 9, pp. 668-670, 1939

s Creager, W. P., idem, p. $668,1939$.
} 
As discussed in a previous connection, the absence of earlier modernflood deposits beneath those of recent floods at any given point does not constitute compelling evidence of a corresponding absence of earlier modern floods there; it is certain, however, that the consistent absence of such deposits near the margins of areas flooded in 1936 is suggestive.

\section{EVIDENCE OF DEPOSITS AT LEVELS HIGHER THAN THE FLOOD CREST OF 1936}

All examined deposits from points higher than the flood crest of 1936 were attributable to origins other than earlier recent floods. Most of them are much older, and have been derived from the underlying floodplain deposits. Others were laid down by local brooks. It is true that in many places evidences of earlier recent deposits may well have been removed by erosion or incorporated completely into underlying materials, but their consistent absence in recognizable form is noteworthy, especially as it is entirely compatible with other, more reliable evidence bearing on the question.

\section{EVIDENCE FROM LOW RIVER-TERRACE SECTIONS}

The most compelling evidence bearing on the periodicity of extraordinary floods is that furnished by sections of the low terrace (III) which were thinly inundated in 1936 . The relatively coarse deposits of this flood are texturally unique in the upper flood-plain sequences of such terraces and are considered by the writer to suggest strongly that the terrace surfaces were flooded in 1936 for the first time since they ceased their functions as active flood-plain surfaces. The discussion bearing on this conclusion appears on pages II 7 -I 20 .

Estimation of the length of time since the low terrace was an active flood plain involves evaluation of the rate of base level lowering, and hence crustal tilt and climatic variations, in the valley throughout postPleistocene time. Such evaluation is, of course, impossible. As the low terrace (pl. 8, III) is but the third of a series of five general levels developed as successive flood plains by the Recent Connecticut River, however, it must have been abandoned as a regularly active flood-plain many hundreds, perhaps even a few thousands of years ago. The present high flood-plain (pl. 8, IV) itself now appears to be in the process of abandonment by the river, so that the low terrace was probably active at least one flood-plain cycle ago. The period of time occupied in the completion of a single flood-plain cycle would be about one-fourth that of Recent time if the base-level lowering were of constant rate or if its pulses were evenly spaced in occurrence. This would assign a value of 2,500 to 6,000 years to the period prior to 1936 since the occurrence of an equal or greater flood, judged by present standards of crest-height measurement. The assumptions upon which this estimate is based may

$689520-47-10$ 
be open to serious question, however, so that a much lower figure may well be more reliable.

\section{METEOROLOGIC FACTORS}

The probability method has been applied to rainfall data in efforts to determine flood periodicity, with a certain amount of success for relatively small floods. The method has commonly broken down for extraordinary floods, however, because so many additional factors are involved. According to Creager, ${ }^{4}$

Data on floods of many years ago and gagings of more recent floods have shown conclusively that there must be a combination of meteorological conditions which give rise to storms of a special class, which occur so infrequently that their resulting floods seldom appear on the published records of a given river. These storms and their resulting floods seem to be in a different class from ordinary ones and to follow some law of their own.

The truth of this statement was emphasized in New England by the several meteorologic conditions which united to produce record-breaking runoff in March 1936. In a general discussion of flood-producing factors in the northeastern United States, Hoyt and Langbein ${ }^{5}$ make the following statement:

Analyses of major floods of record in this area indicate that almost invariably these outstanding floods have been associated with melting snow and that the limiting flood-runoff range for single flood events is generally between 10 and 15 inches. The snow, though shallow, possesses a high water-density generally 20 to 30 per cent which constitutes at all times a potential source of flood-runoff predictable as to time and magnitudue only by constant observation. *** Ice break-up is a factor that aggravates flood-conditions during winter and spring freshets. Nonwinter floods in this region occur only as the result of intensive storm-rainfall that follows a period of more than normal rains which serve to prime the ground. Direct runoff associated with these storms seldom exceeds 8 to 10 inches. Nonwinter floods generally attain lower stages and are less prolonged than winter or spring floods. The more sharply concentrated runoff associated with the "cold front storms" of the summer and fall seasons is largely due to the intensive nature of these storms and to soil-conditions which only permit active runoff during the most intensive parts of the storm. The "cold front storms" also embrace smaller areas and the resultant floods are usually severe in local areas, particularly in the smaller streams situated in the eye of the rain-storms.

Available records indicate that 62 percent of all damaging floods in the lower reaches of the Connecticut River occur during the months of March, April, and May, and that only 7 percent occur during the 4-month period June to September. Plate 28 shows the relative frequency of occurrence of damaging floods along the lower Connecticut for 2-day periods throughout the year, as well as similar data for more severe floods. The number of floods during each period is indicated by the

- Creager, W. P., op. cit., p. 668, 1939.

S Hoyt, W. G., and Langbein, W. B., Some general observations of physiographic and climatic influences on floods: Am. Geophys. Union Trans., 20th Ann. Meeting, 1939, pt. 2, p. 170, Nat. Research Council, 1939. 
relative lengths of the vertical lines. Concentration of floods, especially of severe ones, in the spring of the year is very marked.

As shown on plate 29, the floods that occur as the result of heavy storm precipitation in the fall months are not common, but may be very severe. Those of November 1927 and September 1938 were of this type. On the other hand, the greatest recorded flood, that of March 1936, was an ordinary phenomenon of spring, so far as the identity of factors contributing to its genesis is concerned. The unusual magnitudes and coincidence of these factors were responsible for its tremendous discharges.

Plate 30 contains a general summary of certain significant meteorologic conditions over the northern and central parts of the Connecticut River drainage basin for the period 1888-1939, and was constructed from information published by the United States Weather Bureau. At the base are the precipitation data, the ruled areas representing mean precipitation for December, January, and February and the solid lines that for March. Above these are the mean temperature values for January, February, and March, represented by vertical lines of varying length extending above or below the mean values for the period I888-I939. Correlated with the meteorologic data are the flood-crest values referred to the Hartford, Conn., gage. It is evident that for a maximum of spring runoff, the precipitation values should be high, the January February temperatures low, and the March temperature high. How well these conditions were fulfilled during the period December to March I935-36 is evident from the figure.

It is true that the data are considerably generalized by such a monthly presentation, and therefore that conclusions drawn from them should be viewed with caution; nevertheless, they demonstrate very clearly the broad trends involved in the origin of severe spring floods. Data for the month of April are not included because floods during that month are less affected by melting of large quantities of snow, and therefore are more directly the results of precipitation alone. Of all factors involved in the production of March floods, March precipitation appears to be most critical, although severe floods occurred without such great precipitation during several years and severe floods did not occur in spite of great March precipitation during several other years, notably I899, I890, and 1930. These exceptional cases are clearly the result of lack of coordinaton with winter precipitation, winter temperature, or March temperature, or combinations of these factors. Further examination of the meteorologic conditions in $1935-36$ discloses that in spite of their excellent timing, several could have been of greater magnitude and effect. Had the winter temperatures been as low as those of certain earlier years, had the March temperature been as high as it was in 1903, and had the winter precipitation been as high as that of 1900, the discharge during 
the great flood of 1936 could conceivably have been far greater than it was.

Although a great many serious floods occur in April, the chances for their approaching the magnitude of the 1936 flood do not appear to be so great. Even during very cold winter and early spring seasons, much of the snow cover melts from the drainage basin before April and thus lessens the effect of a very important source of rapid runoff. In the same way floods during fall and summer are almost solely the result of unusual storm precipitation, and as such rarely could approach the magnitude of the great flood.

\section{SUMMARY AND CONCLUSIONS}

Because the Connecticut River has been engaged in lowering its bottom since the draining of the late glacial valley lake, discussion of so-called I,000-year floods on the basis of their crest heights as referred to points along the valley is of no value. The more significant question of the period of time prior to 1936 since the last flood of equal or greater height can be answered only approximately,

The period over which actual flood records are available is only 300 years, hence probability -studies, as applied to the occurrence of extraordinary floods, must be cast aside for lack of sufficient basic data. The same conditions apply to probability studies of the meteorologic factors that cause such floods. Studies of flood sediments, however, give more satisfactory and tangible results. The evidence of these deposits in low river-terrace sections, in positions beneath the 1936 flood deposits, and at levels higher than the 1936 flood crest, though not conclusive, is at least impressive in its directness and uniform in its implication.

From a combination of historic records of meterologic and hydrologic conditions in the Connecticut River drainage basin, together with evidence furnished by the great flood deposits and materials associated with them, the conclusion seems valid that no flood as great as or greater than that of March 1936 has visited the lower reaches of the Connecticut since civilization began in the valley, and probably not for an additional period of several hundreds of years prior to that time. This in no way suggests that a repetition of the great flood will not occur for many years to come because there is little reason to doubt that a flood of equal or even sensibly greater magnitude could occur at any time. From a study of the meteorologic factors that cause these periods of extraordinary runoff, however, the chances for such a repetition in the near future or in any relatively short period appear very small. 


\section{ENGINEERING APPLICATIONS}

From the data referring to extraordinary-flood periodicity in the Connecticut Valley it appears that most of the structures built along or across the river should be safe from the effects of future floods if designed to withstand those of the great flood of 1936 with a comfortable margin of safety. In some instances, the cost of construction according to such design might be greater than could be justified by the value of the structure itself, in which case they could be built to less rigid specifications and with expectation of severe damage or even destruction by another extraordinary flood. Such decisions are for engineers to make, although where human life is involved, it becomes difficult to compromise. The following pages contain a brief series of recommendations concerning future protection against flood damage.

\section{POSSIBLE CUT-OFFS}

A cut-off by the Connecticut River of its single remaining meander in Massachusetts, the great loop at Hadley, is to be expected under normal conditions. That this cut-off has not occurred in the past has been due to the incision of the river into its high flood plain ( $\mathrm{pl} .8, \mathrm{IV}$ ) and low terrace (p1. 8, III). The outer bank at the first bend north of Hadley has thus become very high, the processes of lateral cutting have been slowed to a minimum, and the bend has been essentially stable for decades. The heavy tree cover on the outer bank also has been effective in keeping erosion within very low limits. A very grave danger of cutoff exists nevertheless, not by lateral bank cutting, but by overflowing the high flood plain near the north end of Hadley Street and establishing a new channel through a coalescing series of swirl pits. The behavior of the 1936 flood gave clear warning of the possible future occurrence of just such a cut-off in a manner complete enough for permanent elimination of the present swing of the river toward Northampton.

In addition to the loss of valuable, highly developed property in Hadley, a cut-off would seriously accelerate erosion on bends farther upstream in response to a temporary steepening of the river profile, precisely as the Mount Tom cut-off did in I840. Construction of a dike, larger than the present one, might be considered along the south and east banks of the river north of Hadley. It should be built to a height several feet above that of the low terrace level, or to I35-I 50 feet above sea level. The slight raising of great flood crests occasioned by this confinement of flow probably would necessitate construction of a similar, lower dike north and east of Northampton, in order to save that city from serious inundation. The careful coordination of such channelconfining structures is a matter of the greatest importance.

The swirl-pit area north of Hatfield is another, though not so important danger point. The present road fill across the channel that the 
river waters made when they broke from the old oxbow area in 1936 seems inadequate to prevent a repetition of this occurrence and further damage to fertile meadowlands. If this barrier were strengthened, there would be danger that future great-flood waters might seek an outlet through a long-abandoned channel to the east and thus flow in a concentrated, devastating rush through the town of Hatfield. This occurred in 1936 , but was not serious because some of the waters escaped through the swirl-pit area. It is suggested, therefore, that a relatively high-level relief channel be constructed across this swirl-pit area, which is now useless land. Such a bypass would return to the normal channel much of the water that accumulates in great quantities in the old oxbow area during extraordinary floods, and would involve no danger of establishing a new river course, because the old oxbow bottom is several feet above present mean river level. In addition, a short east-west dike might well be constructed north of Hatfield at a point about 0.7 mile west-southwest of the swirl-pit area; this would protect the town from recurrence of inundation by rapidly moving floodwaters.

\section{DAMS}

The dam of the Turners Falls Power and Electric Co., at Turners Falls, Mass., appears to be capable of handling discharges as great as those of March 1936 with little danger of flow over the abutments. Flow over the abutments at the Holyoke Dam, on the other hand, was seriously threatened during the great flood and was averted only through the heroic efforts of many men who placed thousands of sand bags at the danger points. Besides powerhouse damage, such a flood flow over the west abutment of the dam could enter the Holyoke canal system and cause great damage to some of the highly developed areas in the city. Provision should be made for entirely adequate and permanent protection against an occurrence of this nature.

The bypassing of damsi to form new channels is an especially grave danger on tributary streams, as shown by the action of the hurricane flood waters at Bircham Bend on the Chicopee River and at Woronoco on the Westfield. A new dam, which was constructed over the bypass channel at the Woronoco locality, is itself poorly protected on one end by a low, entirely inadequate gravel dike. Failure of this dike during a future flood would cause a repetition of bypassing and sudden release of tremendous volumes of water to the already swollen river.

The effects of failures of smaller dams, many of which were built without sufficient consideration of great flood discharges, have been previously summarized ${ }^{6}$ in the following statement of flood damage in 1927 :

In several places the release of a small millpond proved to be of tremendous

- Clark, G. G., McNary, J. V., and Jarvis, C. S., New England floods and highways, in Kinnison, H. B., The New England flood of November 1927: U. S. Geol. Survey WaterSupply Paper 636, p. 100, 1930. 
effect, for it produced an additional wave just sufficient to remove large stocks of lumber, houses, barns, and bridges which otherwise would have remained in place. Armed with such wreckage and battering rams, the stream swept all before it, occasionally halting at some obstruction long enough to inundate sections of the valley to depths never before known, drowning livestock herds that were supposedly safely housed, and then resuming progress beyond the shattered barrier with redoubled fury. Thus the maximum damage due to both inundation and torrential velocity was sustained where a relatively small storage dam of reliable construction would have'kept the stream within prescribed bounds.

These events are typical of those in the Massachusetts part of the Connecticut River drainage basin, especially along the tributary rivers, during September 1938. It is suggested that all dams along such rivers be subject to rigid regulations of location and design, these regulations to be determined from studies of all the meteorologic, hydrologic, geologic, and engineering factors involved in each place. They should apply to both new and preexisting structures.

\section{BRIDGES}

In general, failure of bridges during the two recent floods was due to the pressure of water supplemented by the heavy battering of ice, trees, wreckage, and other floating debris. Undermining of abutments and settling or removal of piers were common on the higher-gradient tributary rivers, but of little consequence along the Connecticut. Most of the damage and destruction was directly traceable to the increased current velocities and debris concentration created by the channel constrictions at the bridges. Such constrictions are caused by encroachment of bridge approaches and by inadequacy of openings beneath bridges for passing extraordinary flood-waters satisfactorily.

The Davitt Memorial Bridge in Chicopee (see pl. $3 \mathrm{I}$ ), a reinforced concrete arch structure, proved inadequate to accommodate the discharge of the Chicopee River in September I938. It is said that the difference in water level on the upstream and downstream sides of the bridge amounted to several feet. That the bridge remained intact under such conditions, despite its design, is a tribute to its construction. The immense volumes. of water and debris that pass through such constricted openings during great floods must produce an immense upward component of force. There can be little doubt of the effectiveness of such a vertically applied force on a typical bridge. Several witnesses, for example, reported that a small but well-constructed bridge over Mill Brook in Charlemont literally exploded when the pressure of water and debris under it became too great during the flood of September I938.

Many structures along the Connecticut were severely battered or carried away entirely by the pressure and impact of water and floating debris when an added few feet of clearance would have preserved them nearly intact. At some places the roadway itself was at too low a level; at 
others the roadway was high enough, but valuable clearance was lost through use of deck trusses and deck-plate girders. For example, if the Central Vermont Railway bridge near Northfield had been of an overhead truss type on the same grade, it doubtless would have passed the 1936 flood waters with little or no damage.

Further relief from floodwaters at railway structures could be accomplished through the use of more spans and less approach fill. The additional initial cost of such spans must be justified, however, by the expected savings in repair costs and the lessening of downstream damage as a result of subsequent floods. Highway bridges should be considerably higher than their approach fills wherever possible, so that relief from floodwater is ultimately accomplished at the expense of fill material rather than at the expense of the structures themselves. If the approaches are sufficiently low, they soon cease to act as channel restrictions, as they are overtopped rather quietly without the formation of damaging flood waves. If the approaches to many wood structures had been lower, the structures themselves would not have been detached and floated downstream to batter other bridges during the recent floods.

A serious effect of many inadequate culverts and small bridges is the bypassing of floodwaters and debris through adjacent nonchannel areas. For example, a low, small highway bridge over Avery Brook west of East Charlemont (see pl. 32 and Hawley quadrangle) was choked with debris during both recent floods, and both times it caused by-passing of most of the flow through an adjacent auto court. Many of the buildings were severely damaged or destroyed, and a blanket of sand several feet in thickness was deposited over the entire area. Similar inadequate culverts under the Boston and Maine Railroad along the Deerfield River (pl. $33, A$ ) caused overtopping and partial destruction of the right-of-way embankment in more than I 5 places between Shelburne Falls and Charlemont. Certain types of bridge structures should be entirely avoijded, so far as flood effects are concerned. Small, multiple-arch bridges, pile trestles, and trusses and girders reinforced by piling (pl. $33, B$ ) are effective traps for debris. As such they cause a serious damming of floodwaters, and if destroyed they release very damaging flood waves. 


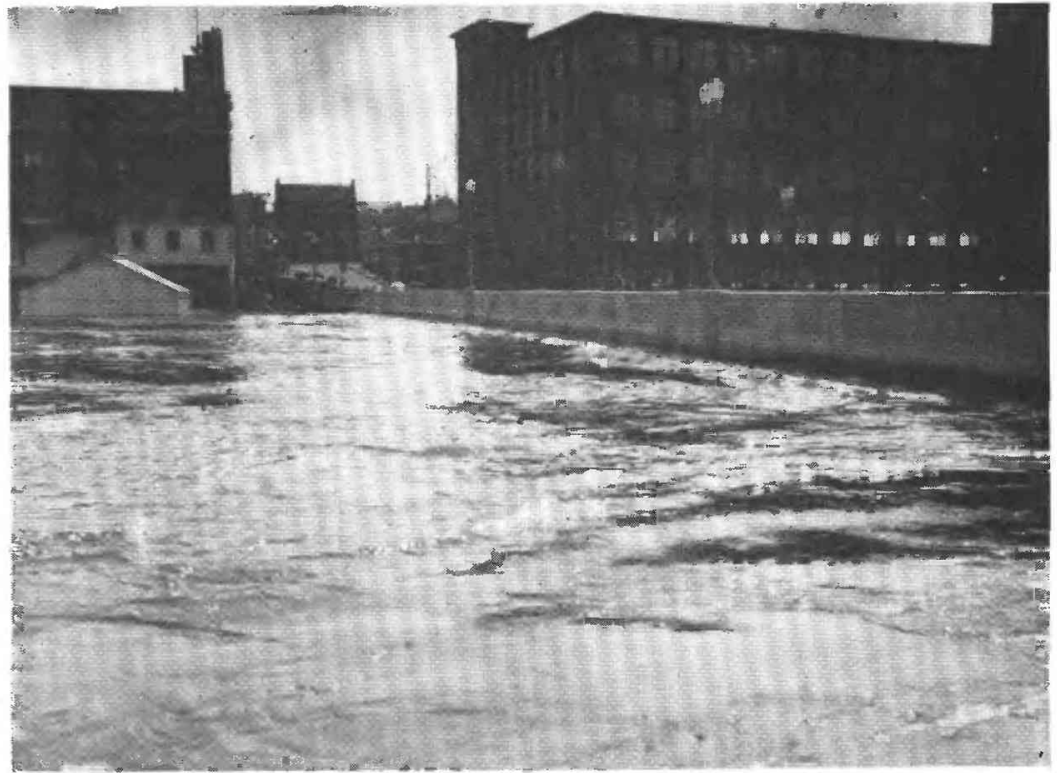

A. CHICOPEE RIVER IN FLOOD, SEPTEMBER 1938.

Courtesy of Holyoke Daily Transcript-Telegram.

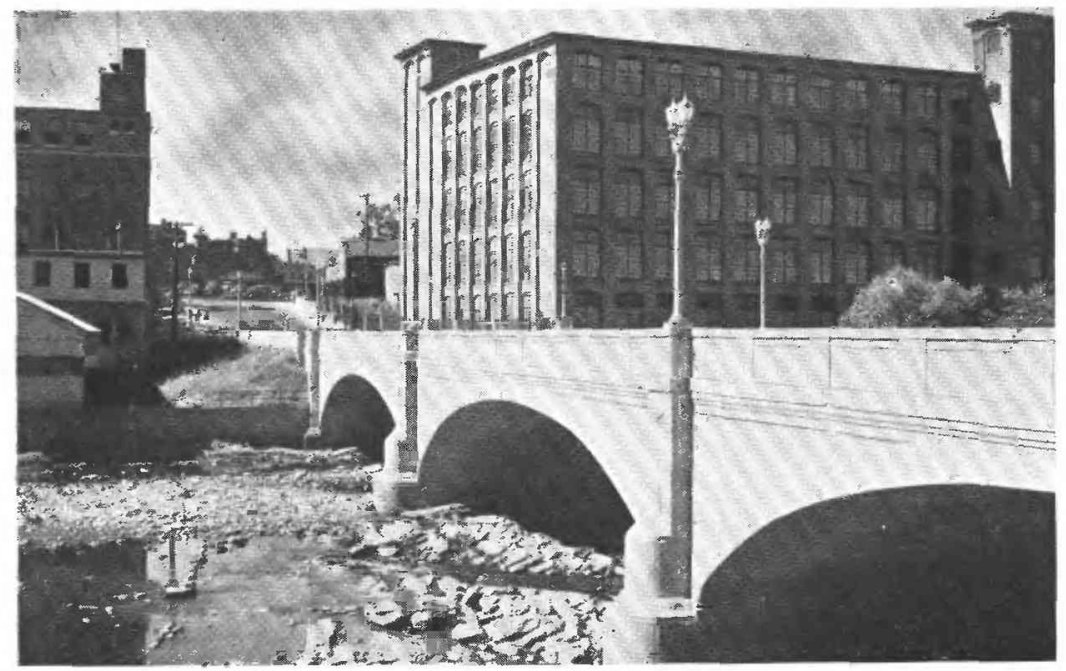

B. CHICOPEE RIVER AT LOW-WATER STAGE, JULY 1939.

DAVITT MEMORIAL BRIDGE IN CHICOPEE. 

MECHANICAL ANALYSES OF FLOOD SEDIMENTS AND ASSOCIATED MATERIALS, CONNECTICUT RIVER DRAINAGE BASIN, MASSACHUSETTS

The following tables contain mechanical analyses by M. D. Reeves and J. D. Hem of flood sediments and associated materials from the Connecticut River Basin. The analyses are arranged as percentages according to the size of the individual particles in each sample.

In the first column of the tables a capital letter used with the sample number refers to the quadrangle from which the sample was taken. A small letter refers to the relative vertical position of the sample in the test pit, except in the tables dealing with fan and river-bar samples, where the small letters refer to different samples at the same general locality :
E. Easthampton
N. Northfield
G. $7 \frac{1}{2}{ }^{\prime}$ Greenfield
SF. Shelburne Falls
H. Hawley
MF. Millers Falls
MH. Mount Holyoke
SN. Springfield North
MT. Mount Toby
SS. Springfield South
Wo. Woronoco
MTom. Mount Tom
WS. West Springfield

The second column gives the relative age and position of the sample, based on field interpretation:

36. Deposit of flood of March 1936.

38. Deposit of flood of September 1938.

39. Deposit of spring high water, 1939.

Pre-36. Deposit of flood of probable occurrence during 150-year period prior to 1936.

OF. Older flood-plain deposit.

$\mathrm{X}$. Deposit of unknown or doubtful origin. *

Top

Mid. Relative vertical position of sample within a flood sequence.

Bot.

In column three, in addition to the geographic location, a more definite location is given:

Bk. At or near river bank.

Trib. At bank of small tributary stream, but near river.

FP. On flood plain. 
CONNECTICUT RTVER

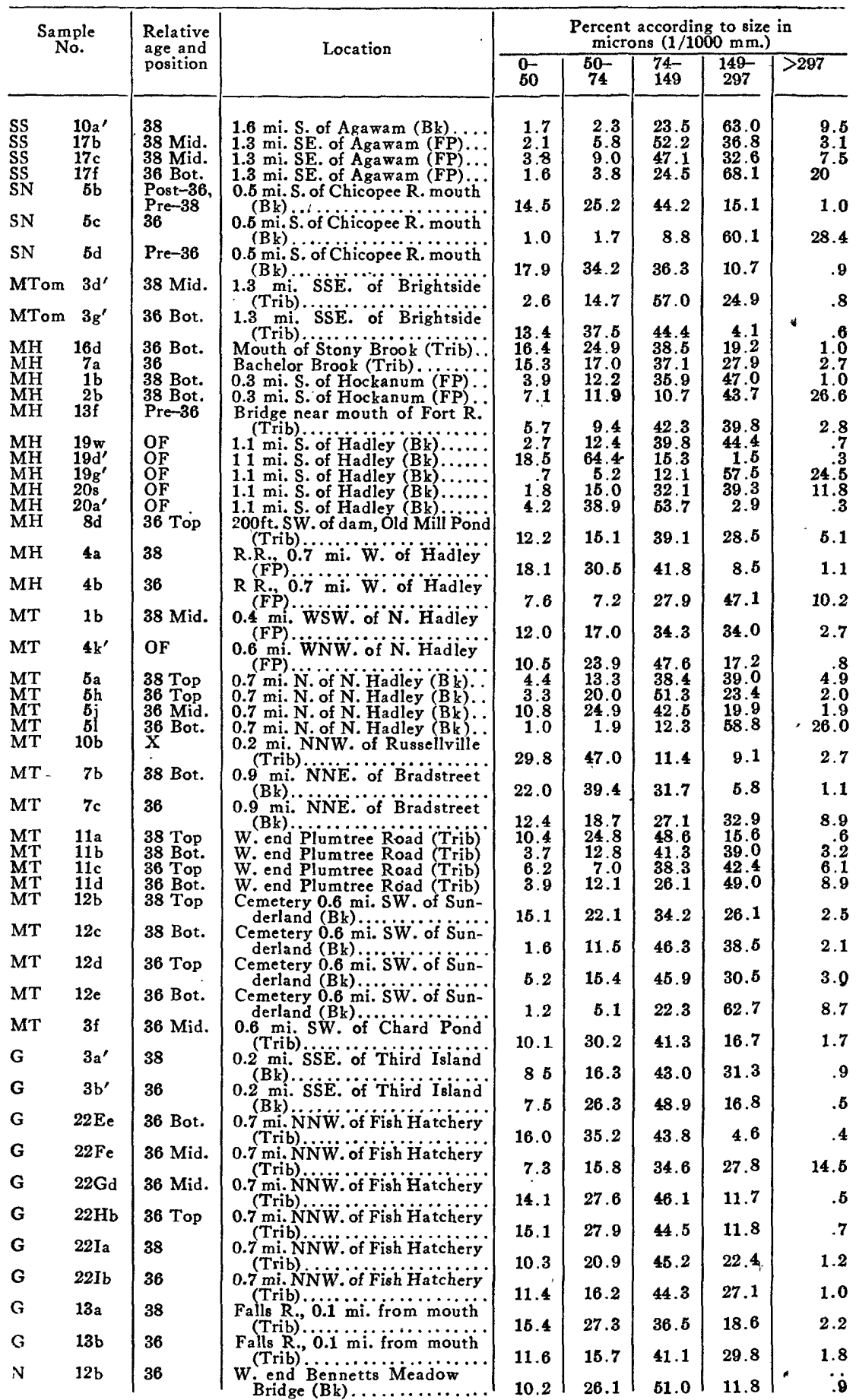


CONNECTICUT RIVER-Continued

\begin{tabular}{|c|c|c|c|c|c|c|c|c|c|}
\hline \multirow{2}{*}{\multicolumn{2}{|c|}{$\begin{array}{l}\text { Sample } \\
\text { No. }\end{array}$}} & \multirow{2}{*}{$\begin{array}{l}\text { Relative } \\
\text { age and } \\
\text { position }\end{array}$} & \multirow{2}{*}{ Location } & \multicolumn{6}{|c|}{$\begin{array}{l}\text { Percent according to size in } \\
\text { microns }(1 / 1000 \mathrm{~mm} .)\end{array}$} \\
\hline & & & & $\begin{array}{l}0- \\
50\end{array}$ & 74- & & & \begin{tabular}{l|l}
$9-$ \\
97
\end{tabular} & $>297$ \\
\hline \multirow{10}{*}{$\begin{array}{l}\mathrm{N} \\
\mathrm{N} \\
\mathrm{N} \\
\mathrm{N} \\
\mathrm{MF} \\
\mathrm{MF} \\
\mathrm{E} \\
\mathrm{E}\end{array}$} & \multirow{2}{*}{$\begin{array}{r}13 \mathrm{~d} \\
8 \mathrm{a}\end{array}$} & \multirow{2}{*}{$\begin{array}{l}3 \dot{6} \text { Bot. } \\
38 \text { Top }\end{array}$} & S. end of Bennetts Meadow & 11.3 & 30.6 & \multicolumn{2}{|c|}{52.3} & 5.5 & .3 \\
\hline & & & $\begin{array}{l}300 \mathrm{ft} \text {. N. of SE. end C.V.R.R. } \\
\text { bridge (Trib) }\end{array}$ & 10.8 & 26.7 & \multicolumn{2}{|c|}{52.0} & 10.0 & .5 \\
\hline & $8 d$ & 36 Mid. & $\begin{array}{l}300 \mathrm{ft} \text {. N. of SE. } \\
\text { bridge (Trib). }\end{array}$ & 9.9 & 23.9 & \multicolumn{2}{|c|}{45.6} & 18.3 & 2.3 \\
\hline & $10 a^{\prime}$ & & $300 \mathrm{ft}$.S. of NW.e & 14.9 & 26.9 & \multicolumn{2}{|c|}{40.3} & 17.2 & 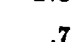 \\
\hline & $2 \mathrm{~b}$ & 38 Mid. & $0.4 \mathrm{mi}$ NE of French King & 13.0 & \multirow{2}{*}{30.0} & \multirow{2}{*}{\multicolumn{2}{|c|}{42.3}} & \multirow{2}{*}{13.3} & 14 \\
\hline & $3 c$ & 36 Top & Fourmile Brook, near mouth & 10.0 & & & & & 1.4 \\
\hline & & & $0.5 \mathrm{~m}$ & 5.6 & $\begin{array}{l}13.8 \\
17.7\end{array}$ & $\begin{array}{l}58.0 \\
45.4\end{array}$ & \multicolumn{2}{|c|}{$\begin{array}{l}21.5 \\
30.5\end{array}$} & $\begin{array}{r}1.0 \\
.8\end{array}$ \\
\hline & & & $\mathrm{Br}$ & 16.7 & 24.8 & 39 & \multicolumn{2}{|c|}{15.8} & 2.8 \\
\hline & & & & \multicolumn{6}{|c|}{$\begin{array}{l}\text { Percent according to size in } \\
\text { microns }(1 / 1000 \mathrm{~mm})\end{array}$} \\
\hline & & & & $\begin{array}{l}0- \\
20\end{array}$ & $\begin{array}{c}20- \\
50\end{array}$ & $\begin{array}{l}50- \\
74\end{array}$ & $\begin{array}{l}74- \\
149\end{array}$ & $\begin{array}{l}149- \\
297\end{array}$ & $\begin{array}{r}>297 \\
4\end{array}$ \\
\hline SN & $1 b$ & 3 Bot. & $\begin{array}{l}1.1 \mathrm{mi} . \mathrm{NW} \\
\text { a (FP). }\end{array}$ & 2.2 & 6.5 & 12.8 & 41.8 & 34.4 & 2.3 \\
\hline SS & $3 e$ & 27 & of $\mathrm{Big} \mathrm{Is}$ & 68 & 223 & 12.0 & 41.0 & 04.4 & \\
\hline SS & $3 f$ & $\mathrm{x}$ & Center of $\cdots$ & 0.8 & 22.3 & 25.0 & 9.0 & 6.0 & \\
\hline MTom & $3 f^{\prime}$ & 36 Top & 1.3 mi- $\mathrm{SSE}$ of Brightside & 3 & 13.0 & 21.4 & 47.5 & 13.0 & 2.1 \\
\hline $\begin{array}{l}\text { MH } \\
\text { MH } \\
\text { MH } \\
\text { MH } \\
\text { MH } \\
\text { MH } \\
\text { MH }\end{array}$ & $\begin{array}{r}16 a \\
16 c \\
16 e \\
1 a \\
1 c \\
2 a \\
2 c \\
13 a\end{array}$ & $\begin{array}{l}39 \\
36 \\
36 \\
X \\
38 \text { Top } \\
36 \\
38 \text { Top } \\
\text { X Top } \\
38 \text { Top }\end{array}$ & $\begin{array}{l}\text { of Stony Brook (Trib).. } \\
\text { of Stony Brook (Trib). } \\
\text { of Stony Brook (Trib). } \\
\text { S. of Hockanum (FP) } \\
\text { S. of Hockanum (FP) } \\
\text { S. of Hockanum (FP) } \\
\text { S. of Hockanum (FP). } \\
\text { near mouth of Fort } \mathrm{R} \text {. }\end{array}$ & $\begin{array}{r}11.7 \\
13.1 \\
8.6 \\
9.0 \\
14.9 \\
8.4 \\
13.5 \\
16.2\end{array}$ & $\begin{array}{l}36.3 \\
40.6 \\
21.5 \\
23.7 \\
41.3 \\
32.3 \\
38.2 \\
39.2\end{array}$ & $\begin{array}{l}41.1 \\
32.2 \\
.29 .5 \\
32.3 \\
24.4 \\
40.8 \\
33.8 \\
21.0\end{array}$ & $\begin{array}{r}8.5 \\
9.9 \\
24.3 \\
28.9 \\
13.0 \\
14.8 \\
10.8 \\
12.7\end{array}$ & $\begin{array}{r}2.0 \\
3.0 \\
14.8 \\
5.5 \\
5.9 \\
3.2 \\
3.4 \\
10.6\end{array}$ & $\begin{array}{r}.4 \\
1.2 \\
1.3 \\
.6 \\
.5 \\
.5 \\
.3 \\
.3\end{array}$ \\
\hline MH & $13 c$ & 38 Bot. & Bridge near mouth of Fort $R$. & 18.4 & 37.2 & 17.9 & 11.2 & 6.6 & 8.7 \\
\hline MH & $24 \mathrm{f}$ & Pre-36 & $\begin{array}{l}\text { Mill R., } 0.1 \text { mi. downstream } \\
\text { from B.\& M. R.R. bridge }\end{array}$ & 6.6 & 19.3 & 34.3 & 31.7 & 4.2 & 3.9 \\
\hline MT & 11 e & $\mathrm{x}$ & W. end of Piumtree Road & & 9.3 & 19.6 & 37.6 & 30.0 & 1.2 \\
\hline G & $19 \mathrm{~g}$ & $\mathrm{x}$ & Wüw. of Montague & & 12.7 & 12.4 & 33.8 & 30.7 & 3.2 \\
\hline G & $22 \mathrm{Ab}$ & 36 & $0.7 \mathrm{mi}$. NNw. of Fish Hatchery & & 16.9 & 29.8 & 19.6 & 21.2 & 8.6 \\
\hline G & $22 \mathrm{Ff}$ & 36 Bot. & $0.7 \mathrm{mi} . \mathrm{N}$ NWW. of Fish Hatchery & & 43.4 & 16.8 & 7.8 & 13.2 & 7.3 \\
\hline G & $22 \mathrm{Ha}$ & 38 & jNw. of Fish Hatchery & 4.3 & 16.6 & 32.2 & 41.8 & 4.6 & .5 \\
\hline G & $15 \mathrm{~d}$ & 36 Bot. & S: of Rawsons Isiand & 13 & 44.7 & 23.3 & 15.5 & 2.2 & .4 \\
\hline $\mathrm{E}$ & $1 b$ & 38 Mid. & ary isiand & & 28.3 & 49.3 & 16.9 & 1.5 & .2 \\
\hline $\mathbf{E}$ & $\mathbf{5 b}$ & 38 Bot. & $\ddot{0} \ddot{f t} . \ddot{W} . \ddot{*} \ddot{R} . \ddot{R}$. & & 13.1 & 22.3 & 33.1 & 22.5 & 4.2 \\
\hline MTom & $1 \mathrm{~b}$ & 38 Bot. & (TErib) of Holyoke City & & 15.2 & 23.1 & 31.8 & 17.4 & 7.2 \\
\hline MTom & $1 \mathrm{~g}$ & $\mathrm{x}$ & of Holyoke City & & 7.4 & 11.0 & 48.4 & 28.8 & 2.3 \\
\hline & & & & & 9.3 & 9.3 & 33.9 & 1.9 & .3 \\
\hline
\end{tabular}


CONNECTICUT RIVER-Continued

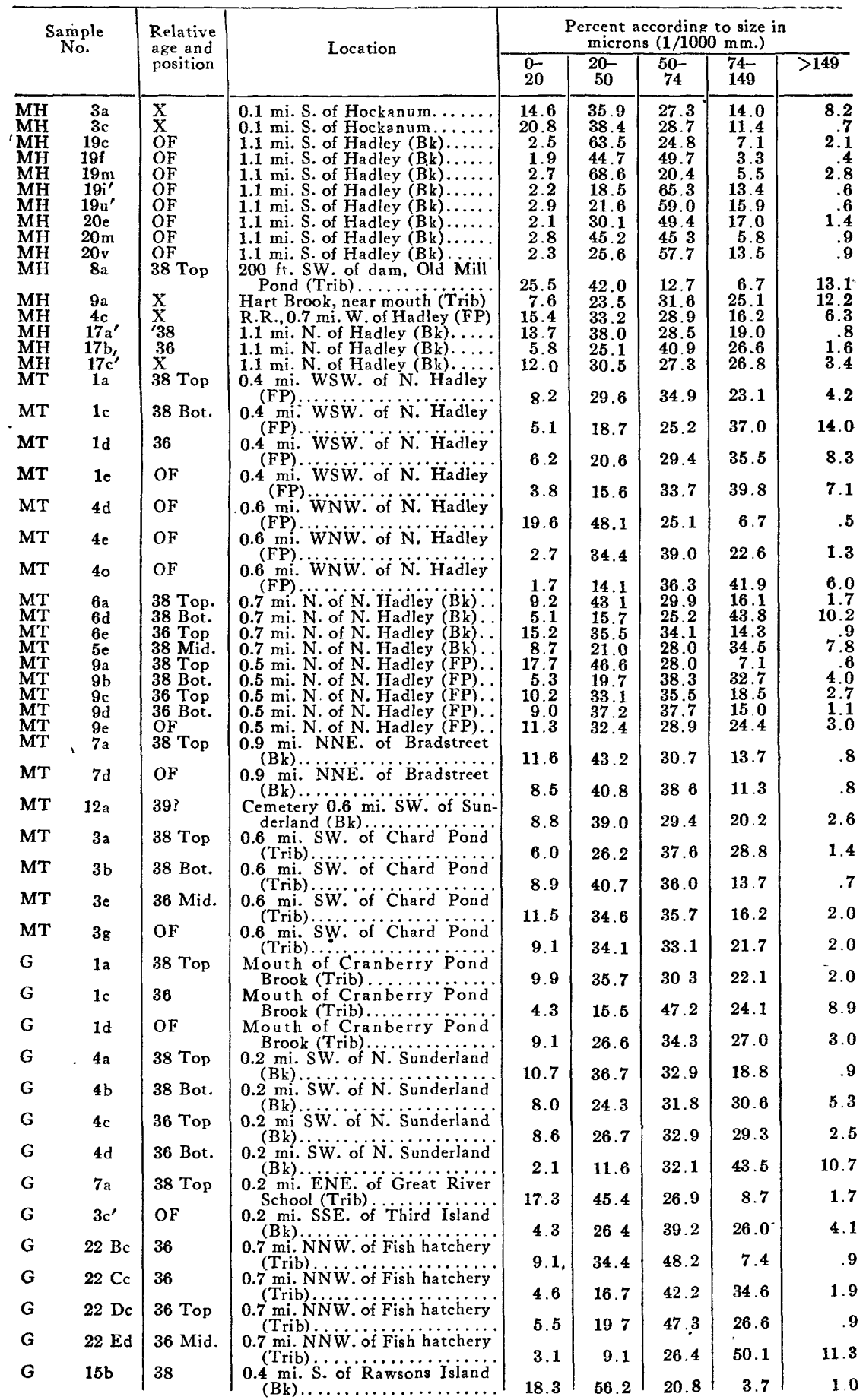


MECHANICAL ANALYSES OF FLOOD SEDIMENTS

CONNECTICUT RIVER-Continued

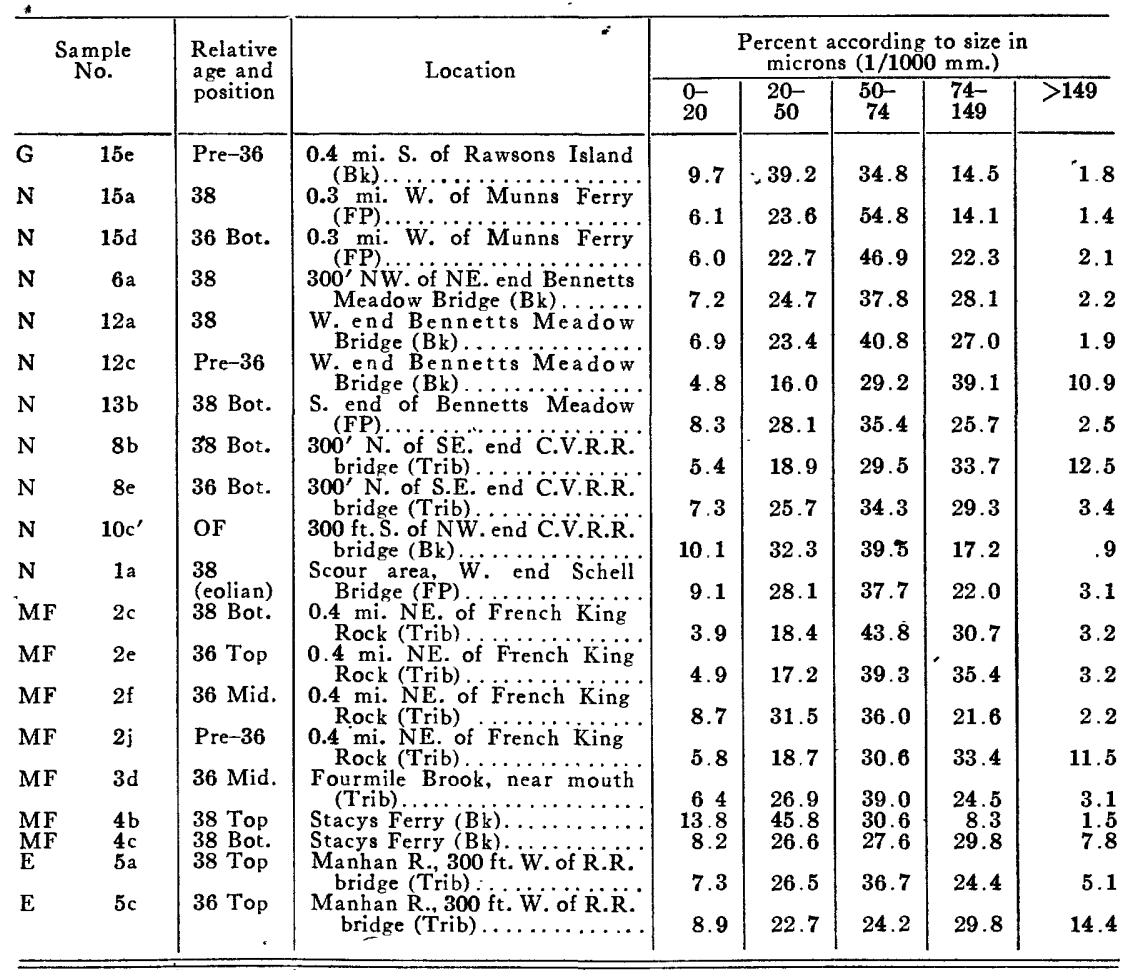

\begin{tabular}{|c|c|c|c|c|c|c|c|c|c|c|c|}
\hline & & & \multicolumn{8}{|c|}{$\begin{array}{l}\text { Percent according to size in } \\
\text { microns }(1 / 1000 \mathrm{~mm} .)\end{array}$} \\
\hline & & & & $\begin{array}{l}0- \\
50\end{array}$ & & $\begin{array}{ll}50- \\
74\end{array}$ & $\begin{array}{l}74- \\
149\end{array}$ & & 297 & $297-$ & $>590$ \\
\hline \multirow{10}{*}{$\begin{array}{l}\text { SS } \\
\text { SS } \\
\text { MH } \\
\text { MH } \\
\text { MT } \\
\text { G } \\
\text { MF } \\
\text { MTom }\end{array}$} & $3 \mathrm{~b}$ & 38 Bot. & Center of N. half of Big Island & \multirow{2}{*}{\multicolumn{2}{|c|}{.2}} & & \multirow[b]{2}{*}{2.7} & \multirow{2}{*}{\multicolumn{2}{|c|}{50.2}} & i & \multirow[b]{2}{*}{.3} \\
\hline & $3 c$ & 36 & Center of $\mathrm{N}$. half of Big Isiand & & & & & & & 46.4 & \\
\hline & $200^{\prime}$ & & (FP) $\ldots$ & .4 & \multirow{2}{*}{\multicolumn{2}{|c|}{$\begin{array}{l}.5 \\
.5\end{array}$}} & 2.0 & \multicolumn{2}{|c|}{36.7} & 59.3 & 1.1 \\
\hline & $8 \mathrm{~b}$ & 38 Mid. & $200 \mathrm{ft}$. SW. of dam, Old Mill & \multirow[b]{2}{*}{3.4} & & & & \multirow{2}{*}{\multicolumn{2}{|c|}{39.7}} & 00.0 & 2.0 \\
\hline & $4 o^{\prime}$ & OF & Pond (Trib) . & & \multicolumn{2}{|r|}{2.5} & 9.0 & & & 37.2 & 8.2 \\
\hline & $22 \mathrm{Fb}$ & 38 Bot. & $0.7 \mathrm{mi}$. N $\mathrm{N} \ddot{\mathrm{W}}$ of Fish $\mathrm{H}_{\mathrm{atch}} \ldots$ & .3 & & .5 & 3.6 & \multicolumn{2}{|c|}{33.3} & 50.9 & 11.4 \\
\hline & $3 \mathrm{~b}$ & 38 Bot & (Trib) $\ldots \ldots \ldots \ldots \ldots \ldots$ & \multicolumn{2}{|c|}{1.3} & 2.5 & 10.9 & \multicolumn{2}{|c|}{43.6} & 28.8 & 12.9 \\
\hline & Do & 0000 & (Trib) $\ldots \ldots \ldots$ & $\mathbf{1 . 5}$ & \multicolumn{2}{|r|}{1.5} & 6.9 & \multicolumn{2}{|c|}{23.0} & 52.5 & 14.6 \\
\hline & 10 & . & Home $(\mathrm{Bk}) \ldots \ldots \ldots \ldots \ldots \ldots$ & 3.3 & \multicolumn{2}{|c|}{10.9} & 28.4 & \multicolumn{2}{|c|}{53.6} & 3.6 & .2 \\
\hline & & & & $\stackrel{0-}{2 Q}$ & $\begin{array}{l}20- \\
50\end{array}$ & 74 & $\begin{array}{l}\text { 74- } \\
\text { 149 }\end{array}$ & $\begin{array}{l}149- \\
297\end{array}$ & $-297-$ & $-590-$ & $>1190$ \\
\hline MH & $13 d$ & 36 Top. & $\begin{array}{l}\text { Bridge near mouth of Fort } \\
\text { River (Trib) } \ldots \ldots \ldots \ldots \ldots \ldots\end{array}$ & 4.4 & 14.8 & $8 \mid 26.3$ & 24.6 & 13.5 & 8.3 & 5.6 & 2.5 \\
\hline G & $13 c$ & & Falls $\mathrm{R}, 0.1 \mathrm{mi}$. from mouth & 45 & 150 & 18 4 & 248 & 179 & f 4 & 70 & -.0 \\
\hline $\mathbf{N}$ & $10 b^{\prime}$ & 36 & $300 \mathrm{ft} . \mathrm{S}$. of NW. end C.V.R.R. & & 72 & 128 & 1- & $=0$ & 73 & 130 & 0.0 \\
\hline & & & & 2.0 & & 12.0 & 202.1 & 27.6 & 7.3 & 33.9 & 5.8 \\
\hline
\end{tabular}


CON NECTICUT RIVER-Continued

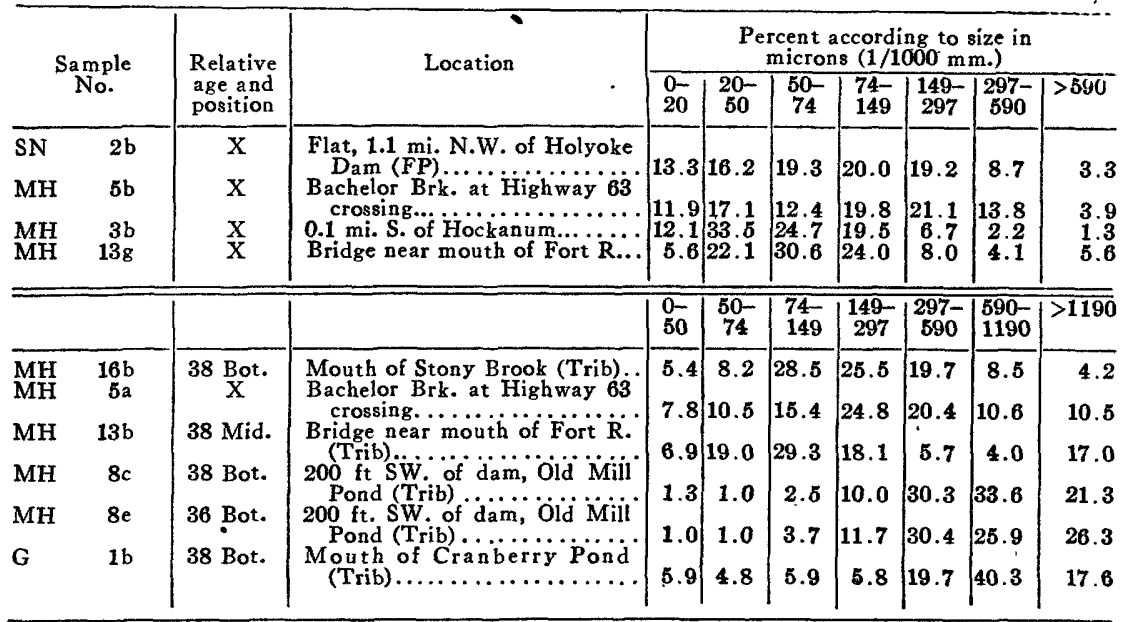

DEGRFIELD RIVER

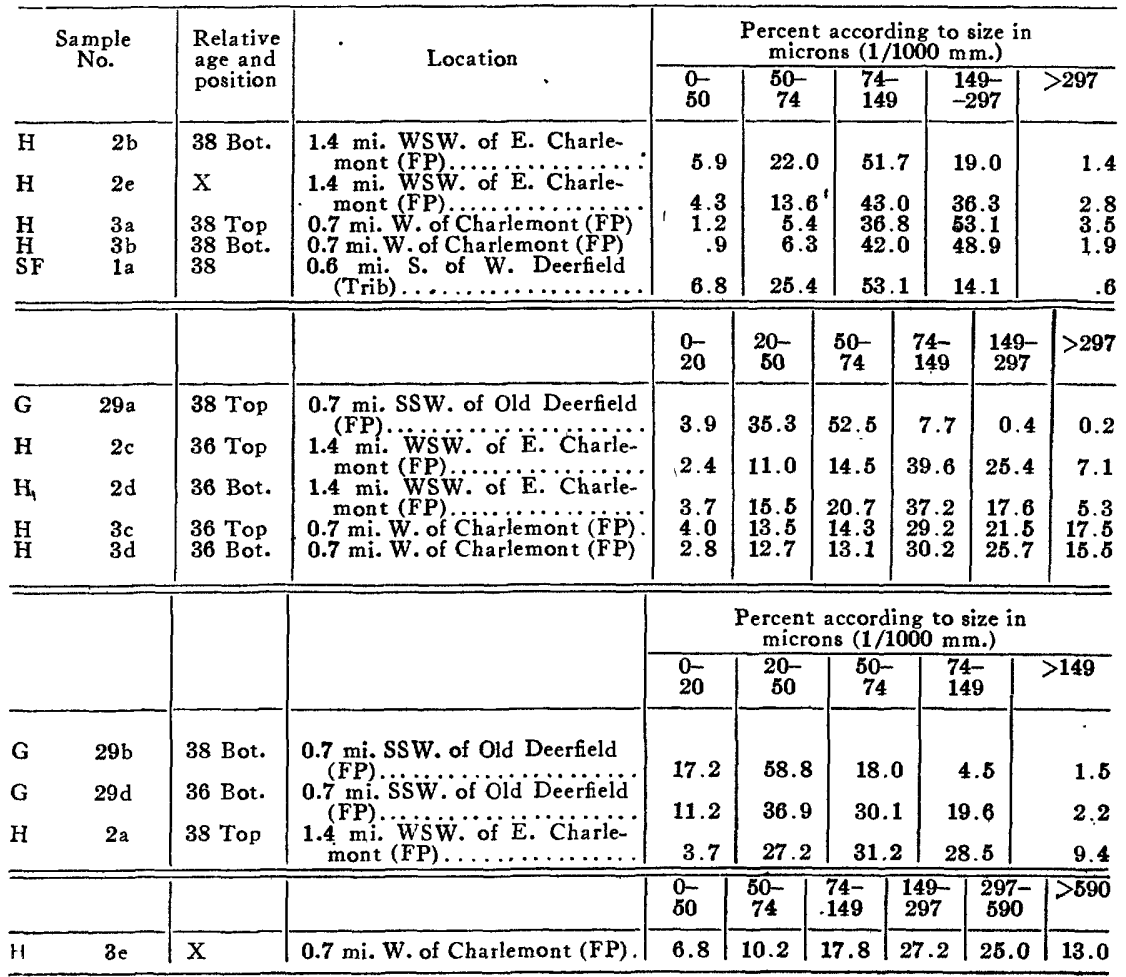


WESTFIELD RIVER

\begin{tabular}{|c|c|c|c|c|c|c|c|c|c|}
\hline \multirow{2}{*}{\multicolumn{2}{|c|}{$\begin{array}{l}\text { Sample } \\
\text { No. }\end{array}$}} & \multirow{2}{*}{$\begin{array}{l}\text { Relative } \\
\text { age and } \\
\text { position }\end{array}$} & \multirow{2}{*}{ Location } & \multicolumn{6}{|c|}{$\begin{array}{l}\text { Percent according to size in } \\
\text { microns }(1 / 1000 \mathrm{~mm} .)\end{array}$} \\
\hline & & & & $\begin{array}{l}0- \\
50\end{array}$ & $\begin{array}{c}50- \\
74\end{array}$ & $\begin{array}{l}74- \\
149\end{array}$ & & & $>297$ \\
\hline \multirow[t]{2}{*}{ Wo } & $2 c$ & 36 & $\begin{array}{l}\text { U.S. Highway } 20 \text { opp. Tekoa } \\
\text { Country Club (FP)........... }\end{array}$ & 8.3 & 25.4 & 53.4 & & .7 & 1.2 \\
\hline & & & & $\stackrel{0}{20}$ & $20-$ & $\stackrel{50-}{74}$ & $\begin{array}{l}74- \\
149\end{array}$ & $\begin{array}{l}149- \\
297\end{array}$ & $>297$ \\
\hline Wo & $2 b$ & 38 Bot. & $\begin{array}{l}\text { U. S. Highway } 20 \text { op. Tekoa } \\
\text { Country Club (FP)......... }\end{array}$ & 6.9 & 36.2 & 29.8 & 10.5 & 16.3 & 0.3 \\
\hline
\end{tabular}

FAN AND RIVER-BAR SAMPLES

\begin{tabular}{|c|c|c|c|c|c|c|c|c|c|c|c|}
\hline \multirow{2}{*}{\multicolumn{2}{|c|}{$\begin{array}{l}\text { Sample } \\
\text { No. }\end{array}$}} & \multirow[b]{2}{*}{ Position } & \multirow[b]{2}{*}{ Locality } & \multicolumn{8}{|c|}{ Percent according to size } \\
\hline & & & & $\begin{array}{c}0- \\
1 \\
m m\end{array}$ & $\mid \begin{array}{c}1 \\
\mathrm{~mm} \\
-2 \\
\mathrm{~mm}\end{array}$ & $\mid \begin{array}{c}2 \\
\mathrm{~mm} . \\
-3 / 8 \\
\text { in. }\end{array}$ & $\left|\begin{array}{l}3 / 8- \\
3 / 4 \\
\text { in. }\end{array}\right|$ & $\left|\begin{array}{c}8 / 4- \\
13 / 2 \\
\text { in. }\end{array}\right|$ & $\begin{array}{c}1 / 1 / 2 \\
3 \\
\text { in. }\end{array}$ & $\begin{array}{l}3- \\
6 \\
\text { in. }\end{array}$ & $\begin{array}{l}>6 \\
\text { in. }\end{array}$ \\
\hline \multirow{4}{*}{$\begin{array}{l}\text { WS } \\
\text { WS } \\
\text { Wo } \\
\text { SN } \\
\text { SF } \\
\text { G } \\
\text { G } \\
\text { G } \\
G \\
G \\
G \\
G \\
G \\
G \\
G \\
\text { G }\end{array}$} & $\begin{array}{l}\mathbf{2} \\
\mathbf{3} \\
\mathbf{3} \mathbf{a}\end{array}$ & $\begin{array}{l}\text { Bar } \\
\text { Bar } \\
\text { Bar }\end{array}$ & $\begin{array}{l}2 \mathrm{mi} . \mathrm{W} \text {. of W. Springfield..... } \\
1.8 \mathrm{mi} \text {. ESE. of Westfield...... } \\
1 \mathrm{mi} \text {. NW. of Tekoa Country }\end{array}$ & $\begin{array}{r}2.6 \\
9.4 \\
\end{array}$ & $\begin{array}{r}1.1 \\
2.0 \\
0\end{array}$ & $\begin{array}{l}3.5 \\
9.4 \\
\end{array}$ & $\begin{array}{r}9.4 \\
11.7\end{array}$ & $\begin{array}{l}21.3 \\
32.5\end{array} \mid$ & $\begin{array}{l}51.3 \\
35.0\end{array}$ & $\begin{array}{r}10.8 \\
.0\end{array}$ & $\begin{array}{r}0.0 \\
.0\end{array}$ \\
\hline & $\begin{array}{l}16 \mathrm{a} \\
4 \\
31 \mathrm{a} \\
31 \mathrm{~b} \\
31 \mathrm{c} \\
31 \mathrm{~d} \\
32 \mathrm{a} \\
\mathbf{3 2 c} \\
\mathbf{3 2 b} \\
\mathbf{3 2 d} \\
33 \mathrm{a} \\
34 \mathrm{a}\end{array}$ & $\begin{array}{l}\text { Bar } \\
\text { Bar } \\
\text { Fan } \\
\text { Fan } \\
\text { Fan } \\
\text { Fan } \\
\text { Bar } \\
\text { Bar } \\
\text { Bar } \\
\text { Bar } \\
\text { Bar } \\
\text { Bar }\end{array}$ & 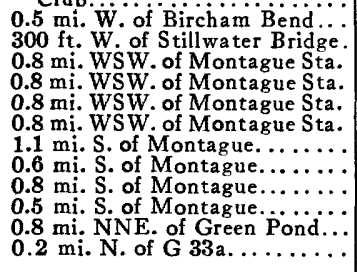 & $\begin{array}{r}8.0 \\
7.6 \\
6.0 \\
16.0 \\
32.3 \\
43.7 \\
2.3 \\
9.8 \\
3.4 \\
27.1 \\
19.3 \\
19.1\end{array}$ & \begin{tabular}{r|}
2.9 \\
3.6 \\
2.2 \\
5.1 \\
4.9 \\
8.2 \\
1.3 \\
3.0 \\
.9 \\
3.7 \\
3.1
\end{tabular} & $\mid \begin{array}{r}6.7 \\
7.5 \\
6.9 \\
19.0 \\
18.7 \\
25.2 \\
4.2 \\
12.4 \\
6.3 \\
24.2 \\
10.8 \\
10.8\end{array}$ & $\mid \begin{array}{r}8.3 \\
8.3 \\
8.3 \\
21.0 \\
18.4 \\
17.8 \\
3.7 \\
15.4 \\
11.3 \\
26.1 \\
11.6 \\
11.9\end{array}$ & $\begin{array}{r}14.0 \\
27.6 \\
16.5 \\
31.9 \\
25.7 \\
5.1 \\
7.3 \\
32.0 \\
19.4 \\
18.9 \\
1.1 \\
24.8\end{array}$ & $\mid \begin{array}{r}00.7 \\
19.0 \\
45.4 \\
15.6 \\
7.0 \\
.0 \\
.0 \\
17.3 \\
27.4 \\
21.5 \\
.0 \\
7.8 \\
29.8\end{array}$ & $\left|\begin{array}{r}40.9 \\
44.5 \\
.0 \\
.0 \\
.0 \\
63.9 \\
.0 \\
37.2 \\
.0 \\
53.7 \\
.0\end{array}\right|$ & $\begin{array}{r}.0 \\
.0 \\
.0 \\
.0 \\
.0 \\
.0 \\
.0 \\
.0 \\
.0 \\
.0 \\
35.8 \\
.0\end{array}$ \\
\hline & & & W. end of Schell Bridge. ..... & 11.9 & 7.9 & 27.6 & 26.2 & 26.4 & .0 & .0 & 0 \\
\hline & & & - & $\begin{array}{l}0- \\
.074 \\
\mathrm{~mm}\end{array}$ & $\mid \begin{array}{c}.074 \\
\mathrm{~mm} . \\
- \\
.147 \\
\mathrm{~mm} .\end{array}$ & $\begin{array}{c}.147 \\
\mathrm{~mm} . \\
.295 \\
\mathrm{~mm} .\end{array}$ & $\mid \begin{array}{c}295 \\
\mathrm{~mm} . \\
\overline{589} \\
\mathrm{~mm} .\end{array}$ & $\mid \begin{array}{c}589 \\
\mathrm{~mm} . \\
\overline{1} \\
\mathrm{~mm} .\end{array}$ & $\mid \begin{array}{c}1 \\
\mathrm{~mm} . \\
\overline{2} \\
\mathrm{~mm} .\end{array}$ & \begin{tabular}{|c|}
2 \\
$\mathrm{~mm}$. \\
$3 / 8$ \\
in.
\end{tabular} & $73 / 8$ \\
\hline G & $\begin{array}{l}32 \mathrm{~s} \\
34 \mathrm{~b}\end{array}$ & $\begin{array}{l}\text { Bar } \\
\text { Bar }\end{array}$ & $\begin{array}{l}0.4 \mathrm{mi} . \text { SSE. of Montague } \ldots \ldots \\
0.4 \mathrm{mi} \text {. N. of } \mathrm{G} 33 \mathrm{a} . \ldots \ldots \ldots \ldots\end{array}$ & $\begin{array}{l}4.3 \\
5.7\end{array}$ & $\begin{array}{r}9.1 \\
10.7\end{array}$ & $\mid \begin{array}{r}15.6 \\
8.8\end{array}$ & 23.9 & 24.4 & $\begin{array}{r}9.5 \\
18.9\end{array}$ & $\left|\begin{array}{l}10.0 \\
16.4\end{array}\right|$ & $\begin{array}{l}32 \\
5.3\end{array}$ \\
\hline
\end{tabular}




\section{REFERENCE ISTS}

None of the following reference lists purports to be complete. All works cited individually are either of significant general interest or bear directly on the foregoing report. Many other references are included in the bibliographies that appear as a separate group in the following lists. For the convenience of the investigator, references are classified according to subject material.

\section{BEDROCK GEOLOGY OF CENTRAL WESTERN MASSACHUSETTS AND CONNECTICUT}

Bain, G. W., The Triassic of northern Massachusetts: Am. Jour. Sci., 5th ser., vol. 23, pp. 57-77, 1932.

Barrell, Joseph, Central Connecticut in the geologic past: Connecticut Geol. and Nat. History Survey Bull. 23, 1915.

Dana, E. S., On the trap rocks of the Connecticut Valley: Am. Jour. Sci., 3d ser., vol. 8, pp. 390-392, 1874 .

Davis, W. M., The structure of the Triassic formation in the Connecticut Valley: U. S. Geol. Survey, 7th Ann. Report, pp. 455-490, 1887.

Davis, W. M., and Whittle, C. L., The intrusive and extrusive Triassic trap sheets of the Connecticut Valley: Harvard Coll., Mus. Comp. Zoology Bull., vol. 16. 1889 .

Davis, W. M., The Triassic formation of Connecticut: U. S. Geol. Survey, 18th Ann. Report, pt. 2, pp. 1-192, 1898.

Emerson, B. K., Geology of old Hampshire County, Mass.: U. S. Geol. Survey Mon. 29, 1898.

Emerson, B. K., U. S. Geol. Survey Geol. Atlas, Holyoke Folio (no. 50), 1898.

Emerson, B. K., Geology of Massachusetts and Rhode Island: U. S. Geol. Survey Bull. 597, pp. $15-17,19-24,32-34,40-48$, 59-76, 89-104, 127-132, 150-155, 208 217, 241-258, 261-272, 1917.

Longwell, C. R., Eastern New York and western New England: Int. Geol. Cong., XVI session, Guidebook I: Excursion A-1, .pp. 61-62, 93-101, 105-110, 1933.

Loomis, F. B., Postglacial faulting about Mount Toby, Mass.: Geol. Soc. America Bull., vol. 32, pp. 75-80, 1921.

Lull, R. S., Triassic life of the Connecticut Valley: Connecticut Geol. and Nat. History Survey Bull. 24, 1915.

Lull, R. S., The Triassic fauna and flora of the Connecticut Valley, in Emerson, B. K., Geology of Massachusetts and Rhode Island: U. S. Geol. Survey Bull. 597, pp. 105-127, 1917.

Miller, W. J., The geological history of the Connecticut Valley of Massachusetts, The Hampshire Bookshop, Inc., Northampton, Mass., 1921.

Wheeler, Girard, The west wall of the New England Triassic lowland: Connecticut Geol. and Nat. History Survey Bull. 58, 1937.

Wheeler, Girard, Triassic fault-line deflections and associated warping: Jour. Geology, vol. 47, pp. 337-370, 1939. 


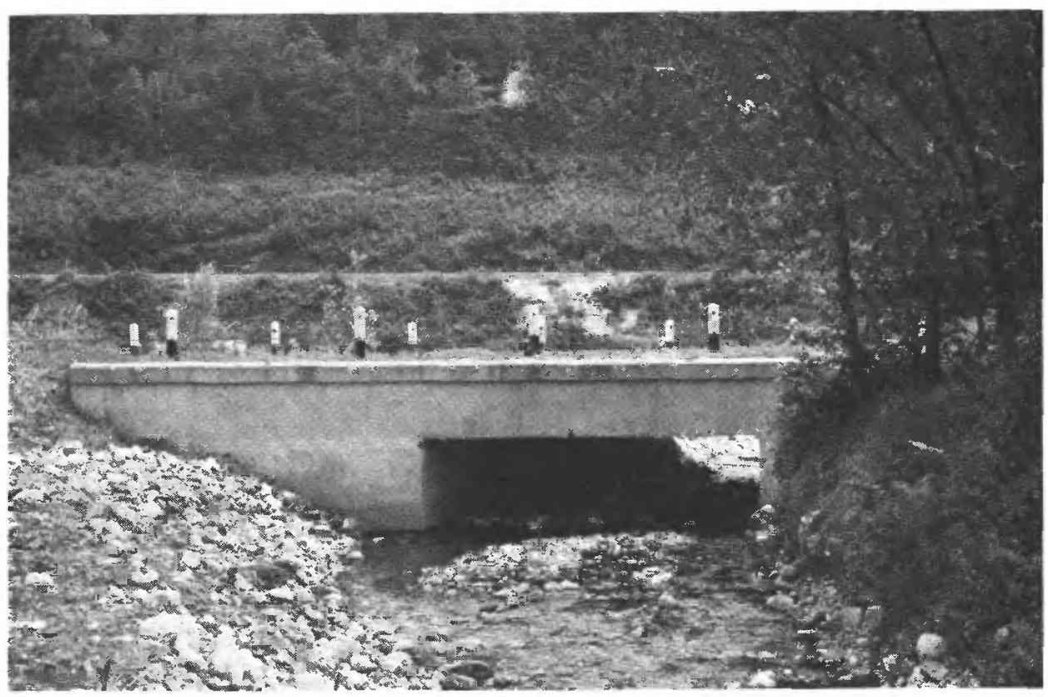

A. SMALL HIGHWAY BRIDGE THAT BECAME CHOKED WITH DEBRIS DURING FLOODS OF MARCH 1936 AND SEPTEMBER 1938.

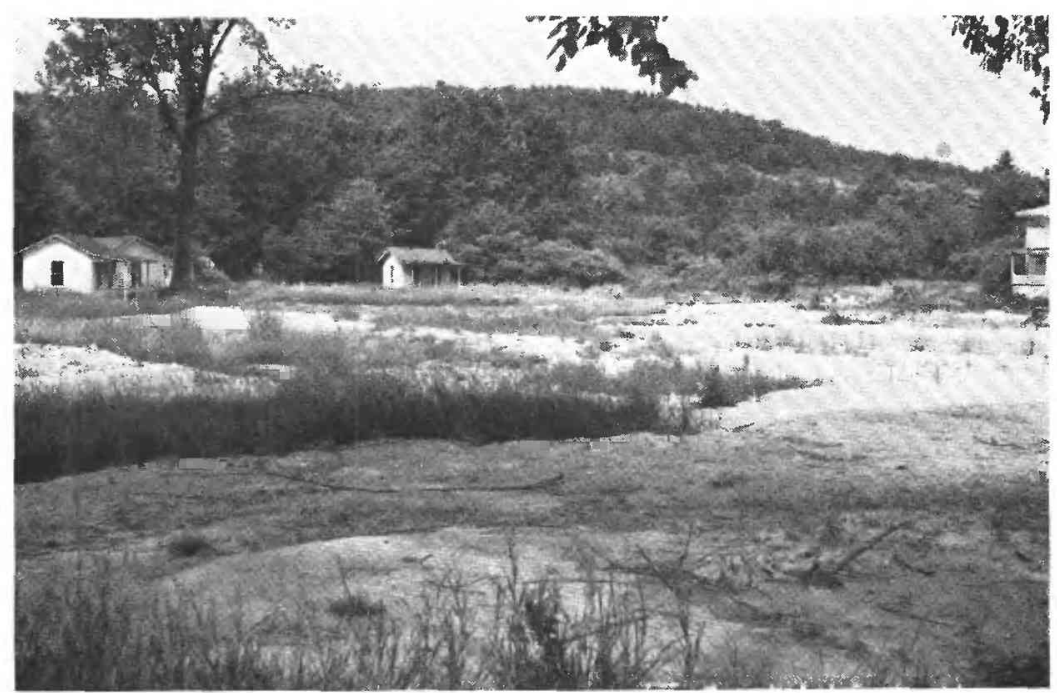

B. THICK SAND DEPOSITS FORMED BY WATERS OF BROOK DURING BY-PASSING OF CLOGGED HIGHWAY BRIDGE.

FLOOD CONDITIONS ON LOWER AVERY BROOK, WEST OF EAST CHARLEMONT. 


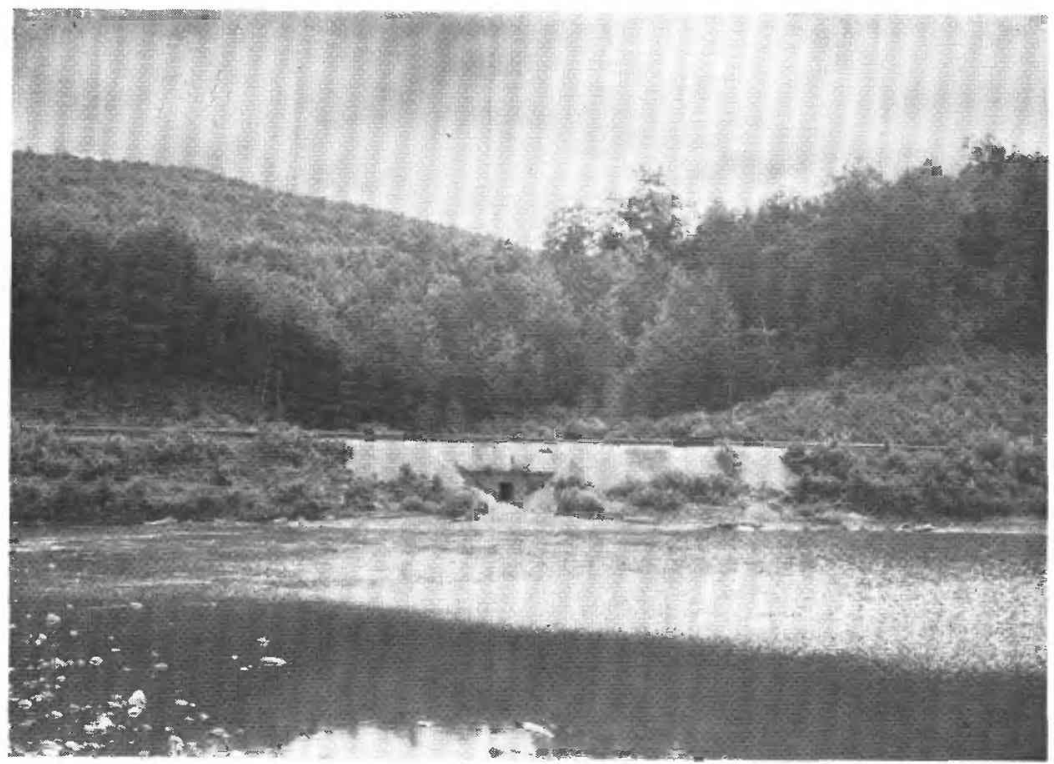

A. SMALL RAILROAD CULVERT, DEERFIELD RIVER.

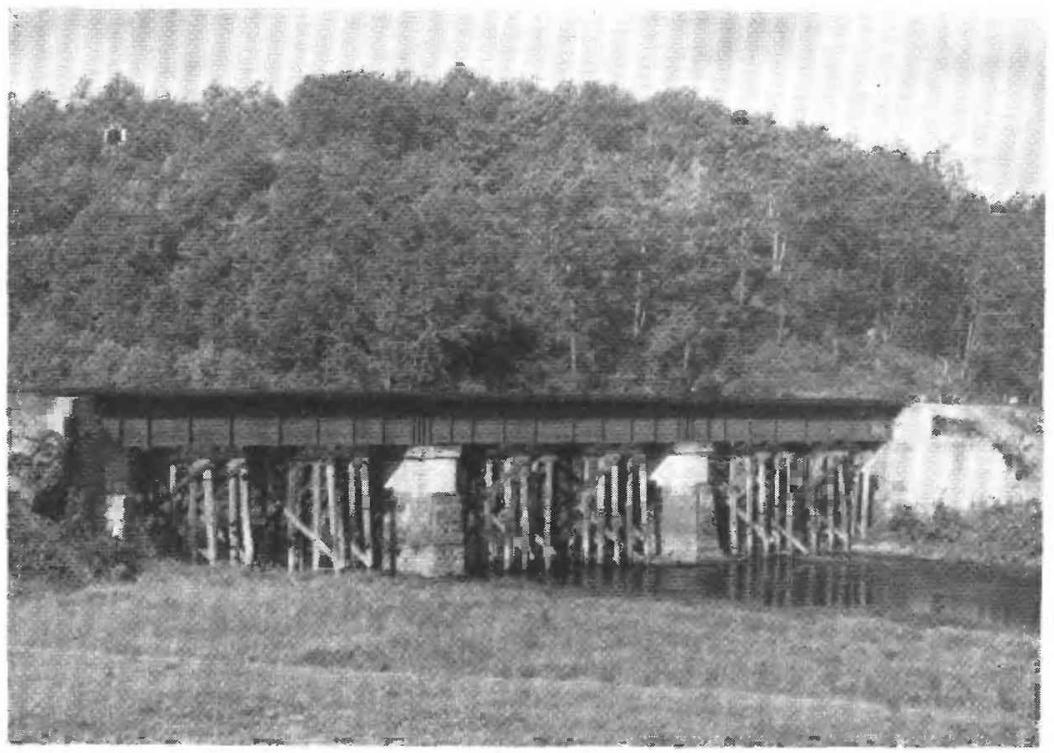

B. FALSE WORK UNDER RAILROAD BRIDGE OVER QUABOAG RIVER, SOUTH OF THREE RIVERS.

BRIDGE STRUCTURES SUBJECT TO FLOOD DAMAGE. 


\section{QUATERNARY GEOLOGY OF NEW ENGLAND AND RELATED REGIONS}

Alden, W. C., The physical features of central Massachusetts: U. S. Geol. Survey Bull. 760, 1924.

Antevs, Ernst, The recession of the last ice sheet in New England: Am. Greog. Soc., Research ser. (no. 11), 1922.

Antevs, Ernst, Retreat of the last ice sheet in eastern Canada: Canada Geol. Survey, Mem. 146, 1925.

Antevs, Ernst, The last glaciation, with special reference to the ice retreat in Northeastern North America: Am. Geog. Soc., Research ser. (no. 17), 1928.

Antevs, Ernst, Late Quaternary changes of level in Maine: Am. Jour. Sci., 5th ser., vol. 15, pp. 319-336, 1928.

Antevs, Ernst, Modes of retreat of the Pleistocene ice sheets: Jour. Geology, vol. 47, pp. 503-508, 1939 .

Baldwin, S. P., Pleistocene history of the Champlain Valley: Am. Geologist, vol. 13, pp. 170-184, 1894.

Barrell, Joseph, Factors in the movements of the strand line and their results in the Pleistocene and post-Pleistocene: Am. Jour. Sci., 4th ser., vol. 40, pp. 1-22, 1915.

Baulig, Henri, The changing sea level: Four lectures given at the University of London in November, 1933: Inst. British Geographers Pub. (no. 3), 1935.

Brown, T. C., Glacial lakes and ice movements in Millers River Valley, Massachusetts (abstract) : Geol. Soc. America Bull., vol. 44, pp. 74-75, 1933.

Brown, T. C., The waning of the last ice sheet in central Massachusetts: Jour. Geology, vol. 41, pp. 144-158, 1933.

Brown, T. C., History of the Nashua and Millers River Valleys in late Wisconsin time (abstract): Geol. Soc. America Proc., 1933, p. 70, 1934.

Brown, T. C., Evidence of stagnant ice in glacial lakes Hadley and Montague in the Connecticut Valley (abstract): Geol. Soc. America Proc., 1933, p. 450, 1934.

Chalmers, Robert, Notes on the Pleistocene marine shore lines and landslips of the north side of the St. Lawrence Valley: Canada Geol. Survey, Ann. Rept., new ser., vol. 11, pp. 63J-70J, 1901.

Daly, R. A., Oscillations of level in the belts peripheral to the Pleistocene ice caps: . Geol. Soc. America Bull., vol. 31, pp. 303-318, 1920.

Daly, R. A., Pleistocene changes of level: Am. Jour. Sci., 5th ser, vol. 10, pp. 281-313, 1925.

Dana, J. D., Note on river terraces: Am. Jour. Sci., 3d ser., vol. 2, pp. 144-145, 1871.

Dana, J. D., On the Connecticut River Valley glacier and other examples of glacier movement along the valleys of New England:. Am. Jour. Sci., 3d ser., vol. 2, pp. 233-243, 1871.

Dana, J. D., On the glacial and Champlain eras in New England: Am. Jour. Sci., 3d ser., vol. 5, pp. 198-211, 217-218, 219, 1873.

Dana, J. D., On southern New England during the melting of the great glacier: Am. Jour. Sci., 3d ser., vol. 10, pp. 168-183, 280-282, 353-357, 409-438, 497-508, 1875.

Dana, J. D., On the relation of the so-called "kames" of the Connecticut River Valley to the terrace formation: Am. Jour. Sci., 3d ser., vol. 22, pp. 4j1-468, 1881. 
Dana, J. D., The flood of the Connecticut River Valley from the melting of the Quaternary glacier: Am. Jour. Sci., 3d ser., vol. 23, pp. 87-97, 179-202, 360373 ; vol. 24, pp. 98-104, 1882.

Dana, J. D., Long Island Sound in the Quaternary era, with observations on the submarine Hudson River channel: Am. Jour. Sci., 3d ser., vol. 40, pp. 425-437, 1890.

Davis, W. M., The terraces of the Westfield River, Mass.: Am. Jour. Sci., 4th ser., vol. 14, pp. 77-94, 1902.

Davis, W. M., River terraces in New England: Harvard Coll., Mus. Comp. Zoology Bull., vol. 38, pp. 281-346, 1902.

DeGeer, Gerard, On Pleistocene changes of level in eastern North America: Boston Soc. Nat. History Proc., vol. 25, pp. 454-477, 1892; Am. Greologist, vol. 11, pp. 22-44, 1893.

Emerson, B. K., The Connecticut lake of the Champlain period, north of Holyoke: Am. Jour. Sci., 3d ser., vol. 34, pp. 404-405, 1887.

Emerson, B. K., Geology of old Hampshire County, Mass.: U. S. Geol. Survey Mon. 29, pp. 508-752, 1898.

Fairchild, H. L., Pleistocene geology of New York State: Geol. Soc, America Bull., vol. 24, pp. 133-162, 1913.

Fairchild, H. L., Pleistocene marine submergence of the Connecticut and Hudson Valleys: Geol: Soc. America Bull., vol. 25, pp. 63-65, 219-242, 1914.

Fairchild, H. L., Postglacial uplift of northeastern America: Geol. Soc. America Bull., vol. 29, pp. 187-238, 1918.

Fairchild, H. L., Postglacial uplift of southern New England: Geol. Soc. America Bull., vol. 30, pp. 597-636, 1919.

Flint, R. F., The stagnation and dissipation of the last ice sheet: Geog. Rev., vol. 19, pp. 256-289, 1929.

Flint, R. F., The glacial geology of Connecticut: Connecticut Geol. and Nat. History Survey, Bull. 47, 1930.

Flint, R. F., Terraces in the Connecticut Valley: Science, new ser., vol. 74, pp. 368-369, 1931.

Flint, R. F., Deglaciation in the Connecticut Valley: Am. Jour. Sci., 5th ser., vol. 24, pp. 152-156, 1932.

Flint, R. F., Late Pleistocene sequence in the Connecticut Valley: Geol. Soc. America Bull., vol. 44, pp. 965-988, 1938.

Flint, R. F., Late-glacial features of the Quinnipiac-Farmington lowland in Connecticut: Am. Jour. Sci., 5th ser., vol. 27, pp. 83-91, 1934.

Goldthwait, J. W., Isobases of the Algonquin and Iroquois beaches, and their significance: Geol. Soc. America Bull., vol. 21, pp. 227-248, 1910.

Goldthwait, J. W., An instrumental survey of the shore lines of extinct lakes Algonquin and Nipissing, in southwestern Ontario: Canada Geol. Survey, Mem. 10, 1910.

Goldthwait, J. W., Raised beaches of southern Quebec: Canada Geol. Survey, Summary Rept., 1910, pp. 220-233, 1911.

Goldthwait, J. W., The Twenty-foot terrace and sea-cliff of the lower St. Lawrence: Am. Jour. Sci., 4th ser., vol. 32, pp. 291-317, 1911.

Goldthwait, J. W., The uncovering of New Hampshire by the last ice sheet: Am. Jour. Sci., 5th ser., vol. 36, pp. 345-372, 1938.

Gulliver, F. P., Thames River terraces in Connecticut (abstract) : Geol. Soc. America Bull., vol. 10, pp. 492-495, 1900. 
Hatch, Laura, Marine terraces in southeastern Connecticut: Am. Jour. Sci., 4th ser., vol. 44, pp. 319-330, 1917.

Hitchcock, Edward, On the river terraces of the Connecticut Valley, and on the erosions of the earth's surface: Am. Assoc. Adv. Sci. Proc., vol. 2, pp. 148-156, 1850.

Horner, N. G., Late glacial marine limit in Massachusetts: Am. Jour. Sci., 5th ser., , vol. 17. pp. 123-145, 1929.

Jefferson, M. S. W., The postglacial Connecticut at Turners Falls : Jour. Geology, vol. 6 , pp. $463-472,1898$.

Johnson, Douglas, The New England-Acadian shore line, New York, John Wiley and Sons, Inc., 1925.

Johnson, Douglas, The changing sea level: A review and discussion: Geog. Rev., vol. 26, pp. 299-301, 1936.

Johnston, W. A., Late-Pleistocene oscillations of sea level in the Ottawa Valley: Canada Geol. Survey, Mus. Bull. 24, 1916.

Leverett, Frank, Outline of the history of the Great Lakes: Michigan Acad. Sci., 12th Ann. Rept., pp. 19-42, 1910.

Leverett, Frank, and Taylor, F. B., The Pleistocene of Indiana and Michigan and the history of the Great Lakes: U. S. Geol. Survey Mon. 53, 1915.

Peet, C. E., Glacial and postglacial history of the Hudson and Champlain Valleys : Jour. Geology, vol. 12, pp. 415-469, 617-660, 1904.

Sharp, H. S., Physical history of the Connecticut shore line: Connecticut Geol. and Nat. History Survey Bull. 46, 1929.

Stanley, G. M., Lower Algonquin beaches of the Penetanguishene Peninsula: Geol. Soc. America Bull., vol. 47, pp. 1934-1958, 1936.

Stone, G. H., The glacial gravels of Maine and their associated deposits: U. S. Geol. Survey Mon. 34, pp. 54-58, 1899.

Upham, Warren, The Champlain submergence (abstract): Geol. Soc. America Bull., vol. 3, pp. 508-511, 1892.

Upham, Warren, The Champlain submergence (review): Am. Geologist, vol. 11, p. $119,1893$.

Ward, Freeman, The Quaternary geology of the New Haven region, Conn: Connecticut Geol. and Nat. History Survey, Bull. 29, 1920.

Woodworth, J. B., Ancient water levels of the Champlain and Hudson Valleys: New York State Mus. Bull. 84, 1905.

\section{METEOROLOGY AND HYDROLOGY OF NEW ENGLAND FLOODS}

Brooks, C. F., and Thiessen, A. H., The meteorology of great floods in the eastern United States: Geog. Rev., vol. 27, pp. 269-290, 1937.

Brooks, C. F., Hurricanes into New England; meteorology of the storm of September 21, 1938: Geog. Rev., vol. 29, pp. 119-127, 1939.

Byers, H. R., Meteorological conditions during the March 1936 and other notable floods: Am. Meteorol. Soc. Bull., vol. 18, no. 3, 1937.

Francis, J. B., Distribution of rainfall during the great storm of October 3 and 4, 1869: Am. Soc. Civil Eng., Trans., pp. 224-235, 1878.

Goldthwait, J. W., The gathering of floods in the Connecticut River system: Geog. Rev., vol. 18, pp. 428-445, 1928.

Goodnough, X. H., Rainfall in New England during the storm of November 3 and 4, 1927: Assoc. Jour., New England Water Works, vol. 42, pp. 150-187, 1928. 
Gregg, W. R., Forecasting flood flows: Eng. News Rec., vol. 118, pp. 198-199, 1937. Grover, N. C., The floods of March, 1936; part 1, New England rivers: U. S. Geol. Survey Water-Supply Paper 798, 1937.

Kinnison, H. B., The New England flood of November 1997: U. S. Geol. Survey Water-Supply Paper 636, pp. 45-100, 1930.

Kinnison, H. B., Conover, L. F., and Bigwood, B. L., Stages and flood discharges of the Connecticut River at Hartford, Conn.: U. ,S. Geol. Survey Water-Supply Paper 836, 1938.

Lichtblat, Stephen. Weather associated with the floods of March, 1936, in Grover, N. C., The floods of March, 1936, part 3: Potomac, James, and upper Ohio Rivers; U. S. Geol. Survey Water-Supply Paper 800, pp. 12-31, 1937.

Massachusetts Geodetic Survey, High water data, flood of March 1936, in Massa. chusetts, Massachusetts Dept. Pub. Works, Boston, 1936.

Massachusetts Geodetic Survey, High water data, floods of March 1936, and Sep. tember 1938, in Massachusetts, Massachusetts Dept. Pub. Works, Boston, 1939

Massachusetts State Planning Board, Report on state planning for Massachusetts, 1936.

Massachusetts State Planning Board, drainage basin study no. 2, Connecticut River, 1938.

New England Regional Planning Commission, Water resources of New England, Pub. no. 5.1, 1937.

Pierce, C. H., Flood flows of New England rivers: Boston Soc. Civil Eng. Jour., vol. 11, pp. $327-375,1924$.

Pierce, C. H., The meteorological history of the New England hurricane of September 21, 1938: Monthly Weather Rev., vol. 67, pp. 237-285, 1939.

Tannehill, I. R., Hurricane of September 16 to 22, 1938: Monthly Weather Rev., vol. 66 , pp. 286-288, 1938.

Uhl, W. F., Flood conditions in New England: Am. Soc. Civil Eng. Proc., pp. 449-483, 1937.

U. S. Engineer Department, Connecticut River, Comm., Mass., N. H., and Vt., 7tth Congress, 2nd Session, H. D. 412, Washington, 1936.

\section{GEOGRAPHY, METEOROLOGY, AND HYDROLOGY OF UNITED STATES FLOODS (New England floods excluded)}

Anonymous, The floods of March 1936 in Pennsylvania, Pennsylvania Dept. Forests and Waters, 1936.

Dalrymple, Tate, and others, Major Texas floods of 1936: U. S. Geol. Survey Water-Supply Paper 816, 1937.

Dalrymple, Tate, and others, Floods in the Canadian and Pecos River Basins, N. Mex., 1937: U. S. Geol. Survey Water-Supply Paper 842, 1939.

Follansbee, Robert, and Spiegel, J. B., Flood on Republican and Kansas Rivers, May and June 1935: U. S. Geol. Survey Water-Supply Paper 796-B, 1937.

Grover, N. C., andi others, The floods of March 1936, part 2 : Hudson River to Susquehanna River region: U. S. Geol. Survey Water-Supply Paper 799, 1937.

Grover, N. C., and others, The floods of March 1936, part 3 : Potomac, James, and upper Ohio Rivers: U. S. Geol. Survey Water-Supply Paper 800, 1937.

Grover, N. C., and others, Floods of Ohio and Mississippi Rivers, JanuaryFebruary 1937: U. S. Geol. Survey Water-Supply Paper 838, 1938. (With a section on the flood deposits of the Ohio River by G. R. Mansfield.) 
Breeding, S. D. and Dalrymple, Tate, Texas Floods of 1938 and 1939: U. S. Geol. Survey Water-Supply Paper 914, 1944.

Harrington, A. W., and Johnson, H., The New York floods of 1935 and 1936: Am. Soc. Civil Eng. Proc., vol. 63, 1937.

Hoyt, W. G., and others, Studies of relations of rainfall and runoff in the United States: U. S. Geol. Survey Water-Supply Paper 772, 1936.

Hoyt, W. G., and Langbein, W. B., Some general observations of physiographic and climatic influences on floods: Am. Geophys. Union Trans., 20th Ann. Meeting, 1939, pt. 2, pp. 166-174, Nat. Research Council, 1939.

Jarvis, C. S., and others, Floods in the United States, magnitude and frequency: U. S. Geol. Survey Water-Supply Paper 771, 1936.

Johnson, Hollister, The New York State flood of July 1935: U. S. Geol. Survey Water-Supply Paper 773-E, 1936.

McGlashan, H. D., and Briggs, R. C., Floods of December 1937 in northern California: U. S. Geol. Survey Water-Supply Paper 843, 1939.

Office of Land Use Coordination, The land in flood control: U. S. Dept. Agr. Misc.. Pub. 331, 1938.

Paulsen, C. G., and others, The hurricane floods of September 1938: U. S. Geol. Survey Water-Supply Paper 867, 1940.

Troxell, H. C., and Peterson, J. Q., Flood in La Cañada Valley, Calif., January 1. 1934: U. S. Geol. Survey Water-Supply Paper 796-C, 1937.

Troxell, H. C., and others, Floods of March 1938 in southern California: U. S. Geol. Survey Water-Supply Paper 814, 1942 [1943].

Youngquist, C. V., and Langbein, W. B., Flood of 1935 in the Muskingum River Basin: U. S. Geol. Survey Water-Supply Paper 869, 1941.

\section{/ SHEET, GULLY, AND RIVER-CHANNEL EROSION}

Ball, J. R., The intercision of Pike River, near Kenosha, Wis.: Illinois State Acad. Sci. Trans., vol. 13, pp. 323-326, 1920.

Bay, J. W., Abandoned channels of the lower Huron River, Mich.: Michigan Acad. Sci. Papers, vol. 20, pp. 435-438, 1925.

Bennett, H. H., A permanent loss to New England: soil erosion resulting from the hurricane: Geog. Rev., vol. 29, pp. 196-204, 1939.

Blackwelder, Eliot, Grooving of rock surfaces by sand-laden currents (abstract) : Geol. Soc. America Bull., vol. 44, p. 167, 1933.

Bowman, Isaiah, Deflection of the Mississippi: Science, new ser., vol. 20, pp. 273277, 1904.

Bryan, Kirk, Historic evidence on changes in the channel of Rio Puerco, a tributary to the Rio Grande in New Mexico: Jour. Geology, vol. 36, pp. 265-282, 1928.

Cole, W. S., Modification of incised meanders by floods: Jour. Geology, vol. 45 , pp. 648-654, 1937.

Collins, R. F., and Shalk, Marshall, Torrential flood erosion in the Connecticut Valley, March 1936: Am. Jour. Sci., 5th ser., vol. 34, pp. 293-307, 1937.

Fairchild, H. L., Earth rotation and river erosion: Science, new ser., vol. 76, pp. 423-427, 1932.

Fairchild, H. L., River deflection, a correction: Science, new ser., vol. 76, p. 625, 1982. 
Gilbert; G. K., The sufficiency of terrestrial rotation for the deflection of streams : Am. Jour. Sci., 3d ser., vol. 27, pp. 427-432, 1884.

Goldthwait, J. W., Intercision, a peculiar kind of modification of drainage: School Sci. and Math., vol. 8, pp. 129-139, 1908.

Ireland, H. A., Sharpe, C. F. S., and Eargle, D. H., Principles of gully erosion in the Piedmont of South Carolina: U. S. Dept. Agr. Tech. Bull. 633, 1939.

King, P. B., Corrosion and corrasion on Barton Creek, Austin, Tex. : Jour. Geology, vol. 35 , pp. $631-638,192$ T.

Leighly, John, Meandering arroyos of the dry southwest: Geog. Rev., vol. 26, pp. 270-282, 1936.

Lugeon, Maurice, Le striage du lit fluvial : Ann. de Geographie, vols. 23-24, pp. 385393, 1914-15.

Macar, P. F., Effects of cut-off meanders on the longitudinal profiles of rivers: Jour. Geology, vol. 42, pp. 535-536, 1934.

Maxson, J. H., and Campbell, Ian, Stream fluting and stream erosion: Jour. Geology, vol. 43, pp. 729-744, 1935.

Ramser, C. E., Erosion and silting of dredged drainage ditches: U. S. Dept. Agr., Tech. Bull. 184, 1930.

Shaub, B. M., The origin of cone-in-cone and its bearing on the origin of concretions and septaria : Am. Jour. Sci., 5th ser., vol. 34, pp. 331-344, 1937.

Straub, L. G., Effect of channel-contraction works upon regimen of movable-bed streams: Am. Geophys. Union Trans., 15th Ann. Meeting, 1934, pt. 2, pp. 454463, Nat. Research Council, 1934.

Thomas, B. F., and Watt, D. A., The improvement of rivers, New York, John Wiley and Sons, Inc., 1913.

Thwaites, A. M., Recent stream intercision: Jour. Geology, vol. 39, pp. 653-654, 1931.

Tiffany, J. B., Jr., and Nelson, G. A., Studies of meandering of model-streams: Am. Geophys. Union Trans., 20th Ann. Meeting, pt. 4, pp. 644-649, Nat. Research Council, 1939.

\section{FLUVIAL TRANSPORTATION OF SEDIMENT}

Einstein, H. A., Anderson, A. G., and Johnson, J. W., A distinction between bed load and suspended load in natural streams: Am. Geophys. Union Trans., 21st Ann. Meeting, 1940, pt. 2, pp. 628-633, Nat. Research Council, July 1940.

Flick, L. R., Records of silt carried by the Rio Grande and its accumulation in Elephant Butte Reservoir: Am. Geophys. Union Trans., 15th Ann. Meeting, 1934, pt. 2, pp. 468-473, Nat. Research Council, June 1934.

Fortier, Samuel, and Blaney, H. F., Silt in the Colorado River and its relation to irrigation: U. S. Dept. Agr., Tech. Bull. 67, 1928.

Gilbert, G. K., The transportation of debris by running water: U. S. Geol. Survey Prof. Paper 86, 1914.

Gilbert, G. K., Hydraulic-mining debris in the Sierra Nevada: U. S. Geol. Survey Prof. Paper 105, 1917.

Howard, C. S., Suspended matter in the Colorado River in 1925-1928: U. S. Geol. Survey Water-Supply Paper 636, pp. 15-44, 1930.

- Lane, E. W., and Kalinske, A. A., The relation of suspended to bed material in rivers: Am. Geophys. Union Trans., 20th Ann. Meeting, pt. 4, pp. 637-641, Nat. Research Council, 1939. 
Leighly, John, Toward a theory of the morphologic significance of turbulence in the flow of water in streams: Univ. of Calif. Pubs. in Geography, vol. 6 pp. 1-22, 1932.

Leighly, John, Turbulence and the transportation of rock debris by streams: Geog. Rev., vol. 24, pp. 453-464, 1934.

O'Brien, M. P., Review of the theory of turbulent flow and its relation to sediment transportation: Am. Geophys. Union Trans., 14th Ann. Meeting, 1933, pp. 487-491, Nat. Research Council, 1933.

O'Brien, M. P., and Rindlaub, B. D., The transportation of bed load by streams:: Am. Geophys. Union Trans., 14th Ann. Meeting, 1934, pt. 2, pp. 593-603, Nat. Research Council, 1934.

O'Brien, M. P., Notes on the transportation of silt by streams: Am. Geophys. Union Trans., 17th Ann. Meeting, 1936, pt. 2, pp. 431-438, Nat. Research Council, 1936.

Rubey, W. W., Equilibrium conditions in debris-laden streams: Am. Geophys. Union Trans., 14th Ann. Meeting, 1933, pp. 497-505, Nat. Research Council, 1933.

Rubey, W. W., The force required to move particles on a stream bed: U. S. Geol. Survey Prof. Paper 189-E, pp. 121-142, 1938.

Troxell, H. C., and Peterson, J. Q., Flood in La Cañada Valley, Calif., January 1, 1934: U. S. Geol. Survey Water-Supply Paper 796-C, pp. 69-93, 1937.

U. S. Bur. Reclamation, Bibliography on the subject of transportation of solids by flowing water in open channels, Denver, Colo., 1983.

Williams, G. R., and others, Selected bibliography on erosion and silt movement: U. S. Geol. Survey Water-Supply Paper 797, 1937. (Concerns works in foreign languages only.)

\section{RIVER FLOOD-PLAIN AND DELTA SEDIMENTATION AND ASSOCIATED SEDIMENTARY STRUCTURES}

Bell, H. S., Armored mud balls-their origin, properties, and role in sedimentation: Jour. Geology, vol. 48, pp. 1-31, 1940.

Bradley, W. H., Factors that determine the curvature of mud-cracked layers: Am. Jour. Sci., 5th ser., vol. 26, pp. 55-71, 1933.

Chawner, W. D., Aluvial fan flooding; the Montrose, Calif., flood of 1984: Geog. Rev., vol. 25, pp. 255-263, 1935.

Cotton, C. A., Classification and correlation of river terraces: Jour. Geomorphology, vol. 3, pp. 27-37, 1940.

Eckis, Rollin, Alluvial fans of the Cucamonga district, southern. California: Jour. Geology, vol. 36, pp. 224-247, 1928.

Evans, O. F., Some observations on erosion and transportation in the Wichita Mountains area: Oklahoma Acad. Sci. Proc., vol. 2 (Oklahoma Univ. Bull., new ser., no. 247), pp. 77-79, 1922.

Fenneman, N. M., Flood plains produced without floods: Amer. Geog. Soc. Bull., vol. 38, pp. 89-91, 1906.

Fox, C. K., The Colorado delta: a discussion of the Spanish explorations and maps, the Colorado River silt load, and its seismic effect on the Southwest, Los Angeles, 1936.

Gilbert, G. K., Ripple marks and cross-bedding: Geol. Soc. America Bull., vol. 10, pp. 135-140, 1899.

Johnston, W. A., Sedimentation of the Fraser River delta: Canada Geol. Survey Mem. 125, 1921. 
Johnston, W. A., The character of the stratification of the sediments in the Recent delta of the Fraser River, British Columbia, Canada: Jour. Geology, vol. 30, pp. 115-129, 1922.

Kindle, E. M., Some factors affecting the development of mud cracks: Jour. Geology, vol. 25, pp. 135-144, 1917.

Lugn, A. L., Sedimentation on the Mississippi River between Davenport, Iowa, and Cairo, I1l.: - Angustana Library Pub. 11, 1927.

Lugn, A. L., An observed origin of some mud pebbles: Iowa Acad. Sci. Proc., 1927, vol. 34, pp. 249-251, 1928.

McKee, E. D., Some types of bedding in the Colorado River delta: Jour. Geology, vol. 47 , pp. $64-81,1939$.

McKee, E. D., Original structures in Colorado River flood deposits of Grand Canyon: Jour. Sedimentary Petrology, vol. 8, pp. 77-83, 1938.

Melton, F. A., An empirical classification of flood-plain streams: Geog. Rev., vol. 26 , pp. $593-609,1936$.

Nevin, C. M., and Trainer, D. W., Jr., Laboratory study in delta building: Geol. Soc. America Bull., vol. 38, pp. 451-458, 1927.

St. Clair, David, Correlation of river terrace remnants: Science, new ser., vol. 86 , pp. 399-400, 1937

Sykes, Godfrey, Study of the delta of the Colorado River: Carnegie Inst. Washington Year Book 29, pp. 411-413, 1930.

Sykes, Godfrey, The Colorado delta! Carnegie Inst. Washington Pub. 460, 1937.

Trowbridge, A. C., The building of the Mississippi delta: Am. Assoc. Petroleum Geologists Bull., vol. 14, pp. 867-901, 1930.

Upham, Warren, Recognition of river and flood-plain deposits : Am. Geologist, vol. 25 , pp. 313-314, 1900 .

Wright, F. J., The physiography of the Upper James River Basin in Virginia: Virginia Geol. Survey Bull. 11, pp. 35-41, 1925.

\section{LAKE AND RESERVOIR SILTING}

Barnes, F. F., Kraebel, C. J., and La Motte, R. S., Effect of accelerated erosion on silting in Morena Reservoir, San Diego Countv, Calif.: U. S. Dept. Agr. Tech. Bull. 639, pp. 11-20, 1939.

Eakin, H. M., Silting of reservoirs: U. S. Dept. Agr. Tech. Bull. 524, 1936.

Fiock, L. R., Records of silt carried by the Ria Grande and its accumulation in Elephant Butte Reservoir: Am. Geophys. Union Trans., 15th Ann. Meeting, 1934, pt. 2, pp. 468-173, Nat. Research Council, June 1934.

Grover, N. C., and Howard, C. S., The passage of turbid water through Lake Mead: Am. Soc. Civil Eng. Proc., vol. 63, pp. 643-655, 1937.

Hough, J. L., Underflow in Lake Lee, N. C.: Civil Eng., vol. 9, pp. 36-37, 1939.

Stevens, J. C., The silt problem: Am. Soc. Civil Eng. Proc., vol. 62, pt. 2, pp. 207-288, 1936.

U. S. Soil Conservation Service, Advance reports on sedimentation surveys of lakes and reservoirs, as follows:

SS 1, Kesler, T. L., Lake Spavinaw, Spavinaw, Okla., 1936.

SS 2, Dobson, G. C., and Brown, C. B., Instructions for reservoir sedimentation surveys, 1936.

SS 3, Glymph, L. M., Jr., and Jones, V. H., Lake Booneville, Ark., 1936. 
SS 4, Eargle, D H., Lake Harris, Tuscaloosa, Ala., 1936.

SS 5, Eargle, D. H., Lake Purdy, Birmingham, Ala., 1936.

SS 6, Brown, C. B., and Barnes, F. F., New River, Va. and W. Va., 1936.

SS 7, Glymph, L. M., Jr., and Jones, V. H., Lake Sapulpa, Sapulpa, Okla., 1936.

SS 8, Kesler, T. L., Lake Taneycomo, Taney County, Mo., 1936.

SS 9, Glymph, L. M., Jr., and Jones, V. H., Lake Bennett, Conway, Ark., 1936.

SS 10, Eargle, D. H., High Rock Reservoir, Salisbury, N. C., 1937.

SS 11, Eargle, D. H., and Barnes, F. F., Bayview Reservoir, Birmingham, Ala., 1937.

SS 12, Glymph, L. M., Jr., and Jones, V. H., Lake Decatur, Decatur, Ill, 1937.

SS 13, Barnes, F. F., Lay Resetvoir, Clanton, Ala., 1937.

SS 14, Jones, V. H., Lake Bracken, Galesburg, Ill., 1937.

SS 15, Jones, V. H., West Frankfort Reservoir, West Frankfort, III., 1937.

SS 16, Glymph, L. M., Jr., and Jones, V. H., Lake Calhoun, Galva, Ill., 1937.

SS 17, Glymph, L. M., Jr., and Jones, V. H., Lakes Crook and Gibbons, Paris, Tex., 1937.

SS 18, Flaxman, E. M., and Barnes, L. H., Ottawa County State Lake, Bermington, Kans., 1937.

SS 19, Hough, J. L., and Flaxman, E. M., Black Canyon Reservoir, Emmett, Idaho, 1937.

SS 20, Connaughton, M. P., Hayes Lake, Hayes, S. Dak., 1938.

SS 21, Jones, V. H., Baker Reservoir, Baker, Mont., 1938.

SS 22, Jones, V. 'H., Mission Lake, Horton, Kans., 1938.

SS 23, Jones, V. H., Wellfleet Reservoir, Wellfleet, Nebr., 1938.

SS 24, Jones, V. H., Lake Olathe, Olathe, Kans., 1938.

SS 25, Jones, V. H., Lake Eldorado, Eldorado, Kans., 1938.

SS 26, Glymph, L. M., Jr., Hurley Lake, Gettysburg, S. Dak., 1938.

SS 27, Hough, J. L., and Flaxman, E. M., Bennett Irrigation and Silting Basin, Wilson Creek, .Wash., 1938.

SS 28, Connaughton, M. P., and Hough, J. L., Burlington Reservoir, Burlington, N. C., 1938.

SS 29, Barnes, F. F., Barcroft Reservoir, Alexandria, Va., 1939.

SS 30, Connaughton, M. P., and Barnes, L. H., Franklinton Reservoir, Franklinton, N. C., 1939.

SS 31, Barnes, F. F., and Brown, C. B., Burnt Mills Reservoir, Silver Spring, Md., 1939.

SS 32, Brown, C. B., Seaoy, L. M., and Rittenhouse, Gordon, York River, Va., 1939.

SS 33, Barnes, F. F., and Brown, C. B., Greenbelt Lake, Greenbelt, Md., 1939.

SS 34, Connaughton, M. P., and Hough, J. L., Lake Lee, Monroe, N. C., 1939. 


\section{FREQUENCY AND FORECASTING OF FLOODS}

Bernard, Merrill, Hydrologic aspects of flood forecasting: Am. Geophys. Union Trans., Regional Meeting, 1937, pp. 518-520, Nat. Research Council, 1937.

Bernard, Merrill, Recent developments in flood forecasting: Am. Geophys. Union Trans., 20th Ann. Meeting, 1939, pt. 2, pp. 187-193, Nat. Research Council, 1939.

Clyde, G. D., Stream-flow forecasting by snow-surveying: Civil Eng., vol. 9, pp. 237-239, 1939.

Creager, W. P., Possible and probable future floods: Civil Eng., vol. 9, pp. 668$670,1939$.

Grant, E. L., The probability viewpoint in hydrology: manuscript of paper presented before Am. Geophys. Union, Sec. of Hydrology, Stanford meeting, Jan. $12,1940$.

Hazen, A. D., Flood flows, a study of frequencies and magnitudes, New York, John Wiley and Sons, Inc., 1930.

Hinds, N. E. A., Geological evidences of Recent floods: Am. Geophys. Union Trans., 19th Ann. Meeting, 1938, pt. 2, pp. 646-647, Nat. Research Council, 1938.

Jarvis, C. S., Great floods in the United States: Am. Geophys. Union Trans., 20th Ann. Meeting, 1939, pt. 2, pp. 157-166, Nat. Research Council, 1939.

Matthes, G. H., Flood data in the United States: Am. Geophys. Union Trans., 20th Ann. Meeting, 1939, pt. 2, pp. 155-157, Nat. Research Council, 1939.

O'Connell, R. P. L., The flood discharge of rivers: Inst. Civil Eng., vol. 27, pp. 207-217, 1868.

Sherman, L. K., Recent advances in applied hydrology with reference to flood forecasting: Am. Geophys. Union Trans., 20th Ann. Meeting, 1939, pt. 2, pp. 174-176, Nat. Research Council, 1939.

White, G. F., Economic aspects of flood forecasting: Am. Geophys. Union Trans., 20th Ann. Meeting, 1939, pt. 2, pp. 218-233, Nat. Research Council, 1939.

\section{SELECTED BIBLIOGRAPHIES ON FLOOD METEOROLOGY, HYDROLOGY, AND SEDIMENTATION}

Am. Geophys. Union, Bibliography of Hydrology, United States of America, Years 1935 and 1936, 78 pp., Nat. Research Council, 1937.

Am. Geophys. Union, Bibliography of Hydrology, United States of America, Year 1937, 68 pp., Nat. Research Council, 1938.

Am. Geophys. Union, Bibliography of Hydrology, United States of America, Year 1938, 72 pp., Nat. Research Council, 1939.

Church, J. E., and others, List of current publications to accompany Report of the Committee on Snow: Am. Geophys. Union Trans., 16th Ann. Meeting, 1935, pt. 2, pp. 382-383, Nat. Research Council, 1935.

Church, J. E., and others, List of current publications to accompany Report of the Committee on Snow: Am. Geophys. Union Trans., 17th Ann. Meeting, 1936, pt. 2, pp. 281-282, Nat. Research Council, 1936.

Church, J. E., and others, List of current publications to accompany Repart of the Committee on Snow: Am. Geophys. Union Trans., 18th Ann. Meeting, 1937, pt. 2, pp. 282-284, Nat. Research Council, 1937.

Elges, Carl, and Stone, R. G., List of current publications to accompany Report of the Committee on Snow: Am. Geophys. Union Trans., 19th Ann. Meeting, 1938, pt. 1, pp. 301-305, Nat. Research Council, 1938. 
Elges, Carl, List of current publications to accompany Report of the Committee on Snow: Am. Geophys. Union Trans., 20th Ann. Meeting, pt. 4, pp. 621-622, Nat. Research Council, 1939.

Hoyt, W. G., and others, Studies of relations of rainfall and runoff in the United States: U. S. Geol. Survey Water-Supply Paper 772, pp. 283-294, 1936.

Jarvis, C. S., and others, Floods in the United States, magnitude and frequency: U. S. Geol. Survey Water-Supply Paper, 771, pp. 468-487, 1936.

Marvis, F. T., and others, Bibliographical abstracts to accompany Report of the Subcommittee on Bibliography: Am. Geophys. Union Trans., 20th Ann. Meeting, pt. 4, pp. 581-606, Nat. Research Council, 1939.

Straub, L. G., Bibliography to accompany Report of Committee on Dynamics of Streams: Am. Geophys. Union Trans., 16th Ann. Meeting, 1985, pt. 2, pp. 447451, Nat. Research Council, 1935.

Straub, L. G., Bibliography to accompany Report of Committee on Dynamics of Streams: Am. Geophys. Union Trans., 18th Ann. Meeting, 1937, pt. 2, pp. 333342, Nat. Research Council, 1937.

Straub, L. G., Bibliography to accompany Report of Committee on Dynamics of Streams: Am. Geophys. Union Trans., 20th Ann. Meeting, pt. 4, pp. 557-579, Nat. Research Council, 1939.

Straub, L. G., Bibliography to accompany Report of Committee on Dynamics of Streams: Am. Geophys. Union Trans., 21st Ann. Meeting, pt. 2, pp. 447-450, Nat. Research Council, 1940.

Wieland, L. H., Soil-erosion bibliography, Washington, U. S. Dept. Interior, Soil Erosion Serv., 1935.

\section{MISCELLANEOUS}

Many papers dealing directly or indirectly with flood problems have appeared in the Transactions of the American Geophysical Union. The more important of these are cited individually in the foregoing lists; others are included in some of the bibliographies to which reference has been made. For these reasons, individual citations are not included in the following list: instead, those parts of the Transactions which contain the pertinent papers are indicated.

Am. Geophys. Union Trans., 15th Ann. Meeting, 1934, pt. 2, Section of Hydrology, pp. 419-432, 444-454, 468-515, 593-611, Nat. Research Council, 1934.

Am. Geophys, Union Trans., 16th Ann. Meeting, 1935, pt. 2, Section of Hydrology, pp. 456-485, 492-495, Nat. Research Council, 1935.

Am. Geophys. Union Trans., Pacific Coast Meeting, 1936, Section of Hydrology, pp. 526-528, 1936.

Am. Geophys. Union Trans., 17th Ann. Meeting, 1936, pt. 2, Section of Hydrology, pp. 406-415, 431-452, Nat. Research Council, 1936.

Am. Geophys. Union Trans., 18th Ann. Meeting, 1937, pt. 2, Section of Hydrology, pp. 409-432, 439-484, Nat. Reseárch Council, 1937.

Am. Geophys. Union Trans., Regional Meeting, 1937, Section of Hydrology, pp. 518-520, 541-551, 554-557, 592-600, Nat. Research Council, 1937.

Am. Geophys: Union Trans., 19th Ann. Meeting, 1938, pt. 1, Section of Hydrology, pp. 455-486, 501-517, Nat. Research Council, 1938.

Am. Geophys. Union Trans., 19th Ann. Meeting, 1938, pt. 2, Section of Hydrology, pp. 595-607, 619-662, Nat. Research Council, 1938.

Am. Geophys. Union Trans., 20th Ann. Meeting, 1939, pt. 4, Section of Hydrology, pp. 637-656, 693-711, 725-738, Nat. Research Council, 1939.

Am. Geophys. Union Trans., 21st Ann. Meeting, 1940, pt. 2, Section of Hydrology, pp. 485-499, 596-633, 649-668, Nat. Research Council, 1940. 



\section{INDEX}

\begin{tabular}{|c|c|}
\hline Page & Page \\
\hline 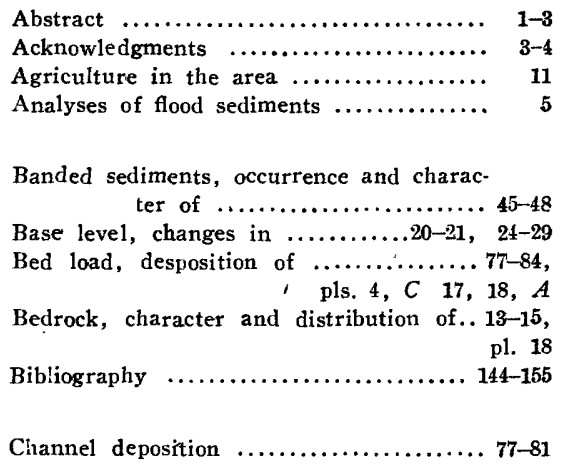 & 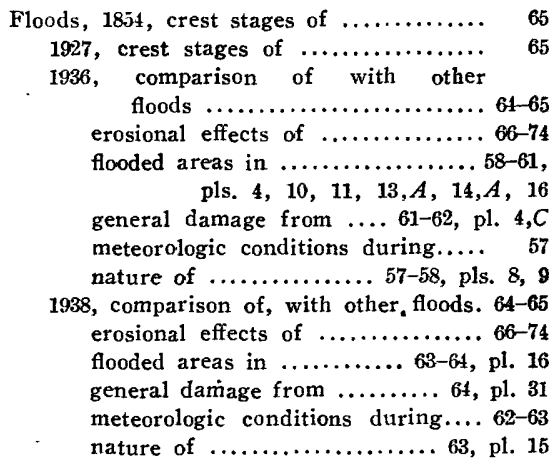 \\
\hline
\end{tabular}

Channel erosion caused by floods $67-68,73-74$

Chicopee River, terraces along ..........

Climate of the area $. . . \ldots \ldots \ldots \ldots \ldots \ldots . . .10$

Connecticut River, channel characteristics

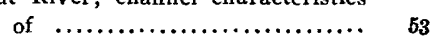

channel scour of $\ldots \ldots \ldots \ldots \ldots \ldots \ldots \ldots$ 73-74

comparison of other rivers with $\ldots \ldots .51-54$,

pl. 7

flood-inundation cycle of $\ldots \ldots \ldots .54-57$, pl.8 gage-height curves for, Sept. 1, 1938.. 63,

pl. 15

lateral channel control along ......... 53-54

postglacial course of $\ldots \ldots \ldots \ldots \ldots \ldots \ldots$ 29-34

principal tributaries of $\ldots . \ldots \ldots \ldots \ldots .54$

slumping of banks of $\ldots \ldots \ldots \ldots \ldots \ldots, 71-72$

terraces and flood plains of $\ldots \ldots \ldots \ldots .34-50$

Connecticut River Valley, geography of... 6-13 geology of $\ldots \ldots \ldots \ldots \ldots \ldots \ldots \ldots \ldots, 13-17$ gully erosion in $\ldots \ldots \ldots \ldots \ldots \ldots 66-67,68-69$ physiographic development of ....... 17-29

Control of future floods, recommendations

for $\ldots \ldots \ldots \ldots 133-136$, pls. $31,32,53$

Crustal movements $\ldots \ldots \ldots .20-21,26-29,42-43$

Debris ffans, formation of $\ldots \ldots \ldots \ldots \ldots .81-82$, pls. $17, B, 18$

Deerfiefild Meadows, features of ......... 41

Deltas, formation of $\ldots \ldots \ldots . .82-84$, pl. 33, $A$

Discharge curves for Connecticut River, March 1936 .......... 57-58, pl. 9

Erosional effects of floods of 1986 and $1938 \ldots \ldots \ldots \ldots \ldots \ldots \ldots . . .66-74$

Gage-height curves for Connecticut River,

September $1938 \ldots \ldots \ldots \ldots 63$, p1. 15

Gullying caused by floods ...... 66-67, 68-69

Hadley-Hatfield Meadows, features of

Connecticut River through .. 32,

40,44, pls. 4,6

Holyoke Narrows, features of ......... 32-33

Hurricane flood of September 1938 .... 62-64

Laboratory work $\ldots \ldots \ldots \ldots \ldots \ldots \ldots \ldots \ldots$ 5

Lily Pond terrace, features of $\ldots \ldots \ldots 35-36,40$,

pl. $4, C$

Location and extent of the area ........ 6, 7

Loess, occurrence and character of .... 48-49

Meanders, cutting off of $\ldots \ldots \ldots \ldots \ldots \ldots, 72$

development of $\ldots \ldots \ldots \ldots \ldots \ldots \ldots \ldots, 43-44$

Montague Meadows, features of $\ldots \ldots \ldots \ldots$ 31-32

Northfield Meadows, features of $\ldots, \ldots .30,40$

Oxbows, development of $\ldots \ldots \ldots \ldots \ldots \ldots .44$

Periodicity, of floods, evidence of low

river-terrace sections for .... 129-130

evidence of previous deposits for ... 128-129

historic records of $\ldots \ldots \ldots \ldots \ldots, 127, \mathrm{pl} .29$

meteorologic factors for ......... 130-132,

pls. $28,29,30$

probability studies of $\ldots \ldots \ldots \ldots \ldots \ldots, 127-128$ problem of $\ldots \ldots \ldots \ldots \ldots \ldots \ldots \ldots \ldots \ldots .126-127$

Filed work in the area

Flood-inundation cycle

Flood plains. See Terrace and flood-plain deposits.

Flood sedimentation, features of ........ 74-126

Flood sediments, transportation of

Pleistocene period, crustal subsidence dur-

ing $\ldots \ldots \ldots \ldots \ldots \ldots \ldots \ldots \ldots, 20-21$

formation of terraces during ......... 21-23

work of the ice sheets during ....... 19-20

Population, distribution of $\ldots \ldots \ldots \ldots \ldots 11-12$ 




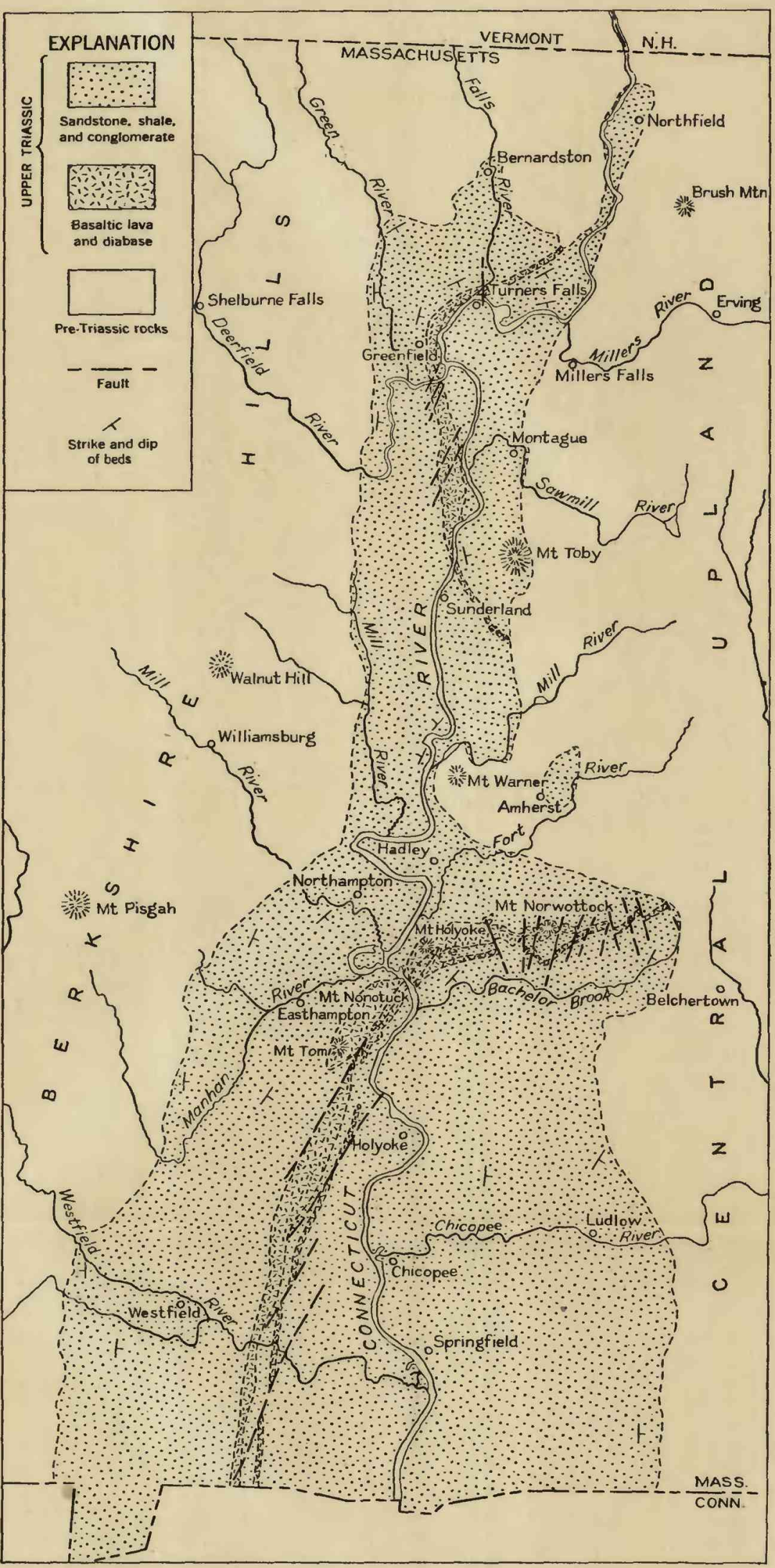

10 Miles 


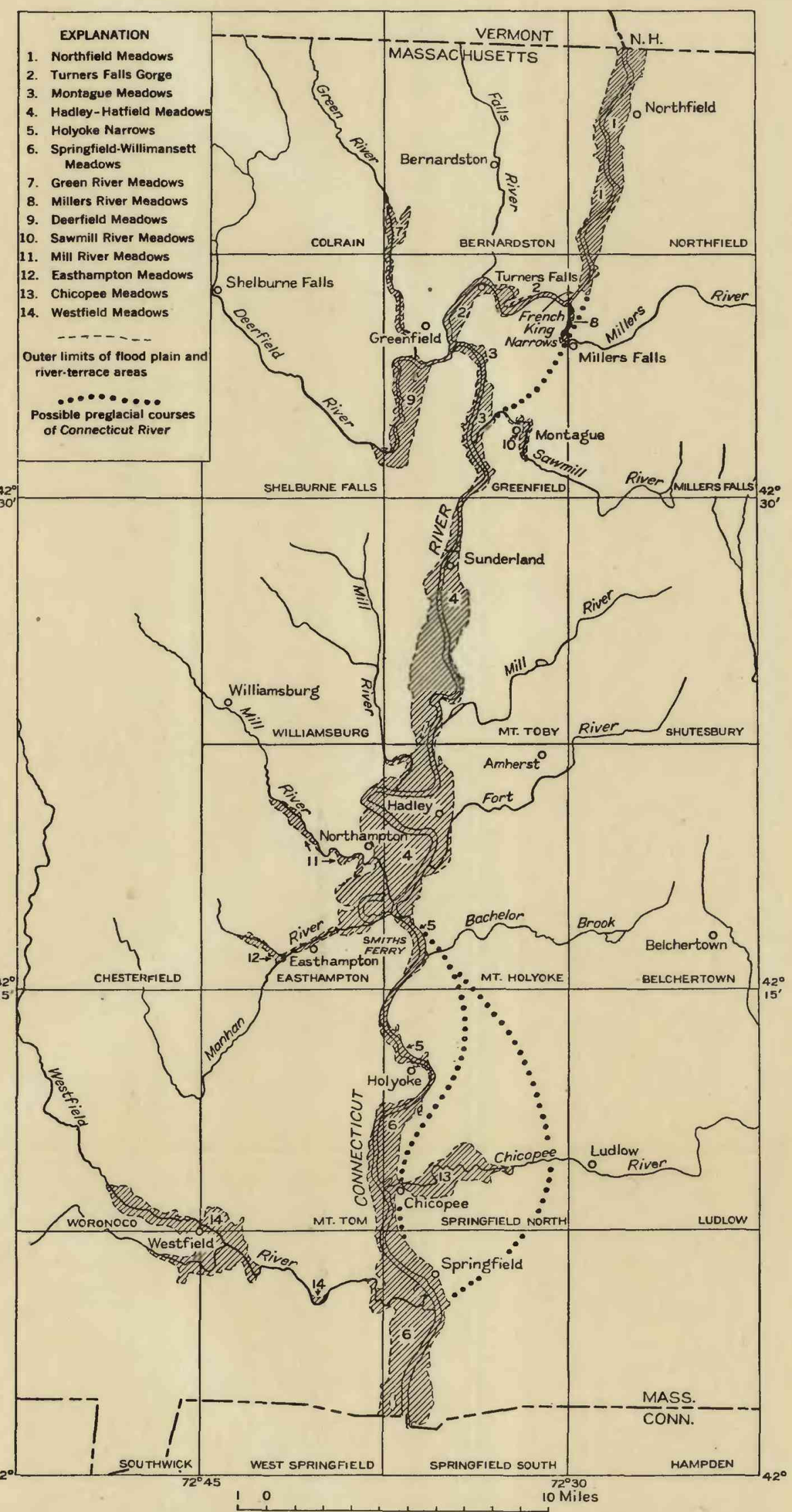

QUADRANGLE INDEX MAP OF CENTRAL-WESTERN MASSACHUSETTS, SHOWING PHYSIOGRAPHIC DIVISIONS OF THE PRINCIPAL FLOODPLAIN AND RIVER-TERRACE AREAS. 


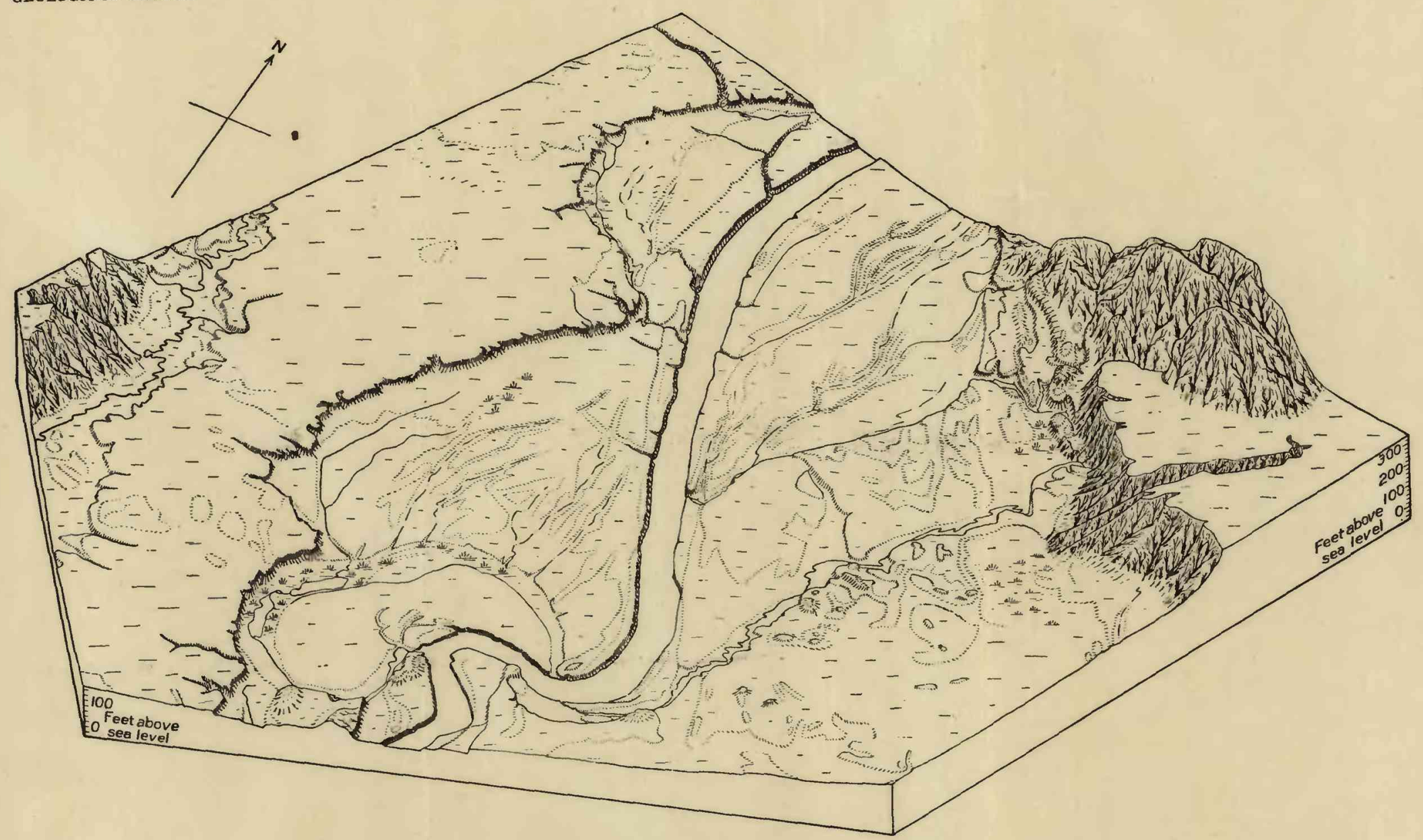

A. Generalized block diogrom, including river-terrace and flood plain oreas

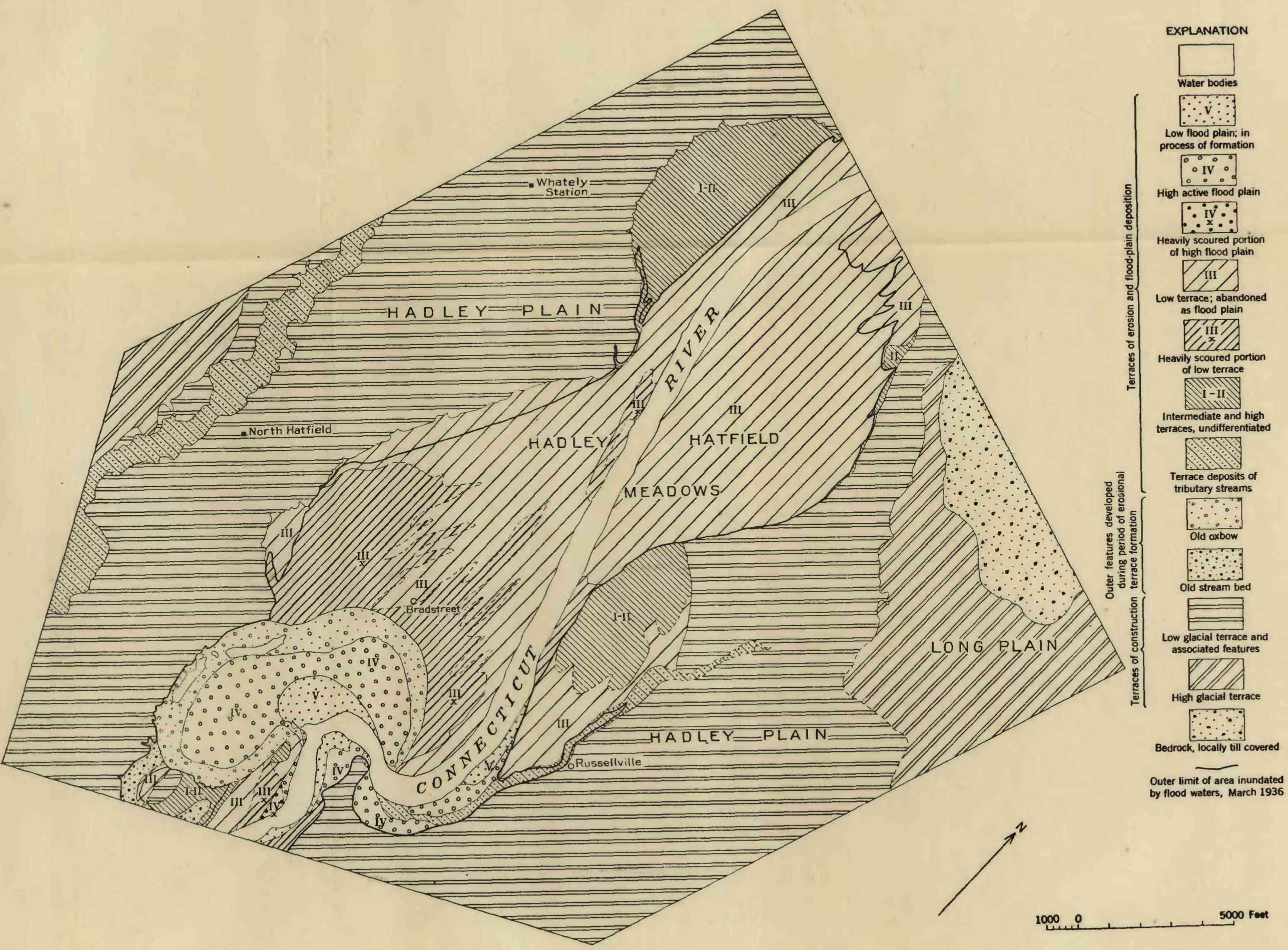

8. Generalized map of Quaternary land farms in the area of the abave black

AXIAL PART OF THE CONNECTICUT VALLEY NORTH OF MOUNT WARNER AND SOUTHWEST OF MOUNT TOBY. 


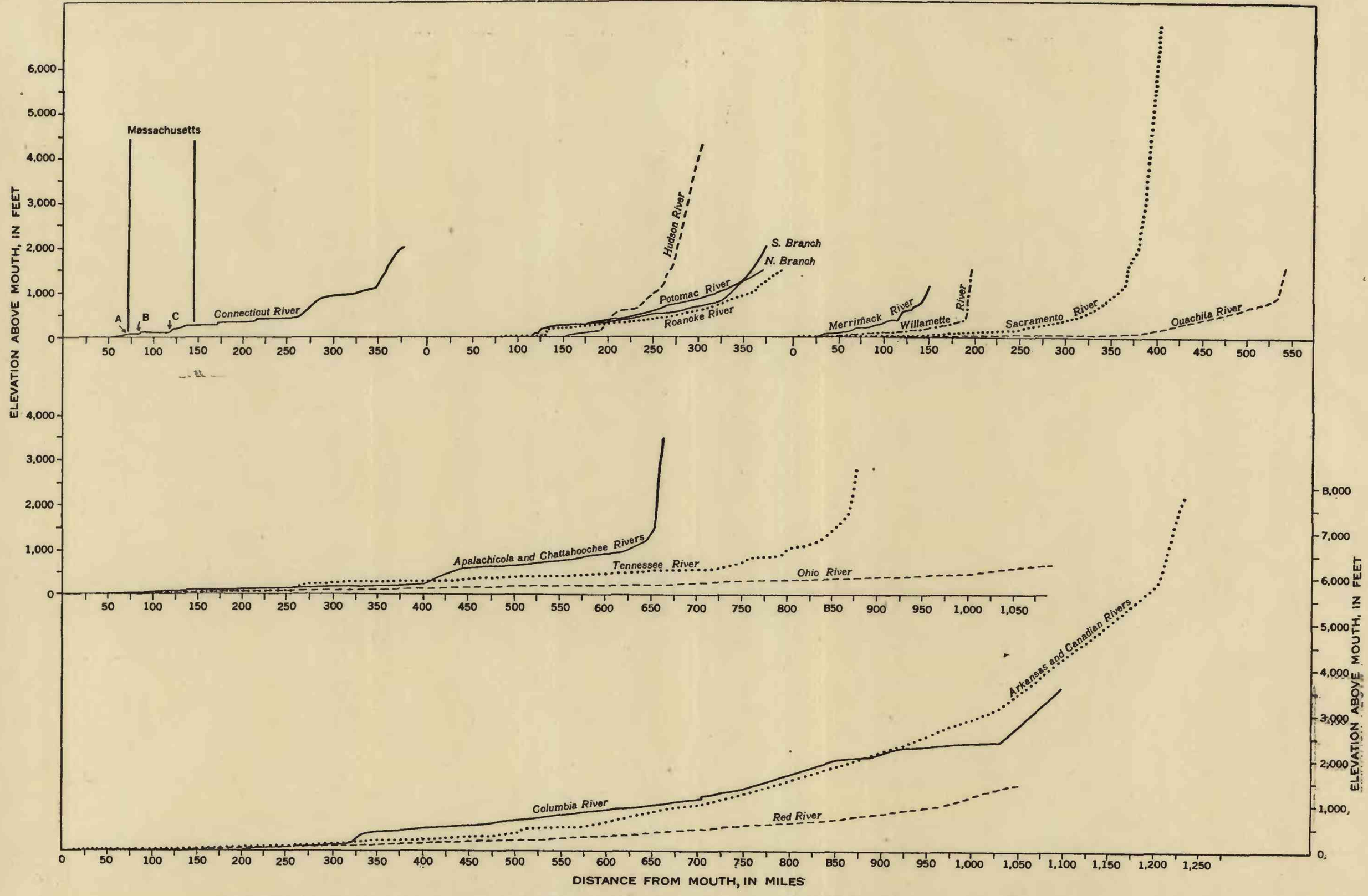

PROFILES OF THE CONNECTIGUT RIVER AND OTHER IMPORTANT RIVERS IN THE UNITED STATES. 


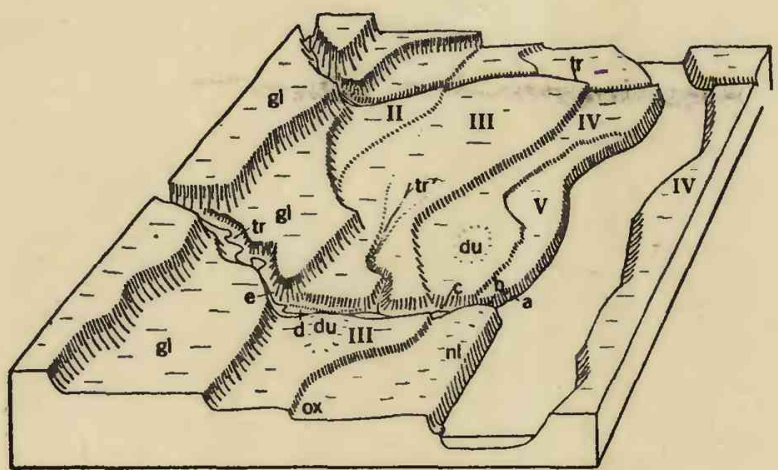

A. NORMAL: LOW-WATER CONDITION

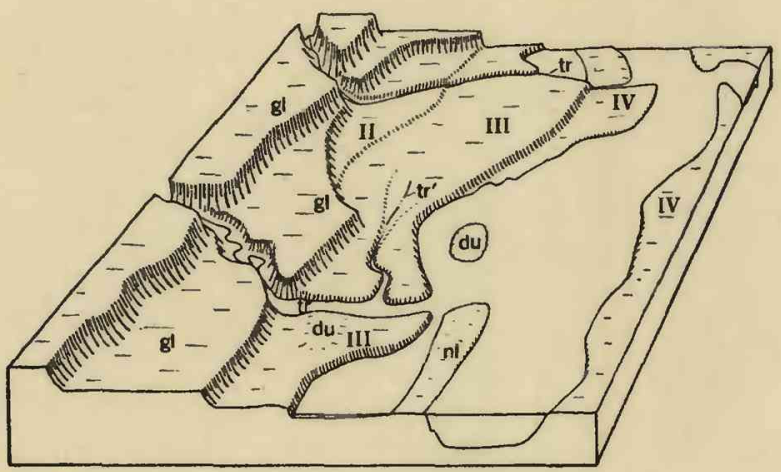

C. FLOOD: RISING CONDITION

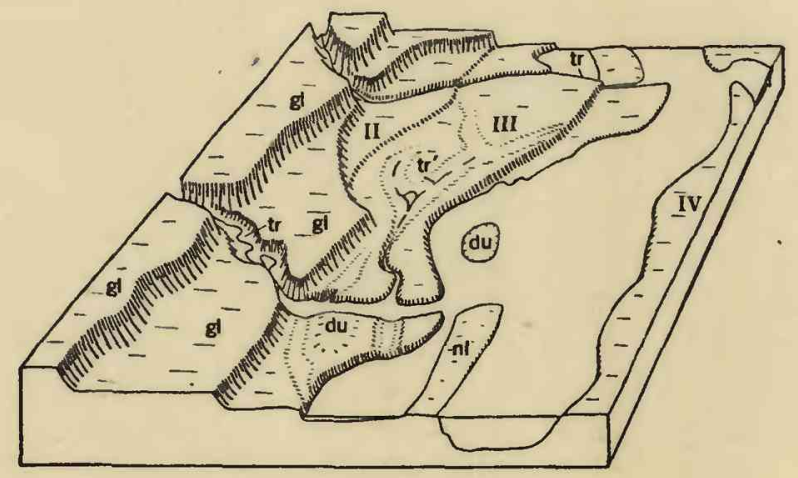

E. FLOOD: FALLING CONOITION

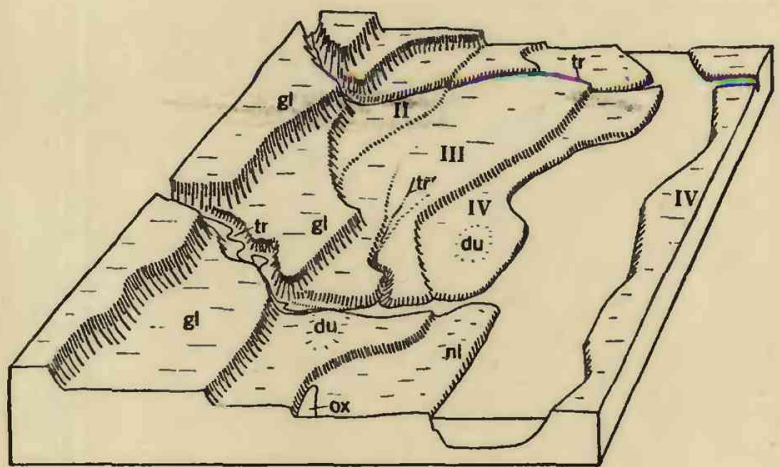

B. NORMAL: HIGH-WATER CONDITION

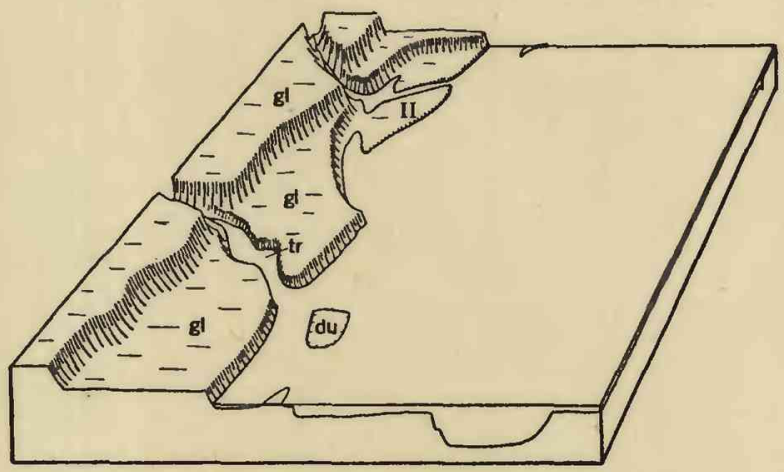

D. FLOOD: PEAK CONGITION

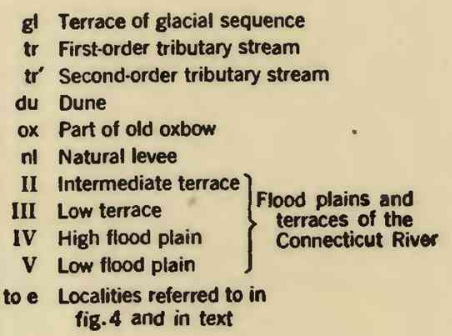

IV High flood plain $\quad$ Connecticut River

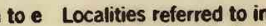
fig. 4 and in text

BLOCK DIAGRAMS OF AN IDEALIZED AREA ALONG THE CONNECTICUT RIVER, SHOWING RELATIONS OF CERTAIN RIVER STAGES TO LAND FORMS. 


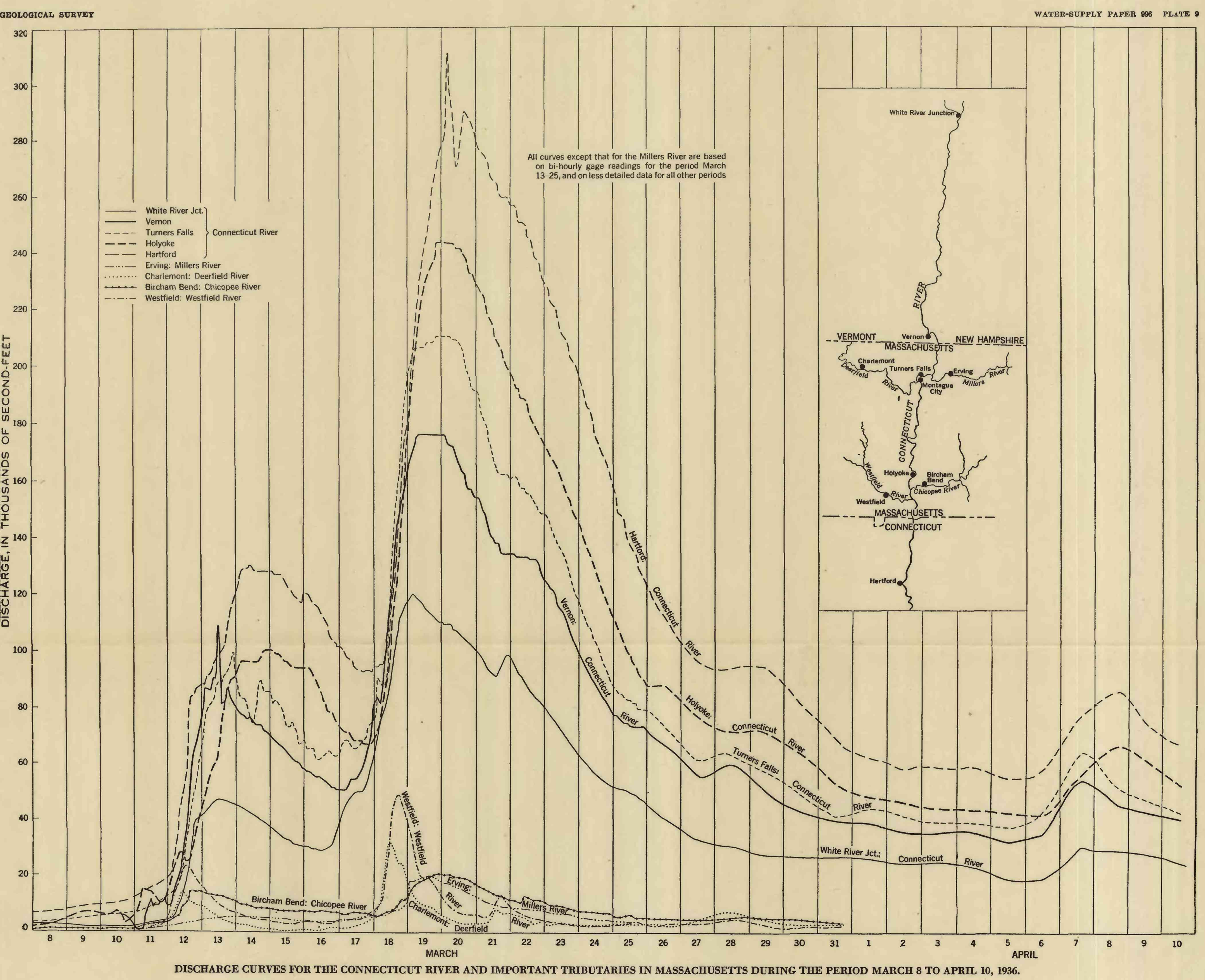




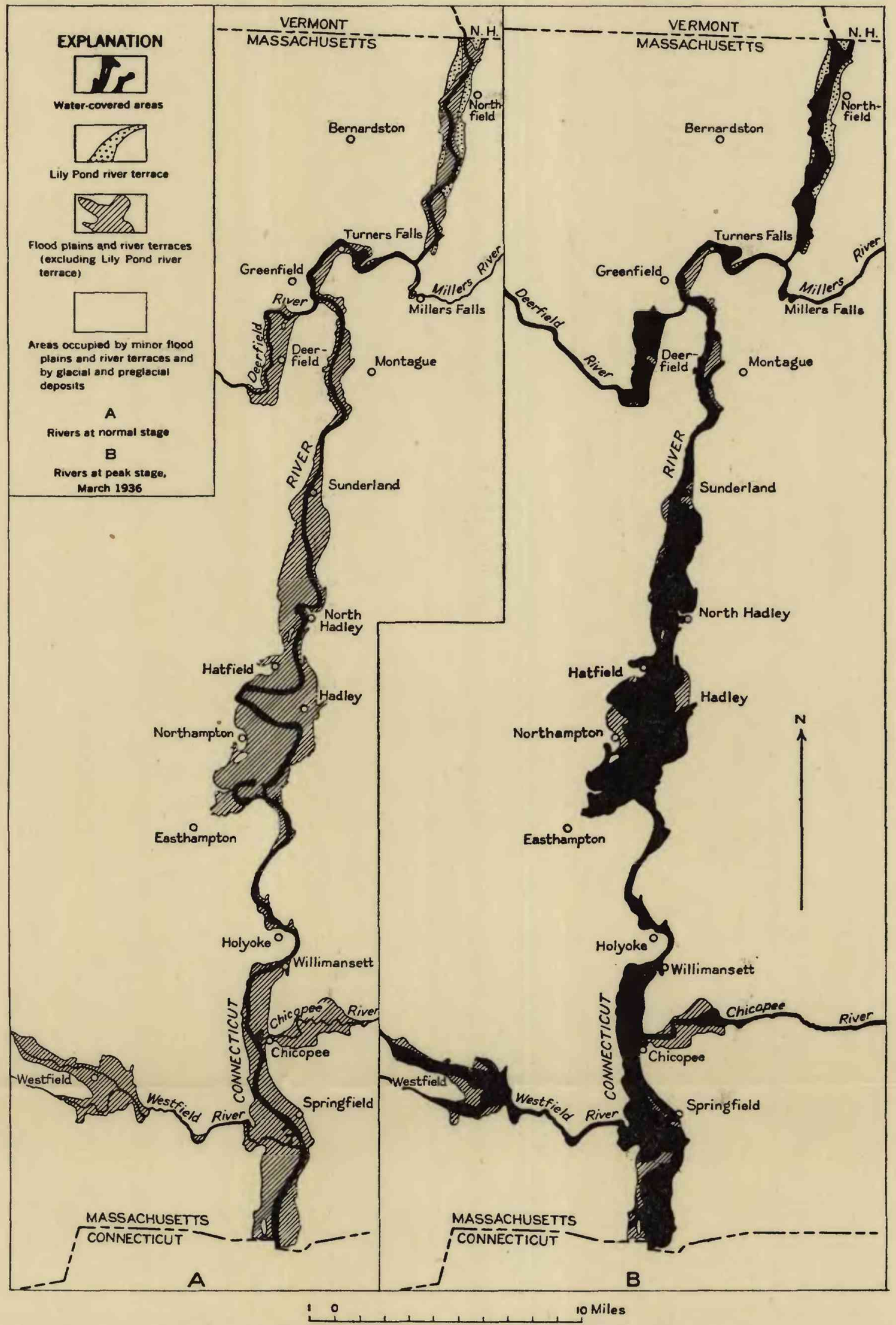




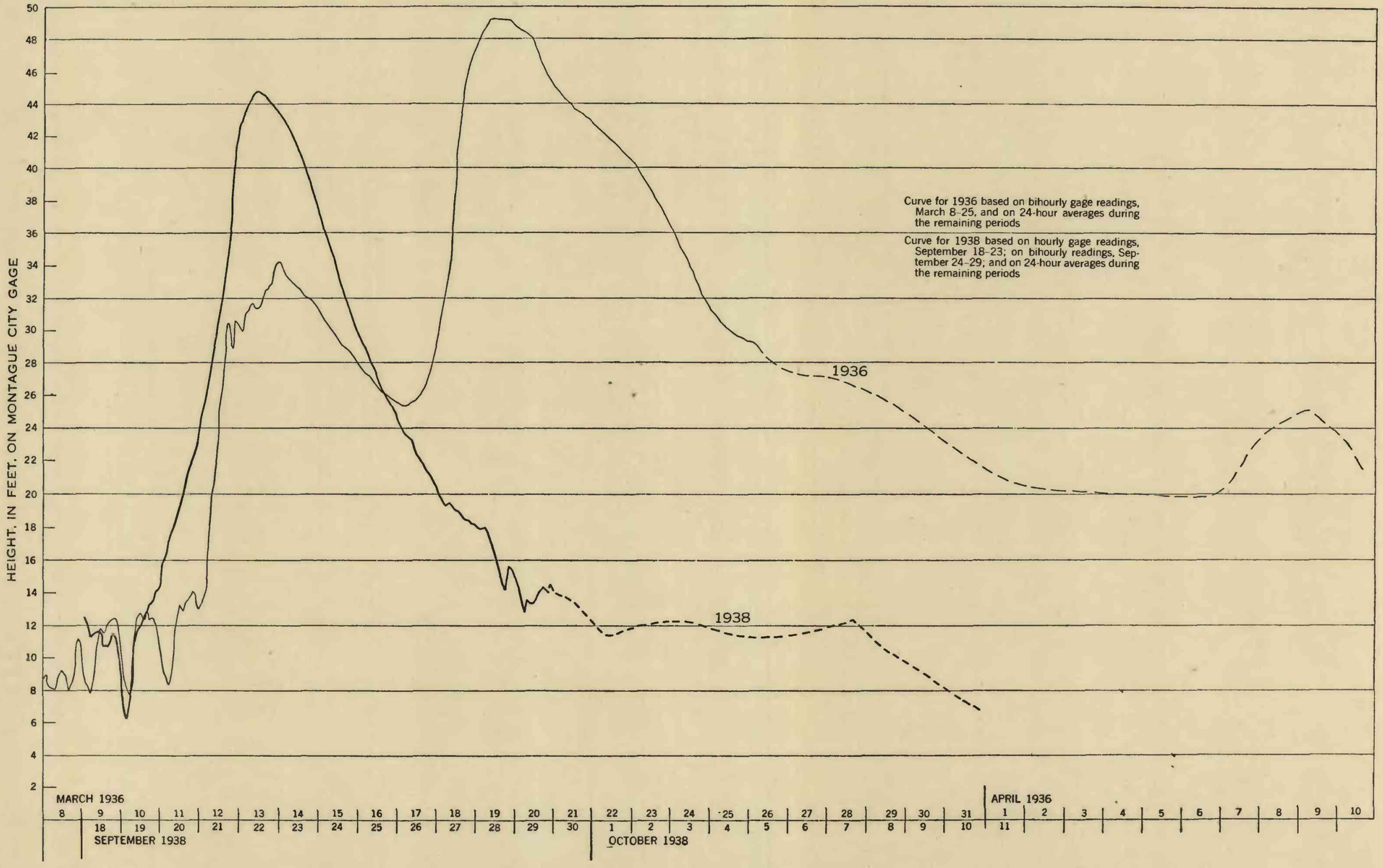

GAGE-IIEIGHT CURVES FOR THE CONNECTICUT RIVER AT MONTAGUE, MASS., MARCH 8 TO APRIL 10, 1936, AND SEPTEMBER 18 TO OCTOBER 11, 1938. 


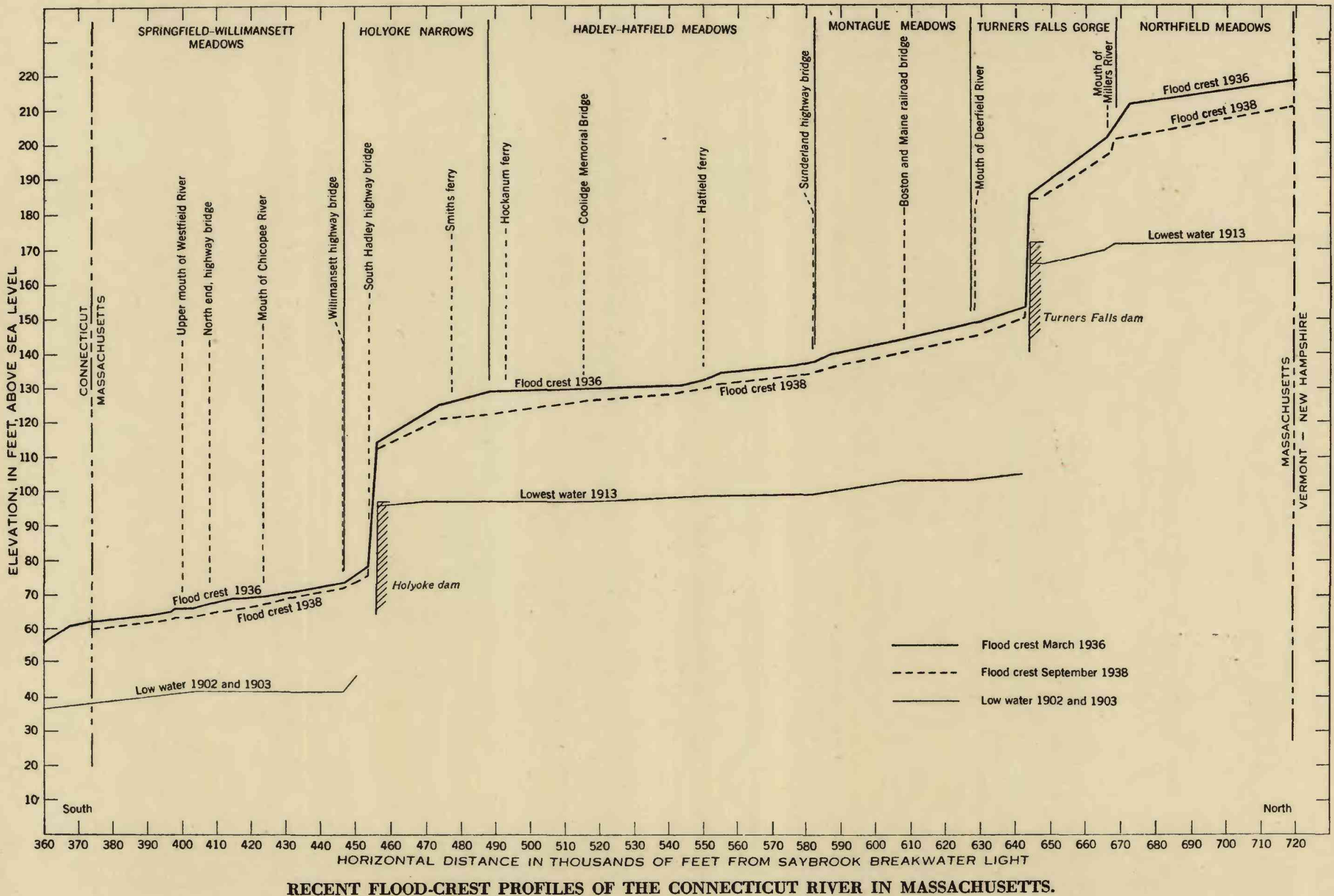




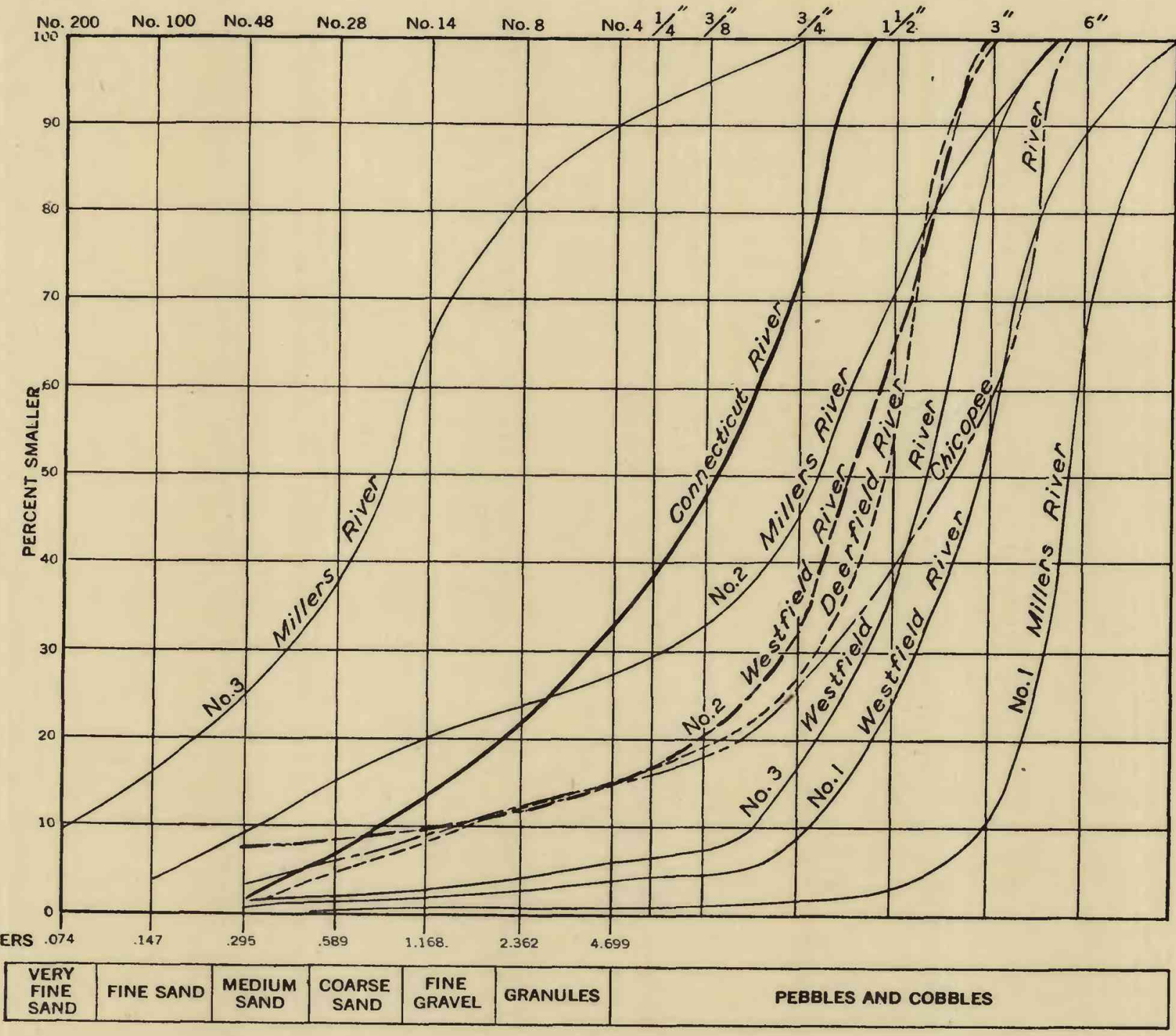

A. Sieve analyses for Connecticut, Westfield, Millers, and Deerfield Rivers

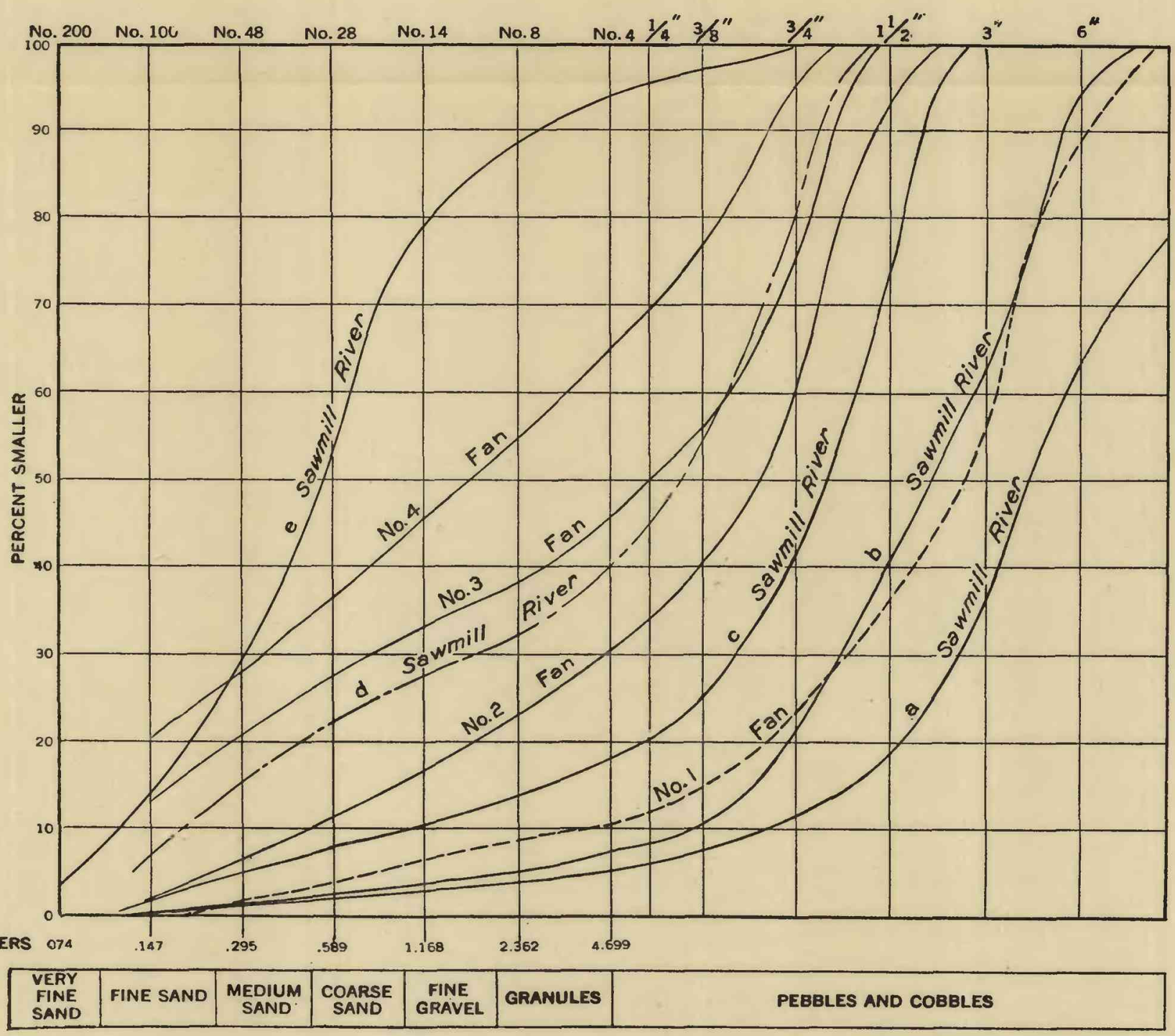

B. Sieve analyses for Sawmill River and for small debris fan west of Montague

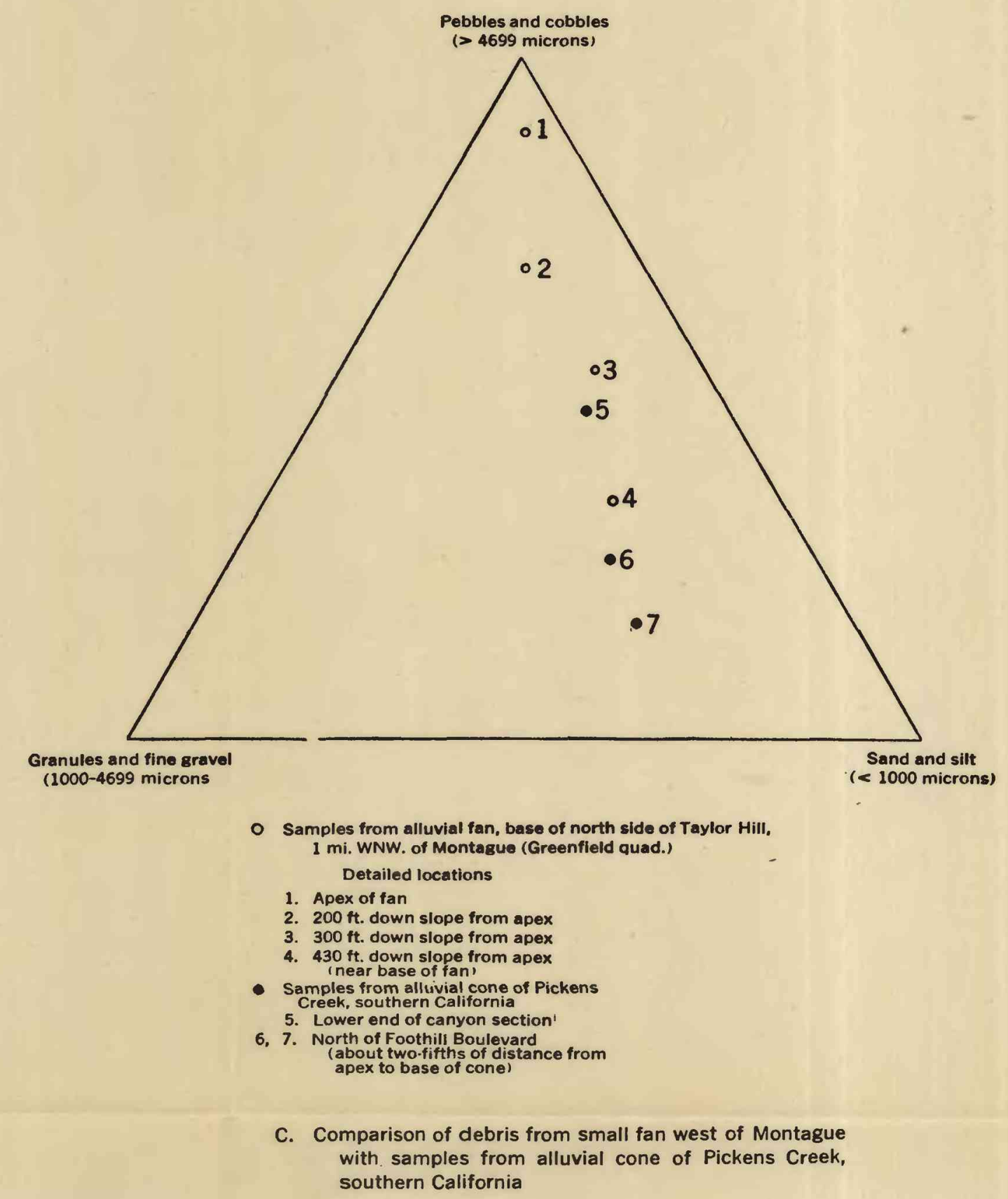

BED-LOAD CHARACTERISTICS OF CERTAIN CONNECTICUT VALLEY STREAMS. 
GEOLOGICAL SURVEY

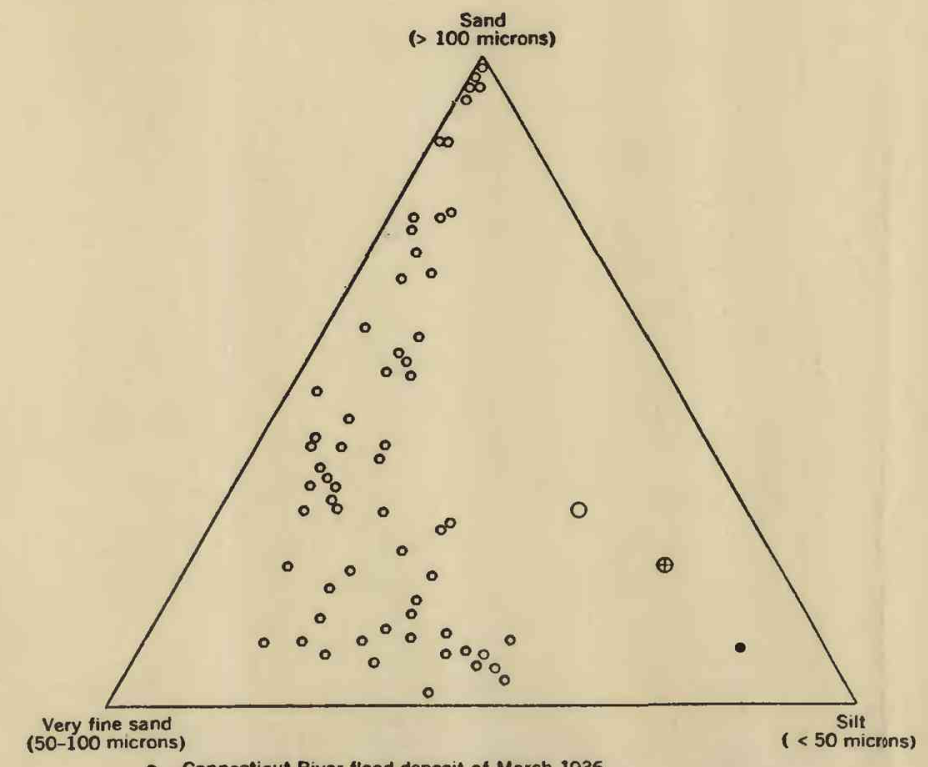

River flood deposit of March 1936

Composite of 12 analyses: coarser deposits, flood of January.-February
1937 , Ohio Valley area (Water-Supply Paper 838, pl. 25, fig. 2., B)

- Composite of 159 analyses; finer-textured deposits, flood of January-February
1937 , Ohio Valley area (Water-Supply Paper 838, pl. 25, fig. 2, A)

Composite of 4 analyses, Potomac River deposits, Seneca quad., Md. Va.
(Water-Supply Paper 838 , pl. 25. iig. 2, C)

A Connecticut River flood sediments of March 1936

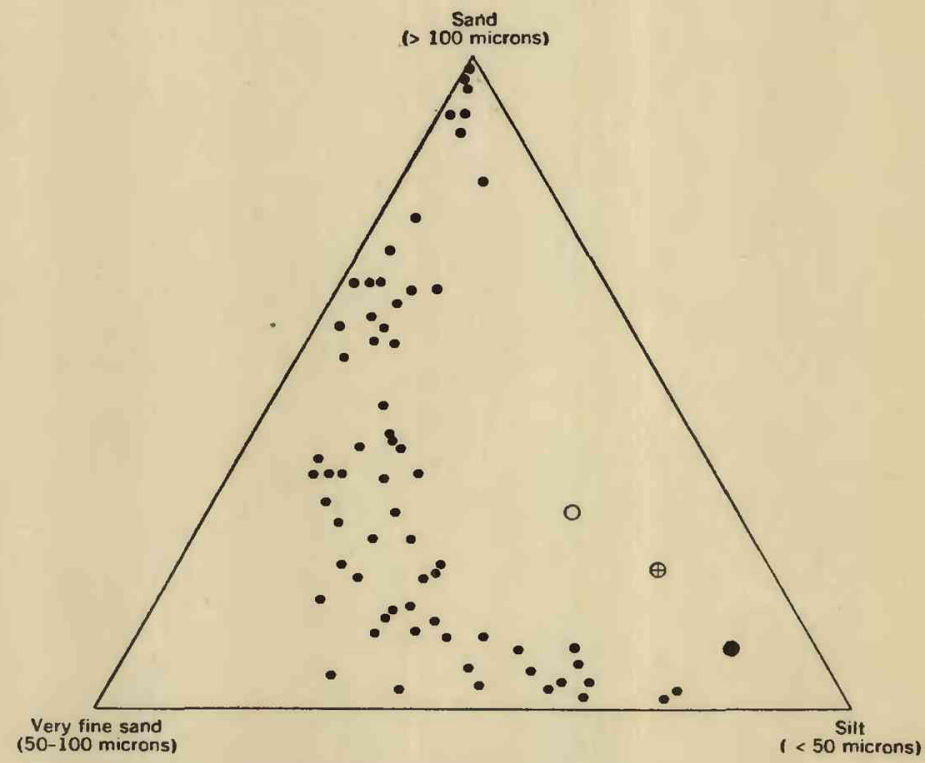

- Connecticut River flood deposit of September 1938

Composite of 12 analyses: coarser deposits. flood of January-February
1937, Ohio Valley area (Water-Supply Paper 838 , pl. 25, fig. 2, B)

- Composite of 159 analyses: finer.-textured deposits, flood of January. February
1937 , Ohio Valley area (Water-Supply Paper 838 , pl. 25, fiz. 2. A)

$\oplus$ Composite of 4 analyses, Potomac River deposits, Seneca quad., Md.va.
(Water-supply Paper 838. pl. 25. fig. 2, C)

B Connecticut River flood sediments of September 1938

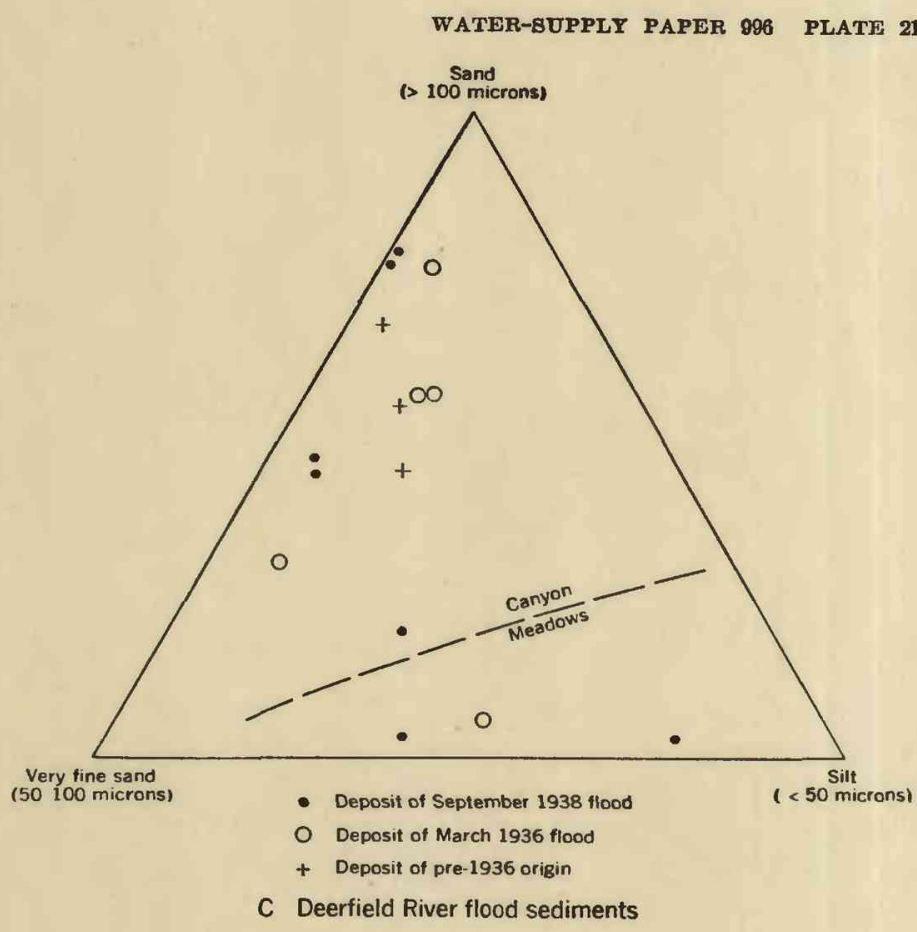

GENERAL CHARACTERISTICS OF RECENT FLOOD DEPOSITS IN THE CONNECTICUT RIVER DRAINAGE BASIN, MASS. 


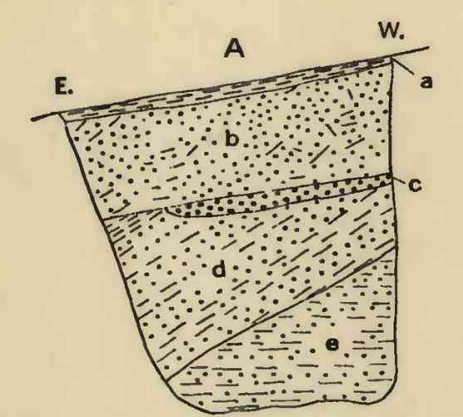

a, 1939 (?) deposit d, 1936 deposits b, 1938 deposits

STATION SN 5

West bank of Connecticut River.
$0.1 \mathrm{mi}$. S. of Ashley Ave. bridge

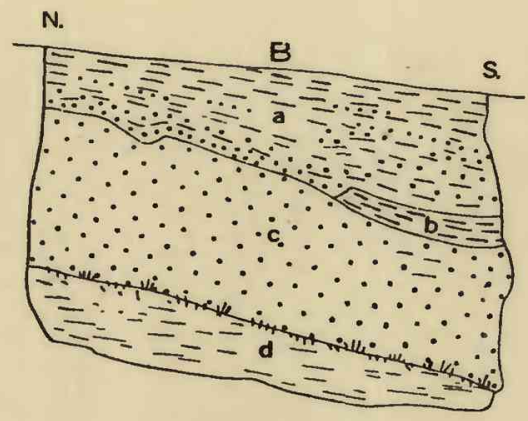

a, 1938 deposits

b. c. 1936 deposits

STATION MH 17

South bank of creek, $30 \mathrm{ft}$. W. Of Hwy.
13 bridge, 1.1 mi. N. of Hadley

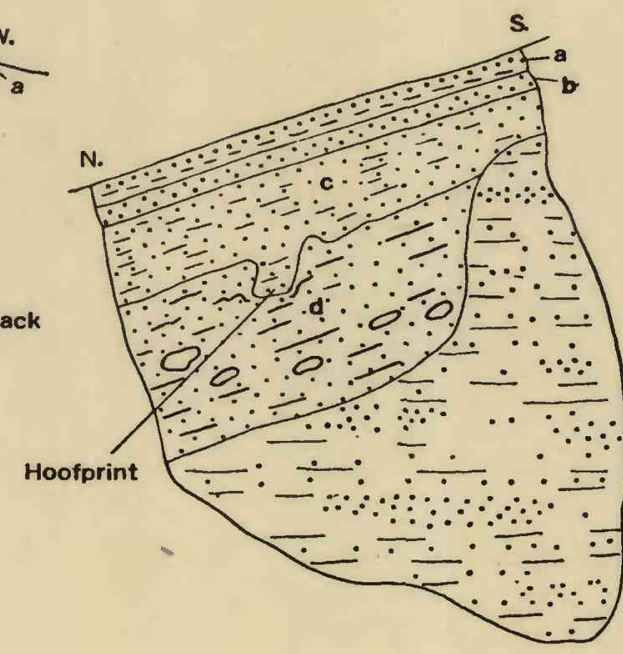

a-c, 1938 deposits

d, 1936 deposits

STATION MT 1

Swirlpit in flood plain, $0.8 \mathrm{mi}$.
NNE. of Hattield

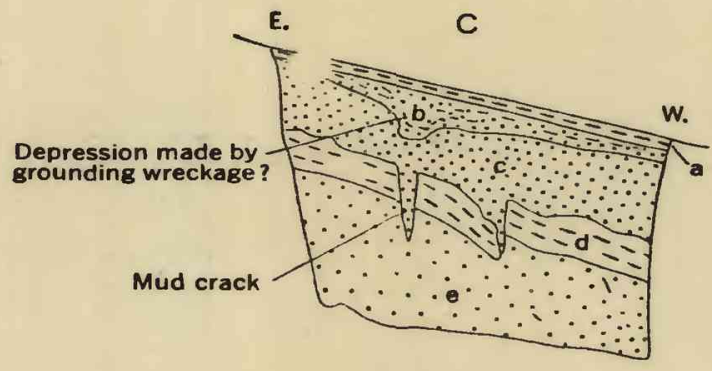

a, 1939 (?) deposit b, c, 1938 deposits

d. e, 1936 deposits

STATION MT 12

Connecticut River bank, SW, corner
of cemeterery. 0.6 mi. SW. of
Sunderland

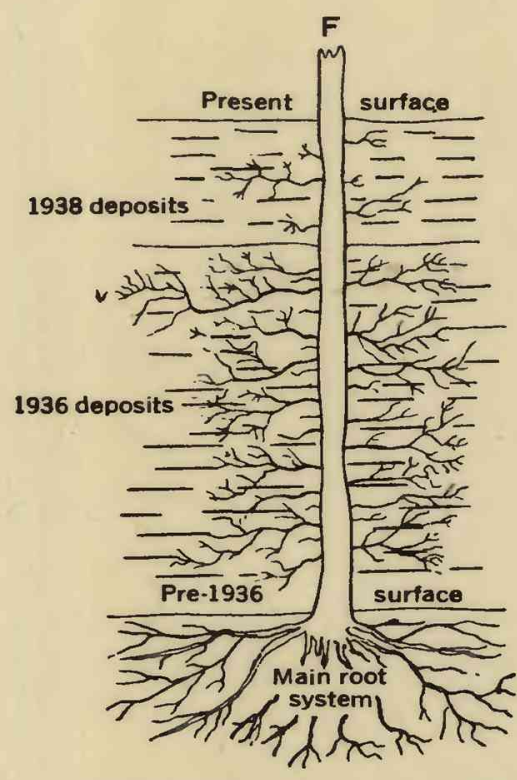

Stalk and roots of small tree, showing
relative development of additional

relative development of addition
rootlets in recent flood deposits

STATION N 15

Inner edge of flood plain, $0.4 \mathrm{mi}$. W.
of Munns Ferry
EXPLANATION
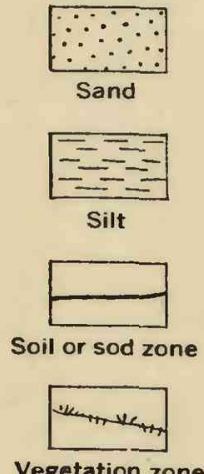

Nature of stratification

shown diagramatically

See text for description

of sections

Horizontal and vertical scale 1

TYPICAL STRUCTURAL CRITERIA FOR DISCRIMINATTON AND INTERPRETATION OF FLOOD DEPOSITS. 

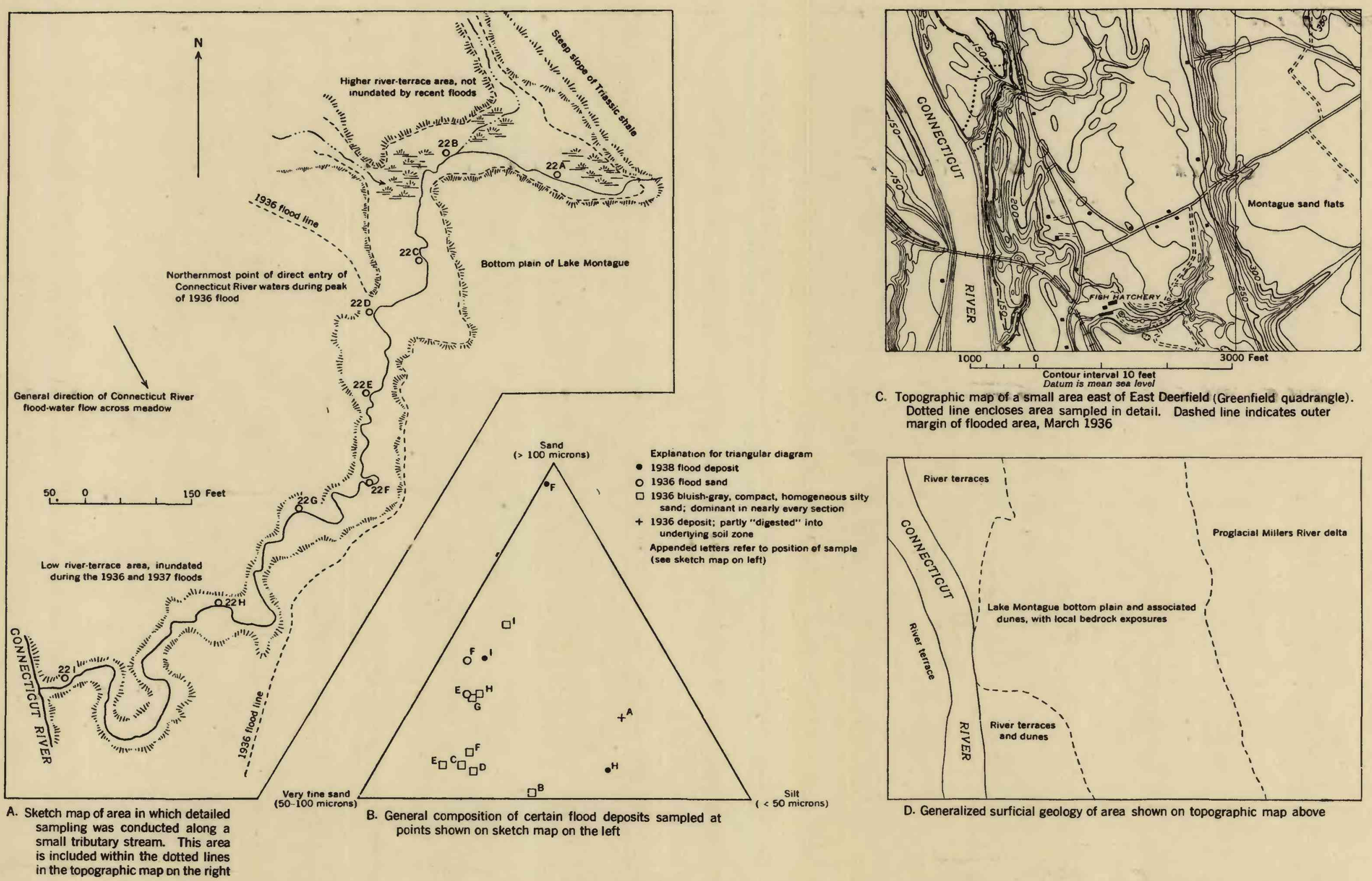

Datum is mean soa level
C. Topographic map of a small area east of East Deerfield (Greenfield quadrangle). Dotted line encloses area sampled in detail. Dashed line indicates outer
margin of flooded area, March 1936

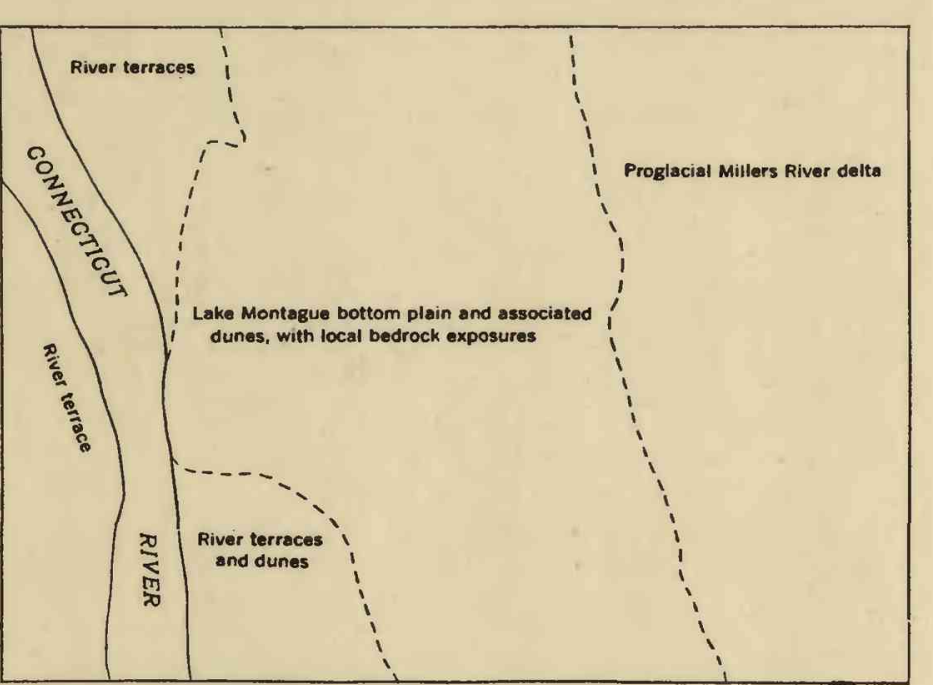

D. Generalized surficial geology of area shown on topographic map above small tributary stream. This are in the topographic map on the right

RELATIONS AND CHARACTERISTICS OF RECENT FLOOD SEDIMENTS IN LOWER PART OF SMALL STREAM EAST OF EAST DEERFIELD. 


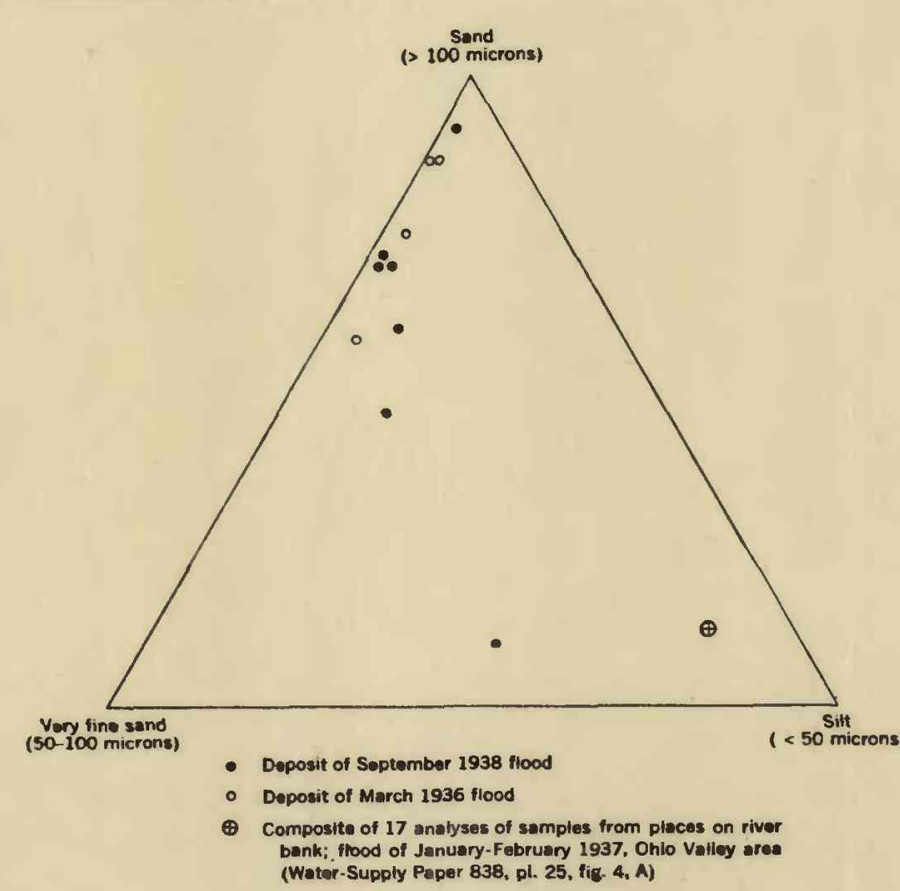

A. River banks of straight or gently curving outline

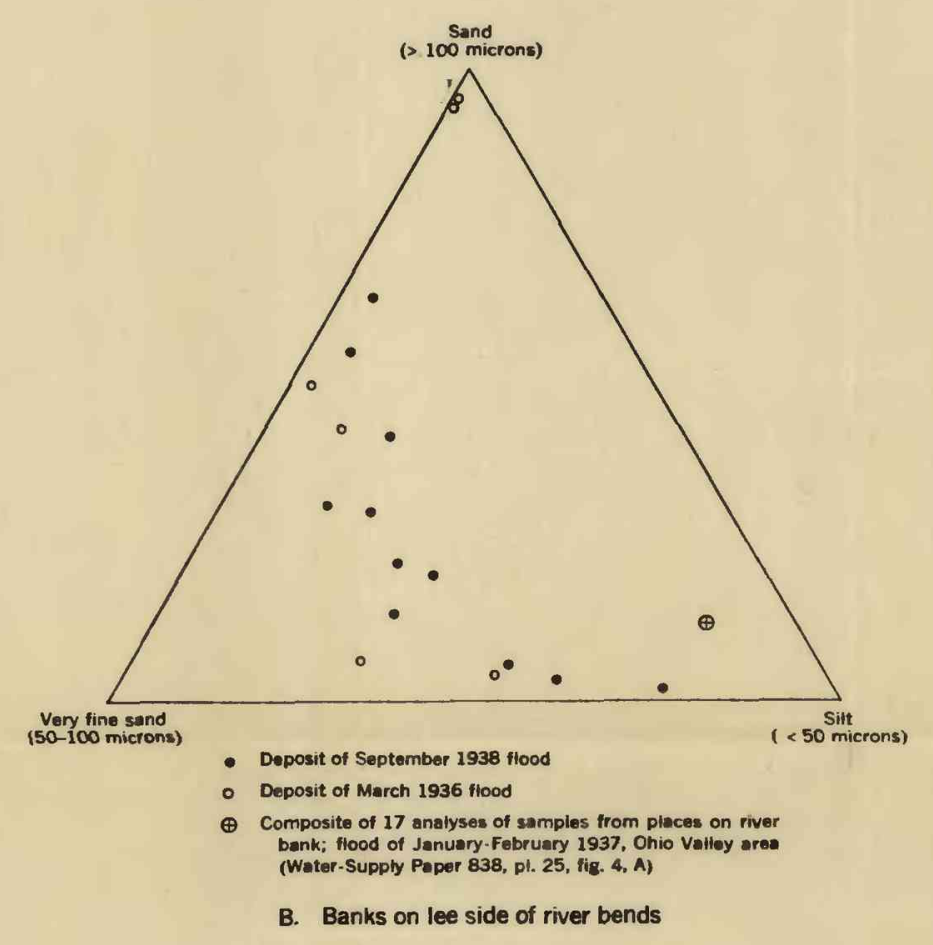

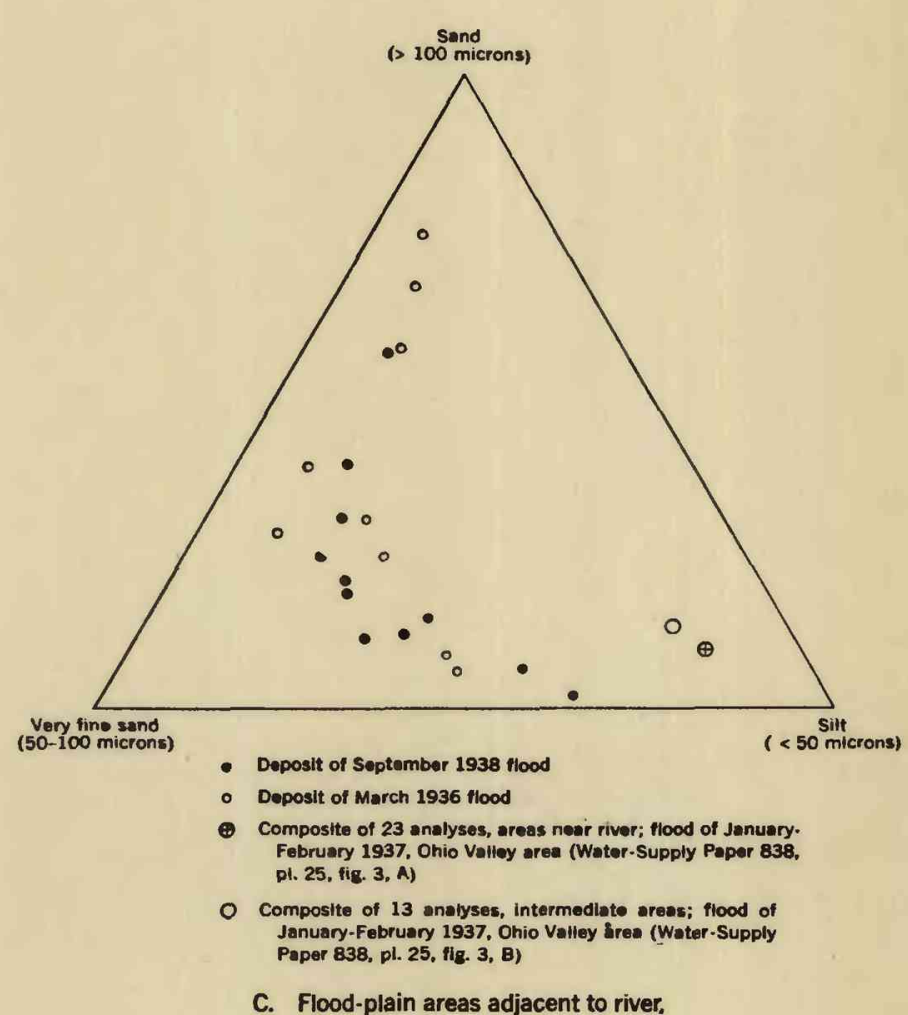

C. Flood-plain areas adjacent to river.

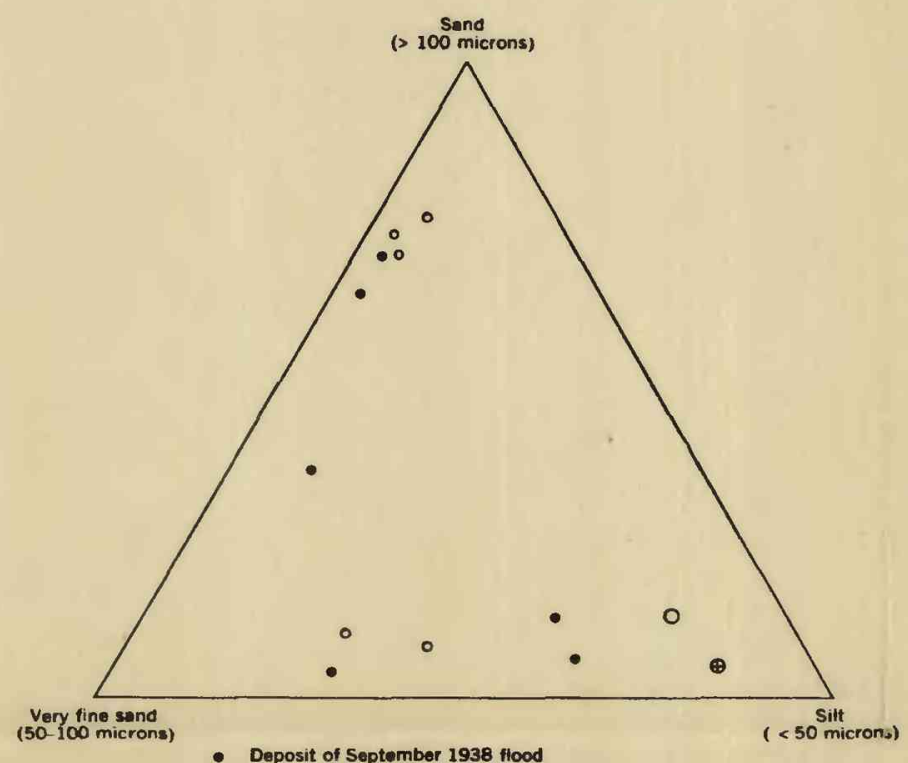

- Deposit of September 1938 flood

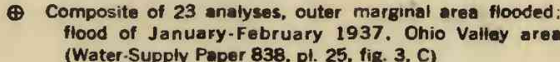

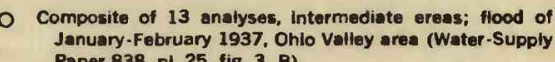
Paper 838, p1. 25, fig. 3.

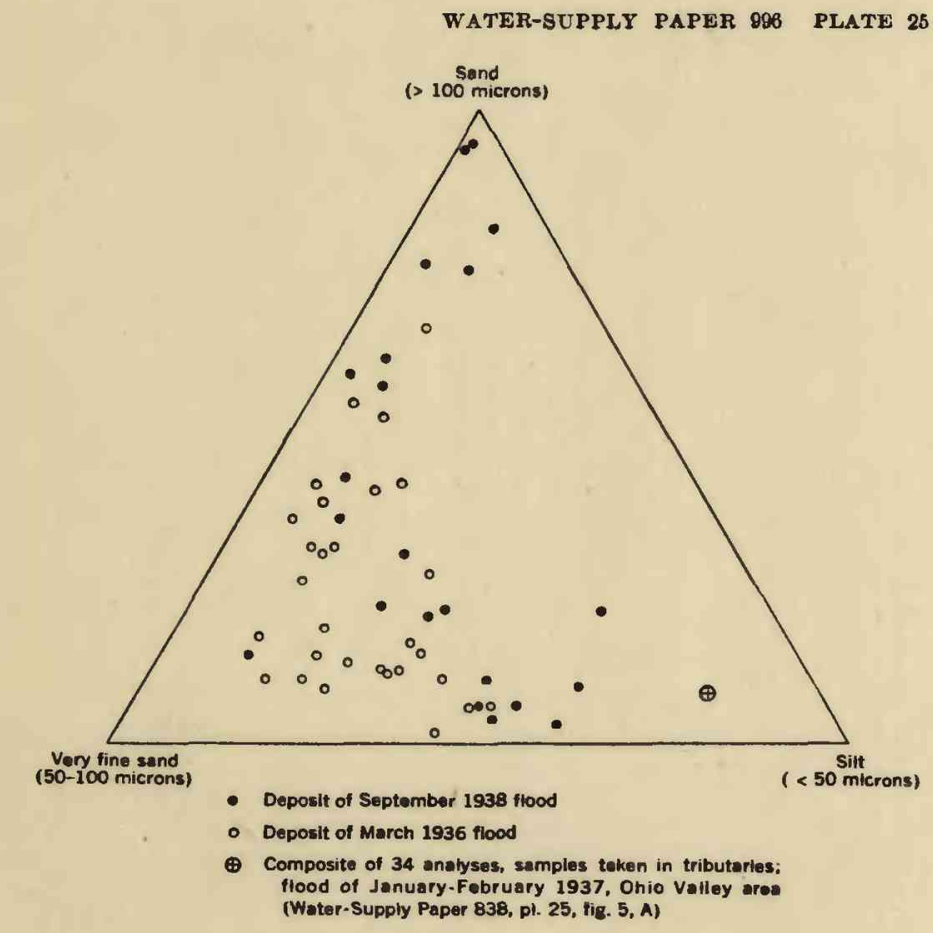

E. Tributary streams at or very near mouths

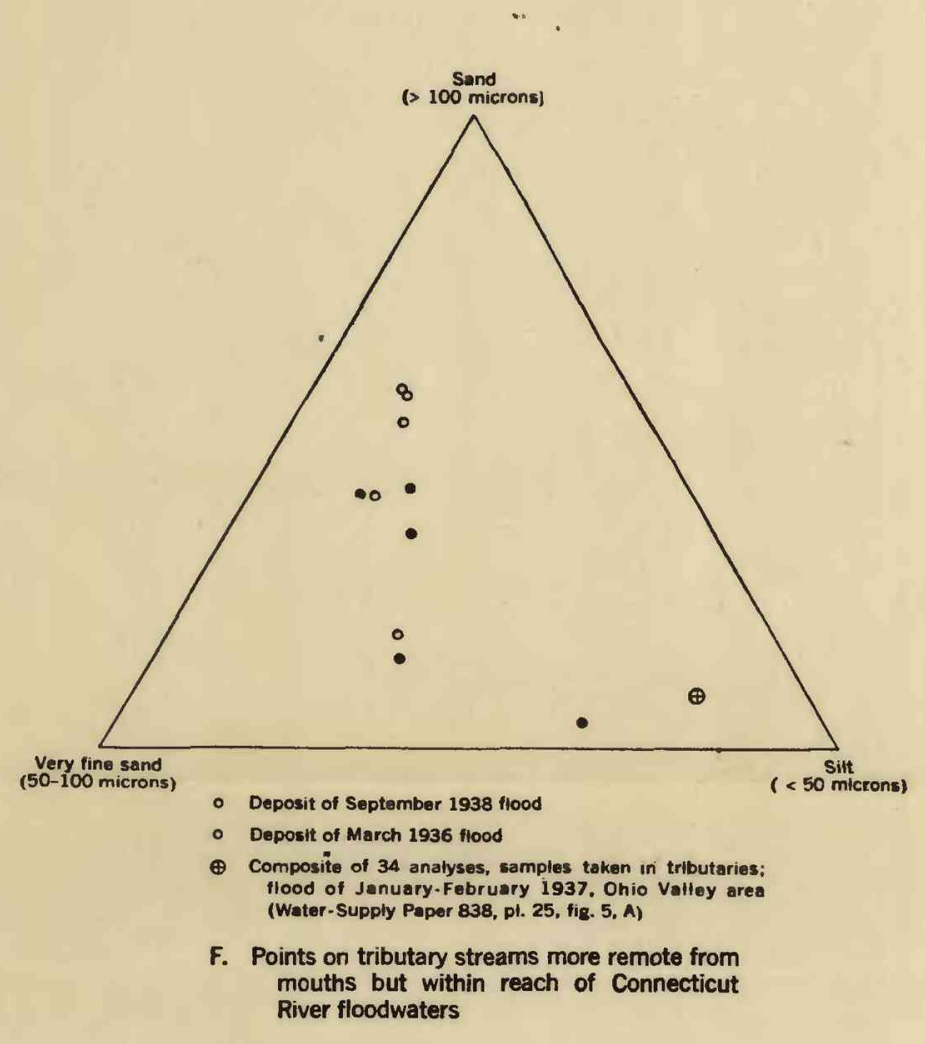

GENERAL CHARACTERISTICS OF RECENT FLOOD SEDIMENTS OF THE CONNECTICUT RIVER IN VARIOUS DEPOSITIONAL ENVIRONMENTS. 


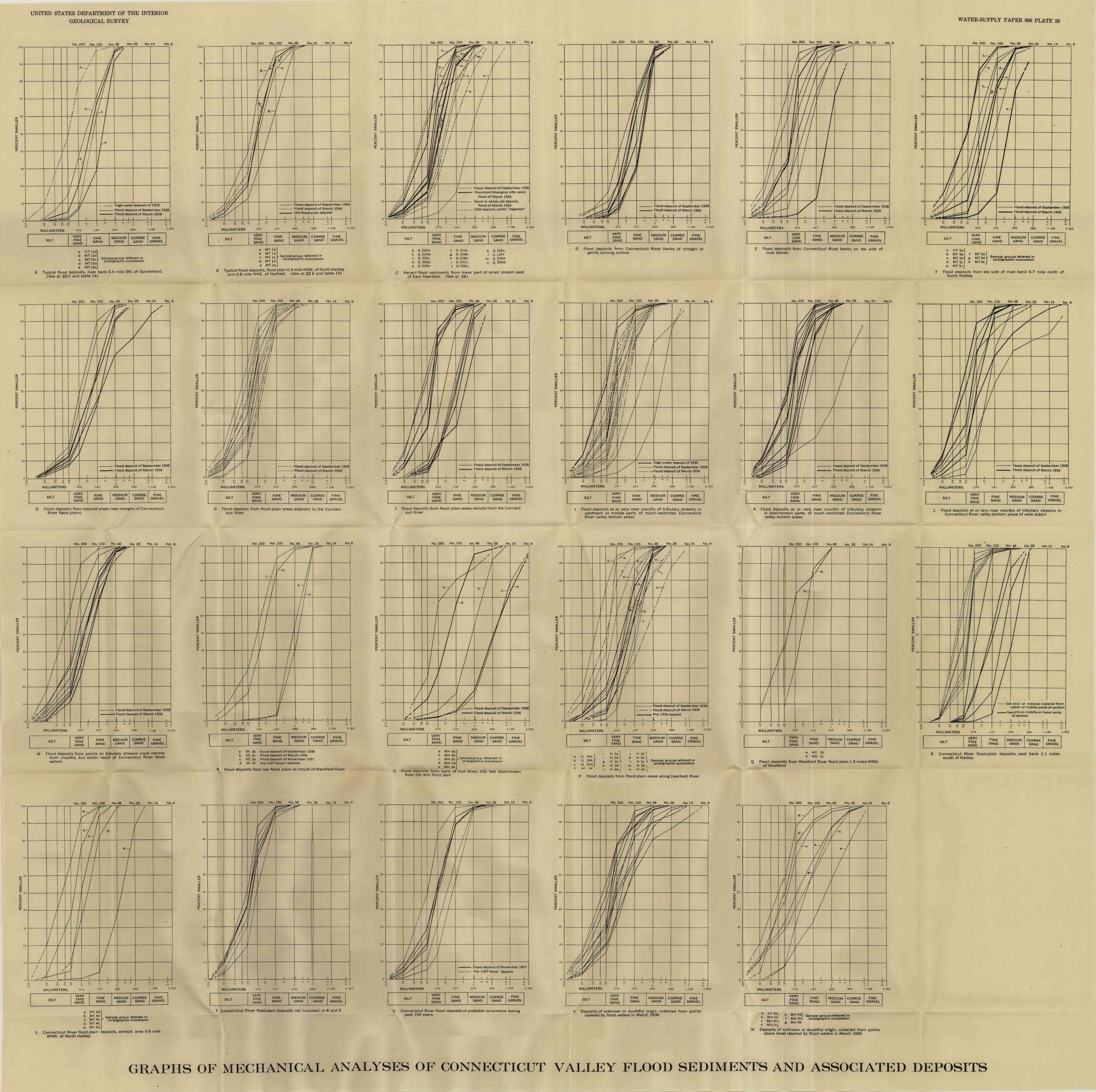



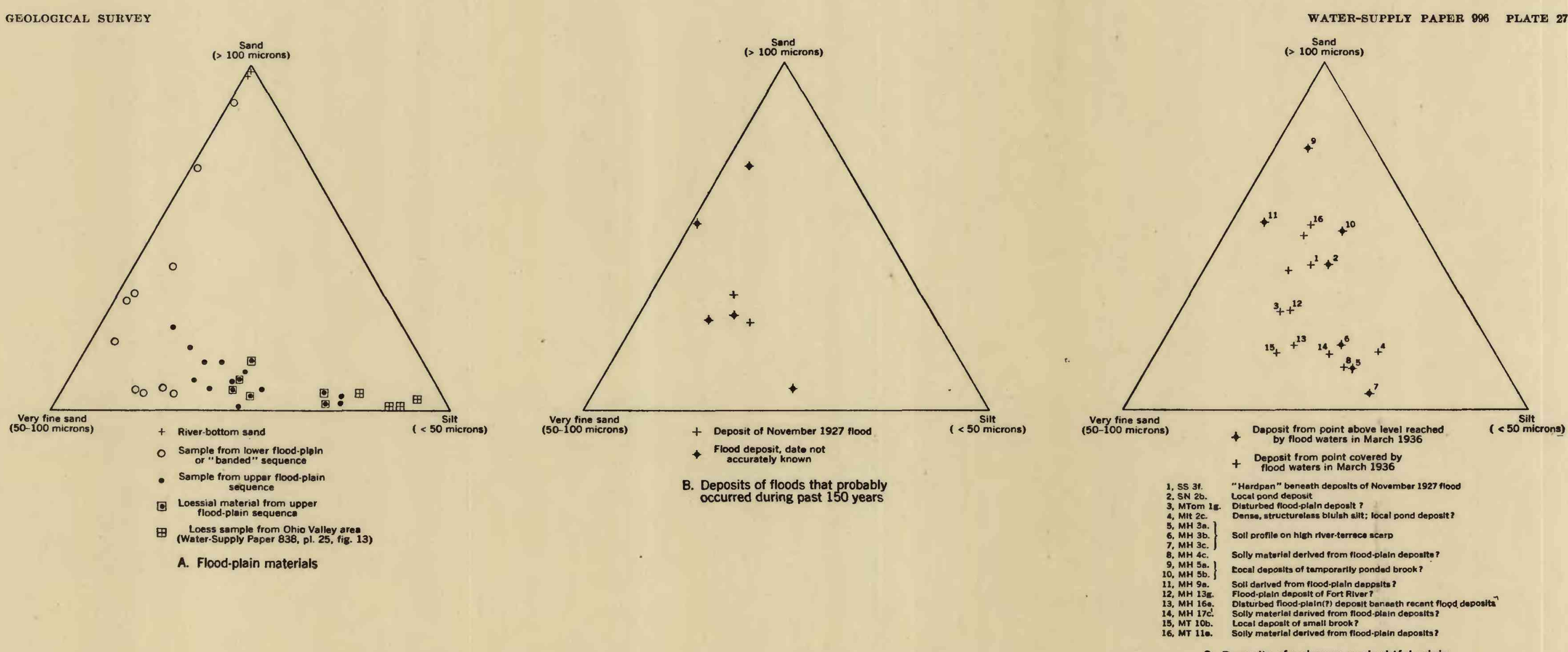

GENERAL CHARACTERISTICS OF CERTAIN PRE-1936 DEPOSITS IN THE CONNECTICUT VALLEY.

C. Deposits of unknown or doubtful origin 

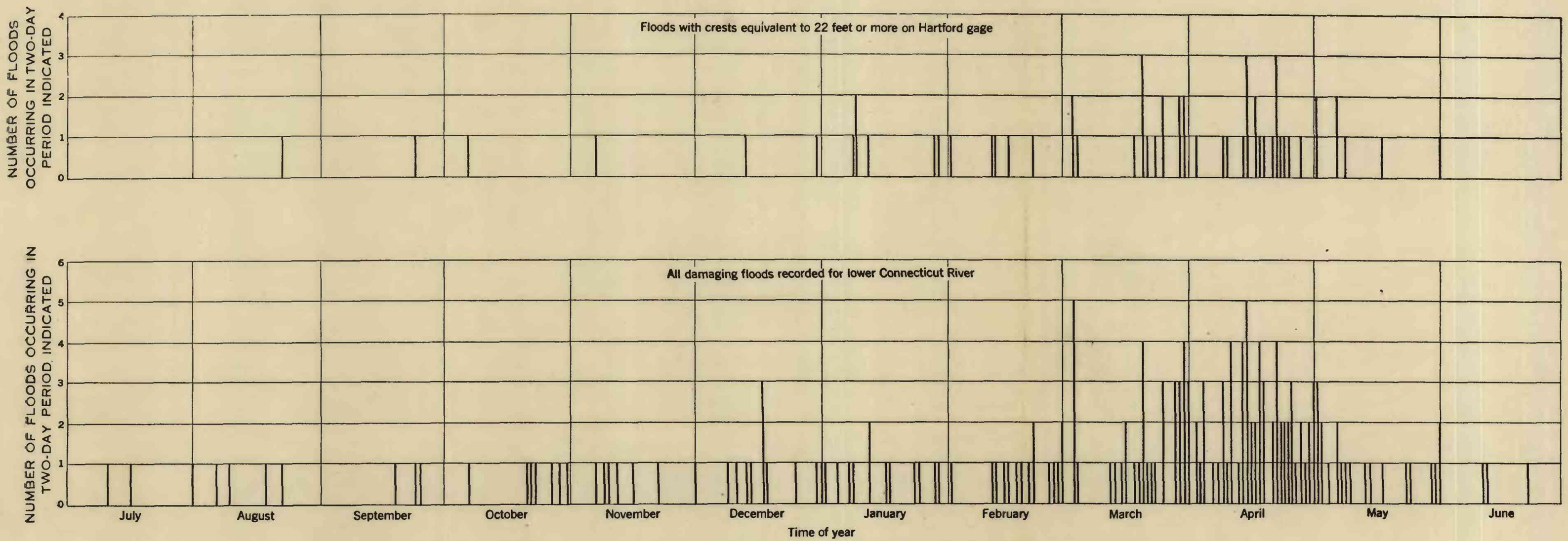

DISTRIBUTION THROUGHOUT THE YEAR OF DAMAGING FLOODS ON THE LOWER CONNECTICUT RIVER. Based on published recorde. See Geological Survey Water-Supply Paper 836-A. 


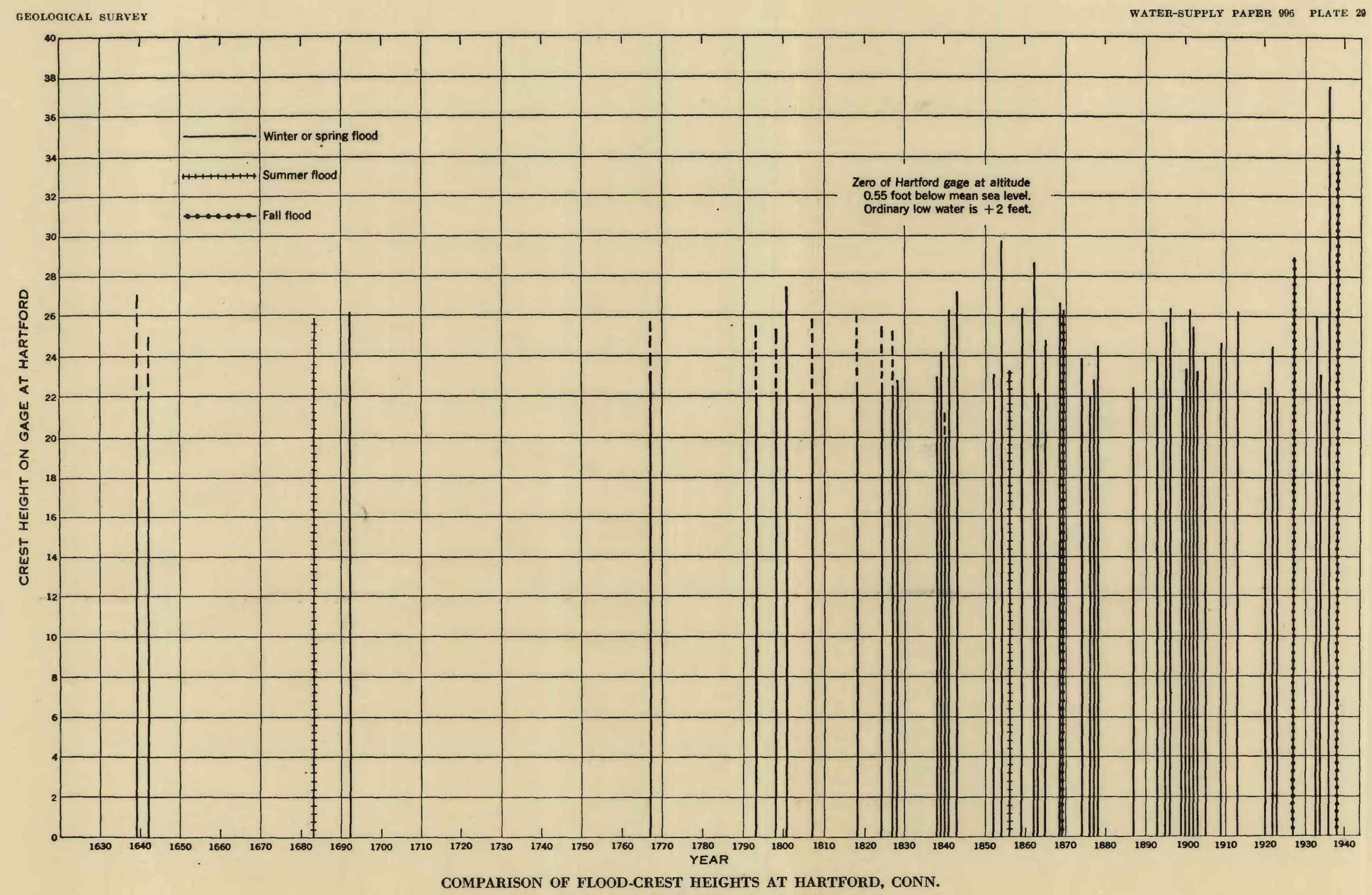
Baeed on public records. See Geological Survey Water-Supply Paper 836-A. 


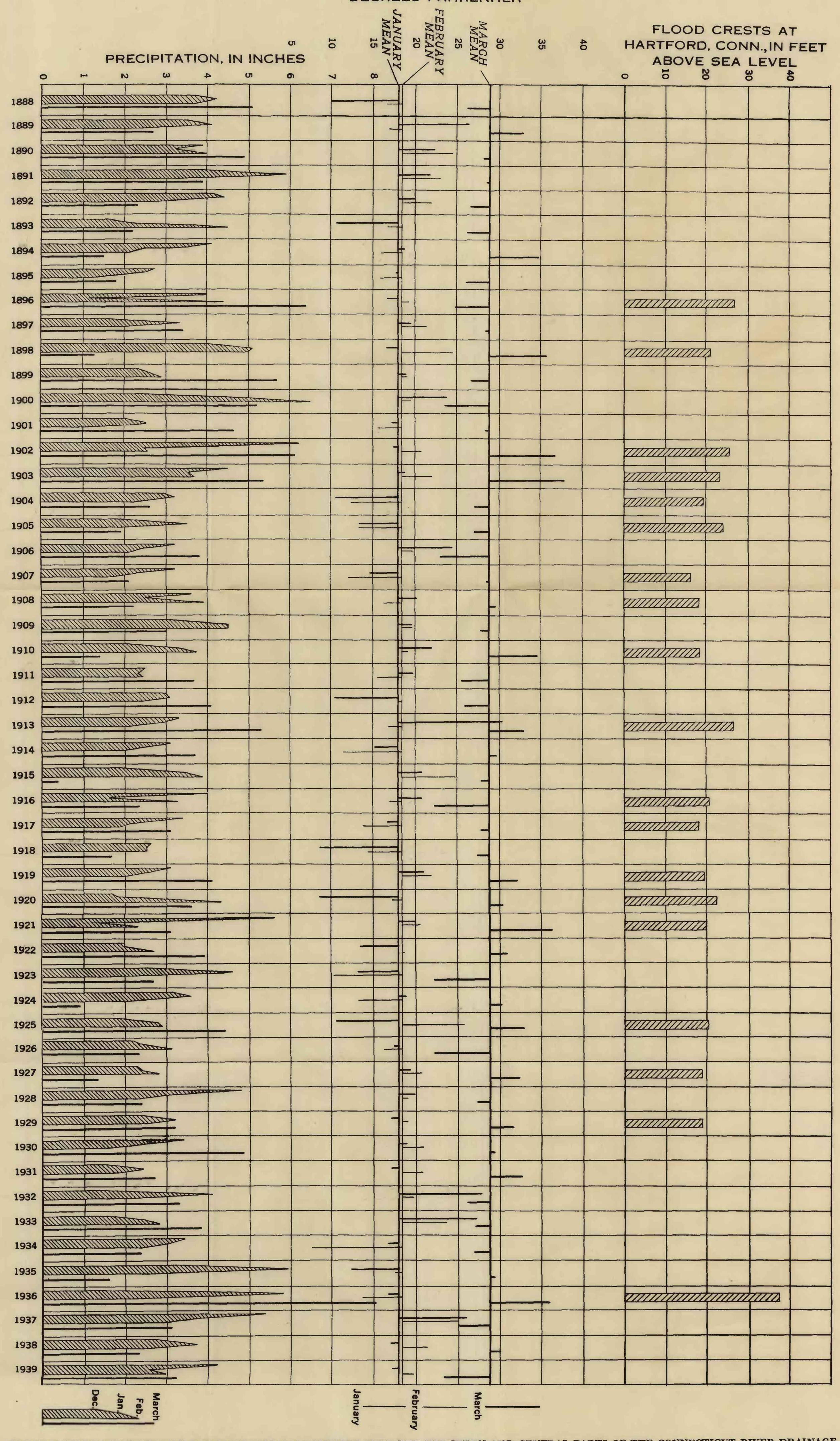

